DFFERSON, and the

UNIVERSITY OF VIRGINIA

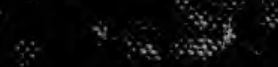

JOHN S. PATTON 


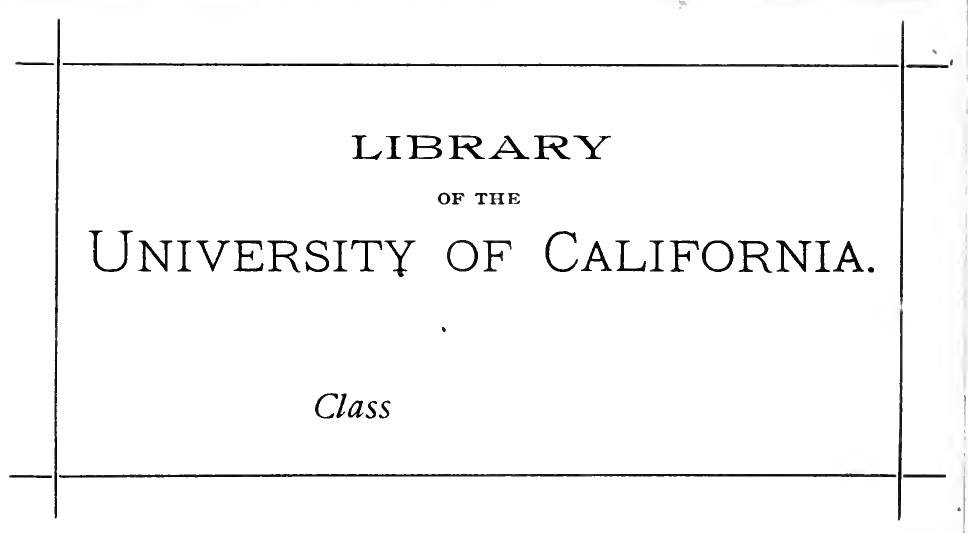



Digitized by the Internet Archive in 2007 with funding from Microsoft Corporation 
JEFFERSON, CABELL, AND THE UNIVERSITY OF VIRGINIA 


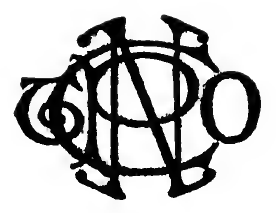




$$
6
$$




$$
0
$$




\title{
JEFFERSON, CABELL
}

\section{AND THE \\ UNIVERSITY OF VIRGINIA}

\author{
BY JOHN S. PATTON
}

Librarian to the University of Virginia

Ce livre est une histoire, et non pas une dissertation.-Michelet.

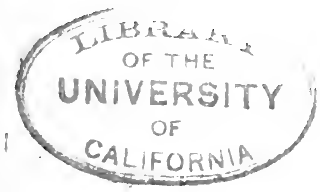

New York and Washington

THE NEALE PUBLISHING COMPANY 1906 


$$
\begin{gathered}
\text { LD } 5678 \\
P 3
\end{gathered}
$$

$$
\text { Copyright, 1906, by }
$$

THE NEALE PUBLISHING COMPANY 
TO BEATRICE 


\section{CONTENTS}

Chapter.

Page.

I. Preliminary Survey-Elucation a Privilege in w 1776-To BE EXTENDED BeYOND CleRgy AND PLANTERS-NECESSARY EDUCATIONAL, Foundatrons LaCKING-JEFFERSON'S IDEALS AND HIS PLANS-LONG WAIT for PopUlar SyMpathy,................

II. The Albemarle Academy-The Central CollegeJEFFERSON INVITED TO ASSIST IN ESTABLISHING AN ACADEMY in CharLotTesville-Becomes a TrusTEE-REPORTS A PLAN LEADING TO A UNIVERSITYJosepr C. CABEIL-THE CENTral COLLEGE CHAR-

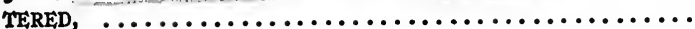

III. The Central Collige-Becomes the UnIVERSITY OF VIRGINIA-LOCAL ANTAGONISMS-STAUNTON AND LEXINGTON-LEGISLATIVE DISCUSSION OF EDDUCATIONAL NEEDS-FIRST VISITORS-SITE OF THE COLLEGE-ARCHITECTURAI PIAN-CoRNERSTONE LAIDRECTOR'S FIRST REPORT AND ITS BOLD BID,.........

IV. The Rockfish Commission-Cabell Fears the INFLUENCE OF STAUNTON AND LEXINGTON-MEMBERS OF THE COMMISSION-JEFFERSON'S LEADERSHIP-THE COMMISSIONERS' REPORT-STRUGGLE RENEWED IN THE LEGISLATURE-CABELL'S FINE MANAGEMENT,...

V. Perilous ANTAgonisms-Cabeil Advises Laying OUt

ALI THE MONEY IN BUIIDING-LOANS FROM THE LiTERARY FUND-HOSTILE EFForTS to ABSORB ITS INCOME-CABEII'S DESIRE TO RETIRE FROM THE SENATE-CRY Against Unitarianism-Rotunda BEGUN-REMISSION OF LOANS FROM THE LITERARY Fund-Proposed Removal, of William aNd Mary - How DEFEATED, .........................

VI. REIigion and State Education-Popular DisconTENT WITH DR. COOPER'S APPOINTMENT-JEFFERSON DEFENDS IT-PlaA FOR RELIGIOUS SEMINARIES NEAR THE UNIVERSITY-BOWDITCH AND TICKNOR-AMERICAN Professors-Francis Walker Gilmer,......

VII. Gilmer's Mission to EUROPE-EFForTS to Procure AMERTCAN PROFESSORS-COMMENTS OF John AdAMS and General BlackBurN-Gilmer ENGages ProFESSORS IN EUROPE-HOMEWARD VOYAGE, .........

VIII. THE FACULTY OF I825-ARRIVAL OF PROFESSORSTHETR RECEPTION IN RICHMOND-MR. JEFFERSON'S WEICOME-BRIEF BIOGRAPHIC INFORMATTON-FIRST WINTER IN VIRGINIA-GLimpSES OF SOCIAL LIFE OF FACULTY AND STUDENTS-AMERTCAN-PROFESSORS,... 
Chapter.

IX. The Law Professorship-Gilmer and THE LaW PROFESSORSHIP-WIRT EILECTED PRESIDENT, AND PROFESSOR OF LAW-JEFFERSON'S DISSENT-WIRT DECIINES-JOHN TAYLOE LOMAX THE FIRST LECTURER IN THE SCHOOL, ....................... IO 8

X. EARLy EFForts at Govern MENT-Scheme of GovernMENT-VARIOUS OFFICERS AND ThEIR DUTTES-JEFFERSON'S THESIS ON STUDENT GOVERNMENT-SOME EXAMPLES OF HIS RULES OR "ENACTMENTS"UNIFORM AND EARLY RISING LAWS-HARVARD PENALTIES-FIRST RIOT-APPEAL, TO THE-VISITORS-JEFFERSON's INDIRECT ANSWER TO A STUDENT PAPER,... II5

XI. "THE COURT OF THE UNIVERSITY"-COURT OF RECORD FOR TRIAL OF STUDENTS-PROFESSOR OF LAW TO BE JUdGe WITH POWERS OF A JUSTICE OF THE PEACEGRAND JURy WITH SOME STUDENT MEMBersProctor to be Sergeant with Power to Command a Posse Comitatis, . ...................... 136

XII. THE WILD DAYS OF OLD-REBELLION OF I833-MEETiNG IN Hotel C-Faculty MeETINGS-STUdENT DeLEgation aNd ITS Mission of DefianCe-ChapLAIN HAMMETT'S Good OFFICES-The MaTTER ENDS LAMELY-REBELLION OF 1836-DEFIANT STUDENT Military-Armed Citizens-SeventTy Students EXPELLED-Chatrman Davis's Defense OF The ACT, I43

XIII. Assassination of Professor Davis-Shot Down IN THE DARK-Story of THE EVENT by a STUDENT of that Day-Suspicion, PURSUIT and ARRESTSTUDENT CO-OPERATION WITH THE OFFICERS OF THE LAW-Simms BaILED-NeVER APPEARED FOR Trial. -More Disorder-ANother ApPEAL TO THE CiviL AUThORITIES-Mr. Rives Proposed a PRESIDENCY FOR THE UNIVERSTTY, .................... I55

XIV. The HoNOR System-STUdent FreEdoM AND RESPONSIBILTTY=TRTVIAL NATURE OF MANY OFFENSES =EXTRACTS FROM THE FAcUlTy MINUTES-SOcial Customs and Their INFLUENCE-Foreign ProFESSORS OUT OF TOUCH-WAVERING LOYALTY TO JEFFERSON'S IDEALS-SPIRIT OF 'HONOR-EVOLVING AN UNWRITTEN CODE, ........................ I66

XV. The JefFersonian Group of Buildings-DelineaTION OF THE GROUNDS-IN SEARCH OF ARCHITECTURAL HINTS-JEFFERSON AND THE ARTS-PALIADIO'S CONTRIBUTTON-SPECIFICATIONS FOR THE CORinthian Capitals-Pantheion as a Model FOR THE Central Buildings-RapHaEL's School of Athens -Later Buildings, ....................... 
Chapter.

Page.

XVI. Military Organizations-The Civit, War-Early MIIITARY SPIRIT - VOLUNTEER COMPANY - DisBANDED FOR INSUBORDINATION- "REBEI" ENTHUSIASM AMONG THE STUDENTS-FIRST FLAG RAISED AND FIRST BloOd SHED-STUdent CoMpanies FORMED-SOUTHERN GUARD-SONS OF LIBERTY"BOYISH RUSH TO DUTY"-HARPER's FERRY-FACUITY AND THE WAR-SHERIDAN'S RAID, ......... I 98

XVII. "For REMEMBRANCE" - CONFEDERATE CEMETERY NEAR THE UNIVERSITY - BubERLS' FINE BRONZE FIGURE OF A CONFEDERATE SOLDIER-LADIES' MEMORIAI. Association, AND THE D. A. R.-MEMORIAL TABLETS-SOUTH'S SUPREME SACRIFICIAL TRIBUTE,.... 220

XVIII. ThE Literary SOcieties-PATrick HENRY SoCIETY-JEFFERSON SOCIETY-ITS HISTORY-MADISON, MONROE AND LAFAYETTE HoNORARY MEMBERS-JEFFERSON DECLINED MEMBERSHIP FOR OFFICIAI. REASONS-WASHINGTON SOCIETY-ITS HISTORY-ANTE BeILUM DeBates-What ITS MiNuTES TeLL OF

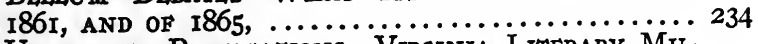

XIX. UNIVERSITY PUBICATIONS-VIRGINIA LITERARY MUSEUM-PROFESSORS DUNGLISON AND TUCKER AS EDITORS-STUDENT PUBLICATIONS-Collegian, University Magazine, Jefferson Monument Magazine, College Topics, Corks and Curls, Annals of Mathematics, Alumni Bulletin, ETC.-NOTES OF SUCCESS AND FAILURE, ........................... 254

XX. ThE General Library-JefFerson's EarLy Plans AND PERFORMANCES-HIS CATALOGUE AND VIEWS UPON WHICH IT WAS BASED-HIS Books-RoTUNDA AND LibRARY DESTroyed BY FIrE-STATUARY, Paintings, and Other Treasures-Notable GathERINGS-BANQUET TO LAFAYETTE-JEFFERSON'S RE-

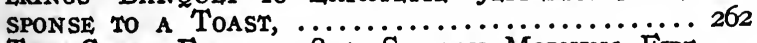

XXI. The Great Fire OF 1895-Sunday MoRning Fire ALARM-EFForTS to SAVE THE ROTUNDA-REMOVAL, OF Galit's Statue of JeFFERSON-PROMPT ACtION OF FACULTY AND VISITORS-No SUSPENSION OF WORK-MEANS SOON AT COMMAND-RESTORATION and Expansion-Lawn BuILDINGS aNd TheIr OCCUPANTS-PROCTOR'S OFFICE AND THE POSTOFFICE,.. 278

XXII. ATHLETICS AT THE UNIVERSITY-JEFFERSON'S VIEW OF THE PURPOSES OF GYMNASTICS-SCOPE FIXED BY HIM UNEXCEEDED-FACULTY ENCOURAGEMENTD'ALFONCE'S SCHOOL OF EXERCISE-COMING OF BASEBALL AND FOOTBALL-BOATING-FIELD ATHLETICS-TrAck RECORDS-FAYERWEATHER GYMNA- 
Chapter.

SIUM-Indoor Sports-Proposed Athletic ClubHouse, $\ldots \ldots \ldots \ldots \ldots \ldots \ldots \ldots \ldots \ldots \ldots \ldots . \ldots . \ldots . \ldots . \ldots 294$

XXIII. OTHER STUDENT ACTIVITIES-SOCIAL AND ClUB SIDE OF LIFE-GREEK LETTER FRATERNITIES-CLUBS and Organizations-"Hot Feet"-Old Time Dyke -DECLINE OF "FINAL" FESTIVITIES-EASTER WEEK THE MERRY Time, ........................ 306

XXIV. Reiligious Activities-No Compulsion in ReitgIOUS OBSERVANCES-PROFESSORS AND OfFICERS ARRANGED FOR SERVICES AT THE UNIVERSITY-INSTITUTION OF THE Chaplaincy-General. SeCretaryship OF THE Y. M. C. A.-ReLigious WORK FOR THE STUDENTS AND BY THEM-MAdISON HaLI, ......... 3I5

XXV. The Alumni Association-Founded in I838First OfFicers aNd ORATORS-CharTERED IN I873, AND Again in I903-ITS PURPoSES AND GROWTH,.. 321

XXVI. THE SchOOLS FROM I825 TO 1905-PRINCIPLE OF INDEPENDENT SCHOOLS-PROFESSORS INDIVIDUALLY RESPONSIBLE-EXAMINATIONS AND HONORS-TITLED AND UNTITLED DEGREES-ChANGES IN THE ScHOOLS -SUCCESSION OF PROFESSORS, ................ 325

XXVII. The BeggnNing of aN ERA-NeW Educational, Departure-Unusual, Features, Many of Them ADOPTED BY OTHER INSTITUTIONS-ChaNGes, PARTICULARLY IN FORM OF GOVERN MENT-WHAT THEY MEAN, aNd Why They Were Made-IMMediaTe, EFFECT-LOOKING FoRWARD, $\ldots \ldots \ldots \ldots \ldots \ldots \ldots, 346$

\section{APPENDIX.}

I. THE UNIVERSity OF Virginia AND THE CONFEDERACY, . 354 II. HoNORS IN THE JeFFERSON LITERARY SocietY,...... 360 III. HONORS IN THE WASHINGTON LITERARY SOCIETY,.... 364 IV. Magazine Medalists, $\ldots \ldots \ldots \ldots \ldots \ldots \ldots \ldots \ldots . . \ldots \ldots$

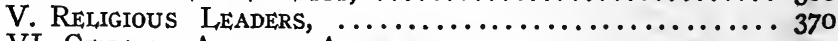

VI. General Alumni Association, $\ldots \ldots \ldots \ldots \ldots \ldots \ldots . . \ldots \ldots$

VII. Chairman of THE Faculty,$\ldots \ldots \ldots \ldots \ldots \ldots \ldots \ldots \ldots \ldots \ldots \ldots \ldots \ldots$ 


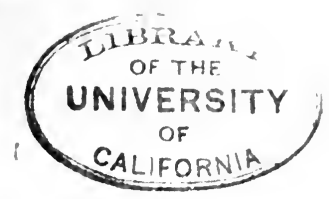

\section{CHAPTER I}

\section{PREIAIMINARY SURVEY}

Education A Privilege in 1776-To be ExTended Beyond CIERGY AND PLANTERS-NECESSARY EDUCATIONAI Foundations Lacking-JefFerson's IdeALS AND HIS Plans-Long Wait for Popular Sympathy.

Until the dawn of the eighteenth century education in Virginia was a special privilege. It was for clergymen and gentlemen,--distinct, as elements,while the sons of the common people, a term then in frequent use, were well enough employed in making tobacco. The planter who had Madeira in his cellar almost certainly had a tutor in his library for the intellectual behoof of his children; or he sent his sons to Princeton or to the universities of the mother country. The offspring of less fortunate folk grew up in an atmosphere in which $\mathrm{Ma}$ deira, the clergy, and the pedagogue were little known.

The Revolution sent the thrill of a new life through the country. The value of the yeomanry in that war was evident, and gratefully appreciated. Its share in the tremendous development of this new world - for it was still new, and its possibilities not more than suspected-was seen to be of the first importance, and it was equally obvious that men whose fathers had worn buckskin or jeans would exercise in the government an influence in some measure proportioned to their numbers. The day of royal governors and councils, shirted in Mechlin lace and frills, with powder on hair, was past. The 
wiser men-the seers of their generation-knew that the influence that was to control was less aristocratic descent than democratic ascent; that in the era then dawning men would rise, not descend, to the discharge of the high responsibilities of citizenship, and that enlightenment would be the one certain safeguard of the sacred things of liberty.

Thus education was confessed to be better than an accomplishment for gentlemen and more than a preparation for holy orders; it was to be at once the shield and weapon of the new order of republican knighthood. The sons of the people were to be educated in primary and preparatory schools, and the best of them in colleges in which the arts and sciences-especially the sciences-were taught by the most eminent scholars. Where was this to be accomplished? There were no schools in Virginia at all competent to confer this great blessing on the thousands of young Americans who were growing up in the dense ignorance which was their certain heritage.

There was William and Mary, founded nearly a hundred years before the Revolution, in order that the church of Virginia might be furnished with a seminary of ministers of the Gospel, that the youth might be "piously educated in good letters and manners, and that the Christian faith might be propagated amongst the Western Indians." " Aristocracy, philanthropy, and the Establishment joined hands and left no place for the sons of the soil. But public sentiment no longer supported an overweening anxiety for the souls of "the Western Indians." In so far as social relations were concerned

${ }^{1}$ Charter of William and Mary. 
this sentiment was still pro-aristocratic, but in church affairs it had advanced to the point of readiness for a statute for religious freedom. There is no ground for wonder that dissatisfaction with a college which was a part of the government and avowedly a Church of England seminary had developed rapidly. The first effective dissent was made by the churches outside of the state religion. In Prince Edward County, as early as 1776, Hampden-Sidney had its beginning under the influence of the Presbyterian denomination. Six years later Liberty Hall, a Presbyterian academy at Lexington, under the first charter granted by the new Commonwealth of Virginia, was the beginning of Washington College, now Washington and Lee University. The Baptists and Methodists, under the same impulse, engaged in educational enterprises for denominational reasons. The church-and-state school, as a controlling influence, gave way to the religious college-which was not at all the thing demanded by the times, the education of the masses for the new citizenship.

Thomas Jefferson breathed the new atmosphere, and, unconsciously perhaps, became the best living exponent and defender of the ideas of the new man in Virginia in the middle of the eighteenth century. As a student at Williamsburg-a member of the social set that surrounded Governor Fauquier-he was occasionally, perhaps often, a listener to the debates in the House of Burgesses at the time that body was growing defiant of the King. He was present at the sitting when the resolutions against the Stamp Act were under consideration, when the "torrents of sublime eloquence from Henry" weakened the hitherto supreme leadership of such men 
as Peyton Randolph, Bland, Edmund Pendleton, and George Wythe.

These constituted the old set. A dozen years later this young man who stood "at the door of communication between the House and the lobby" during this "most bloody" debate, as he described it a half century after, had become the leader of the new, and with two men of the old set-Wythe and Edmund Randolph-was appointed by the General Assembly to the task of a general revision of the laws. The representative of the young democracy proposed three bills in the interest of popular education. The plan, as Jefferson wrote in his Autobiography, was, first, elementary schools for all children generally, rich and poor; second, colleges for a middle degree of instruction calculated for the common purposes of life; and, third, an ultimate grade of teaching the sciences generally and in their highest degree. The preamble is a compend of a phase of his political philosophy. "Whereas, it appeareth," so runs the ample syllogism, "that however certain forms of government are better calculated than others to protect individuals in the free exercise of their natural rights, and are at the same time themselves better guarded against degeneracy, yet experience hath shown that even under the best forms those entrusted with power have in time, and by slow operations, perverted it into tyranny; and it is believed that the most effectual means of preventing this would be to illuminate, as far as practicable, the minds of the people at large, and more especially to give them knowledge of those facts which history exhibiteth, that, possessed thereby of the experience of other ages and countries, they may be enabled to know ambition under all its 
shapes, and prompt to exert their natural powers to defeat its purposes; and whereas it is generally true that the people will be happiest whose laws are best, and are best administered, and that laws will be wisely formed and honestly administered in proportion as those who form and administer them are wise and honest; whence it becomes expedient, for promoting the public happiness, that those persons whom nature hath endowed with genius and virtue should be rendered, by liberal education, worthy to receive, and able to guard the sacred deposit of the rights and liberties of their fellow citizens, and that they should be called to the charge without regard to wealth, birth, or other accidental condition or circumstance. But the indigence of the greater number disabling them from so educating at their own expense those of their children whom nature hath fitly formed and disposed to become useful instruments of the public, it is better that such should be sought for and educated at the common expense of all than the happiness of all should be con-

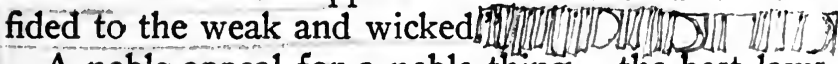

A noble appeal for a noble thing,- the best laws. under the best administration, for the attainment of the happiness of the people.

The bill died a lingering death. Five years it was comatose in the original manuscript. Then it was revived by printing. Fifteen years later (I796) the General Assembly amended it to death by a provision that the inauguration of these schools for the common people should be left to the agency of the county courts.

It was long to wait, but there was a glorious resurrection in less than a century, and the common 
schools are with us as the fruitful triumph of Jefferson's spirit over legislative assassination.

More than one influence had plastic force in this achievement. While Jefferson the student at Williamsburg was taking into the fibre of his nature and intellect the strength of the new thought and feeling, and complying with its tendency as determined by Henry and other whiggish leaders of the time, he was also the subject of a formative force exercised by Dr. William Small of Scotland, a professor of mathematics and philosophy. This worthy gentleman became much attached to the youth from "the up country" and made him his daily companion out of school. From his conversation the young political philosopher got his "first views of the expansion of science, and of the system of things in which we are placed," and yielded to the dominance of ideals to which, sixty years after, he attributed the determination of the destinies of his life.

Urged by Henry toward the activities of the patriot statesman and by Small toward "the useful branches of science," Jefferson entered upon a career in which he united statecraft and love of science for service to his country in preparing the way for an educated citizenship as the only sure bulwark of republican institutions.

This way lay through a people's college supported and nourished by public primary and grammar schools. The young alumnus attempted to shape his alma mater to this service. His bill proposed to enlarge "its sphere of science, and to make it in fact a university." ${ }^{2}$ It did not pass, but in 1799

${ }^{2}$ Autobiography. 
he was made a member of the Board of Visitors of that college and had the two professorships of divinity and Oriental languages abolished and established in their places "a professorship of law and police, one of anatomy, medicine, and chemistry, and one of modern languages." Before he had finished his reforms the law of nature and nations and the fine arts had been added to the duties of the moral professor. But so far as meeting the educational needs of the times was concerned he had failed of significant results, as the Rev. James Blair, its founder, had failed a hundred years before, and his attempt to convert William and Mary into the university of the State was never renewed.

A very casual survey of conditions shows that while the period of the Revolution was one of awakening, especially to the supreme need of popular education, Jefferson was far in advance of his times. Public free schools were not yet possible, and even this strong man could not at that day convert William and Mary into a university such as the age required. He had to wait until the times were propitious for his reforms. In the mean time he had much to do in other fields, and many years elapsed before he had again the leisure to take up his hobby of popular education. By that time he had become known to the uttermost ends of the earth as statesman, scholar, thinker, and had served his day and his country as Governor, Minister to France, Vice-President and as President of the United States. But in the bill of 1776 was the germ of the university of the State. That much Jefferson knew, although not where the institution would be seated, and knew it so consciously that he 
never lost sight of it, no matter where his activities took him. He wrote to Mr. Priestly: "We wish to establish in the upper country, and more centrally for the State, an university on a plan so broad and liberal and modern as to be worth patronizing with the public support, and be a temptation to the youth of other States to come and drink of the cup of knowledge, and fraternize with us. The first step is to obtain a good plan; that is, a judicious selection of the sciences, and a practical grouping of some of them together, and ramifying of others, so as to adapt the professorships to our uses and our means. In an institution meant chiefly for use some branches of science formerly esteemed, may be now omitted; so may others now valued in Europe, but useless to us for ages to come."

This was written in $\mathrm{I} 800$. 


\section{CHAPTER II}

THE ALBEMARLE ACADEMY-THE CENTRAL COLLEGE

JeFFERSon INVITED to Assist in Establishing an ACAdEMy in Charlottesville-Becomes a TrusteE-RePorts a Plan Leading to a University-Joseph C. CabeliThe Central, College Chartered.

Mr. Jefferson returned to Monticello in 1809 , after an almost constant absence of twenty-nine years, during which he had taken the pre-eminent place among the great men of his time which has always been accorded him. The homage of the world folowed him in his retirement.

His withdrawal from official participation in the political affairs of the world, in which he could have remained a commanding figure to the end, did not lead to "the domestic and literary leisure" for which his friend Joseph C. Cabell expressed a strong wish. The seventeen remaining years were filled with unremitting labors for "the better diffusion of knowledge" in Virginia.

As he had ridden away from his home in the year I783, on his way to Annapolis to take his seat in Congress, some of his neighbors asked him to engage, at Princeton, a tutor "of the Irish nation" for a grammar school they had in contemplation. This village academy had not been realized when he returned, twenty-six years later. The letter he wrote from Annapolis to say that he could not employ the tutor either at Princeton or in Philadelphia is the only known contemporary reference to it from 1783 
to 1803 -twenty years. In the latter year it was chartered by the legislature, and then ensued another period of inert existence, which ended on the 25th of March, I8I4. It so happened that on that day John Harris, John Nicholas, John Kelley, Peter Carr, and John Carr, five of the ten trustees named in the charter, were at the Stone Tavern in the village of Charlottesville, discussing, as doubtless some of them had done often in the past score of years, the chances of the successful and profitable establishment of the academy.

Mr. Jefferson appeared in the street before the tavern just at this opportune time, and was invited to take part in the conference, whose object was explained to him. He had written to Dr. Priestly in I80o that he had in view a university "in the upper country." This first direct reference to the point at which he contemplated erecting the central foundation of his system of public schools indicated Charlottesville as the site. And with this great thing in contemplation for the little town, he heard his neighbors on the subject of the academy they hoped to place in "the house of Triplett T. Estes."

f Mr. Jefferson advised the trustees to abandon their small scheme for a large one-a college where the sciences could be taught in "a high degree"and the first step, he told them, was to reorganize their board. Whether these good and true citizens of Albemarle took in the full meaning of the philosopher's plan, or could have grasped it if he had explained it to them as succinctly as he did in his letter of a few days later to Peter Carr, may be doubted, for nothing so thoroughgoing in educational ways had been previously proposed in America, or, indeed, elsewhere; but they deferred to him by filling 
the vacancies in their board, and he was made a trustee, and accepted the office.

The reorganized board convened on April 5, with nearly all the members present. Mr. Jefferson, always a good horseman, rode down from Monticello, a tall, hale man of seventy-one. Peter Carr arrived from Carrsbrook, and was made president of the trustees, while John Carr walked in from Belmont, on the eastern margin of the village, and was voted into the office of secretary. They were soon absorbed in the business before them, those lawyers, clerks of court, merchants, physicians, land owners, and what not. Four other meetings followed-the last, as far as any record exists, on the Igth of August, I8I4. From that date adjournment was taken to the third Friday in November.

The minutes of these several meetings give a very brief history of the genesis of Albemarle Academy, important as a starting point for the story of a great movement. At the very beginning of their deliberations Thomas Jefferson, Peter Carr, Frank Carr, John Nicholas, and Alexander Garrett were chosen as a committee "to draft rules and regulations for the government of the proposed institution," and were also instructed "to report to the next meeting a plan for raising funds for the erection and support of the said institution."

A lottery was decided on as a means of raising funds, under the act of January I2, I803, and a board consisting of John Winn, John Kelley, James Leitch, Frank Carr, and Alexander Garrett was elected to manage the lottery, of which board John Kelley was made president and treasurer.

This arranged to their satisfaction, the trustees bethought them to the glebe lands as a source of 
capital, and before they left the Stone Tavern instructed Thomas Jefferson and Thomas Mann Randolph (afterwards Governor of Virginia) and Peter Carr to draft a petition to the next General Assembly asking an appropriation of the money arising from the sale of these lands for the benefit of the institution.

Other steps were taken. A committee on plan and location was appointed, and eventually reported. The plan and estimate it brought to the board have not been preserved. Mr. Jefferson was present at the meeting and it is quite probable he condemned the plan as too small for the institution he had in mind, and the paper thereafter was regarded as of little value. He never contemplated the establishment of a mere academy or college as the fruition of all his thinking and planning for a great educational institution in Virginia as a part of the Commonwealth. But he was keeping his own counsel as to the full extent of his plan. The board's ignorance is evident from the report of its committee on site favoring a location beyond the village if the site and building would not cost more than the same advantages in the heart of Charlottesville. The "situation in town already improved" was doubtless the Stone Tavern, where they were in session. It had been bought by Captain Estes but he had never been able to make the payments, and some years later this property and all other standing in his name were sold under deeds of trust. The Captain probably had a great deal to do with the revival of the long dormant scheme for an academy, having a two-fold interest in it-the advantages of such a school in the community of which he was an important member and the profitable sale of 
property which had not proved as good an investment as he had expected.

Six days after this meeting he wrote to Dr. Cooper: "In my letter of January I6th [two months before he became a trustee of Albemarle Academy] I mentioned to you that it had long been in contemplation to get an university established in this State in which all the branches of science useful to us and at this day should be taught in their highest degree. We are about to make an effort for the introduction of this institution." The effort about to be made was in preparation by the trustees of Albemarle Academy without their knowledge.

There were a number of things to be tried before Jefferson was prepared to avow to his colleagues the fact that there was not to be an academy-viz: the result of the petition for a share of the proceeds of the sale of the two glebes of St. Ann and Fredericksville, the outcome of the lottery, and the success of the subscription even then contemplated. So the Sage of Monticello sat in council with the Carrs, Nicholases, Garlands, and others of his neighbors, deftly steering for a haven not down in the chart of the trustees.

Mr. Jefferson was requested by his colleagues to report regulations for the government of the proposed academy, and did so in a letter dated at Monticello, September 7, I8I4, which he addressed to Peter Carr, president of the board. Its sentiments are the convictions he expressed in the preamble to his bill for the better diffusion of knowledge drafted nearly forty years before, when the country was in the midst of the agitation at the beginning of the Revolution. "It is highly interesting to our country," Mr. Jefferson writes, "and it is the duty of 
its functionaries, to provide that every citizen in it should receive an education proportioned to the condition and pursuits of his life." This is the keynote of his philosophy as applied to the educational problem of his time, and it is the basic principle upon which he constructed this first complete outline of what, in his view, the State system leading to and ending in the State university should be. This letter to Peter Carr remains the most striking contribution of an upbuilding kind toward the solution of the problem of general and higher education as that problem was presented a hundred years ago. So wisely were the premises taken and so finely reasoned were the conclusions that both are universally accepted as "the law of the case." It is the prefiguration of the University of Virginia, and in the ampler form it received in the report of the Rockfish Commission, is the source of much that is vital in the modified constitutions of other institutions.

When the master of Carrsbrook received this document he realized that the movement was not to end with an academy. If the original board, of which Mr. Carr was not a member, had wanted to do more than acquire Triplett T. Estes's house and inaugurate a village grammar school, Mr. Carr knew now that the wrong step was taken when Mr. Jefferson was invited to sit with them and confer the advantage of his advice. If it was Mr. Jefferson's plan to have a university there could be no need to convene the trustees of Albemarle Academy in November, according to adjournment, and so the board probably never sat again.

No time was lost in preparing and forwarding to the legislature the petition of the trustees of the academy for the county's share of the income from 
the sale of the glebe lands, a part of the dividend of the Literary Fund and certain amendments to the charter. It must have been early autumn when Peter Carr dispatched the papers to Mr. Watson of Louisa, a member of the lower house; but as late as the following January Mr. Jefferson had "seen no trace of their having been offered." He then wrote to Senator Joseph Carrington Cabell the first of the letters of the correspondence which gives an almost perfect history of their joint labors for the establishment of a great State university.

$\mathrm{Mr}$. Cabell was one of the most useful and distinguished of the descendants of Dr. William Cabell who came from Warminster, England, and settled on the James River, in Goochland County. The family in England, of Norman descent, had been powerful for centuries before the emigre came to the new country and founded a family whose history is interwoven with that of the State and the Nation. "They [the Cabells] not only made the hunting grounds of the savage-a wilderness of wild woods-to feel the yoke of the plow and to blossom as the rose, but, from the time when this section was first represented in the colonial government to the beginning of the Revolutionary period, Cabells were in the House of Burgesses, looking to its interests in the public councils. During the time that tried men's souls, Cabells and their kin were in the conventions guarding the rights of their homeland. And from the war between the mother country and the colonies to the war between the States, the Cabells and their kin were constantly representing this region in the House of Delegates, 
the State Senate, or the House of Representatives of the United States."

Joseph C. Cabell was born in I778, two years after Jefferson's bills for a better diffusion of knowledge were drawn; at the beginning, therefore, of the period of awakening to the need of better educational methods. $\mathrm{He}$ was liberally educated, his schooling beginning at home, as was usual in his social class. From the hands of his tutors he went to Hampden-Sidney but remained only a year, the school not being at its best at the time. Four years of study at the College of William and Mary, especially directed by the venerable President, Bishop Madison, was rewarded with the A. B. degree. For a year or two he divided his time between the study of law, which he never practiced, and an effort to recuperate his health, which grew worse, until in 1802 , by advice of his physician, he sailed for Europe.

His sojourn abroad, planned to last one year, extended to three or four. Mr. Jefferson was an old man when Cabell arrived in America and called to present letters of which he was the bearer. The President was charmed with the character of the young Virginian-so pleased that in time he made him offers of honorable posts at home and abroad, all of which were declined. President Madison, probably, and President Monroe certainly, invited him to places in their cabinets.

A reason for Mr. Jefferson's prepossession was not far to seek. The young Virginian, like the old one, was deeply interested in educational problems -nearly four years had been devoted to investiga-

${ }^{1}$ The Cabells and Their Kin, p. iv. 
tions at Montpelier, Milan, Padua, Rome, Naples, and in France, England, and Holland.

Mr. Jefferson kept Cabell in mind, and when that gentleman, who had been induced by a foreign scholar, De la Coste, to aid him in his plans to establish a museum of natural history at William and Mary, wrote to many of his influential friends on the subject, he received from Mr. Jefferson's private secretary a letter whose style and sentiments were Jeffersonian. "If," said the secretary-or Mr. Jefferson, "I could bring myself to consider Williamsburg as the permanent seat of science, as the spot where the youth of our State for centuries to come could go to be instructed in whatever might form them for usefulness, my objection would, in a great measure, cease. $\times$ But the old College is declining and perhaps the sooner it falls entirely the better, if it might be the means of pointing out to our legislative body the necessity of founding an institution on an extended and liberal scale. $x$ This is the point at which we ought to begin, and this is what you ought to attempt, if you are desirous of doing something which will be of permanent value. This would, indeed, be an object worthy of your attention, and if the amelioriation of education and the diffusion of knowledge be the favorite objects of your life, avail yourself of the favorable disposition of your countrymen, and consent to go into our legislative body. Instead of wasting your time in attempting to patch up a decaying institution, direct your efforts to a higher and more valuable object. Found a new one which will be worthy of the first State in the Union. This may, this certainly will one day be done, and why not now? You may not 
succeed in one session, or in two, but you will succeed at last."

This was the call of the old philosopher, who recognized his need of a leader in the legislature, and Cabell responded. The following year (I808) he became a member of the House of Delegates. In I8ro he entered the Senate and remained until 1829. He had served more than six years in the legislature when Mr. Jefferson wrote him in January, I8I 5,-four of these years in the upper house.

Far from being discouraged by the unexplained neglect of the person to whom Peter Carr had committed the petition, Mr. Jefferson sent copies of that and other important papers to Mr. Cabell. "We always counted on you as the main pillar of their support, and we shall probably return to the charge at the next session," he wrote the Senator, and proceeded to give evidence of his unabated enthusiasm. If the legislature had granted the petition, the results of the proposed lottery, the proceeds of the two glebes, and the dividend of the Literary Fund, supplemented by "a loan for four or five years only of seven or eight thousand dollars," would, he thought, have put it in his power to obtain three of the ablest characters in the world to fill the higher professorships - "three such characters as are not in a single university in Europe!" "With these characters," he adds warmly, "I should not be afraid to say that the circle of the sciences composing that second or general grade would be more profoundly taught here than in any institution in the United States, and I might go further."

It was a full month before Cabell's reply was dispatched-an unavoidable delay. He could not inform Mr. Jefferson why the petition had not been 


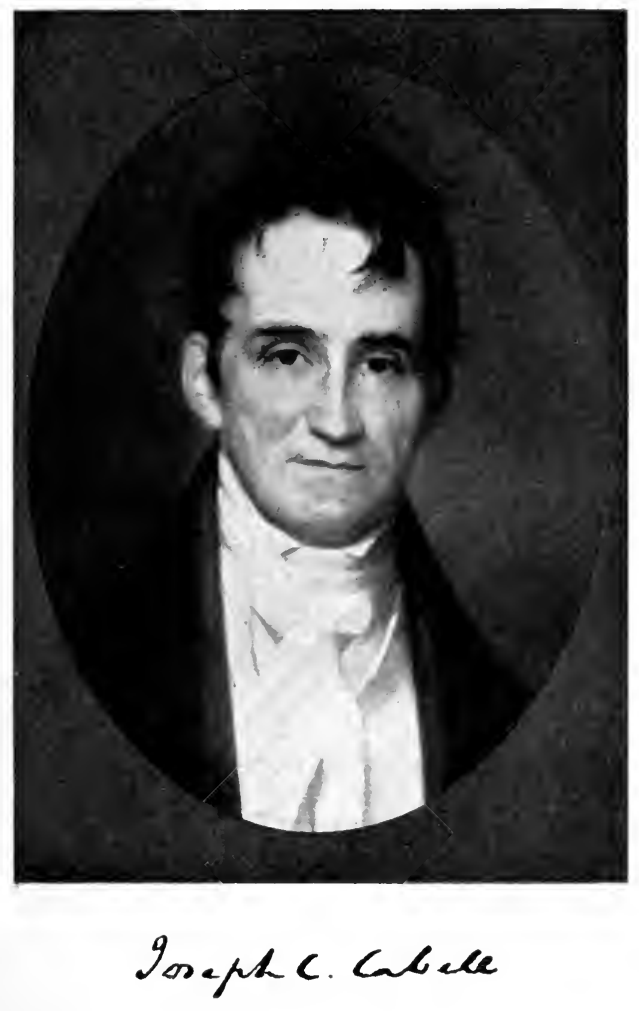


JiBRA
of The

UNIVERSITY

OF

CALIFORNIA 
presented. The papers had never been shown him, and he had heard of them only incidentally, when it had already been decided not to offer them.

The prayer of the trustees of Albemarle Academy was for legal authority to demand and receive certain moneys which had arisen on the sale of the two glebes of the parishes of St. Ann and Fredericksville, with the interest or profits that had accrued; and also annually from the president and directors of the Literary Fund a dividend of the interest or profits of that fund proportioned every year to the ratio which the contributors of the county bore to the rest of the State in the preceding year. The General Assembly was also requested to reduce the number of Visitors, to provide for their appointment and succession, and for such other officers as the trustees might deem necessary; to define their powers and duties, to lay down such fixed principles for the government and administration of the institution as might give it stability; to change its name to that of the Central College, and to make such amendments to the act for the establishment of public schools passed the 22d day of December, I796, as would facilitate its commencement and lighten its execution in the county of Albemarle.

Such was the tenor of the petition which had reached Mr. Watson, and which for some reason he withheld from the legislature. ${ }^{2}$

The Committee of Propositions and Grievances

2 "I was accidentally a witness to a small part of a conversation between Dr. Carr and Mr. Wirt upon the subject of these papers, when Dr. Carr remarked that they had been sent by Mr. Peter Carr to Mr. David Watson of Louisa, who had determined, from some cause or other, that they should not be presented at the last session."-Cabell to Jefferson, March 5, 1815. 
of the House, to whom the petition was referred, allowed every prayer except the one "that all moneys now appropriated to the Literary Fund within the said county may hereafter be vested in the said trustees for the use of the said academy."3

A bill was accordingly drawn and offered. Its vicissitudes were reported by Senator Cabell, who found several objections were urged, among them the fact that the enactment would confer upon the proctor of the college the power and authorities of a justice of the peace within the precincts of the institution.

Jefferson defended the assailed provisions. "The establishment of a proctor," he wrote, "is taken from the practice of Europe, where an equivalent officer is made a part, and is a very essential one of every such institution; and as the nature of his function requires that he should always be a man of discretion, understanding and integrity, above the common level, it was thought that he would never be less worthy of being trusted with the powers of a justice, within the limits of his institution here, than the neighboring justices generally are. and the vesting him with the conservation of the peace within that limit was intended, while it should equally secure its object, to shield the young and unguarded student from the disgrace of the common prison, except where the case was an aggravated one. A confinement to his own room was meant as an act of kindness to him, his parents and friends. In fine, it was to give them a complete police of their own, tempered by the paternal attentions of their tutors. And certainly, in no

${ }^{8}$ Journal, 1815-16, pp. 23, 38 . 
country is such a provision more called for than in this, as has been proved from times of old, from the regular annual riots and battles between the students of William and Mary with the town boys before the Revolution, quorum pars fui, and the many and more serious affrays of later times."

However, the points had to be yielded, after which the bill was passed February 14, 1816. 


\section{CHAPTER III}

THE CENTRAL COLLEGE BECOMES THE UNIVERSITY OF VIRGINIA

Local Antagonisms-Staunton and Lexington-LegrstaTIVE Discussion OF EDUCATIONAL NEEDS-FIRST VisITORS-SITE OF THE COLLEGE-ARCHITECTURAL PLANCORNER-STONE LAID-RECTOR'S FIRST REPORT AND ITS BoLD BID.

The Literary Fund was increased to a large sum by the proceeds of the debt due from the General Government for money advanced by Virginia for the national defense in the war of r8r2. The State now had the means of doing something really significant for popular education, and the president and directors of the fund were required to report a plan for a university to the General Assembly at its session of I8I6-I7.

Behind the movement for a university was the sentiment aroused and enlightened by Jefferson's efforts for popular education, which had been sustained for more than forty years, but Cabell saw other and adverse influences at work, and warned his friend: "You will see the Lexington and Staunton interests striving to draw it [the university] away from Albemarle, and the whole western delegation threaten to divide the State unless this institution should be placed beyond the [Blue] Ridge. Staunton wants the seat of government, and considers the day near at hand when she will be the metropolis of the State. Any brilliant establishment at the eastern foot of the Ridge will shake 
these claims and disturb speculations founded upon them." Two years later he gave Mr. Jefferson more exactly the reasons for this course: "The friends of Staunton and Lexington wish to keep down the Central College. I believe they would oppose the appropriation of a single dollar to it. Should it get even a little annuity it would be established; and one year more would throw Staunton out of the chase altogether, and Lexington in the background. For these reasons I believe the back country will oppose a small appropriation to the Central College with nearly as much zeal as it would the establishment of the university at that place." Mr. Jefferson understood quite well that if the Central College was beaten by the local interests referted to, the University would go elsewhere-a result not at all acceptable to the old statesman and his friends.

Other troubles speedily appeared. Upon the chartering of the Central College followed a quite unusual discussion of educational interests, and the introduction of a bill for a general system, embracing a university. It passed the House during the session of $18 \mathrm{I} 6-17$, but failed in the Senate. Proposals were brought forward also for primary schools which, for a time, were more in favor than any other plan for higher education. Jefferson and Cabell gave their adherence to all of these measures. Both wished to see some system actually begun, however defective the plan. "A system of general instruction," wrote the elder statesman, "which shall reach every description of our citizens from the richest to the poorest, as it was the earliest, so will it be the latest of all the public concerns in 
which I shall permit myself to take an interest. Nor am I tenacious of the form in which it shall be introduced. Be that what it may, our descendants will be as wise as we are, and will know how to amend and amend it, until it shall suit their circumstances. Give it to us then in any shape, and receive for the inestimable boon the thanks of the young and the blessings of the old, who are past all other services but prayers for the prosperity of their country, and blessings for those who promote it."1

The situation was very gloomy at the beginning of the year I8I8. Mr. Cabell's letters lost much of their hopefulness. "It grieves me to tell you that I think our prospects are by no means flattering in the General Assembly. I shall not relax my small exertions in this noble cause. I hunt assiduously around me for every suggestion toward lessening the difficulties on the branch of the primary schools. The hostile interests ${ }^{2}$ alluded to in my last have been constantly at work, and I believe they have produced some effect on the House of Delegates."

The character of the men in the House gave Mr. Cabell much concern. "My belief," he wrote in this same letter, "is, that with such a.House of Delegates nothing can be done. I begin to cast my eye over the State in pursuit of suitable persons to come into the next. If I had the co-operation of some four or five men such as I could describe, everything could be effected. But I do not entirely despair." $\mathrm{He}$

\footnotetext{
${ }^{1}$ Jefferson to Cabell, January I4, I8I8.

${ }^{2}$ Among them the Cincinnati Society, which had already given a large sum to Washington College. "The local friends of Washington College coöperated, of course, and were as much excited as if we had attempted to pull down their college."-Cabell.
} 
returns to the subject in his next letter: "Should we fail here this winter I beg leave to suggest the plan of your endeavoring to get men of talents and influence, in the middle country, to come into the next Assembly. I have already prevailed on Mr. William Brent, of Stafford, to become a candidate. Mr. John T. Brooke will probably join him. I applied to General Cocke a few days ago; he is very averse, but promised to think of it. William G. Poindexter, of Goochland, would come in, but his health will not admit of it. You and Mr. Madison and Mr. Monroe might greatly aid in this business. * * * The northwestern part of Virginia begins to detach itself from the southwestern. A leading man from that section would carry off a wing of the enemy's army. If such a man as General Jackson [of Harrison county, now West Virginia] would come here from that quarter, William Budwell from the south, etc, etc., and would support your views, the game would be safe. This is a delicate subject. But perhaps the happiness of the present and future generations depends upon the execution of the plan."

Concerning the probability of the passage of a really serviceable education bill $\mathrm{Mr}$. Jefferson took a philosophical view. $\mathrm{He}$ wrote $\mathrm{Mr}$. Cabell: "I suppose it probable that the next legislature, after so much debating on the subject, will come with their minds made up for something, and that a provision of some sort will be made, which I think ought to be whatever those who are to live under it think will be best. I believe I have erred in meddling with it at all, and that it has done more harm than good. A strong interest felt in the subject, and through my whole life, ought to excuse me with 
those who differ with me in opinion, and should protect me against unfriendiy feelings. Nobody more strongly than myself advocates the right of every generation to legislate for itself, and the advantages which each succeeding generation has over the preceding one, from the constant progress of science and the arts. We must turn to the affairs of the college, under our particular charge, and consider what we can do for it, on its own scanty funds.",

The act establishing the Central College was passed February I4, I8I6. In October of that year Governor Nicholas ${ }^{4}$ appointed the first Board of Visitors. The members were Thomas Jefferson, James Madison, James Monroe, Joseph C. Cabell, John H. Cocke, and David Watson. Geographically the board was not representative of the State. Jefferson lived within two miles of Charlottesville, Monroe within three, Cocke twenty, Cabell and Madison twenty, and Watson twenty-five. It is quite likely the personnel, the highest the State could afford, was peculiarly satisfactory to Mr. Jefferson, ${ }^{5}$

\footnotetext{
${ }^{3}$ Jefferson to Cabell, February I6, I818.

${ }^{4} \mathrm{He}$ lived at Warren, in Albemarle County, ten miles distant from Monticello.

${ }^{5}$ Virginia Calendar of State Papers, X, 437. Under date of March 25, I8I6, Frank Carr, Secretary of the Board of Visitors of the Albemarle Academy, communicated to Governor Nicholas the fact that "a number of gentlemen who were trustees for a similar purpose [Albemarle Academy] under a former law" had "held a meeting" and recommended Madison, Monroe, Jefferson, Watson, Cocke, and Cabell as "the visitation of the college." He continues: "That the two first named gentlemen will serve is presumed as they were inserted in the list at the instance of Mr. Jefferson. Mr. Watson informed me at our last court that he would, if appointed, and, although I know not that any communication on the subject has been had with the other two, I have very little doubt but
} 
and it is probable this far-seeing man expected what came to pass-a bitter contest over the location of the central institution in the system of popular education in Virginia.

The delay of seven months in the selection of these officers is nowhere explained. The country gentleman of that period gave little attention to public matters in summer. Jefferson and Cabell exchanged letters, but they concerned Say's political economy, the relative merits of holly, cedar, thorn, cockspur, and some other woods and shrubs for hedges, and a variety of sociological topics. As usual Mr. Jefferson knew all there was to know about the matters considered. "The information you give me on the subject of hedges," Mr. Cabell confessed, "is very acceptable; it will exempt me from the mortification of failures in experiments that extend through so large a portion of human life." The Central College was out of mind, apparently, for the time.

The first meeting of the Visitors was called for the 8th of April, r8I7. Jefferson, Cabell and Cocke, just half the members, were present, but the lack of a quorum did not prevent the provisional dispatch of a great deal of important business. The several sites available for the College within a convenient distance around Charlottesville were visited,

they will serve. The gentlemen who have undertaken to act in this recommendation are aware that they do not act in any official capacity, and they can expect that no more weight ought to be given to it than what may be derived from a warm interest in the general concerns of education and their particular anxiety for the success of the Central College. In this view they are confident you will not fail to appreciate their motives and properly to excuse what, under other circumstances, might seem an improper interference in matters pertaining exclusively to your office." 
and the one offered by John Perry, "a mile above the town," was purchased. ${ }^{6}$

The first legal meeting of the Visitors was on May 5, I8I7- "present" (quoting the minutes in Mr. Jefferson's hand) "James Monroe, James Madison, John H. Cocke, and Thomas Jefferson." Cabell was prevented from attending by a visit he was under the necessity of making to Williamsburg and the county of Lancaster. Watson's absence is unexplained. To attend the meetings of this board Mr. Madison had to drive from his home, "Montpelier," in Orange County, twenty miles over rough roads, and General Cocke traveled by similar conveyance an almost equal distance, from "Bremo," on the James River in Fluvanna County. Mr. Monroe's home was "Ash Lawn," on the eastern slope of Carter's Mountain, about two miles from Monticello; but he was President of the United States at this time, and probably journeyed from Washington, staying over night at Mr. Madison's.

Valentine W. Southall $1^{7}$ was appointed secretary to the board, his father-in-law, Alexander Garrett, who had appeared at the meeting as bearer of the records of the trustees of the Central College, was elected proctor, and requested to act as treasurer also until that officer could be appointed.

From this moment business was dispatched without delay. The selection and purchase of Perry's lands as the site of the Central College were approved and ratified with stately formality, and straightway the proctor was instructed to inquire

'John Perry retained a part of his tract of land and built on it, and for years occupied, the residence known as "Montebello."

${ }^{7}$ Grandson of Lucy (Henry) Wood, sister of Patrick Henry. 
into the state of the rights and claims that had been transferred by the Albemarle Academy and to demand and receive so much of the money arising from the lottery, the subscriptions or the sale of the glebes as might be needed to pay for the lands purchased from Perry. Throughout the letters received by the proctor from Mr. Jefferson during the building of the College and, later, the University, runs his insistence that payment be prompt.

The amount needed to pay Perry was $\$ 1,5 \mathrm{I} 8.75$, this being the total cost of the two hundred acres, "on which," as Mr. Jefferson wrote in his first report to the Speaker of the House of Delegates, "was an eligible site for the College, high, dry, open, furnished with good water, and nothing in its vicinity which could threaten the health of the students."

Mr. Jefferson presented a plan, which had been prepared and submitted to the trustees of Albemarle Academy, for erecting a distinct pavilion or building for each professorship, and for arranging these around a square, each pavilion to contain a school-room and two apartments for the accommodation of the professor. The board decided that one of these buildings should be erected at once, and the proctor was requested, "as soon as the funds are at his command," to "agree with the proper workmen for the building of one, of stone or brick below ground, and of brick above, of substantial work, of regular achitecture, well executed, and to be completed if possible during the ensuing summer and winter." Provision was made for ten dormitories for students on each side, "of brick and of regular architecture."

These things and more the Visitors did at this 
meeting, and their doing was really the first effective acts in the building of the Central College. The board's decrees were carried into effect with a good will, and so promptly that at the next meeting, which occurred July 28, I8I7, the Visitors decided to invite Dr. Knox of Baltimore to the chair of "languages, belles lettres, rhetoric, history and geography!" And failing to get Dr. Knox, who had "withdrawn from business," "Doct. Thomas Cooper of Pennsylvania" was invited to the chair of chemistry at their meeting on October 7 .

On the 6th of October, 1817 , the first stone in the building of the College was laid with due and solemn ceremony by the Charlottesville Lodge of Masons. Jefferson, Madison, and Monroe were present, and "a large company of citizens attended."s Mr. Cabell, General Cocke, and Mr. Watson were probably there too, for they attended at Charlottesville that day a meeting of the Agricultural Society ${ }^{9}$ of Albemarle and the next a session of the Board of Visitors of the College.

In December, Cabell was again in attendance on the meetings of the Senate, while Jefferson, no doubt, was engaged in the preparation of the report of the Visitors to the Speaker which bears the date of January 6, I8I8. It is even probable that the main feature of this document, now to be quoted, was agreed upon at the October meeting, when the Visitors, contrary to their early practice, sat two or three days, instead of one, and that Mr. Jefferson, as he witnessed the laying of the corner-stone of the Central College on the 6th of October, had in his

${ }^{8}$ Richmond Enquirer, Oct. I0, I8I7.

- Madison was its president. 
pocket a rough draft of the plan, which was eventually completed in the following bold way:

"We are happy to see that among the cares for the general good which their station and the confidence of their fellow-citizens have made incumbent on them this great political and moral want [education] has not been overlooked. By a bill of the last session, passed by one branch, and printed by the other for public consideration, a disposition appears to go into a system of general education, of which a single university for the use of the whole State is to be a component part. A purpose so auspicious to the future destinies of our country, which would bring such a mass of mind into activity for its welfare, cannot be contemplated without kindling the warmest affections for the land of our birth, with an animating prospect into its future history. Well-directed education improves the morals, enlarges the minds, enlightens the counsels, instructs the industry, and advances the power, the prosperity and the happiness of a nation. But it is not for us to suggest the high considerations, which their peculiar situation will naturally present to the minds of our lawgivers, encouraging a pursuit of such incalculable effect; nor would it be within the limits of our dutiful respect to them, to add reasonings or inducements to their better understanding of what will be wise and profitable for our country. But observing that in the bill presented for public consideration a combination of public and private contributions has been contemplated; and considering such an incorporation as completely fulfilling the view of our institution, we undertake to declare, that if the legislature shall think proper to proceed to the establishment of an university, and to adopt for its location 
the site of the Central College, we are so certain of the approbation of those for whom we act, that we may give safe assurance of the ready transfer to the State of all the property and rights of the Central College, in possession or in action, towards the establishment of such an university, and under such laws and provisions as the legislature shall be pleased to establish; and that we ourselves shall be ready to deliver over our charge to such successors, or such other organization, as the legislature shall be pleased to ordain, and with increased confidence of its success under their care."

By this transfer, according to the report, the State would gain a great deal: "The subscription papers already returned amount to $\$ 35$, IO2, to which are to be added $\$ 3,195.86$, the proceeds of the sales of glebes in the county of Albemarle. $* * *$ To these sums, making together $\$ 38,297.86$, particular papers of which we have information, although not returned, will add about $\$ 8,000$, enabling us to count with safety on forty-six or forty-seven thousand dollars. Other papers are still out, of which we have no information, but which we trust will make further sensible additions to our stock."

It was shrewdly intimated that what had been planned and done in the way of college buildings was in the direction of a large institution or capable of being given that direction, "until the institution shall become worthy the station of our State in the scale of its confederates and of the nations of the world."

The disposal of the buildings is explained. "Instead of constructing a single and large edifice, which might have exhausted their funds, and left nothing, or too little, for other essential expenses, 
they thought it better to erect a small and separate building, or pavilion, for each professor they should be able to employ, with an apartment for his lectures, and others for his own accommodation, connecting these pavilions by a range of dormitories, capable each of lodging two students only, a provision equally friendly to study as to morals and order.

"This plan offered the further advantages of greater security against fire and infection, of extending the buildings in equal pace with the funds, and of adding to them indefinitely hereafter, with the indefinite progress of contributions, private or public; and it gave to the whole, in form and effect, the character of an academic village."

Here we have the first bodying forth of "the academic village," never before contemplated, which soon took material shape and has since developed into the most unique and beautiful group of academic edifices in the world.

This paper the Speaker was requested to communicate to the House in such form as he thought best. Mr. Jefferson anxiously awaited news of the impression the report had made in Richmond-"because that shows how near we are to the accomplishment of a good college, one that cannot but be thought of some value to the State-and the urgency of their enabling us to complete it." 10

Cabell's report was scarcely satisfactory: "I have been particular in my inquiries as to the impression made by it on the members of the House of Delegates. It seems to have been received as an able production with some great names attached to it; but does not appear to have had any material in-

${ }^{10}$ Jefferson to Cabell, January I5, I818. 
fluence on the feelings or opinions of the majority of the House. Among an enlightened few it has been read with favor and admiration. It cannot but add weight to our claims on the legislature." ${ }^{11}$

In the same letter Cabell said the popular scheme was to give all the Literary Fund to primary schools, and on the next day he wrote: "As I came out of the capitol to-day I received from one of the doorkeepers the enclosed copy of the bill reported by the Committee on Schools, which I have hastily looked over and in regard to which I confess myself greatly disappointed. Indeed, sir, the prospect before us is dreary."

And yet, in less than a month, he had the pleasure of dispatching to his venerable friend at Monticello this very good news :

"I hasten to apprise you that our proceedings now seem likely to eventuate differently from what I have heretofore expected. The school bill came up to the Senate in the form of Mr. Hill's amendment. We engrafted upon it a provision for an University. In that shape it passed here by a majority of fourteen to three. This important vote took place yesterday. The bill has gone back to the House of Delegates. An attempt has been made to postpone it, and lost by an immense majority. The bill, with the amendments of the Senate, is ordered to be printed. It is contemplated to amend it, so as to provide that the appropriation for the University shall not interfere with any further appropriation that may be necessary for the education of the poor. The bill now gives $\$ 45,000$ per annum to the poor, and $\$ 15,000$ to the University. It is believed that $\$ 15,000$ more

${ }^{11}$ Cabell to Jefferson, January 22, I8I8. 
will be necessary for the poor; and $\$ 60,000$ is all the product of the fund at this time. But the product will soon be swelled to $\$ 90,000$, so that it will not materially affect the appropriation for the University. In this shape it is believed the bill will pass. It is provided in the bill that the Governor and Council shall choose one commissioner from each Senatorial district in the State, as laid off by the act of the last Assembly; that these commissioners shall meet at Rockfish Gap on the first of August, and adjourn from place to place, and time to time; that they shall report to the next Assembly the best site, plan, etc., and the next Assembly will have the whole subject in their power. We have fifteen districts on this side the Ridge, and I think we are safe in the hands of the Executive. If this bill passes, perhaps, our policy will be to invest all our funds in buildings, and get them as far advanced by August as possible. But I will not speculate on uncertainties. I tremble with anxiety for the great result I anticipate." 12

The bill passed February 2I, I8I8. It was an elaborate program for a notable gathering and a sharp contest for the site of the future University of Virginia. To Mr. Jefferson and his co-worker for Charlottesville it involved, in addition to the loss of location, the virtual minifying, if not eventual destruction, of the Central College. And so it came to pass in that summer long ago there was much shrewd preparation for the meeting at the tavern at Rockfish, on the summit of the Blue Ridge, where there was to be another opportunity for the display of Mr. Jefferson's leadership.

The essential provisions of the sections engrafted

${ }^{12}$ Cabell to Jefferson, February 20, I8I8. 
on the bill for the establishment of schools for poor children were: The establishment of a university to be called "The University of Virginia" in some convenient and proper part of the State; the appointment by the Executive of a body of twenty-four discreet persons as a Board of Commissioners for the University, one member from each of the twentyfour senatorial districts, whose duty it was to inquire and report to the legislature, "first, a proper site for the University; secondly, a plan for the building thereof; thirdly, the branches of learning which should be taught therein; fourthly, the number and description of professors; and fifthly, such general provisions as might properly be enacted by the legislature for the better organizing and governing the University ;" the meeting of the Board of Commissioners for the University on the first day of August (r818) at the tavern in Rockfish Gap on the Blue Ridge for the purpose of selecting a site and the discharge of the other duties imposed by the bill; the appropriation of $\$ 15,000$ out of the Literary Fund, available as soon as the site of the institution was ascertained by law, for the purchase of lands, erection of buildings, endowment, etc.; a requirement that the commissioners receive any voluntary contribution, whether conditional or absolute, whether in land, money or other property offered through them to the president and directors of the Literary Fund, for the benefit of the University, and to report the same to the legislature; the appointment by the president and directors of the Literary Fund of a board of thirteen visitors, empowered to select their own rector, these to constitute a body corporate under the name and style of "The Rector and Visitors of the University of Virginia." 


\section{CHAPTER IV}

\section{THE ROCKFISH COMMISSION}

Cabeli Fears the Influence of Staunton and Lexington -MEMBERS OF THE COMMISSION-JEFFERSON'S LEADERSHIP-THE COMMISSIONERS' REPORT-STRUGGLE RENEWED IN THE LEGISLATURE-CABELI'S FINE MANAGEMENT.

Mr. Cabell believed that if the Commission should decide upon Charlottesville as the location for the University of Virginia, the defeated aspirants, Staunton and Lexington, would renew the contest in the House of Delegates; and in that event he had grave doubts as to the issue. In the Senate he felt safe, but in the House the membership impressed him unfavorably.

Washington Academy at Lexington was a dangerous rival. Its plant was already worth $\$ 25,000$, and a wealthy old gentleman, a Mr. Robinson, of Rockbridge County, whose estate was valued at $\$ 100,000$, had indicated a willingness to give his property at his death to the University provided it was located at Lexington. Private subscription was expected to yield $\$ 25,000$, so the cash bid was $\$ 150$,$\infty 00$ as against the sum, about one-third as large, offered by the Central College, and "a certain class of members" was disposed to put the institution up to the highest bidder. The clause in the law establishing the University which required the committee not only to accept gifts but to report them to the legislature, paved the way to bidding, and opened an avenue for an appeal from the decision of the 
commissioners to the legislature by providing for a final consideration of the bids or "gifts" in the General Assembly.

In this situation Cabell was disposed to prepare for the struggle in an effective way. He wrote to Mr. Jefferson: "It is very important to have an inter-mixture of true friends and liberal spirits from the middle country. I turned my eyes toward Randolph Harrison. $\mathrm{He}$ is precisely such a man as would have the most effect on such an occasion. He would be a host on our side. I wrote to General Cocke pressing him to come forward, and urging him to endeavor to prevail on Washington Trueheart, of Louisa, and Randolph Harrison to offer for their respective counties. $* * *$ Mr. Harris will offer in Louisa, and he will do very well. Probably no one has as much influence with $\mathrm{Mr}$. Carey and Mr. Harrison as you have. The crisis is great and extraordinary means are necessary to accomplish the great object in view. I take the liberty to suggest to you the idea of your writing immediately to those gentlemen by special messenger. Mr. Eppes could awake his friends to the support of Mr. Harrison. Perhaps you may not approve this suggestion. If you should not, I hope you will ascribe it to an anxiety for the welfare of the Central College, and the cause of science, that arises above that which I feel for my domestic concerns."

Mr. Cabell was very uneasy, too, about the membership of the Commission. "I am discussing the question among our friends here," he wrote February $2 \mathrm{I}, \mathrm{I} 8 \mathrm{I} 8$, "whether it would be proper to name you as a commissioner. The duties of the board will be various and important. It is of great consequence that I should be forthwith informed whether 
you would serve if elected. In your answer, if possible, leave me a discretionary power. I see no objection to Mr. Madison's serving-and should he be appointed, I entreat that you will lay before him the high considerations that should induce him to accept the appointment. Be pleased to do this without delay. All I want in this business is fair playto put this subject on a footing of just reciprocity between the two sides of the mountain."

Mr. Jefferson's reply shows the unselfish nature of his connection with this important matter:

"I congratulate you, sincerely, on having something begun on the subject of education. Whatever be its faults, they will lead to correction. You seem to doubt whether Mr. Madison would serve if named a commissioner for the location, etc., of the University? but there can be no doubt that he would, and it is most important that he should. As to myself I should be ready to do anything in my power for the institution; but that is not the exact question. Would it promote the success of the institution most for me to be in or out of it? Out of it, I believe. It is still to depend ultimately on the will of the legislature; and that has its uncertainties. There are fanatics both in religion and politics, who, without knowing me personally, have long been taught to consider me a raw head and bloody bones, and as we can afford to lose no votes in that body, I do think it would be better that you should be named for our district. Do not consider this as mock-modesty; it is the cool and deliberate act of my judgment. I believe the institution would be more popular without me than with me; and this is the most important consideration-and I am confi- 
dent you would be a more efficient member of that body than I should. Do then, dear sir, act on this subject without any scruples as to me or yourself. Regard nothing but the good of the cause."

Mr. Cabell declined to serve as the commissioner from his district, which was Mr. Jefferson's also, and left to four or five of the ex-President's friends the question whether his reasons for not going on the board should be held as conclusive. When the Governor announced the commissioners Jefferson and Madison were found to be of the number-a fortunate circumstance. The other members were Creed Taylor, Peter Randolph, James Breckinridge, Archibald Rutherford, Archibald Stuart, William Brockenbrough, Henry E. Watkins, A. T. Mason, Hugh Holmes, Phil C. Pendleton, Spencer Roane, John M. C. Taylor, J. G. Jackson, Phil Slaughter, William H. Cabell, Nathaniel H. Claiborne, William A. C. Dade, William Jones, Thomas Wilson, Nicholas Faulcon, Peter Johnson, and Littleton W. Tazewell.

There were no better men in Virginia, and the State quite safely committed to their hands its interest in this matter of paramount importance.

The commissioners met at the tavern in Rockfish Gap, in the Blue Ridge Mountains, on Saturday, August I, I8I8, twenty-one of the twenty-four members present. Mr. Jefferson was unanimously elected chairman, and Thomas W. Maury, secretary. The first business taken up was the selection of a site for the University. Mr. Jefferson, it is said, submitted a long list of octogenarians then living in Albemarle as proof of the healthfulness of

${ }^{1}$ Jefferson to Cabell, February 26, I8I8. 
that section, and exhibited a model of the State, made of cardboard, which ingeniously demonstrated that Charlottesville was more really the geographical centre of the State than either Staunton or Lexington, and that it was nearer than either of these towns to the centre of white population. Much of the first day's session was taken up with the discussion, and decision was finally deferred on the motion of Mr. Rutherford.

The question of visiting the various sites offered for the University was disposed of by the motion of Judge Dale to adjourn to Lexington-a proposition made, as he said, to test the sense of the board. The motion was unanimously negatived; the commissioners also refused to adjourn to Staunton.

At the meeting on Monday, the $3 \mathrm{~d}$ of August, Judge Roane called up the matter of deciding upon the site, and the vote being taken, Breckinridge, Pendleton and J. M. C. Taylor voted for Lexington, Stuart and Wilson for Staunton, and Taylor, Randolph, Brockenbrough, Rutherford, Watkins, Madison, Mason, Holmes, Roane, Jackson, Slaughter, Cabell, Claiborne, Jefferson, Dade and Jones for the Central College. The significance of Joseph C. Cabell's remark to Jefferson, "We have fifteen districts on this side of the Ridge" (as against nine on the other) was prophetic. The fifteen voted for Mr. Jefferson's site.

A select committee consisting of Jefferson, Madison, Roane, Stuart, Dade and .Breckinridge had been appointed by ballot on Saturday to consider and report on all matters before the Commission except the site for the University. This report was now submitted, amended, and unanimously adopted.

The document as passed by the committee was in 
Mr. Jefferson's hand. The copies presented to the Speakers of the two Houses were made by several hands, dividing the work in order to expedite the departure of the commissioners, and were, as $\mathrm{Mr}$. Jefferson thought, very imperfectly legible. As it was important that it should be printed correctly, he sent the original draft along with the copies for the use of the printers. ${ }^{2}$

Mr. Cabell was in Richmond when the legislature convened, going about the business of the University persuasively and tactfully. He conferred with Samuel Carr and William F. Gordon, members of the House of Delegates from Albemarle, and they agreed to get Samuel F. Taylor of Chesterfield to bring forward the subject of the University in the House, because his location in the State gave him less appearance of local interest and prejudice. Of course, he keeps Mr. Jefferson informed; tells him that the clouds seem to be scattering. True, some votes about William and Mary will be lost, but nothing like a serious diversion in favor of a western site is to be apprehended. Indeed, Philip R. Thompson of Kanawha, and the delegates from that western quarter, had decided to support Charlottesville. A portion of the Assembly was, it was known, opposed to the whole question, and it was impossible to say to what extent these could unite with the Lexington interests to jeopardize the measure. But the prospect was cheerful. Even the Speaker was frankly favorable to Mr. Cabell's interests.

But when a week later Speaker Banks of Madison County had appointed the select committee to con-

${ }^{2}$ Jefferson to Cabell, November 20, I8I8. 
sider the commissioners' report, the result was not pleasing to Mr. Cabell. "There is a decided majority in favor of the Central College; but the eastern members are less attentive than the western. I have urged the importance of having a full meeting before the final question is taken. Mr. Taylor is aware of the danger. The committee has had two meetings; at the first, it was decided to report by bill. Mr. Taylor has copied your bill, and at the second meeting offered it to the committee. The friends of Lexington wish to have the clause of location reported with a blank. I think it will ultimately be decided to fill the blank with the Central College. At the second meeting, this morning, the Valley members called for time to consider the provisions of the bill; the real object was to have time to manœuvre. The motion was resisted but carried; some of the friends of Charlottesville voting with them. The members from Rockbridge called for a calculation to prove the assertion in the report that Charlottesville is nearer to the centre of population than Staunton or Lexington. The object seemed to be to draw out your calculations exhibited to the commissioners. The answer given by an eastern member was, that each member might satisfy himself, by reference to the census of I8Io. The point was lef/ unsettled. It will come on again at the next meeti $g$ on a motion to strike out Charlottesville from the bill. The Valley members will be strongly opposed to the Central College. The members from beyond the Allegheny will divide. Those south of Kanawha will generally vote with us, as $\mathrm{Mr}$. Thompson informs me. The prospect is still favor- 
able; but the effect of intrigue and management is beyond the reach of calculation."'s

At the third meeting of the select committee the enemies of the Central College came within one vote of winning a tactical victory. The motion was to report the bill with a blank as to the site, and it was lost only by the casting vote of the chairman. It was then reported to the House with the Central College as the site of the proposed University of Virginia.

"I am really fearful for the ultimate fate of the bill. Since the date of my last I have discovered that the delegation from the west are forming a combination among themselves to vote against the bill on its passage. Finding themselves in a minority on the question of the site, they will endeavor to defeat the measure altogether for the present. There is a party in the east in favor of putting down the Literary Fund. Should these parties unite on the question of the passage of the bill it will be lost; and this result is much to be apprehended."'4

To add to the adverse circumstances, Mr. Cabell's health was so delicate as to cause great uneasiness among his friends. He was urged to leave Richmond to insure its recovery. "I will not stir from the seat of government," he answered, "till this business is settled. Even if the dangers to my life existed which they apprehend I could not risk it for a better cause."

Mr. Jefferson urged that the matter be brought to a vote in the House, and the bill got up to the Senate before Christmas. But the Senate was without a quorum and the House so nearly so that it was

\footnotetext{
${ }^{3}$ Cabell to Jefferson, December 14, I8I8.

${ }^{4}$ Cabell to Jefferson, December I7, I818.
} 
not prudent to risk a vote at the time. In the meantime the hostile interests were daily gaining force by intrigue and management, while the party altogether opposed to the University, wherever located, was growing so rapidly as to afford grounds for fearing a total failure of the measure. "I this morning counted up twenty-six votes of this description on this side of the Ridge; and there are doubtless many others. Many of the western members will take the same course, particularly if they lose the site. * * * The party hostile to the University come chiefly from the lower country, and are within convenient distance of William and Mary. The better educated part of them, whilst they, their sons, connexions, or friends, have been educated at William and Mary, quote Smith, the Edinburgh $R e-$ view, and Dugald Stewart, to prove that education should be left to individual enterprise."

In spite of his illness, Cabell seemed tireless. All day and most of the night the best energies of his mind and body were freely dedicated to the cause he had so much at heart, and it was due to him that success was achieved.

The bill was discussed elaborately and warmly in the committee of the whole House on the I8th day of January, I8I9, and its fate was decided by a vote on a motion to amend by striking the Central College from the bill. The motion was defeated decisively, only sixty-nine favoring it while one hundred and fourteen voted for the Central College. The victory was so decisive that $\mathrm{Mr}$. Cabell dispatched a jubilant letter to his venerable correspondent at Monticello.

Judge Briscoe G. Baldwin of Augusta, as soon as the vote was announced, made an eloquent and gen- 
erous appeal to the western delegation, of which he was a member, to dismiss local feeling and unite with the friends of the measure in making it a law. It was evidently a subject of regret to Mr. Cabell that he did not hear Judge Baldwin, but this staunch friend of the University was so wrought up by his long struggle and by his fears that he left the House of Delegates to avoid witnessing the decisive vote"to escape the shock of feeling." Judge Baldwin's magnanimity excited general admiration. The bill was advanced to a third reading, and the next day passed the House with only twenty-eight votes against it. On the 2oth Senator Cabell secured its commitment. The committee promptly disposed of several hostile amendments proposed by Mr. Johnson, and adjourned to give him time to prepare others. The Senate disposed of all opposition by passing the bill, January 25, I8I9, as it had come from the House, the vote being ayes sixteen, nays seven.

The bill passed none too soon, for Mr. Cabell's physical condition was grave. He attempted to take part in the debate in the Senate, but at the beginning of his effort a hemorrhage forced him to abstain, and as soon as the bill was a law he retired to the home of his friend Judge Walter, at last seriously alarmed by his condition. 


\section{CHAPTER V}

\section{PERILOUS ANTAGONISM.}

Cabeli Advises Laying Out Ali the Money in BuildingLOANS FROM THE LITERARY FUND-HOSTILE EFFORTS TO Absorb its INCOME-CABeIL's Desire to Retire From THE SENATE-CRY Against Unitarianism-Rotunda BEGUN-REMISSION OF LOANS FROM THE LITERARY FUND -Proposed Removal, of William and MaRY-How DEFEATED.

Mr. Cabell's announcement that "we have got possession of the ground and it will never be taken away from us," has proved true, ${ }^{1}$ but the resourceful coadjutor of Mr. Jefferson was not blind to the fact that there were many difficulties to be encountered before the University would be in successful operation. "The contest is not over," he wrote a few days later, and this prophecy proved true, also. The University authorized by the law of January 25, I8I9, was on a splendid scale, but the legislature had not provided an adequate capital for realizing the plan. To procure the means of giving form to Mr. Jefferson's dream was still the problem. The Visitors could only appeal to the legislature, and there they found many biased and prejudiced by the heated campaign which had ended in their defeat and discomfiture. Jefferson and Cabell set themselves resolutely to the task of making headway against these antagonisms.

The former at first displayed some eagerness to put the instituton into operation, and gave much time to the consideration of professors, while $\mathrm{Mr}$.

\footnotetext{
${ }^{1}$ Cabell to Jefferson, February 9, 1819.
} 
Cabell thought it wiser to pursue another course. He apprehended an attempt the following winter (I8r9-20) to repeal the law establishing the University. "This furnishes me," he wrote on the $22 \mathrm{~d}$ of February, I8I9, "with a strong reason not only to lay out all the money at present in buildings, but convinces me of the importance of rather keeping the houses empty until a sufficient number can be got into a state of readiness to receive some half dozen eminent professors than to fill them successively as they are finished, with perhaps here and there a man obnoxious to public prejudice."2

Aside from the subscriptions there was no income except the $\$ 15,000$ from the Literary Fund, ${ }^{3}$ and that could be paid in full only when the earnings of that fund were at least $\$ 60,000$ a year, because $\$ 45,000$ was set aside as intangible for any purpose but the support of the schools for the poor children provided for by the bill of January, I8I9. Fortunately the fund was prosperous.

At the session of $1819-20$ an application was made to the legislature for $\$ 80,000$, and then for half that sum, but both requests were refused. Later a bill authorizing the Visitors to borrow $\$ 60,000$ was passed with little trouble. The annuity of $\$ \mathrm{I}_{5}, 000$ was pledged for repayment. Forty thousand of this sum was received in April, I820, and twenty thousand in the following January.

2 The person referred to as probably obnoxious was $\mathrm{Dr}$. Cooper, of whom more at another time.

${ }^{3}$ By an act of the Virginia legislature in the year I809 all escheats, confiscations, forfeitures, and all personal property accruing to the Commonwealth as derelict and having no rightful owner, which had accrued after the $2 \mathrm{~d}$ day of February, I8Io, or which should thereafter accrue to the Commonwealth, were appropriated to the encouragement of learning. The fund thus formed was known as the Literary Fund. 
At the close of the year 1820 the University was indebted to the Literary Fund in the sum of $\$ 60,000$. At this time Mr. Jefferson's estimate of the cost of the buildings completed was $\$ 162,364 .{ }^{4}$ Completion meant to him ten pavilions or professors' residences, six "hotels for dieting the students," one hundred and four domitories, and two hundred acres of land. It was now seen that the former estimate of the cost of these betterments was nearly $\$ 25,000$ too low. ${ }^{5}$

Jefferson wrote to Cabell pointing out the needs of the University, which, in his opinion, would be met by a remission of the loan of $\$ 60,000$, a supplementary sum of $\$ 45,000$ to liberate the annuities of I $82 \mathrm{I}-2-3, \$ 8,364$ to make good a deficit estimated by the proctor, $\$ 40,000$ for the building of the library, and an equal partition of the Literary Fund between the elementary schools and the University-say $\$ 30,000$ to each. This furnishes abundant evidence, if any were needed, that in the matter of asking financial support Mr. Jefferson's courage was not abating.

Cabell's reply was: "We shall probably have to fall down in our petition for a sum sufficient to finish the buildings and let the rest lie for another session. We shall have the academies to contend with this year." This was a real danger which arose from an effort to embarrass the University by absorbing the disposable part of the Literary Fund by appropriating a share of its income to William and Mary, Hampden-Sidney, Washington College, New London Academy, and the University. This move-

\footnotetext{
- Memorandum accompanying Jefferson's letter to Cabell, November 28,1820 .

Ibid.
} 
ment was strong tactically, and not the least of its menaces was the probability that it would consolidate the elements antagonistic to the University by an appeal to their cupidity.

But Mr. Cabell was not disconcerted. He boldly announced and advocated the doctrine that no public money should be appropriated to any institution except upon the express condition that such college should, like the University of Virginia, be at all times and in all things subject to the control of the legislature.

It was at this time that Senator Cabell became convinced that he ought to retire from public life in the interest of his health, which had been seriously imperilled by his efforts in behalf of the University, and of his private fortune, which had suffered by his absence from his estate. "I have been here thirteen winters. My object now is domestic, rural, and literary leisure."

The letter in which he announced his purpose reached $\mathrm{Mr}$. Jefferson at one of the darkest periods cited by that event. The faculty paid him a high of the history of the University. It was a severe blow to the recipient, who was now well stricken in years, having almost reached his seventy-eighth birthday. "The gloomiest of all prospects," he replied to Mr. Cabell, "is in the desertion of the best friends of the institution; for desertion I must call it. I know not the necessities which force this on you. General Cocke, you say, will explain them to me; but I cannot conceive them, nor persuade myself they are uncontrollable. I have ever hoped that yourself, General Breckinridge, and Mr. Johnson would stand at your posts in the legislature until everything was effected, and the institution opened. 
If it is so difficult to get along with all the energy and influence of our present colleagues in the legislature, how can we expect to proceed at all, reducing our moving power? I know well your devotion to your country, and your foresight of the awful scenes coming on her, sooner or later. With this foresight, what service can we ever render her equal to this? What object of our lives can we propose so important? What interest of our own which ought not to be postponed to this? Health, time, labor, on what in the single life which nature has given us, can these be better bestowed than in this immortal boon to our country? The exertions and the mortifications are temporary; the benefit eternal. If any member of our college of Visitors could justifiably withdraw from this sacred duty, it would be myself, who, 'quadregenis stipendiis jamdudum peractis,' have neither vigor or body of mind left to keep the field. But I will die in the last ditch. And so I hope you will, my friend, as well as our firm-breasted brothers and colleagues, Mr. Johnson and General Breckinridge. Nature will not give you a second life wherein to atone for the omissions of this. Pray then, dear, and very dear, sir, do not think of deserting us; but view the sacrifices which seem to stand in your way as the lesser duties, and such as ought to be postponed to this, the greatest of all. Continue with us in these holy labors, until having seen their accomplishment, we may say with old Simeon, 'nunc dimitis, Dominie." ",

Mr. Cabell confessed that it was not in his nature to resist such an appeal, and at once announced his candidacy for another term in the Senate. He

'Jefferson to Cabell, January 3I, I82I. 
also made every exertion to get the liberal members of the legislature to return for another session and endeavored to induce others to supplant members of proved inferior capacity.

The expected reverse in the legislature on the subject of another loan of $\$ 60,000$ did not occur, for on February 2I, I82I, a bill authorizing it was passed, increasing the indebtedness of the institution to the Literary Fund to $\$ 120,000$.

The next session of the legislature-I82I-22found the University as usual in need of more money, and its friends forced to renew the old contention with the old enemies. No opportunity was neglected by these antagonists to depress the interests of the University. One was afforded them by Jefferson's relations with Dr. Cooper. The cry of Unitarianism was raised, and the vociferation was renewed when it became known that Mr. Ticknor and Mr. Bowditch of Massachusetts were under consideration for professorships. Their religious views were not known, and the clergy professed uneasiness. Jefferson made no response. "Silence and resignation have sometimes greater effect than opportunity," he wrote to a friend, putting into an aphorism what Tennyson afterward expressed in a couplet :

"The noblest answer unto such

Is perfect stillness when they brawl."

All this and more (such, to name two examples, as the claim of the clergy that they were to be excluded from the University and the report at the Synod of I82I that Mr. Jefferson had said the religious communities might well be afraid of the progress of the Unitarians in the South), Mr. Ca- 
bell met with the tact and sound sense which had often served "the holy cause" with good results. He conferred with Dr. Rice, a liberal minded Presbyterian clergyman, who displayed enlightened friendship for the University, and convinced him that no preference was to be given Unitarians. The colleges that were pressing claims before the legislature he met with a ready reciprocity. $\mathrm{He}$ and $\mathrm{Dr}$. Rice concurred in the propriety of a firm union between the friends of the University and these colleges "as to measures of common interest." Appeasing and conciliating, Mr. Cabell diligently sought to prepare the way for the success of the University's measures. But his amiable energies could not avail, and the legislature adjourned with the record of having resisted his persuasive logic. It was the first Assembly that had done so in five years. But the near future showed that a blunder inad been made, for the institution was popular in the State if not in the legislature. In the spring of I822 it was made a test in certain counties-as Mecklenburg, Lunenburg, Brunswick, Greenesville, Norfolk and Essex-and the members who voted against the University in the previous legislature were turned out or compelled to promise to vote with Cabell.

The session of $1822-3$ found the University under increased need of funds to continue its building operations. Its friends were uncertain, however, as to the best form in which to present their requests to the Assembly. The annuity was burdened with the interest on the \$120,000 borrowed from the Literary Fund. If the legislature could be induced to remit this debt the annuity would be emancipated, which would be $\$ 7,200$ saved annually. The library 
was the next building to be erected, and there was no money to pay for its construction. Many of the wisest friends of the institution thought the best course was to do no more than ask for an appropriation to be applied to this object. But how much? The estimate had soared from about $\$ 44,000$ to $\$ 70,000$. This was dismaying.

Cabell favored asking for $\$ 50,000$ for this purpose and finally that figure was fixed upon, but afterwards advanced to $\$ 60,000$. After long and disheartening delays the measure became a law, and the building of the Rotunda was begun. "I earnestly hope," Cabell wrote, "that this loan will finish the building. We must never come here again for money to erect buildings. It would be good policy to expend $\$ 60,000$ on the library, should it require so much, and not direct any part of it to the payment of existing debts. Should the fund fall short I would rather ask for money hereafter to pay off debts than to finish the library."

There was a widespread conviction, in which many in the legislature shared, that too much money was being expended on buildings, and that the institution should be put into operation without further delay. But Jefferson, Cabell, and their colleagues in the Board of Visitors were now at one as to the wisdom of completing the University before the sessions were begun; and these gentlemen were wiser than their critics in anticipating the ultimate judgment of Virginians on both these points. "I never in my life," wrote Cabell, "felt more deeply convinced on any subject than I am as to the soundness of the policy of going on with the buildings in preference to the plan of putting the institution into operation with half the buildings finished. The 
President of the College [William and Mary] and Judge Semple in a conversation with me a few days ago, candidly acknowledged the policy of our course in this respect. They observed that Virginians could never be pleased with anything on a small scale. Judge Semple adduced a fact, by way of illustration, which I was pleased to hear. Mr. John Tyler of Charles City, late member of Congress [afterwards President] was formerly opposed to the institution. In a trip which he made last year to the Springs he called and inspected the buildings, and the Judge assured me that $\mathrm{Mr}$. Tyler was so much impressed by the extent and splendor of the establishment that he had become an advocate of the University, and would have voted last winter, had be been in the legislature, for cancelling the bonds."

The bill passed February 5, I823, by a large majority-so large that it seemed Mr. Cabell had been unnecessarily alarmed. Surely a party which could muster a hundred and forty votes as against sixtynine may be described as very strong. The state of public sentiment as exhibited by the recent election had had its effect, and thus the asperities of the contest over the location were dying out. There was no hostility from Staunton. Chapman Johnson encouraged the loan; Sheffey and Baldwin showed a friendly disposition, the latter being especially cordial-but in spite of all this Cabell reiterates the conviction already expressed, "I think the best interests of the institution require that we should come here for no more money for buildings."

Nevertheless, he was alert for any opportunity to add to the University's building fund; and when

${ }^{7}$ Cabell to Jefferson, March 16, I822. 
the bill for rechartering The Farmers' Bank, having unconditionally passed the House of Delegates, reached the Senate, he straightway had it so amended as to require the payment of a bonus of $\$ 50,000$, which bonus was to go to the University of Virginia. The House refused to concur and a great stir resulted. Cabell was in danger, as he believed, of losing his popularity in his district. "I have been abused all about the town, and by a great portion of the Assembly. * * * I have scarcely seen the earth on which I walked for a month!" At the same time he confessed that soon after the contest had terminated public opinion and feeling toward him changed greatly.

The proposition for the remission of the debt due the Literary Fund, now \$180,000, was carried after a short and mild struggle, a result which liberated the sum of $\$ 10,800$ annually paid in interest.

The next movement for money was on the $\mathrm{Na}$ tional Government for $\$ 50,000$ on account of interest on a sum borrowed and used by Virginia for the national defense in the War of I8r2. The legislature had already consented to the application of this amount to the purchase of a library and apparatus for the University if the friends of that institution could collect it. Mr. Cabell went to Washington and in co-operation with Senator Barbour managed the affair so well that eventually the Federal Government paid the claim.

At the beginning of the legislative session of I 824-5 the friends of the University were disturbed by another peril. It was in the shape of an effort to remove William and Mary College to Richmond. "The proposition to remove William and Mary College to Richmond with all its present funds, and 
to add to it a medical school, is nothing more nor less than to remove the University also to that place; because, if both remain, there will not be students enough to make either worthy the acceptance of men of the first order of science. They must fall down to the level of our present academies, under the direction of common people, and our state of education must stand exactly where it is. Few of the States have been able to maintain one university, none two. Surely the legislature, after such an expense incurred for a real university, and just as it is prepared to go into action under hopeful auspices, will not consent to destroy it by this sidewise wind."

This utterance of Mr. Jefferson shows how grave the danger seemed to him. He suggested that if the proposition was decided affirmatively, the next question would be how the fund of the institution could be disposed of with the most advantage to the State at large. As this fund amounted to $\$ 100,000$ he regarded it as sufficient to put into operation the academies provided for in the Rockfish report, and so he advocated the division of the State into ten districts with an academy in each, each academy to be endowed with one-tenth of the capital of William and Mary.

At Cabell's request Jefferson drew a bill, which the former regarded as a powerful weapon in the fight, and well he might. Its provision that colleges should be established "at, or within, one mile, respectively, of William and Mary, Hampden-Sidney, Lynchburg, Richmond, Fredericksburg, Winchester, Staunton, Fincastle, Lewisburg and Clarksburg" was a strong appeal to at least seven of the ten localities named. Three would look upon it as 
hostile. Richmond had a powerful interest in the removal of William and Mary, to which Jefferson's effort at "dissolving and discontinuing" that institution would run counter. Williamsburg, which had lost the capital to Richmond, would oppose either removal or dissolution, while Hampden-Sidney naturally preferred unconditional endowment to change from a Presbyterian seminary to a State academy. But Staunton had long wanted to be the seat of government, and anything that increased the importance of the valley town or detracted from Richmond was counted as gain. Lexington was left out for Fincastle, a course which would avoid offending the friends of Washington College and more firmly attach Southwestern Virginia to the University party; and besides Fincastle, then the chief town of that section, was the home of General James Breckinridge, an influential friend of the University. In the selection of Fredericksburg, Winchester, Lynchburg, Clarksburg, and Lewisburg as sites of "colleges" the hand that drew the bill was guided by a like purpose of gaining friends by conciliation and the conferring of benefits.

At this juncture Mr. Cabell published in the Richmond papers a letter under the signature of "A Friend of Science," which accomplished all that it was expected to achieve with the bill, and the law was not proposed "A Friend of Science" advocated the discontinuance of William and Mary and the establishment of local colleges in ten districts in the State, naming most of the points at which they would be located. He indicated the feasibility of meeting the financial demand by the use of the moneyed capital of the old College, supplementing by an appropriation, and then contrasted the ad- 
vantages of ten colleges distributing their benefits all over the Commonwealth with those to flow from the maintenance, not of an added institution, but from the same one simply transferred from one site to another.

As the time for voting on the proposal to remove approached it became quite evident that it would be defeated in the House of Delegates. "We have the country completely on our side," Cabell wrote to Jefferson. "The idea of the country colleges will bear down all opposition." And it did.

The bill was defeated in the House by a majority of twenty-four, and William and Mary from that moment ceased to be a factor in the affairs of the University. The vote was taken early in February, I825, and on the 7 th of the next month the University of Virginia was in operation. 


\section{CHAPTER VI}

\section{RELIGION AND STATE EDUCATION}

Popular Discontent With Dr. Cooper's Appointment-JeFFERSON DEFENDS IT-PLAN FOR RELIGIOUS SEMINARIES NEAR THE UNIVERSITY-BOWDITCH AND TICKNORAmerican Professors-Francis Wal,ker Gilmer.

As soon as the plan for the first pavilion ${ }^{1}$ was agreed upon, yet two months before its cornerstone was laid, Mr. Jefferson induced the Visitors to invite Dr. Samuel Knox of Baltimore to accept the professorship of languages, belles lettres, rhetoric, history and geography. For this large undertaking he was to receive a fixed salary of five hundred dollars a year, and a contingent income from a fee of \$25 per student enrolled in his classes. Dr. Knox had abandoned business, and this honorarium did not tempt him from his retirement.

When the Visitors next met, October 7, I8I7, the cornerstone had been laid a day. Dr. Thomas Cooper, of Pennsylvania, was elected professor of chemistry, and requested to serve also as professor of law until that chair could be filled. Before Christmas, Cooper had engaged for the "physiological and law schools," and eighteen months later was "confirmed University professor of chemistry, mineralogy, natural philosophy, and also of law" temporarily. His income was to be made equal to $\$ 3,500$ per annum, a decided advance on the sum (\$I,Ooo) first decided on.

Mr. Jefferson evinced a decided partiality for this

\footnotetext{
${ }^{1}$ Pavilion VII, West Range.
} 
versatile Englishman, and perhaps his sympathy was quickened by the fact that for political reasons he was forced to flee "from the fires and mobs of Birmingham." That he was eminent in "several branches of science" and "a great chemist" as well as a lawyer of distinguished merits were reasons sufficient to excite Mr. Jefferson's imagination;' and that he did not overrate Cooper's merits is fairly presumed from his rapid rise as a lawyer and his incumbency of professorships in Dickinson College, the University of Pennsylvania, and the College of South Carolina.

But the appointment of Dr. Cooper was a mistake in more ways than one. It took place long before the institution was ready for his services. This could not be foreseen, perhaps, but in 1820 , when public opinion forced his resignation, it was certain that a year, at least, must elapse before classes could meet, and the finances did not justify the engagement of professors long in advance of actual service except for a very urgent reason. There was an apparent reason: the difficulty of procuring capable American scholars, and the importance of doing so when any "offered." But the obvious error was the failure to gauge Virginia sentiment in the matter of the religious beliefs Judge Cooper was known to entertain. Mr. Jefferson knew that he was a political refugee from England, and that he had offended English conservatism by his religious views. The general public of the State, however, was in ignorance of this until Dr. John H. Rice published in the Evangelical Magasine a review of Cooper's opinions, which he exhibited by extracts from the

\footnotetext{
${ }^{2}$ An honorable settlement was made by which Dr. Cooper received $\$ \mathrm{I}, 500$ for his loss, or cost.
} 
English scholar's writings. These seemed to show him to be a Socinian, and the Presbyterian divine abominated Unitarianism as much as he did the canons of the Establishment.

Mr. Jefferson lost patience with Dr. Rice, and in letters to Dr. Cooper criticised the Presbyterian sect, intimating that they desired their religious opinions established by law, and would be glad to monopolize the education of the country, and more of like tenor, all of which was very unjust, but very human. "For myself," he wrote to General Taylor, "I was not disposed to regard the denunciations of these satellites of religious inquisition, but our colleagues, better judges of popular feeling, thought that they were not to be altogether neglected, and that it might be better to relieve Dr. Cooper, ourselves, and the institution from this crusade. * * * I do sincerely lament," continues Jefferson, "that untoward circumstances have brought on us the irreparable loss of this professor whom I have looked to as the corner-stone of our edifice. I know no one who could have aided us so much in forming the future regulations for our infant institution; and although we may, perhaps, obtain from Europe equivalents in science they can never replace the advantages of his experience, his knowledge of the character, habits and manners of our country, his identification with its sentiments and principles and high reputation he has obtained in it generally."

Wise and just as he was habitually, Mr. Jefferson overlooked for the moment the fact that the Presbyterians, and in less measure perhaps, the Baptists, had made a State university a possibility by extending to the College of William and Mary, which they regarded as a seminary of the church, the hos- 
tility they felt, as Dissenters, to the Church of England, and bestowed on the University of Virginia all the friendship and service they withheld from the older institution. This same Dr. Rice had rendered signal service to Mr. Cabell in his legislative struggles for appropriations. It was in an article of his which appeared in a Richmond paper under the signature of "Crito" in advocacy of the University that the startling information was made public that Virginia was annually sending $\$ 250$,000 from the State to pay for the education of Virginians. Probably Dr. Rice knew that this money went out of the pockets of Dissenters who, for religious reasons, withheld their patronage from William and Mary; but whether he did or not, it was a fact, and in that fact the Dissenters found a reason for fostering a State university. Naturally they were unwilling that any sect should take charge of or exercise a preponderant influence in the University of the State. To Dr. Rice himself Mr. Nicholas Francis Cabell bears this testimony: "It is believed that Virginia did not contain within her broad limits, and among her most enlightened sons, one who was more truly attached to her soil and people, or who more ardently desired both the diffusion of knowledge among the masses and the improvement of education in its higher grades. His influence had been exerted by tongue and pen in behalf of the University while its fortunes were yet doubtful and when it most needed friends."

Mr. Jefferson in turn was assailed as an enemy of religion who would exclude all religious instruction from the University. His choice of an orthodox doctor of divinity-for such Dr. Knox was-for his first professor did not steady his critics or suggest 
that the venerable rector was not in quest of heretics to propagate a belief, but of scholars to teach "science in the highest degree." The aged philosopher made answer in his next report to the president and directors of the Literary Fund by saying that in conformity with the principles of the Constitution which place all sects of religion on equal footing, the Visitors had not proposed a chair of divinity, but had left "to every sect to take into their own hands the office of further instruction in the peculiar tenets of each." "It was not, however," he continues, "to be understood that instruction in religious opinions and duties was meant to be precluded by the public authorities as indifferent to the interests of society; on the contrary, the relations which exist between man and his Maker, and the duties resulting from those relations, are the most interesting and important to every human being and the most incumbent on his study and investigation. The want of instruction in the various creeds of religious faith existing among our citizens presents, therefore, a chasm in a general institution of the useful sciences; but it was thought that this want and the entrustment to each society of instruction in its own doctrines were evils of less danger than a permission to the public authorities to dictate modes or principles of religious instructions, or than opportunities furnished them of giving countenance or ascendancy to any one sect over another. A remedy; however, has been suggested of promising aspect, which, while it excludes the public authorities from the domain of religious freedom, would give to the sectarian schools of divinity the full benefit of the public provision made for instruction in the other branches of science. These branches 
are equally necessary to the divine as to the other professional or civil characters to enable them to fulfil the duties of their calling with understanding and usefulness. It has, therefore, been in contemplation, and suggested by some pious individuals who perceive the advantages of associating other studies with those of religion, to establish their religious schools on the confines of the University, so as to give to their students ready and convenient access and attendance on the scientific lectures of the University, and to maintain by that means those destined for the religious professions on as high a standing of science and of personal weight and respectability as may be obtained by others from the benefits of the University. Such establishments would offer the further and great advantage of enabling the students of the University to attend religious exercises with the professor of their particular sect, either in the rooms of the building still to be erected and destined to that purpose under impartial regulations as proposed in the same report of the commissioners or in the lecturing-room of such professor. To such propositions the Visitors are prepared to lend a willing ear, and would think it their duty to give every encouragement by assuring to those who might choose such a location for their schools that the regulations of the University should be so modified and accommodated as to give every facility of access and attendance to their students with such regulated use also as may be permitted to the other students of the library which may hereafter be acquired either by public or private munificence, but always understanding that these schools shall be independent of the University and of each other. Such an arrangement would complete the circle of 
useful sciences embraced by this institution, and would fill the chasm now existing on principles which would leave inviolate the constitutional freedom of religion, the most inalienable and sacred of all human rights, over which the people and authorities of this State, individually and publicly, have ever manifested the most watchful jealousy, and could this jealousy be now alarmed in the opinion of the legislature by what is here suggested the idea will be relinquished on any surmise of disapprobation which they might think proper to express."

This statesmanlike solution of the problem brought the rector out of the embroilment with much credit, and if "the religious community" had accepted the benefits proffered it would probably have been much better for the State and the church.

In October, I820, the year of Dr. Cooper's resignation, the Visitors instructed its committee of superintendence to enter into negotiations with Nathaniel Bowditch, of Salem, and George Ticknor, of Boston, to be professors of the University, the compensation to be apartments, a salary of $\$ 2,000$ a year, and a fee of \$ro for each student engaged. If salary and fees did not amount to $\$ 2,500$ in either the first, second, or third year, the deficiency was to be paid out of the funds of the University.

Mr. Bowditch was a remarkable man. He was the son of a cooper, and left school at ten years of age to work in his father's factory, where he remained until he went to sea in a very humble capacity. In time he rose to the highest post in his calling, and published superior technical works on navigation. Always an enthusiastic and persistent student, he became eminent in mathematics, one of 
the greatest of his achievements being his translation of Laplace's great work. A dozen years before the University of Virginia solicited his acceptance of a professorship, he had declined a chair at Harvard and afterwards one at West Point, a very remarkable record for a self-taught man.

Mr. Ticknor, during a visit to Monticello in I8I5, had won the affection and admiration of $\mathrm{Mr}$. Jefferson. To no other of his correspondents did the ex-President write in a strain of more unreserved compliment. Three years before the committee of the board invited Ticknor to the University, he had written him of his ambition to found a great seat of learning, to do all that he could, if it should not be his good fortune to do all that he wanted to accomplish for his State. In 1818 he wrote again on his favorite theme, and once more discloses his desire to have Ticknor in his faculty. "Many are the places which would court your choice," he said, "and none more fervently than the college I have heretofore mentioned to you." But Ticknor had other plans, and so his name and fame are not linked with the history of the University.

The refusal of these scholars to come to Virginia saved the young institution from another sectarian assault, because those to whom Cooper's appointment was offensive were displeased with the choice of these eminent sons of Massachusetts. The religious community was uneasy on the score of their religious beliefs, but what the precise basis of dissent was nobody would have the patience to enquire at this day.

In point of time the European professors were the first engaged, but it is convenient to conclude this chapter with a reference to the American scholars 
who accepted chairs in the University. Of these Francis Walker Gilmer was the first solicited, but Tucker was the first to accept. "Mr. Madison and myself think with predilection of George Tucker, our member of Congress," Mr. Jefferson wrote Senator Cabell in December, I824, in connection with the professorship of moral philosophy. "You know him, however, better than we do. Can we get a better? Will he serve?" Tucker had been in Congress six years, where he had won distinction as a debater and constitutional lawyer. Higher political honors were possible, no doubt, but the literary life attracted him as it has many who have chosen the profession of law, and although he hesitated, and asked for time to consider, he eventually accepted the chair, and discharged its high duties for twenty years. He had been educated at William and Mary, arriving at Williamsburg about I795 from one of the Bermuda islands, where he had been born under the British flag. In literature he wrought in the field of the historian and sociologist in a manner and with a success that justified the "predilection" of Jefferson and Madison. The Visitors never wavered in their conviction that the chair of law and politics and that of ethics or moral philosophy must be filled by Americans, because these subjects were pre-eminently those that give tone and direction to the public mind on the most important subjects that can occupy the human understanding. ${ }^{3}$ Into these they were resolved there should be no possible opportunity to intrude the teaching of the moral or social philosophy of Europe, and certainly the interjection of alien theories of society or gov-

${ }^{3}$ Cabell to Jefferson, April I6, I824. 
ernment was impossible under the headship of George Tucker.

Dr. John Patten Emmet, engaged to teach natural history and chemistry, was regarded by Mr. Jefferson as representing the natural sciences in his faculty. He was found in New York while on a visit from Charleston, South Carolina, where he had settled for the practice of his profession, after a fruitless quest in Europe for an incumbent of this chair. While he was a native of Dublin, born in r797, and a nephew of the Irish orator, he had spent nearly all his life in America. He was educated chiefly at West Point, and it was a West Point professor who recommended him to the University, having himself declined the offer. ${ }^{4}$ Dr. Emmet was the first professor to exercise the authority of chairman of the faculty. ${ }^{5}$

But Francis Walker Gilmer remains the most interesting, in a pathetic way, of those first selected as professors. More distinctly than any of his proposed colleagues he was a son of the soil. His heritage was that of a Virginian true to type-loyal to the home in which he was born, and to the history and traditions of his State. At times he showed himself touched with the infirmity of a cynic wit, which was amiable oftener than bitter; and distinguished by gifts of a high order and a scholarship so broad that it justified Mr. Jefferson's characterization of him to Minister Rush as "the best educated subject we have raised since the Revolution, highly qualified in all the important branches of science."

Gilmer was born at Pen Park, near Charlottesville, in 1790 , the son of Dr. George Gilmer, the

- Professor Torrey.

'George Tucker was the first elected to that office. 
descendant of a Scotch family whose ancestral home was Craigmillar Castle, near Edinburgh. As a child of five he had probably seen the yet unknown young Maryland lawyer, William Wirt, when he came to claim his sister, Mildred, as his bride. $\mathrm{He}$ was irregularly and almost self-taught until he entered William and Mary, but Wirt bore testimony many years after to the extent and variety of his information, while admitting its chaotic character. It was not long, however, before he was "as remarkable for the digested method as the extent and accuracy of his attainments." $\mathrm{He}$ impressed the president of the college so favorably that he was offered the ushership of the grammar school connected with the institution. This was declined and the young alumnus accepted Wirt's invitation to read law with him in Richmond. Wirt had attracted to himself some of the most gifted and distinguished of the literary, social, and official coteries of the capital. From this time until he was invited to become professor of law Gilmer devoted himself alternately to society, the study and practice of law, the investigation of social and economic questions, the writing of essays, and the study of natural sciences under the inspiration of the Portuguese scholar, the Abbe Correa de Serra. ${ }^{6}$

\footnotetext{
${ }^{6}$ How this learned man impressed Gilmer may be learned from a letter in which, among other extravagant things, he said: "He is the most extraordinary man now living, or who, perhaps, ever lived. None of the ancient or modern languages, none of the sciences, physical or moral, none of the appearances of earth, air or ocean, stand him any more chance than the Pope of Rome, as old Jouett [who kept the Eagle Hotel in Charlottesville] used to say. I have never heard him asked a question which he could not answer, never seen him in company with a man who did not appear to be a fool to him, never heard him make a remark which ought not to be remembered. He has read, seen, understands and remembers
} 
There is a reason to believe that $\mathrm{Mr}$. Jefferson had approached Gilmer on the subject of the law professorship as early as the late fall of $1823 .^{7}$ The purpose in establishing this chair was to contribute to the strength of American citizenship. His school of law and politics he sought to base on ethics taught by an American scholar and upon natural science and the ancient and modern languages associated with history and literature, ancient and modern. "All the arts and sciences were to be tributary to the education of American citizens for their highest duties." It was a flattering confidence which the old philosopher reposed in Gilmer, and the latter was disposed to assume the office, and yet he hesitated. Financially considered the post, honorable as it was, offered no temptation, for he had been reasonably successful at the bar. There was nothing to be gained in the matter of leisure, for the certain demands of his chair would leave no time for literary employments. There were good reasons for requesting time for mature reflection, but the truth is Gilmer seems to have been averse to a fixed scheme of life. As early as I8I4 he had thought of settling in Lexington, Kentucky, but abandoned that purpose, perhaps because it involved separation from his mother. Winchester next engaged his thought, but he was in no hurry, and more than six

everything contained in books, or to be learned by travel, observation, and the conversation of learned men."

In a letter to Gilmer in 1820 the Abbé made this remarkable statement: "You will, I hope, live long, my dear friend, and you will every day see with your eyes what difference exists between the two Philosophical Presidents [Jefferson and Madison] and the whole future contingent series of chiefs of your nation."

${ }^{7}$ Trent, English Culture in Virginia, p. 48. 6 
months later we find him on the way to Philadelphia with the Abbe Correa. The next summer he reached Winchester, and hung out his shingle, but the Abbe happening along the shingle was taken down, and together the old and the young enthusiasts for nature set out to botanize in the Carolinas. Gilmer returned to Winchester, and remained for two years. There he found three good friends, Judge Holmes, Congressman Tucker, and Chancellor Dabney Carr, son of Jefferson's sister, the same he refused to appoint professor of law for the reason that he was his nephew. ${ }^{8}$

Although successful at Winchester, Gilmer wished a wider field and went to Baltimore to settle; but finding some obstacle in the way, although his friends thought it removable, he decided on Richmond as the arena of his legal performances, was not satisfied, went back to Baltimore, and returned to Richmond. Still looking abroad, he sought the secretaryship of the territory of Florida, but President Monroe was not willing to assist in "burying him." The presidency of William and Mary seemed possible to him, but Mr. Jefferson hoped he was not thinking of shutting himself "behind the door" of that institution. There was a suggestive similarity in the attitudes of Monroe and Jefferson. Then Gilmer steadied, and for the next five years he was in Richmond, pursuing law and literature, the latter to such good purpose that Pictet, the head of the University of Geneva, translated his "Theory of

\footnotetext{
${ }^{8}$ In the course of the trusts which I have exercised through life, with powers of appointment, I can say, with truth and unspeakable comfort, that I never did appoint a relation to office, and that merely because I never saw the case in which some one did not offer or occur better qualified."-Jefferson to Cabell, February 23, I824.
} 
the Natural Bridge," maintaining it to be the only scientific solution. He was loth to give up scientific and literary employments which were winning him European reputation.

Through it all, and influencing his life more, perhaps, than appears in his letters, he lived under the suffering and discouragement of physical weakness and debility. Wirt frequently admonished him in merry words, but evidently with a heart made serious by Gilmer's precarious health.

Gilmer consented to consider further the professorship he had once declined, and when he sailed for Europe in May, 1824, the matter was still under advisement. In a letter written in Edinburgh in August of that year, and addressed but never sent to his bosom friend, Chapman Johnson, a member of the Board of Visitors of the University, he indicated his intention to accept under conditions which he named. As he is writing to a loyal friend he feels at liberty to indulge in a little sarcasm at the expense of the pavilions: "If you would make me president or something with the privilege of residing anywhere within three miles of the Rotunda it would be a great inducement, but to put me down in one of those pavilions is to serve me as an apothecary would a lizard or beetle in a phial of whiskey set in a window and corked tight. I could not for fifteen hundred dollars endure this even if I had na labor."

The voyage from Europe shattered a constitution never strong. He recruited somewhat, but his health remained precarious. In this condition, according to Mr. Wirt, he decided to retreat from the severe labors of his profession, and therefore accepted the professorship of law in the University of Virginia. 


\section{CHAPTER VII}

\section{GILMER'S MISSION TO EUROPE}

EFForts to Procure AmERTCAN ProfESSORS-Comments of John Adams and General Blackburn-GILMER EnGAGES PROFESSORS IN EUUROPE-HOMEWARD VOYAGE.

At the meeting of the Visitors of the University in March, I8I9, a little more than a month after the chartering of the institution, a standing order was entered on the minutes in these words: "Considering the importance and the difficulty also at this time of procuring American citizens of the first order of science in their respective lines to be professors in the University, the committee of superintendence are hereby jointly instructed and authorized, should any such offer, not to lose the opportunity of securing them to the University by any provisional arangement they can make within the limits of the salary and tuition fees before stated." For more than five years Mr. Jefferson and his colleagues had tried to find and engage American scholars of "the first order of science," but few were found, and none engaged. The hue and cry that greeted the appointment of Dr. Cooper lost to the University a man who proved a tower of strength to the College of South Carolina. Mr. Ticknor was not available, and Mr. Bowditch declined the honor tendered him by Virginia, and also those offered by Harvard and West Point; and so, when at last the University was ready for its faculty, there were no professors to fill its chairs. Constant vigilance having failed to yield any in America, there was noth- 
ing to do but send to Europe. Accordingly, on the morning of May 8, 1824, Francis Walker Gilmer sailed out of New York on the packet Cortes commissioned to engage a certain number of professors of the required eminence in science from among the scholars of Oxford or Cambridge in England, or from among those of Edinburgh in Scotland.

More than one newspaper denounced the proceeding with unconcealed indignation: "Mr. Jefferson might as well have said that his taverns and dormitories should not be built with American bricks," said one, "and have sent to Europe for them, as to import a group of professors." "Mr. Gilmer could have fully discharged his mission, with half the trouble and expense, by a short trip to New England." "Or, we may be permitted to add, by a still shorter trip to Philadelphia," said another, concluding: "This sending of a commission to Europe to engage professors for a new university is, we think, one of the greatest insults the American people have received."

Even John Adams disapproved: "Your University is a noble employment in your old age, and your ardor for its success does you honor; but I do not approve of your sending to Europe for tutors and professors. I do believe there are sufficient scholars in America to fill your professorships and tutorships with more active ingenuity and independent minds than you can bring from Europe. The Europeans are all deeply tainted with prejudices, both ecclesiastical and temporal, which they can never get rid of. They are all infected with Episcopal and Presbyterian creeds and confessions of faith. They all believe that great principle which has produced this boundless universe, Newton's universe, 
and Herschell's universe, came down to this little ball to be spit upon by the Jews. And until this awful blasphemy is gotten rid of there never will be any liberal science in the world.",

General Samuel Blackburn, an old Federalist, scarcely predisposed to favor any scheme of $\mathrm{Mr}$. Jefferson's except on its merits, defended the policy of sending to Europe for professors, and his picture of the educational conditions of that day is at least informing: "From whence, then, are those professors to be had? At home? Impossible! When upon a late vacancy a president was wanted for Princeton, one of the most venerable institutions in the Union, with what difficulty was it filled! Was it not offered to different gentlemen of our acquaintance who appeared to have no very imposing claims to such an appointment? Did not one of those gentlemen refuse it, and afterwards accept the direction of a college much nearer home, to be sure, but much less distinguished in the United States for antiquity or the number of great men formed therein. Is it not also a fact well known that another professorship in that distinguished institution, long esteemed the cradle, the nurse of science in this western world, now is, and for a considerable time has been, filled by one of the alumni of Washington Academy, now College, of very modern date. It would seem, then, from these appointments that the range of election in the United States had been rather limited than extensive. But let me ask, sir, will it follow that because we may be able to fill a few professorships in some colleges in this and other of the United States that we have material at home to furnish ten professorships for the University of Vir-

${ }^{1}$ Letter to Jefferson, January 22, I825. 
ginia-and those best qualified to establish the reputation of the institution at home, and give it celebrity and eclat throughout the Union and the world? This cannot be asserted, will not be believed. Those professors then, or a majority of them, must be obtained from Europe, men who have spent, not some five or six years only in the acquisition of knowledge, probably at some country school, obscure academy, or college, in the western wilderness, but who, if not born to, have at last been brought up and spent their lives in, deep retirement and profound application. And yet I cannot conceal my predilection for American teachers, and American (especially Virginian) manners, and the fear that foreign professors may introduce into our institution foreign opinions and customs alien to the simplicity of republican manners adopted by our government. My only apology is the necessity of the case, and a belief that perhaps a single importation will be sufficient, and enable us in future, by proper attention to domestic production, to depend for further supplies on our own manufactories, relying, too, on the native firmness and independence of the Amercian character, seldom disposed to sacrifice convenience to show, or substance to shadow."

Gilmer disembarked at Holyhead, and hurried through Wales to Liverpool, where he arrived on the 6 th of June. Then began a very active itineration about England and Scotland in an earnest effort to discharge the mission entrusted to him. Many accidents, as he wrote to Dabney Carr, conspired to delay him. At that season of the year "no man in England is where he ought to be except per-

\footnotetext{
${ }^{2}$ Remarks, in Committee of the Whole of the House of Delegates of Virginia, January I6, I824.
} 
haps those of the Fleet and of Newgate." Every little country schoolmaster, "who never saw a town," had gone to the country, that is, "to Scotland to shoot grouse, to Doncaster to see a race, or to Cheltenham to dose himself with that vile water."

From Liverpool he went to Hatton to call on Dr. Samuel Parr, but the venerable friend of Christopher North had gone to Shrewsbury. A later visit was more successful, and Gilmer spent two days with the old scholar, whom he described as "the greatest now in existence." He took great interest in the young lawyer's mission, and was socially exceedingly obliging, going with him to visit Guy's Cliff and Kenilworth, where they dined with a friend of Dr. Parr's.

In London he presented his letter to Richard Rush, United States minister, and through his good offices was provided with letters from Lord Teignmouth and Mr. Brougham to influential persons in Cambridge, Oxford, and Edinburgh. In London, too, he concluded an engagement with Dr. Blaettermann in pursuance of instructions from Mr. Jefferson, to whom Blaettermann had been strongly recommended by George Ticknor. His visit to Oxford and Cambridge seemed at the time unprofitable, but at the latter place he met, in the rooms of the poet Praed, Thomas Hewitt Key, a master of arts of Trinity College, whom he afterwards engaged as the first professor of mathematics. Gilmer spoke in at least three letters of the cordial treatment he received at Cambridge. The manner of his reception, he said, had softened his profound respect and veneration for the most renowned University in the world into a warm esteem for all connected with it, from Dr. Kay, then Bishop of Bristol, and Dr. 


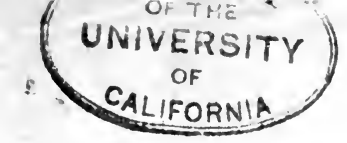

THE UNIVERSITY OF VIRGINIA

Davy, to whom he bore a letter from Brougham, down to the undergraduates, all of whom vied with each other in the profusion and delicacy of their civilities. He dined half the days of his sojourn in the Hall of Trinity College, the most famous of all, and was delighted with the urbanity and good breeding of the fellows.

Gilmer had some intention of going to Germany to accomplish his mission, and thought favorably of Gottingen, but postponed decision until he had visited Edinburgh. His reception in the Scottish metropolis was exceedingly flattering. More invitations reached him than he could accept. He dined with "the famous Professor Leslie, and he was surrounded by his meteorological machines." John A. Murray, the distinguished lawyer and associate editor of the Edinburgh Review, showed him many civilities, and he seems to have been thrown with Jeffrey, and to have won the good opinion of his American wife, who called him "the most popular and attractive American ever seen in Edinburgh," although Washington Irving had been there just seven years before.

Gilmer had gone to Scotland sanguine of getting at least a professor of anatomy, and with some hope of a professor of natural history and natural philosophy, and he sought them with energy, but his diligence went unrewarded. In three weeks he was back in London. There Key brought to his attention George Long of Liverpool, whom he had known at Trinity, and a correspondence ensued. Dr. Birkbeck ${ }^{3}$ recommended for professor of anat-

${ }^{8}$ Dr. George Birkbeck, distinguished as a physician and for his interest in education, in whose honor the institute of that name in London was called. He was one of the founders of the University of London. 
omy a young London physician, already favorably known as a physician and as a writer on medical subjects. This was Dr. Robley Dunglison, who became the first professor in the medical department of the University of Virginia, of which he is regarded as the founder. Charles Bonnycastle, a son of a distinguished English mathematician, engaged for natural philosophy, thus completing the English faculty which Mr. Gilmer induced to go to Virginia.

Gilmer was eager to get back to Virginia. "For myself," he wrote to his friend Dabney Carr, "I shall return to the bar with recruited health and redoubled vigor. I shall study and work and speak and do something at last that shall redound to the honor of my country. My intercourse with professional and literary men here has fired again all my boyish enthusiasm, and I pant to be back and at work. The library of the University and my intimacy with the professors will now make even my summer holidays a period of study." Another note was struck in his next letter to Judge Carr, as we shall see. He took passage from Cowes on the packet Crisis, and five weeks later, in a letter from New York to his "most dear friend," he gave a vivid and, in view of the sequel, pathetic description of the voyage :

"Having concluded all my arrangements in England much to my satisfaction, I thought to return with triumph to the light and bosom of my friends. Fatal reverse of all my hopes! here am I chained like Prometheus, after 35 days of anguish at sea, such as man never endured. I hold seasickness nothing, I laughed at it as I went over-but to have added to it a raging and devouring fever aggravated by want of medicine, of food, of rest, of attendance, 
and the continued tossing of the 'rude, imperious surge,' form a combination of miseries not easily imagined, and never before, I believe, exhibited. I am reduced to a shadow, and disordered throughout my whole system. My liver chiefly, it is thought. Among other symptoms, while I was in mid-ocean, a horrible impostumation, such as I supposed only accompanied the plague, in the form of anthrax or carbuncle, appeared on my left side, low as I was. I neglected it until it was frightful-it required lancing-but not a man could I get to do it-some were sea-sick-others indifferent. I called one who said he was a Doctor, and desired him to cut it open-we had no lance, no scalpel, no knife that was fit, and finding him a timid booby whose hand shook, I took with my own hand a pair of scissors I happened to have, and laid open my own flesh. *** We had no caustic, and I had to apply bluestone, which was nearly the same sort of dressing as the burning pitch to the bare nerves of Ravaillac-yet I am no assassin. All the way I repeated,

'Sweet are the uses of adversity,' \&c.

"I must turn this to some account. In this world I cannot, but I 'lay the flattering unction to my soul' that he who suffers well never suffers in vain. Such is the martyrdom I have been enduring for the Old Dominion. She will never thank me for it, but I will love and cherish her as if she did." 


\section{CHAPTER VIII}

\section{THE FACULTY OF I 825}

ARrival of Professors-Their Reception in Richmond-Mr. JEFFERSON'S WEICOME-BRIEF BIOGRAPHIC INFORMATION FIRST WINTER IN VIRGINIA-GLIMPSES OF SOCIAL, LIFE, of Faculty and Students-American Professors.

Long and Blaettermann were the first of the European professors to arrive, reaching New York while Gilmer was still the object of the kindness of the Emmets. After paying their respects to the young Virginian they proceeded to Richmond, and thence to Charlottesville. In Richmond they saw Senator Cabell, who was using his great powers of persuasion to prevent the removal of William and Mary to that city.

Key, Dunglison, and Bonnycastle were not so fortunate. The English coast was swept by terrific gales at the time they were expected to sail in the Competitor, "an old log," and for a long time it was feared they were lost. Cabell and Gilmer did all they could to allay Mr. Jefferson's distress and to conceal their own uneasiness. Late in January the Senator saw in a Norfolk paper that the Competitor was still in Plymouth Harbor on the 5th of December, after the storm which it was feared had destroyed her. He posted the news at once to $\mathrm{Mr}$. Jefferson, who replied: "That they were safe raises me from the dead, for I was almost ready to give up the ship." But the ship, which seems to have been a wretched craft in which to tempt the sea, reached Norfolk on the Ioth of February, 1825, and 
Gilmer sent the glad tidings to his venerable chief. Dr. Dunglison also dispatched a letter to him as soon as they had disembarked.

The Englishmen proceeded to Richmond by boat. There they were welcomed by ex-Governor Thomas Mann Randolph and his son (Mr. Jefferson's grandson) Thomas Jefferson Randolph, who had been sent down from Charlottesville to arrange for the journey to the University. They were the guests of the distinguished lawyer Chapman Johnson for at least a part of their stay in the capital, and a letter of the time, written in the freedom of private correspondence, gives an interesting glimpse of an evening at Mr. Johnson's. "In a short time the rooms began to fill; we had quite a squeeze. The grave seems to have given up the dead, for there came ladies whom I have not heard of being out before for years to see the English people." The cultivated Virginia ladies were amazed to find that Mrs. Key and Mrs. Dunglison, fresh from England less than a year after the death of Byron, had not heard of him or Sir Walter Scott! Still, with native good sense, they awarded to these young English wives much credit-for being gentle, sensible, and quite pretty.

They did not tarry long at Richmond, knowing Mr. Jefferson was impatient for their arrival at Charlottesville. Soon after that event the venerable statesman presented himself and welcomed them "with that dignity and kindness for which he was celebrated." At the University they found Dr. Blaettermann and Professor Long already domiciled-the former in Pavilion IV, the second house on East Lawn, and the latter in Pavilion V, the

\footnotetext{
${ }^{1}$ Alumni Bulletin of the University of Virginia, III, 5.
} 
third on West Lawn. Professor Key and his bride began housekeeping in Pavilion VI, the third residence on East Lawn, and Dr. and Mrs. Dunglison - for the professor of medicine and anatomy also brought out a bride-set up a happy establishment in Pavilion X, at the southern end of East Lawn. Mr. Bonnycastle, a diffident bachelor, lived in utter loneliness in the Pavilion between them, No. VIII. It has been inferred that Mr. Jefferson thought his professors would remain single and occupy bachelor apartments on the second floor of his pavilions, but he probably confidently expected what happened, for he was a very wise old gentleman. However that may be, three of his five first professors moved into the temples and theatres on the Lawn with wives and the remaining ones-Long and Bonnycastle-brought young Virginia brides to their firesides. It was not long before these young matrons had banished the classes from their homes, and converted the large lecture-halls into drawing-rooms.

The first session began March 7, I825, with the following schools open on that day:

Ancient languages, Professor George Long.

Modern languages, Professor George Blaettermann.

Mathematics, Professor Thomas Hewitt Key.

Natural philosophy, Professor Charles Bonnycastle. lison.

Anatomy and medicine, Professor Robley Dung-

Thus these foreigners were the only professors present on the opening day of the first session, for Dr. Emmet was not actually elected until March 4, and Mr. Tucker was making a tour of the spring courts in his district to announce to his constituents 
his decision to withdraw from Congress and be a professor in Mr. Jefferson's University. Mr. Gilmer, professor of law, was sick in Richmond.

The first recorded official act of this faculty took place at a meeting "holden at the house of Professor Key" on the evening of April I2, when the members present were Professors Dunglison, Bonnycastle, Blaettermann, Long, and Key. These foreigners gracefully elected Mr. Tucker to the highest executive office, that of chairman of the faculty, and resolved that until his arrival Dr. Emmet, the other American member, who was daily expected, "be chairman." As one looks back over the sometimes terrible responsibility of that office one sees that the reward of these bright young men was as certain as if they had conferred their first honors in obedience equally to a sense of what was appropriate and a marvelous foresight of what they would escape. Perhaps, after all, there had been an intimation from Mr. Jefferson that Mr. Tucker's age-he was fifty-and Mr. Emmet's experience as an acting assistant professor in the great military academy at West Point, indicated them as probably the best prepared to assume successfully the discharge of the difficult duties of chairman.

Did Mrs. Dunglison and Mrs. Blaettermann and the Blaettermann children drop in to spend with Mrs. Key the time their husbands were devoting to University affairs in this first faculty meeting? There was nobody, save servants, to leave them with at home. It is easy to imagine the ladies having a good talk about things at home in old England and wondering whether the Tuckers and Dr. Emmet would prove agreeable folk.

Who will say that this first winter in Virginia 
was not a little monotonous even to those young residents on the Lawn for whom the honeymoon was still in full splendor? No doubt Mrs. Randolph descended from Monticello to visit the young wives, and the Carrs, Garretts, Southalls, Trists, and other families in reach of the University contributed whatever they could socially to their entertainment. But Charlottesville was a mere village, huddled around the court-house, which was as yet the only place of worship; the market was poor, and the only considerable town-Richmond-was nearly a hundred miles away. The University itself was unpleasantly new and smelling of paint, and its chief building, the Rotunda, still unfinished. The grounds, recently graded and parts of them doubtless still undergoing change, were raw, treeless, and uninviting to English eyes. And it would deprive the picture, as it was presented to those people, of much of its uninviting shadow if we were to overlook the fact that long, weary weeks were required for a letter to travel from London to Charlottesville.

Professor Long especially spent a dreary Christmas, his case being worse than that of his colleague, Dr. Blaetterman, the only other professor arrived at that date, as he was wifeless and alone, with only his black servant Jacob to look after his household. "I dined with Mr. Jefferson last Monday," he wrote Francis Gilmer. "He was in good health, but, like all of us, very uneasy about the delay of our friends. I do not yet, being acquainted more fully with all the circumstances of the case, entertain any apprehension about their safety, but I regret, both for the University and my own personal comfort, that they were so foolish as to embark in an old log. The people in Charlottesville, having nothing better 
to do, amuse themselves with inventing stories on this unfortunate subject. Almost every day, from undoubted authority, I am informed that the professors have arrived; a few hours after I had received your letter a man very gravely assured me the professors were at that moment in Richmond." To add to his discomfort, a heavy snow late in January made it inconvenient to go abroad. His intercourse was confined to the family of Mr. Gray, the first occupant of the University hotel at the south end of West Range, with whom he took his meals, but even within this limit he found compensation. In the ensuing session, the students who were "dieted" at this hotel, and who liked the genial little Englishman very much, were not slow to perceive an interest in Mrs. Harriet Sheldon, Mr. Gray's widowed daughter, and did not hesitate jestingly to intimate that it was reciprocal. They soon conferred on Professor Long the title of Colonel, probably in jocund allusion to his stature, which was below the medium, and they teased Mistress Harriet by perverting the well-known couplet into

"Man wants but little here below, But he wants that little Long.

The Colonel led Mrs. Seldon to the altar, and it gives us a pleasant glimpse of the early days of the University to be told that when she descended to be married she was "more beautiful than you can conceive," that she was dressed with simplicity and admirable taste, that she behaved during the ceremony and throughout the evening with the most becoming dignity, and that the Colonel was matchless in beauty and grace and engaging conversation. 
Mr. Long remained at the University more than three years, and was then released at the urgent appeal of Lord Brougham in a letter to the rector, James Madison. In that brief time he established the school of ancient languages firmly in the confidence and respect of the learned world, and won from his pupils the highest tributes of admiration. Among these is a balanced and judicial appreciation by Dr. Gessner Harrison, one of his first students and his successor, chosen upon his own urgent nomination: A man of marked ability and attainments, thoroughly trained in the system of his college, having a mind far more than most men's scrupulously demanding accuracy in the results of his inquiry, and scouting mere pretension, he aimed and was fitted to introduce something better than what then passed current as classical learning. Although he had as yet little knowledge of comparative philology, and would hardly be said to have cultivated the science of language with the enlarged spirit of philosophy which pervades his writings, his uncompromising exactness and his masterly knowledge of his subject inspired his students with the highest conceptions of a true scholarship. ${ }^{2}$

Dr. Harrison also spoke well of Professor Blaettermann as giving proof of extensive acquirements and of a mind of uncommon natural vigor and penetration. In connection with the lessons in German and Anglo-Saxon he afforded his students much that was valuable in comparative philology also. Dr. Blaettermann's accent betrayed his German origin, but that, as Mr. Gilmer said, "we are obliged to encounter every way, as there are no profound

\footnotetext{
${ }^{2}$ Gessner Harrison in Duyckink's Cyclopedia of American Literature, II, 730 .
} 
English professors of modern languages." There was no question of his accomplishments as a linguist, and annually during his connection with the University the catalogue announced: "The languages taught in this school are the French, Spanish, Italian, German, and Anglo-Saxon; and if desired will also be taught the Danish, Swedish, Hollandish, and Portuguese languages;" and this at a time some years before any American university had done more for a modern language than to license an occasional itinerant French dancing-master to give lessons in his native tongue. He won the admiration of a distinguished member of the Board of Visitors by his extensive knowledge of AngloSaxon, that branch of English being a hobby with the Visitor, as it had been with Mr. Jefferson. ${ }^{3}$ Dr. Blaettermann retired from his chair in $1840 .^{4}$

Gilmer wrote and spoke of Thomas Hewitt Key with more enthusiasm than of any other of the professors he engaged in England. He met him under pleasant auspices, in the room of the young poet Praed at Cambridge, and was himself the first American Key had ever known. The young master of arts of Trinity held views on the sciences highly

'The original manuscript of Mr. Jefferson's "Essay Towards Facilitating Instruction in Anglo-Saxon and Modern Dialects in the English Language, for the use of the University of Virginia," is preserved in the University Library.

- After Dr. Blaettermann retired from the University he lived on a farm east of Charlotttesville, and a few years after his removal he was found dead in the snow between his own home and Mr. Huckstep's. Mrs. Blaettermann, an English woman of fine attainments, taught a private school at Ivy House, east of the present University Park, on West Main street. The building was destroyed by fire in 1882 . The family probably moved to Kentucky, for in 1896 a son of Dr. Blaettermann was superintendent of public schools of Mason County, with his office at Maysville. 
satisfactory to Gilmer and his employer. "I have already said," he wrote to his American friend, "that I am fondly attached to the sciences, and the strength of that attachment is proportional to each as it appears to me calculated to advance the interests of mankind. In the University of Cambridge I have often thought that this object is too much lost sight of; and that the great body of talent in that seat of knowledge is frequently directed to points of comparatively minor importance, and thus in a great measure thrown away, whilst it might be employed in a manner so highly beneficial both for England and the whole world." This rings harmoniously with Mr. Jefferson's keynote- "All the branches of science useful to us and at this day."

$\mathrm{Mr}$. Key was one of the party of three professors who crossed in the Competitor. The tall, slender Englishman, by his humor, seems to have enlivened that monotonous voyage for all except the stupid captain, one Godby, for whom the passengers had a full measure of contempt, and whom he made the butt of his jokes. At the University he speedily won recognition for his talents and attainments, and began the careful study of the Latin, which he continued all his life, and through which he was destined to win his chief distinction as a scholar. ${ }^{5}$ During Professor Long's return to England in the summer of 1825 to receive his fellowship at Cambridge he taught his classes in Latin and Greek in addition to his own in mathematics. He was a faithful and competent instructor, and the University released him with deep regret in 1827 to return

${ }^{5}$ Jefferson and the University of Virginia, United States Bureau of Education Circular of Information No. I, I888, page 2I8. 
to London, the climate of Virginia proving injurious to his health. ${ }^{\circ}$

Charles Bonnycastle was the son of the selftaught mathematician, John Bonnycastle, long a master in that subject at the Royal Military Academy at Woolwich, England, of whom Leigh Hunt spoke with a characteristic blending of shrewd criticism and amiable appreciation. Professor Bonnycastle's biographers emphasize his reputation for shyness and taciturnity beyond the truth, no doubt, for his miscellaneous writings ${ }^{7}$ indicate traces of a genial humor, and Professor Key mentions him as his abettor and assistant in the jokes played on the sailor Godby. His intellectual eminence, like that of all the foreigners in the faculty of 1825 , was never in dispute, and many of his pupils would have contended that in the matter of mind he was pre-eminent in that distinguished group of scholars. At home and in society, however, his habits of deep reflection gave ground for the belief in his taciturnity. In moments of abstraction he was indifferent to what was passing around him, and he would sit in the midst of his playful children perfectly unconscious of their bewitching gambols. ${ }^{8}$

Professor Bonnycastle died in 1840 , greatly lamented, if the contemporary notices of his death can be relied on as correctly measuring the feeling ex-

- Of his distinguished career in his own country the inquirer may learn from the notice of his life prepared by Prefessor Long, his colleague in Virginia and also at the University of London, in Proceedings of the Royal Society of London, No. I60.

"See several articles in the Literary Museum, published at the University by the professors, I829-30, signed P Z.

${ }^{8}$ Southern Literary Messenger, VIII, 5I. The late B. B. Minor, one of Mr. Bonnycastle's students, contributed this article. 
tribute, and the students, in resolutions passed at a mass meeting, warmly eulogized his virtues. ${ }^{8}$

"The professor of anatomy, etc., is a very intelligent and laborious gentleman, a Dr. Dunglison, now of London, and a writer of considerable eminence on various medical and anatomical subjects." In this one sentence of his letter to Jefferson, in the fall of 1824, Gilmer summed up the whole character of Dr. Dunglison as well as any one could have done, in like limits, after the doctor's life was rounded to its close. His career as a medical writer, begun immediately after his return to London with his degree from Erlangen, he continued at the University of Virginia, at the University of Maryland, and after he had gone to Philadelphia as professor of the institutes of medicine in Jefferson Medical College, so industriously that he had published about twenty volumes before his death in I869. The works written at the University of Virginia-his Human Physiology and his Medical Dictionary-were the most important and are still referred to with respect, although necessarily much out of date.

Dr. Dunglison was engaged for the University at a time when there was no intention to establish immediately a school of medicine for the education and training of physicians. The teaching of medicine was to proceed on historical lines, with explanations of its "successive theories" from Hippocrates down, for the simple purpose of affording such information as the mass of educated people would want for the sake of culture. Mr. Jefferson seemed to think

${ }^{\circ}$ Mrs. Bonnycastle, who was a Miss Tutt of Loudoun County, Virginia, described as of "rare charm and beauty," survived him with three children. They moved to Washington. John and Ann (Mrs. Robinson) afterwards lived in Louisville, Kentucky. 


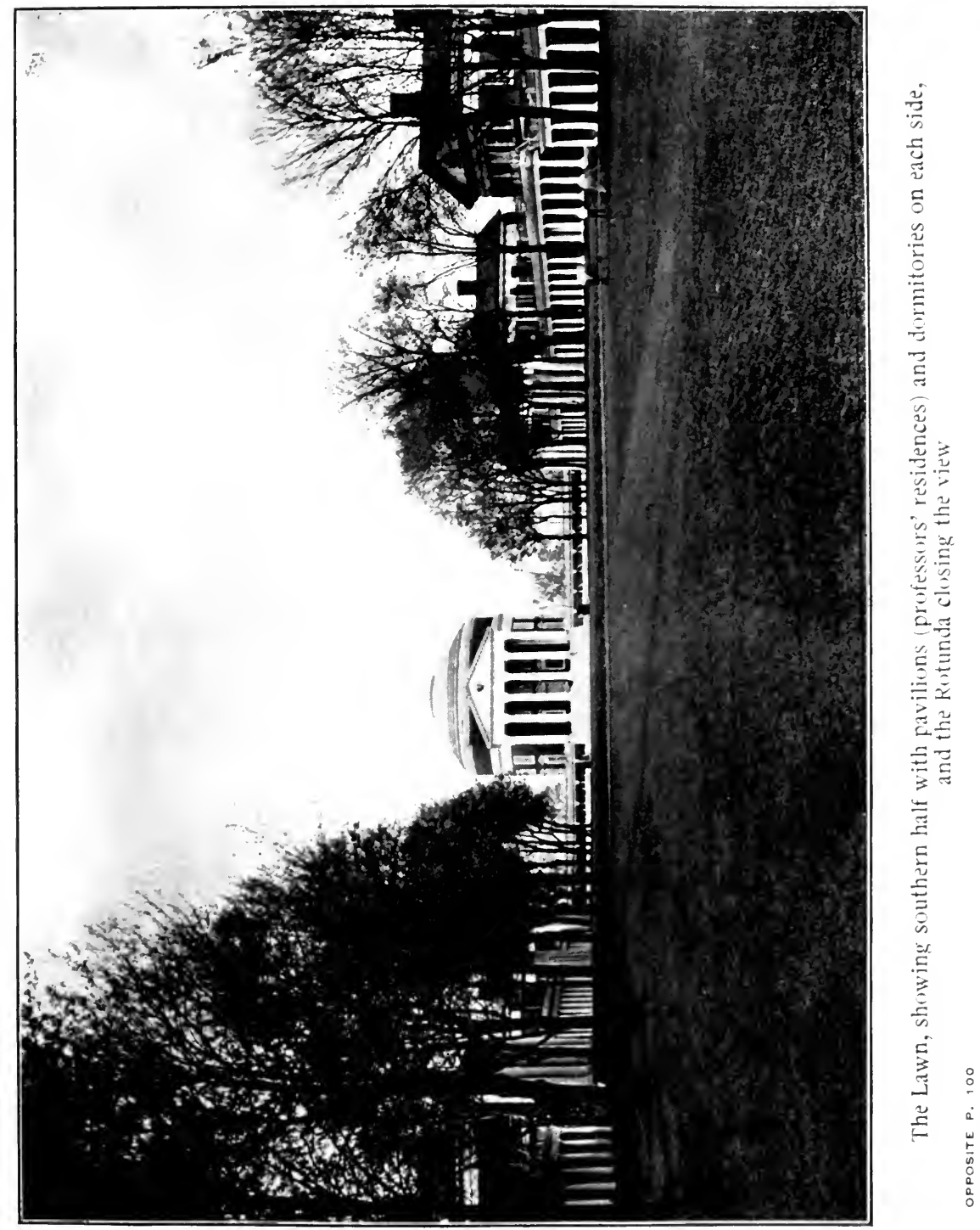



that the chief satisfaction to be derived from such a medical education would be in the resulting ability to estimate the extent and limits of the aid to human life and health reasonably to be expected from the art of healing. ${ }^{10}$ Nevertheless, Dr. Dunglison impressed him so favorably that he employed him as his physician, ${ }^{11}$ and submitted to his regimen without murmuring at "suffering inflicted upon him for remedial purposes."

Not counting Francis Gilmer, who never lectured, two others were members of the faculty of 1825George Tucker and John Patten Emmet. Mr. Tucker was the elder, being fifty, the only man past middle life in the body at that time. Twenty years later, at seventy, with more than fifteen years of life yet before him, he resigned because the retirement of his friend Henry St. George Tucker had left him no intimate companions in the University, where all his associates were much his junior. In the mean time, Dr. Gessner Harrison, Professor Long's successor, had married his daughter, and Professor Tucker left his home in Philadelphia every summer for a visit of several weeks at the University, where he was always welcome, especially with his grandchildren. Mr. Tucker, many years after his retirement from his chair, bore testimony to the agreeable social life in the early days of the University. Mr. Jefferson and Mr. Madison held him in high esteem, and respected him especially for his studies and in-

${ }^{10}$ See the report of the Rockfish Commission.

11 "Mr. Jefferson was considered to have but little faith in physic; and has often told me that he would rather trust to the unaided or rather uninterfered with, efforts of nature than to physicians in general. 'It is not,' he was wont to observe, 'to physic that I object so much as to physicians.' "Dr. Dunglison's Memoranda. 
forming essays on sociological subjects. These were widely read while he was in Congress, and it is probable his appointment was due to the reputation they won him. He wrote a life of Jefferson, an undertaking for which he was well qualified, a history of the United States, and many works which are a monument to his industry and a proof of the breadth and accuracy of his scholarship.

Dr. Emmet was probably bespoken as early as in those November and December days which Gilmer spent in New York recuperating from his voyage in the Crisis, for he was in that city on a visit from Charlestown, South Carolina, where he had established himself for the practice of medicine. At that time Professor Torrey endorsed him quite handsomely, and Mr. Gilmer proposed him, but it was not until March 4, 1825, that the appointment was formally made. Dr. Emmet was soon at his post, well impressed with his surroundings and especially pleased with Mr. Jefferson. His lectures were popular, and, like Mr. Bonnycastle's, attended by many not entered in his school. Taking extreme pains with all his lectures and experiments, he was severely taxed with work, but found consolation in his big violoncello Satan, which smothered "despair and fury amid its roar," and in working in his garden. Perhaps no other professor ever made so many experiments in horticulture and floriculture. At "Morea," the estate on the western confines of the University to which he removed in I8 34 or 1835 , he grew grapes from vines imported from Europe, and produced various wines and brandies. He cultivated the silkworm and carried the experiment to 
the extent of producing silk, and in many other ways indicated avenues to profitable industries. ${ }^{12}$

Dr. Emmet lived in the West Lawn pavilion nearest to the Rotunda, and as professor of natural history had domiciled in his bachelor mansion some strange "exhibits" in his subject. In r827 all this was changed. He had met at Professor 'Tucker's, at the opposite extremity of West Lawn, the professor's attractive niece, Miss Mary Byrd Farley Tucker of Bermuda, and in June of the same year their engagement was announced. The marriage soon followed and Dr. and Mrs. Emmet began housekeeping. Then the exhibits came up for consideration from the bride's point of view. One of the largest and best rooms was devoted chiefly to a collection of snakes, whose movements were somewhat retarded by a waxed floor. A brown bear, which had been raised from a cub, roamed at pleasure through the house and garden. A large white owl had full liberty of the house, and rested for a greater part of the time in his master's room on the top of a high four-post bedstead. The owl was soon allowed to shift for himself, and, in time, the bear became an addition to the larder, while the snakes were banished in as summary a manner as if St. Patrick had exercised his power to that end. ${ }^{13}$

These are the men who formed the active faculty of 1825 , and who lectured to the classes of the first session which extended from March 7 to December 15. The official records, such as they are, remain, but the period is gone, the conditions changed, and we who would realize it all must out of the few ele-

${ }^{12}$ Consult Professor Tucker's memorial presented to the Visitors, Faculty and Alumni, July 4, I845.

${ }^{13}$ Alumni Bulletin, I, 97. 
ments which time has not entirely destroyed reconstruct as far as possible the University as it was socially and otherwise in 1825 .

Fortunately some very pleasant glimpses of $\mathrm{Mr}$. Jefferson in his relations to the professors and the students remain, and they all tend to enhance admiration of a character so strong in its ennobling simplicity. "Mr. Jefferson is down with us almost every day," wrote Dr. Emmet, "and as often invites us to call without formality at his home. $\mathrm{He}$ is an extremely pleasant old gentleman, and as hospitable as man can be. We all take the greatest delight in promoting his views, and he has expressed himself as well pleased." The late Burwell Stark wrote in I894, still vividly remembering the great man: "While at the University I remember it was my good fortune and great pleasure to dine several times with ex-President Jefferson. It was his custom to invite to dinner about a dozen pupils at one time till all had visited him two or three times. His hospitality and sociability made us free in his company, and endeared him to all our hearts. As an instance of the high estimation in which the students held him, when they saw that he would pass on a certain side of our grounds they would often go out of their way in order to receive his recognition and most courteous bow:"

Dr. Henry Tutwiler was a fellow-student of Mr. Stark's. He and Gessner Harrison came from Rockingham County, Virginia, clad in homespun to win their way at the University, and they did win it, as all who are acquainted with the educational history of Virginia and Alabama know full well. 
Dr. Tutwiler's reminiscence ${ }^{14}$ describes a day at Monticello in the last years of its master, and it should be preserved and repeated on all suitable occasions as showing how kind and unaffected the great may be: "I well remember the first time I saw Mr. Jefferson. It was in I825, in the proctor's office, ${ }^{15}$ whither I had gone with some students on business. A tall, venerable gentleman, in plain but neat attire, entered the room, and, bowing to the students, took his seat quietly in one corner. One of my friends privately gave me to understand that it was Mr. Jefferson. I had come from a part of Virginia where he was very popular, and which he used to call his tenth legion, and his name was associated with my earliest recollections. I was struck by his plain appearance, and simple, unassuming manners. When Mr. Brockenbrough was done with the students, he looked up and recognized Mr. Jefferson, who then came forward to greet him. We used to see him afterwards as he passed our room on the Eastern Range in his almost daily visits to the University. He was now in his eighty-third year, and this ride of eight or ten miles on horseback over a rough mountain road showed the deep interest with which he watched over this child of his old age, and why he preferred the more endearing title of Father to that of Founder. This is also shown in the frequent intercourse which he kept up with the faculty and the students. Two or three times a week the former, often with their families, dined with him, by invitation, and once a week he had the students. He

${ }^{14}$ Address before the Alumni Society of the University, June 29, I882.

${ }^{15}$ The proctor's office was in the residence on Monroe Hill. 
had a list of these, and through one of his grandsons, then a student in the University, four or five were invited to dine with him on the Sunday following. This day was selected because it did not interfere with the regular lectures. When he found that some of the students declined the invitation from religious convictions, he ascertained how many there were of this class, and invited them on a week day.

"An account of one of these days by one who had the honor of enjoying this privilege may not be without interest. Mr. Jefferson had a wonderful tact in interesting his youthful visitors, and making even the most diffident feel at ease in his company. He knew from what county each student came, and being well acquainted with the most prominent men in every part of the State he would draw out the student by asking questions concerning them, or about something remarkable in his neighborhood, thus making one feel that he was giving instead of receiving information; or he would ask about the studies of the students, and make remarks about them or the professors, for all of whom he had a high admiration. He was thus careful to pay attention to each individual student. He sat with us at dinner where Mrs. Randolph presided, and related anecdotes of distinguished persons whom he knew abroad. I remember one particularly of Madame de Stael, whose acquaintance he formed in Paris, and whose talents and writings he greatly admired. At table the conversation turned on novels, and Mrs. Randolph spoke of her father's aversion to them. She said that when Ivanhoe came out she induced him to read it, with the hope and belief that it would change his opinion. Mr. Jefferson smiled and said, yes, he had tried to read it at her urgent request, but 
he had found it the dullest and hardest task of the kind he had ever undertaken. One of Mrs. Randolph's remarks excited no little surprise in her youthful guests: it was, that she had found Blackstone as interesting as a novel. After dinner he pointed out to us, among other paintings, one of Washington on horseback, and said that though not a handsome man he presented on horseback the most splendid figure he had ever seen. Such is a brief sketch of one day at Monticello, and every day was like it, only frequently on a more enlarged scale." 


\section{CHAPTER IX}

THE LAW PROFESSORSHIP

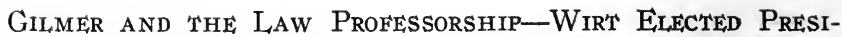
DENT AND PROFESSOR OF LAW-JEFFERSON'S DISSENTWir't Declines-John Tayloe Lomax The Firs' LECTURER IN THIS SCHOOL.

In the earlier months of the first session $\mathrm{Mr}$. Jefferson's optimism had little to check it. $\mathrm{He}$ was delighted with Gilmer's selection of professors who were profound in their scholarship and genteel in their behavior, marks of striking worth in the opinion of the Father of the University.

But he was not entirely free from concern. The school of law was still without a head. Gilmer was offered this chair for the second time not long before he sailed for Europe; indeed, the minutes of the Visitors show that he "was appointed to be professor of law or moral philosophy at his election, to be signified to the rector." There is no evidence that he ever considered the chair of moral philosophy at all, but he did weigh the possibility of final acceptance of the law professorship. After his return, and after his health had taken on a more hopeful appearance, he declined, preferring a more public career than the cloistered life of a pedagogue, and the chair was proposed indirectly to Henry St. George Tucker, and then directly to Judge Dade, Judge Philip P. Barbour, and Judge Carr, none of whom was available. In the fall, however, Gilmer's health 
was in such a feeble state ${ }^{1}$ that he feared he could not sustain the hardship attendant upon the practice of his profession in that day of great distances and bad roads, and he lent an attentive ear for the first time to Mr. Jefferson's solicitation. His acceptance was regarded as a fortunate conclusion of their trouble.

But Mr. Gilmer's health declined alarmingly as the winter advanced, and when the second session began he was too weak and debilitated to lecture. He died February 25, I826, at "Farmington," the estate of George Divers, his uncle by marriage, and was buried at Pen Park, the home of his ancestors. An occasional pilgrim, drawn to the old homestead by the fame of Wirt, who found his first wife there, and by the story of young Gilmer, finds his grave, with other tombs, in a small enclosure, which is not very well cared for, and reads the epitaph he made for himself: "Pray, stranger, allow one who never had peace while he lived, the sad immunities of the grave, silence and repose."

The death of the young professor restored the old problem of an incumbent for the chair of law. Mr. Jefferson became discouraged at the outlook. He seemed to fear the University would be reduced to accepting "a Richmond lawyer," or one of "that school of quondam federalism, now consolidation," and made ready to guard against the

1 There is some uncertainty as to Gilmer's motives. In August, 1825, Jefferson found him willing to accept (letter to Cabell August 4, 1825) because his health was "in a great degree reëstablished." while Wirt in his preface to the little volume of Gilmer's essays published in I828 assigns the opposite reason for his consent. 
dissemination of such principles by "a previous prescription of the texts.",

Cabell, in suggesting Tucker the year before, wrote to Jefferson: "It will be difficult to fill the law chair well, unless, perhaps, a judicial station were combined with it; and yet an interference should be as far as possible avoided. Suppose a small chancery district, consisting of the counties of Albemarle, Orange, Louisa, Fluvanna, and Nelson, were created, and the professor of law made chancellor of the district. The combination would be enticing to the first order of men." Whether $\mathrm{Mr}$. Jefferson thought the suggestion worth acting upon does not appear in the correspondence, but the next offer of the chair was accompanied by the tender of another dignity.

At Gilmer's death there seems to have been some expectation that his brother-in-law, William Wirt, would accept the chair, and the Visitors, at their meeting in April, r826, appointed him, and, to induce his acceptance, they created the office of president, and conferred it upon him. Mr. Jefferson dissented from his colleagues in regard to the creation of this office, and by consent of the Visitors, entered his protest on the minutes. The whole record, although written by Mr. Jefferson when he was within a few days of his eightyfourth birthday, is in clean, neat chirography, and covers less than two pages in the small minutebook:

"Resolved, That there be established the office of president of the University with a salary of fifteen hundred dollars per annum to be paid out of

${ }^{2}$ Jefferson to Cabell, February 3, I825. 
the annuity of the University, in the manner in which the salaries of the professors are paid.

"The President shall be the chief executive officer of the University, and as such charged with the general superintendence of the execution of all laws made for its government.

"The Proctor and all subordinate agents shall be subject to his control and direction in the execution of their respective duties.

"He shall convene the Faculty whenever he may think the interests of the institution require it, and whenever else any two professors shall request it.

"He shall preside at all meetings of the faculty, when present, and having a vote as professor, he shall have a casting vote as president, when the votes of the professors, pro and con, are equally divided.

"In his absence from the meetings of the Faculty a chairman pro tempore shall be appointed, in the absence of the President from the University, and in case of his disability by sickness, or otherwise, the Faculty may be convened and may act as at present.

"When the President shall believe that a student has committed any offense requiring trial before the Faculty, he shall have power to suspend such student, and in case of emergency, forbid him access within the precincts, till a board can be convened for his trial, provided that no such suspension or restraint shall be for a longer time than two weeks, if a board can be convened within that time. Any student violating the order of the 
President made pursuant to the authority hereby vested in him, shall be deemed guilty of contumacy, and punished accordingly.

"Resolved, That William Wirt, at present Attorney-General of the United States, be appointed President of the University and professor of law; and if he decline the appointment the resolution establishing the office of President be null and void.

"If the appointment hereby made shall be accepted, the professor will be expected to enter on the duties of his office as soon as his convenience will allow, not later, however, than the commencement of the next session.

"From the enactments establishing the office of President the Rector dissented. His dissent is ordered to be entered in the journal, and is in the words following:

"The subscriber, Rector of the University, fully and expressly concurring in the appointment of William Wirt to be professor of the school of law, dissents from and protests against so much of these enactments as go to the establishment of the office of President of the University for these reasons:

"First, because the law establishing the University, delineating the organization of the authorities by which it should be directed and governed, and placing at its head a board of Rector and Visitors has enumerated with great precision the special powers it meant to give to that board. in which enumeration is not to be found that of creating a President, making him a member of the faculty of professors, and with controlling powers over that faculty: and it is not conceivable 
that, while descending, in their enumeration, to give specifically the power of appointing officers of the minutest grade, they should have omitted to name him of the highest, who was to govern and preside over the whole. If this is not among the enumerated powers, it is believed it cannot be legitimately inferred by construction from the words giving a general authority to do all things expedient for promoting the purposes of the institution; for, so construed, it would render nugatory the whole enumeration and confer on the Board powers unrestrained within any limits.

"Second, because he is of opinion that every function ascribed to the President by this enactment, can be performed and is now as well performed by the Faculty as now established by law.

"Third, because we owe debts at this time of at least $\$$ II,000 beyond what can be paid by any means we have in possession, and may command within any definite period of time; and fixes on us permanently an additional expense of $\$ \mathrm{I}, 500$ a year.

"Fourth, because he thinks that so fundamental a change in the organization of the institution ought not to be made by a thin board, two of the seven constituting it being now absent.

"For these reasons the subscriber protests against both the expediency and validity of the establishment of this office. TH: JEFFERSON."

This early consideration of the presidency had for its motive the inducement of an eminent man to unite his fame with the fortunes of the institution. There was no pretense of any other purpose, for in case $\mathrm{Mr}$. Wirt declined the office was to cease. Mr. Wirt did decline, and the proposition to establish presidential government was not 
repeated until after the lapse of twenty years; and again after twenty years, when the same motive seems to have guided the Visitors. It would be interesting to know what modification of the structure and fibre of the University would have taken place if Wirt or Lee had become identified with its life.

Wirt advised Jefferson to appoint John Tayloe Lomax to the professorship of law, and Mr. Lomax became the first occupant of that chair. Wirt had met him as a brother lawyer in Richmond and elsewhere, and admired the courtly Virginian, who added to his graces the utility of a profound knowledge of the law. Lomax was nearly fortyfive years of age, and had won a secure reputation in the practice of his profession, which he had begun at Fredericksburg. Indeed, his good fame was the ultimate cause of his withdrawal from the faculty in I830, when he was made judge of the Fredericksburg circuit. While at the University he had his share of students who afterwards became famous, among them being $R$. M. T. Hunter, Alexander H. H. Stuart, and Robert Toombs. As a lecturer he paid much attention to style, and the learning he offered his classes lost nothing by his rhetorical method. The teaching of law seems to have been a vocation with him, for after he had gone on the bench he conducted a private law school to which many bright young men repaired. 


\section{CHAPTER X}

\section{EARLY EFFORTS AT GOVERNMENT}

Scheme of Government-Various OfFicers and Their DUTIE,S-JeFFERSON'S Thesis ON STUdENT GOVERNMENT -Some EXamples of His Rules or "Enactments"UNIFORM, AND EARLY RISING LAW-HARVARD PENALTIES-FIRST RIOT-APPEAL TO THE VISITORS-JEFFERSON's INDIRECT ANSWER to A STUdent PAPER.

The Visitors committed the administration of the affairs of the University to the faculty, organized with a chairman as the chief executive officer, aided by several subordinates directly responsible to him. These officers and employees were the proctor, patron, bursar, hotel-keeper and janitor.

The chairman was charged with the execution of all laws made for the government of the institution. He was to preside at meetings of the faculty, suspend students until that body could examine into the offenses charged against them, and, in a word, to assume the responsibilities now committed to college presidents; but the office was wanting in autocratic power except in one respect: the faculty could not punish or try an offense unless the case was "brought before them by the chairman."

The proctor was "master of police" and inspector of the lands and buildings, and this inspectorship extended to a weekly scrutiny of all the dormitories and a monthly visit to all the hotels, now called boarding-houses. His duty required a report to the chairman of the faculty of all injuries to University property, together with the name 
of the perpetrator, if known, and the collection of all fines imposed by the faculty. He also had charge of all building operations, made all contracts authorized by law, settled all accounts with contractors, and paid them by warrants on the bursar. In his capacity as master of police he was required to be diligent in observing all violations of law, to lay before the civil authority, when requested to do so by the chairman, such information as might prevent or punish breaches of the peace, trespass, etc. The patron and hotel-keep. ers were assistants to him in the matter of maintaining the police and good order.

When the student arrived at the University, and proposed to reside in the precincts, he found he was not permitted to matriculate till he had deposited with the patron all the money, checks, bills, drafts, and other available funds in his possession, and in any manner intended to defray his expenses while a student at the University. His deposit was required to be sufficient after deducting the patron's commission to discharge his indebtedness for his dormitory and the public rooms,- library and examination rooms, - to pay his professor's fees, three months' board to his hotel-keeper, and to purchase the text-books and stationery necessary to begin with, and ten dollars to cover contingent charges and assessments.

With his receipt from the bursar for this deposit he was finally permitted to present himself to the proctor for registration. That officer handed him a printed copy of the regulations, which he was required to master. These apprized him that all the funds received while a student he was required to deposit with the patron, and at the end of the 
first three months of the session he was expected to hand to that officer money to pay his board and other expenses for the ensuing three months. The final payment for the session was to be made at the conclusion of six months from the beginning. Having read over the enactments, eighteen pages of closely printed rules, the applicant was permitted to write his name in the matriculationbook.

A student not resident in a dormitory was expected to deposit in the same manner, except that he did not have an account with the bursar for board or books and stationery.

The expenses of a student were limited by University regulation: Clothing during the session not exceeding $\$ 100$; pocket money for the same period not exceeding forty dollars; for books and stationery whatever parent or guardian thought fit to allow; medicine and medical attendance, whatever was necessary. ${ }^{1}$

The money deposited with the bursar was paid out on the warrant of the proctor. Amounts for books and stationery were paid when an itemized bill was presented with the student's order to pay endorsed on it. Pocket money was treated discreetly: no draft was allowed to exceed, in any quarter session, a due proportion of the amount allotted for the entire session, and no order from one student in favor of another was honored unless for the purpose of some article the sale of which had been authorized in writing by the chairman. Plainly, debts of honor could not be paid by orders on the patron. The restraint of gambling

${ }^{1}$ The enactments named in this paragraph were not made the first session, but in December, 1826 . 
may have indeed been the object of this regulation. There were cases before the faculty in which as much as two hundred dollars had been lost in an evening. These dormitory games were often accented by fisticuffs, and in one case, certainly, by a cowhiding. On this last occasion the game was "all fours," and the fight was inspired by anger at loss and intensified by excitement arising from indulgence in mint sling. Perhaps the tipple was furnished by "an individual by the name of Ben-a black man," who sold spirituous liquors surreptitiously in the cellar of one of the dormitories until the proctor was directed by a resolution of the faculty to abate the nuisance. It was more probable that the sling was procured from some ordinary in the village. ${ }^{2}$

The hotel-keepers were appointed by the proctor, and were charged with some other duties than that of providing food for the students. The proctor could require them once a week to visit the rooms of the students in the morning and report to him all the violations of the law regarding early rising, and the faculty could exact from them testimony upon honor touching any matter of inquiry before that body. All opportunities of private gain were removed by an enactment forbidding the furnishing of entertainment for compensation to any one not a student or otherwise a member of the University community, and this inhibition extended to expelled students for the term

${ }^{2}$ One of the last entries in Mr. Jefferson's hand in the minutes of the Visitors is this: "Resolved, That the proctor be instructed to take proper measure against D. S. Mosby and Thomas Draffin for violation of the law concerning ordinaries and tippling houses, and to have their licenses revoked, if any they have." 
of five years. The hotel-keeper was not to permit any game of chance on his premises, "or any ardent spirits of wine, mixed or unmixed, to be drunk within his tenement."

One of the duties of the janitors was to visit the dormitories in the morning and report violations of the law requiring students to rise early. This was sufficient to make him a man of many sorrows, but he had other burdens, such as attending meetings of the faculty, their several schools while in session, and the meetings of the Board of Visitors, waiting upon the professors of natural philosophy and chemistry in their lecture-rooms and in the laboratories, winding up and attending to the clock, etc.

It must be understood that by far the greater part of these regulations-such as limiting the pocket money, the deposit of all funds with the bursar, etc.-were enacted after Mr. Jefferson's death, and during the rectorship of James Madison. The year 1828 was prolific of enactments,many of them yet to be referred to,-some of which the first rector would probably have disapproved. Jefferson's greatest gifts to the world proceeded from his idealism, which was always sane, and invariably convertible to practical use and service. This sanity was the natural profit of a mind which insisted upon truth and never trafficked with ingenious and sophistic premises.

One of the finest gifts of his idealism-in our day converted to a practical realism, and yielding superlative benefits - was his thesis in the report of the Rockfish Commission on the best mode of governing the young in large collections, "certainly a desideratum not yet attained by us." "It 
may be well questioned," he continues, "whether fear, after a certain age, is a motive to which we should have ordinary recourse. The human character is susceptible of other incitements to correct conduct more worthy of employ and of better effect. Pride of character, laudable ambition, and moral dispositions, are innate correctives of the indiscretions of that lively age; and when strengthened by habitual appeal and exercise have a happier effect on future character than the degrading motive of fear. Hardening them to disgrace, corporal punishments and servile humiliations cannot be the process for producing erect character."

The chapter on discipline and police contains eight printed pages, the most of them filled with prohibitions, inhibitions and penalties, which, combined, left room for only a very narrow way for the student's feet. Inattendance, inattention, indecorum, or misbehavior were prohibited by law. No student was permitted to appear in the lecture-room with a stick or weapon, to remain covered without professorial consent, to use tobacco by snuffing, chewing, or smoking. Servants, horses, and dogs within the precincts were forbidden to students. Noises in dormitories or in the precincts, the possession of weapons, and the discharge of fire-arms, were all offenses, "but the proper use of musical instruments" was "freely allowed, except during lecture-hours, and after Io at night, as well as on Sundays." Mr. Jefferson was himself a violinist. The professors were in part charged with the execution of the regulations, and when one of them knocked at a student's door the latter was required to open or the professor could have the door broken in, and 
the cost of repair charged to the inmate. Any professor, the proctor, the hotel-keepers, and the janitors, in one way or another, all had official right of entry into the student's room. Among the many prohibitions were habits of expense, dissoluteness, dissipation, profane swearing, wearing of masks, and playing at games of chance, as these habits "were obstructive to the acquisition of science."

If the student would "make any festive entertainment within the precints of the University" he had to get the consent of the chairman, and the regulations advised that officer that "as such entertainments are for the most part unfriendly to collegiate duties they should be allowed with caution." Public dinners were strictly prohibited, but on the occasions of the celebration of the anniversary of independence and Washington's birthday a ball or other evening party attended by professors and students, "having its pleasures chastened by the company of ladies," was allowed under conditions. This limitation of celebrations was not consonant with the feelings of the students. The 8th of January, the I 3 th of April, and the rgth of October claimed recognition, and were soon duly observed. The chairman very wisely granted permission, and several balls during each session were fixed social fetes. These took place at Fitch's Hotel in Charlottesville, or at Midway Hotel, or at one of the University hotels, always kept by persons of good family. The writer of reminiscences of those days would scarcely fail to record the highest praise of the dance music furnished by the Scotts. There were four of these musicians-father and three sons; 
and they played the real old Virginia jigs, reels, breakdowns, and the like, "with fervor, with spirit, and proper accentuation." In I829, when William C. Rives went as minister to France, he took with him one of the Scotts to be his body-guard. Scott heard Paganini in the French capital, and, it is said, foreswore the violin forever.

The consent of the chairman or some professor was necessary to a student's absence from the precincts at night, "unless on a visit to a respectable family," and the same permission was necessary to his visit "to any tavern or confectionery," and it is needless to say that a student who asked for such a privilege had to enforce his request with the best reasons before it was granted. Written or extempore addresses, or orations, in public were lawful only when permitted by the faculty.

Mr. Jefferson seems to have expected that the duelling customs of the German universities would be introduced at his institution, where they would have been a more serious matter than a brawling pastime, and with his own hand he drew an enactment which has probably never been violated ${ }^{3}$ to the extent of a duel actually fought. It provided that every student who engaged in a duel or combat with weapons which might inflict death either by fighting or being in any manner accessory should be liable to instant expulsion, and the sentence was not remissible by the faculty, and did not need the approval of the Board of Visitors. The proctor was required to give in-

${ }^{3}$ There have been sham duels, such as the one in the fall of 1877 between William Mahone and Bradley Johnston, which hoaxed the college community for a day, and a challenge to fight with deadly weapons has occurred once in the memory of the writer. 
formation to the authorities with a view to aiding the civil punishment of the offenders. There have been several challenges to combat, but rarely with weapons that might inflict death. The encounters have all been fistic, and there was severe punishment in some cases, but never death.

The following enactment caused "discomfort" and gave rise to much trouble and some humorous episodes: "The bell shall be rung every morning throughout the session at dawn. The students shall rise at this signal and dress themselves without delay. Their rooms shall be cleaned and set in order, and they prepared for business at sunrise; at which time the proctor shall, at least once a week, inspect their apartments and see that they are in proper order. The bell shall be again rung at Io o'clock at night, by which time at least the students shall retire to rest, and after which time perfect quiet shall be maintained within the precincts, and no light shall be kept burning in any dormitory unless in case of sickness or by the special leave of the chairman. It shall be the duty of the proctor to see that the lights are extinguished accordingly. He shall scrupulously report all breaches of this enactment to the chairman, and any student who shall violate it shall be subject to any of the minor or major punishments."

This ordinance was passed by the board July 24, 1828. James Madison, rector, James Breckinridge, Chapman Johnson, John H. Cocke, William C. Rives, and Joseph C. Cabell were present, but the minutes give no hint as to who proposed or who voted for the measure.

The clause requiring the ringing of a ro o'clock bell and the retirement of the students to bed at 
that early hour was rescinded at the next meeting, which took place in October, I828. The remainder of the law was on the statute books as late as I870, but it had been a dead letter a long time. A bell is still rung at a very early hour in the morning, but this may be the janitor's compliance with a practice no longer enjoined, long after all knowledge of the originating mandate has been lost to his kind.

In the old, strenuous days, when the big bell in the Rotunda was rung at dawn, when the janitor knocked at the door of each dormitory and looked in at that early hour to see that the summons to the business of the day was obeyed, that personage was often the object of the malevolent humor of the disturbed student; bucketfuls of water descended upon him from the door-tops, where they had been balanced with diabolical skill, or other unwelcome attentions were bestowed upon him. He had his means of revenge, however, and pursued it with a steady purpose. He would submit a full report of any mistreatment to the faculty, and the offending student would be suspended and rusticated for a fortnight or so, which time he usually spent very agreeably at some tavern-perhaps Cocke's or Bowcock's-a dozen miles from Charlottesville. Sometimes the student deceived the janitor by jumping out of bed as he approached, donning a dressing gown hastily, and taking a seat with a text-book in readiness. When Spinner, or Brockman, or "Dr." Smith, whoever the janitor happened to be, looked in he found an apparently exemplary student busy at his task; if he had looked a moment later he would have found the studious young man in bed again. But 
the enactments caught the student in the end, for one of them required the hotel-keepers to furnish a list of such of their boarders as were absent from breakfast and of those who appeared a half-hour after the breakfast bell had been rung. ${ }^{4}$

The faculty was authorized to prescribe the details of the fare at the hotels, "if they found it convenient." 5 The enactments positively prohibited luxury, but required plentiful, plain, good, wholesome viands, neatly served and well dressed. Compensation for "diet, bedding and furniture for their dormitories, and washing, also proper attendance of servants for domestic and menial duties," was $\$ 100$ for the session, paid monthly. And with all this went an inquisitorial inspection by the faculty through the proctor or the proctor's agent, which descended to a scrutiny of the student's laundry or to an inquiry as to whether the bread was burnt or the steak tough. Many years after these enactments were promulgated a proctor flatly refused to perform this duty, and the fact of the refusal was entered upon the minutes of the faculty, and perhaps reported to the Board of Visitors.

Among the post-Jeffersonian enactments was a series of regulations on student dress which were for years a cause of bitter feeling on the part of some of the collegians and a source of trouble in and out of the faculty. These rules prescribed that the attire of students should be uniform and plain: the coat, waistcoat and pantaloons of cloth of a dark gray mixture, known as Oxford gray

"Eventually the early rising rule was changed to require students to rise in time for breakfast.

They found it convenient and at last two regulation bills of fare are given in the faculty minutes. 
broadcloth, at a price not exceeding six dollars per yard. The coat was required to be singlebreasted, with a standing cape, and swallow-tailed, the skirts of a moderate length, with pocket-flaps; the waistcoat single-breasted, with a standing collar, and the "pantaloons of the usual form." The buttons of each garment were flat, and covered with the same cloth. The pantaloons and waistcoat of this dress could be varied with the season without offense. For instance, the waistcoat might be white and the pantaloons of light brown cotton or linen. Boots were absolutely prohibited; plain black neck-cloths were prescribed for winter and white for summer, while no difference seems to have been made in the hat, which was required to be "round and black." A surtout of cloth of the price and color of the regulation dress was allowed, but not as a substitute on occasions of public examinations and exhibitions within the University.

The proctor, under the direction of the executive committee, provided the model according to which each article of the dress was made, and the regulation enjoined conspicuous badges on the coat-an embroidered black silk star on each side of the collar-and permitted the addition of the customary badges in case of mourning. This uniform was strictly enforced for years, except that in warm weather the student was permitted to wear within the precincts a light gown or coat of a pattern approved by the chairman.

The uniform law was passed by the Visitors December 16, I826: present, Madison, Monroe, Cocke, Cabell and Johnson, ${ }^{6}$ and repealed in 1845 .

' On the previous day four members of the board, which was not a quorum, assembled, and the following entry was 
This final action the Visitors approached with apparent reluctance. In 1842 they suspended the law "for one year from date" (July 5). The suspension was renewed in 1843 and I844; and a resolution rescinding it was passed July 4, I845.

The law had been in force a year before the clauses requiring gaiters in winter and ordaining the color of the stockings were repealed. In spite of the effort of the Visitors to require plain attire, there were many instances, before the law was suspended, of extravagance in dress. The fop was abroad then as now, the difference being less in the man than in the colors that appealed to his vanity. With less restraint, perhaps, the exquisite of I840 donned a garb of straw-colored pantaloons, striped pink and blue silk vest, with a white or straw colored ground, crimson merino cravat with yellow spots on it, coat of fine cloth, and cloth cap trimmed with rich fur.

The year 1824-the one in which nearly all the regulations passed in $\mathrm{Mr}$. Jefferson's lifetime were framed - the following section fixing punishments was adopted by the board:

"Punishments for major offenses shall be expulsion, temporary suspension, or interdiction of residence or appearance within the precincts of the University. The minor punishments shall be

made in the minutes: "A note was received from Mr. Johnson stating that some drafts of enactments which he had been charged with preparing were not completed, and asking leave of absence until tomorrow. This leave was granted." Among the enactments of the following day-nearly twenty octavo pages of them-were those on the uniform, limiting pocket money, etc. This raises the presumption, but does not prove, that Mr. Johnson was the author of these regulations.

'Cf. Johnson's Life and Letters of Robert Lewis Dabney, p. 54 . 
restraint within those precincts, within their own chamber, or in diet; reproof of the professor privately, or in presence of the school [class] of the offender, or of all the schools, a seat of degradation in the school-room of longer or shorter duration, removal to a lower class, dismission from the school-room for the day, imposition of a task."

Much of this is amazing and almost incredible in this day. The most of these penalties would now be, and probably were then, impossible of application to even children of spirit. What a distance lies between this conception of young manhood and that to which Mr. Jefferson pays the tribute of a noble enactment made at the same meeting: "When testimony is required from a student it shall be voluntary, and not on oath, and the obligation to give it shall be left to his own sense of honor." These enactments have a strange sound when read in connection with the lofty sentiment of the Rockfish Commission that "hardening them [youth] to disgrace, to corporal punishments and servile humiliations, cannot be the best process for producing erect character."

The folly of these futile fulminations against youthful indiscretions is rendered more obvious by the permission to form a student board of censors: "Minor cases may be referred to a board of six censors to be named by the faculty from among the most discreet of the students, whose duty it shall be, sitting as a board, to inquire into the facts, propose the minor punishment which they think proportioned to the offense, and to make a report thereof to the professors for their approbation or their commutation of the penalty, if it be beyond the grade of the offense."

${ }^{8}$ MS. Minute Book, I, p. 67. 
The object of this legislation was to put into effect Jefferson's theory of self-government, but it seems remarkable that he should have believed a body of students for which a code of such puerile penalties was regarded as necessary could wisely and safely have so large a share in the government of this institution. One would think that the imposition by a student court of a sentence to an hour on "a seat of degradation" would produce conditions not promotive of academic calm.

But these Virginia statesmen were not the only men who framed drastic codes for universities. Harvard, influenced by the great English schools, embedded in her academic code provisions for corporal punishment inflicted publicly and with details that were humiliating to the last degree, ${ }^{9}$ and continued them in force for nearly a century after England had abolished them. There were enactments against "profane cursing and swearing," the "frequenting of alehouses," "extravagant expenses at taverns" for drink, running accounts for liquors until they amounted to "a very enormous sum," "breaches of the Sabbath," "costly habits," "wearing gold or silver lace, silk night gowns," etc., absence from dormitories at "unseasonable times at night," and many other offenses also described in the early enactments of the University of Virginia. It is altogether likely that Ticknor ex-

- An instance is given in Peirces History of Harvard University, pp. 227-8. Thomas Sergeant was "convicted of speaking blasphemous words concerning the H. G.," and condemned to be "publickly whipped before all the scholars," as well as to other penalties. Prayer preceded and followed the function. The president, tutors and professors were authorized, as late as I734, to "punish undergraduates by boxing," but "corporal punishment was going out of use" in 1746. 
plained the Harvard code to Jefferson when he visited Monticello in $18 \mathrm{I} 5$, and certain that the latter made a study of the enactments of the New England university to guide him in his preparation of a code. The two bodies of college law were alike in an important and significant respect - the major punishments of both were inoperative until approved by the Board of Overseers in one case and the Board of Visitors in the other.

In September, I825, the faculty requested the Visitors to repeal the most puerile punishmentssuch as "restraint within the precincts, within their own chamber, or in diet, a seat of degradation in his school-room of longer or shorter duration, removal to a lower class, the imposition of a task." The faculty minute-books furnish no evidence that any of these penalties were ever imposed. The Visitors "expunged" them from the enactments.

Any one privileged to read the minutes of the first session of the University-comprised in about thirty pages of the manuscript minute book -would necessarily come to the conclusion that more than "a lurking few" of the first students who enrolled in Mr. Jefferson's university were "unworthy." Nearly every page recites offenses which are never committed now, and which seem to mark the offenders as wanting in self-respect and ordinary common sense. On the other hand, with many evidences of good judgment on the part of the professors were mingled instances of bad in the cognizance of breaches of order which. would have been better overlooked. Unfortunately the Visitors seemed to enjoin espionage. ${ }^{10}$

${ }^{10}$ Minutes, I, 89. 
But it would not be just to ascribe all the disorders that disturbed the academic peace at either institution to unwise laws. Certainly foolish legislation produced some offenses, but in all large collections of young men, as the venerable rector of the University pointed out, there is sure to be an "unworthy few" ready to engage in irregularities more or less vicious. These "lurking" youngsters soon made themselves felt to the grief of Mr. Jefferson, who found his pet scheme of self-government jeopardized, to say the least.

The Lawn became the scene of nightly disorders promoted by armed and masked students. Insults were offered to the foreign professors, and everybody else. The professors took measures to suppress these riotous demonstrations. They tore the masks from the faces of rowdy collegians, who countered with profane language, sticks and brickbats. On the evening of Saturday, October I, I825, the outrages culminated. The faculty was convened on Sunday morning, and it resolved that "an address be drawn up to the students expressive of the abhorrence of the faculty at the outrages, and requesting them to aid the faculty in the discovery of the perpetrators"-a false step of which the students promptly took advantage. It was also resolved that a letter be addressed to the Visitors stating the unanimous determination of the faculty to resign unless an efficient police were immediately established in the University.

On Monday the professors convened to receive the response of the students to the address. What the answer was may be gathered from this entry in the minutes: "A paper was handed in signed by sixty-five students expressive of their deter- 
mination not to act the part of informers and of their indignation at the aspersion thrown upon them by the faculty in expressing a belief that they were capable of such baseness. They denied the fact of any assault having been made upon any professor, and asserted that on the contrary two professors had attacked one student ${ }^{11}$ and that he was justified in making resistance."

Ex-President Madison, General Breckinridge, General Cocke, Mr. Cabell, Mr. Johnson, and Mr. Loyall had arrived at Monticello, probably on Saturday, and had remained over Sunday, to confer in regard to matters to be disposed of at the meeting of the Visitors on Monday. The faculty, in its perplexity, referred the matter to the board, and the venerable men composing that body repaired to the University and held a meeting in one of the lecture-rooms of the Rotunda, at which occurred one of the most notable scenes in the history of the University. The students were summoned to meet them. "At a long table in the center of the room sat the Board of Visitorsmost of them men venerable for their age and distinguished for their great services to the country - Thomas Jefferson, James Madison, Chapman Johnson, Joseph Cabell, John Cocke, and one or two others, ${ }^{12}$ with their secretary, Nicholas P. Trist. Mr. Jefferson arose. He began by saying that this was the most painful event of his life, but

\footnotetext{
11 The student alleged to have been assaulted by two professors admitted that he had not been so attacked, but said that at different times Professor Tucker and Professor Emmet had laid hold of him. The latter had torn his shirt sleeve as well as a counterpane which he had about him. This student was one of those who signed the paper which charged "two professors with attacking one student."

12 The others were James Breckinridge and George Loyall.
} 
soon became so much affected that he could not proceed. He then turned to Mr. Johnson, and said that he must commit to younger hands the task of saying that which he felt himself unable to say. Those who have seen and heard this eminent lawyer will remember his dignified bearing, his bright and intelligent face, his earnest and persuasive manner. If eloquence is to be estimated by its effects, I have never heard any that surpassed this. His glowing appeals to their honor, the withering scorn with which he denounced the outrages, were irresistible. When the guilty students were asked to come forward and give their names, without any apparent concert there was a simultaneous rush to the table. While Mr. Trist was taking down the names, one of those concerned in the riot arose and disclaimed on the part of himself and his associates the acts of outrage which had been perpetrated by only a few, and said that no one felt more scorn for the guilty authors." "13

The secretary of the board furnished the names to the faculty, and an examination was held at once. Four students were expelled, and some others were visited with minor punishments.

Mr. Jefferson's noble belief in the sufficiency of young manhood for its own government was assailed by the conduct of these young hotspurs, for certainly they were not yet ready for the liberty with which the venerable rector would have invested them. But he did not make the mistake of attributing the character of the foolish and vicious few to the whole body of students. On

${ }^{13}$ Address of Henry Tutwiler, LL. D., of Alabama, before the Alumni Society, June 29, I882. Dr. Tutwiler witnessed the scene he describes. 
the contrary, he addressed to the rational and manly among them a dignified appeal for a right sense of honor and a proper co-operation with the faculty-an appeal which was an ovewhelming answer to "the paper" which sixty-five of the students had communicated to the faculty. This address is in the form of a resolution addressed to the professors, in which they are requested to make known to the students "that it is with regret that some breaches of order committed by the unworthy few who lurk among them unknown render necessary the extension to all of processes afflicting the feelings of those who are conscious of their own correctness, and who are above all participation in these vicious irregularities. While the offenders continue unknown the tarnish of their faults spreads over the worthy also, and confounds all in common censure, but that it is in their power to relieve themselves from the imputations and painful proceedings to which they are thereby subjected by lending their aid to the faculty on all occasions towards detecting the real guilty. The Visitors are aware that a prejudice prevails too extensively among the young that it is dishonorable to bear witness one against another. While this prevails, and under the form of a matter of conscience, they have been unwilling to authorize constraint, and have therefore, in their regulations on this subject, indulged the error, however unfounded in reason or morality. But this loose principle in the ethics of schoolboy combinations is unworthy of mature and regulated minds; and is accordingly condemned by the laws of their country, which in offenses, within their cognizance, compel those who have knowledge of a fact, to declare it for the purposes of 
justice and the general good and safety of society. And certainly where wrong has been done, he who knows and conceals the doer of it, makes himself an accomplice, and justly censurable as such. It becomes then but an act of justice to themselves that the innocent and the worthy should throw off with disdain all communion of character with such offenders, should determine no longer to screen the irregular and the vicious under the respect of their cloak, and to notify them, even by a solemn association for the purpose, that they will cooperate with the faculty in the future for the preservation of order, the vindication of their own character, and the reputation and usefulness of an institution which their country has so liberally established for their improvement, and to place within their reach those acquirements in knowledge on which their future happiness and fortunes depend. Let the good and the virtuous of the alumni of the University do this, and the disorderly will then be singled out for observation and deterred by punishment, or disabled by expulsion, from infecting with their inconsideration the institution itself, and the sound mass of those which it is preparing for virtue and usefulness." 


\section{CHAPTER XI}

\section{"THE COURT OF THE UNIVERSITY"}

Court of Record For Trial of Students-Professor of LAw to be Judge, With Powers of a Justice, of the PeaceGrand JuRy, With SOME StUdent Members-Proctor to Sergeant with Power to Command a Posse Comitatis.

Naturally the riotous conduct of the students on the evening of the first of October, I825, made discipline an important subject of consideration by the Visitors at their session which continued through the next week. The following minute appears in the records of the sitting of Thursday:

"Resolved, That Mr. Johnson, Mr. Cabell and Mr. Loyall be appointed a committee whose duty it shall be to consider and enquire what system may be digested for the better government of the University; that they be especially charged with the duty of considering how far it may be practicable and prudent to connect with the University a court having cognizance over misdemeanors committed within the precincts of the University, and over those committed by members of the.University, within the County of Albemarle; and that they report thereupon to the next meeting of the Visitors."

In this resolution the venerable rector seems to be recurring to a system of government which he had, in another form, proposed in the bill authorizing the establishment of the Central College. One section of that bill conferred upon the proctor the powers of a civil magistrate, and to that 
the legislature refused to consent. ${ }^{1} \mathrm{Mr}$. Jefferson defended the proposition at that time, and the above resolution is practically a renewal of it.

The board fixed upon the second Monday in December as the time for receiving the report of the committee, but no meeting was held until April, and it was not until October, 1826-some months after the death of the Father of the University-that the minutes show any evidence that a report was ever presented. Then under date of the 6th appears the following elaboration:

"As soon as the sanction of the legislature can be obtained there slatl be established in the University, a Court of Record, to be called 'The Court of the University,' and to be organized as followeth:

"The professor of law shall be $c x$ officio, sole Judge of the Court, and shall receive, as compensation for his judicial services, a salary not exceeding five hundred dollars, to be regulated by the Visitors and paid in like manner with his salary as professor of law.

"This court shall have concurrent jurisdiction with the county court of Albemarle, over all offenses against the laws of the land, except felonies, committed by any, within the precincts of the University: and over all such offences, committed by students, within the county of Albemarle. It shall moreover have jurisdiction over all such offenses committed by students against the laws of the University as shall from time to time be made cognizable thereon, by the Visitors.

"Proceedings in this court for the punishment of offences against the laws of the land, shall be,

${ }^{1}$ See page 28. 
in all respects, according to the course of the common law courts in this Commonwealth, - and proceedings for the punishment of offences against the laws of the University shall be according to the course prescribed by those laws.

"The judge of the court shall be a conservator of the peace, within the county of Albemarle; and, within that limit, shall have the same power as a justice of the peace for the county to arrest any one charged with an offence, to issue warrants for that purpose, to take recognisances of the peace, recognisances of good behaviour, and recognisances for appearance, either in his own court, or any other court where the offence may be cognisable.

"The terms of the court shall be monthly and quarterly, to be held on the — Monday of each month, except April, August and September, and continue from day to day, and from time to time, as long as the business shall require.

"The quarterly terms shall be in November, March, May and July; _- and shall have jurisdiction of all causes cognisable in the court.

"The monthly terms shall be in October, December, January, February, and June; and shall have concurrent jurisdiction with the quarterly terms of such causes only as are not tried by jury.

"At every quarterly term a grand jury from the body of Albemarle County shall be summoned and impannelled, and solemnly charged on oath to present all offenses cognisable in the court. Every person qualified as a grand juror for the county court of Albemarle, and, moreover, all students of the University above the age of nineteen years, and all hotel-keepers of the University, shall be 
competent grand jurors in the court of the University, and a due proportion of such students, under the direction of the judge, shall be impannelled on every grand jury.

"Petit jurors for the court of the University shall be qualified in like manner as petit jurors for the county court of Albemarle, except that no student shall be of the petit jury.

"The proctor of the University shall be the sergeant of the court, and he, with such deputies as the judge may approve, shall summon all its juries, execute all its processes, original, mesne, and final; and perform all the duties in relation to the court and to the judge thereof in vacation that are performed by the sheriff of the county, in relation to the county court, and the justices thereof in vacation.

"The sergeant and his deputies shall be conservators of the peace within the county of Albemarle, and may command a posse comitatis in like manner as the sheriff to enable them to execute their lawful authority. He shall have the same fees of office as are allowed a sheriff for similar services.

"The court shall have the same power to issue process beyond its jurisdiction, and the same power to compel obedience to its lawful process and lawful orders, with that possessed by a county court in similar cases.

"Until some other place of confinement be provided by law the jail of Albemarle county shall be used as the jail of the court of the University, and the keeper thereof shall receive and retain in safe custody all persons lawfully committed thereto by the said court or its officers, or by the judge there- 
of in vacation, in the same manner as if they had been committed by the authority of the county court of Albemarle.

"The court shall appoint its own clerk, who shall hold his office during the pleasure of the court, shall give bond and security for the performance of its duties in such penalty as the Visitors shall prescribe, shall receive fees of office such as are allowed the clerk of the county court for similar services, and receive such farther compensation for the performance of his duties as shall be allowed him by the Visitors from the funds of the University.

"All counsel and attorneys licensed to practice in the courts of this Commonwealth may practice in the court of the University on taking the proper oaths of office, and the court shall appoint from among them one who shall prosecute all pleas of the Commonwealth in that court, and shall receive the same fees and compensation for his services as are allowed to an attorney for the Commonwealth in the superior court of law, to be paid in the same manner."

The legislature again withheld its consent. Probably that body reasoned that courts were already provided to deal with law-breakers, and that students accused of misdemeanors, the grade of offense over which the proposed University court was given jurisdiction, could and should be subjected to the usual process and punished by the penalties provided for other culprits. Mr. Jefferson had desired a University tribunal out of tenderness for the youth whose indiscretions would put them in the clutches of a magistrate, while the law-makers in Richmond probably concerned 
themselves with seeing that no favored class of offenders was produced.

Again in 1832 the proposition was brought forward. At their annual meeting the Visitors constituted themselves "a committee of the whole to take into consideration the propriety of applying to the legislature for the establishment of a court of record in the University." Government of students was yet an unattained desideratum, and the Visitors seemed to have believed still that order must come out of a system of legal restraints and punishments-a belief probably strengthened by the fact that the best men among the professors for the office of chairman had met with failure. The untried ones, at that time, were Bonnycastle, Blaettermann, Harrison, Davis and Emmet. Emmet's work and health combined to put him aside, even if otherwise available. Blaettermann seems never to have been regarded as suitable. Harrison was young. Bonnycastle stern and unconciliating, and Davis but a recent addition to the faculty. Tucker was chairman then and probably regarded as by far the best man for the place. In this baffling condition of things the Visitors decided by the resolution already produced to turn again to the legislature. Nothing came of it, and the University drifted into disorders that moved to a tragic climax.

When the tumults of April, I845, compelled the Visitors to meet in haste, the question of discipline was once more a principal subject of discussion, and again there seemed to be no way out of the trouble except through a University court. The board passed this resolution, "That, with a view to improve the government and discipline of 
the University, Professor Henry St. George Tucker be requested to prepare and lay before the Visitors at their annual meeting or the 4 th of July next his views of the best plan and organization of a special court of record to be established at or near the University with authority to take cognisance of offences affecting the peace, order and general prosperity of the institution."

No doubt Judge Tucker complied with the request but there is nothing in the minutes of the Visitors or in those of the faculty to show what was really done with the problem. Perhaps it was solved when the Court of Justices sat at the University, as it did on the very day the resolution reproduced above was written, and Sheriff Ben Ficklin placed armed men in charge of the precincts. This indicated that the existing courts were then available, even to the extent of holding their sessions within the college precincts. 


\section{CHAPTER XII}

\section{THE WILD DAYS OF OLD}

REBELLION OF 1833-MEeting IN Hotel C-Faculty MEETINGS-STUDENT DEIEGATION AND ITS MisSION OF DEFIance-Chaplain Hammetr's Good Offices-The MatTER ENDS LAMMELY-REBELLION OF 1836-DEFIANT STUDENT Military-ARMEd Citizens-SeVEnTy Students EXPELLED-CHAIRMAN DAVIS'S DEFENSE OF THE ACT.

The students twice engaged in serious rebellion against authority. The first one, by some mistake about the date, is generally called the "Rebellion of I834," although it took place in I833.

The Visitors, at the suggestion of Chairman Bonnycastle, it is believed, passed in September, I833, an order providing that whenever a riot or other serious violation of good order and decorum occurred among the students within the precincts of the University after night, the chairman could, in his discretion, cause a signal to be given by bell or otherwise for each student to retire to his room and stay there during the remainder of the night unless sooner released. The chairman did not promulgate this order until November 7. Notices were posted that day for a meeting at Hotel $\mathrm{C},{ }^{1}$ the usual place for student mass-meetings. The first placards stated that the object of the convocation was to enter into a compact "to resist the late tyrannical movements of the faculty." When Chairman Bonnycastle read this statement on many of the dead walls of the University he thought it meant renewed ef-

${ }^{1}$ The present Jefferson Society hall. 
forts against the uniform law. But in the afternoon there was another call. This time it was an invitation to "an orderly meeting" to take into consideration the propriety of resisting the law passed by the Visitors at their late meeting requiring students to retire to their rooms in case of riot or other serious disturbance at night. The faculty met at half past four o'clock, but adjourned to see what the students would do.

Professor Bonnycastle closed Hotel C to the students, but they broke in and held their meeting. There were sixty or seventy present, and the proctor succeeded in taking the names of forty-four. Three of them were summoned before the faculty on the charge of breaking the door, and their dismission was expected. No record of the proceedings of the meeting is extant except the announcement that its object "would be considered as having failed if they did not succeed in getting the signatures of a hundred and fifty students." Probably the matter would have ended without disorder but for the belief, perhaps well founded, that the three students accused of breaking the door open would be dismissed.

On the afternoon of the 8th another meeting was held in Hotel $\mathrm{C}$, and much time was devoted to considering the proper course to pursue in regard to the accused students. Resolutions were passed and a committee appointed to present them to the faculty, which met at 4.30 that day "in the library room," and to make further and explicit representations to that body.

Thomas L. Preston, afterwards a rector of the University, was at the head of the committee, and was its spokesman. He informed the faculty ex- 
plicitly that the students charged with breaking open the door of Hotel $\mathrm{C}$ had no part in that act. This information was given, he said, with the distinct understanding that it was not a concession. The committee was instructed to answer no further questions in regard to the meeting, and it was resolved that "we are determined to abide by what we have done, let the consequences be what they may."

In regard to the original subject the committee said the meeting held that the students were bound to obey the public laws only, and considered the enactment of the Visitors just announced an ex post facto law. They made known the belief of the students that they had a right to meet in Hotel $\mathrm{C}$ whenever they deemed it proper to do so, and did not approve the application, made that day, to the chairman for permission. Every member considered himself bound to abide by any punishment the faculty might inflict upon any one on account of the meeting.

When Mr. Preston and his colleagues withdrew the Rev. William Hammett, chaplain, asked leave to appear before the faculty. He said there was very great excitement among the students, but he thought the most of them were desirous to retreat from the position they had assumed if they could do so with honor. The whole meeting would go with the three students it was generally understood the faculty intended dismissing. The chaplain implored the faculty, if it was consistent with its sense of duty, not to act against these students, at least not to do so before the present excitement had somewhat subsided. He had been informed that they were not as conspicuous members of the meeting as many others. ${ }^{2}$

${ }^{2}$ The Rev. William Hammett was an eloquent preacher of the Methodist denomination. He afterwards studied medi- 
The faculty decided not to take any special action against the three in view of the proof that they were no more concerned than others; assured the students that there was no thought of denying them the privilege of meeting and deliberating in an orderly manner, but emphatically repelled the claim that they could assemble when they pleased in any room without the faculty's permission, and maintained that the persons who broke open the door violated the law. "We do not conceive," responded the meeting, "that we have any right to break open any door in the University of Virginia." And there the matter was dropped. ${ }^{3}$

At some time in the session of I83I-2 a military company known as the University Volunteers was organized, and was allowed to exist on such terms as prevented its interference with more important matters. Of this first organization, Douglas $\mathrm{H}$. Cooper of Mississippi, afterwards a brigadier-general in the service of the Confederate States, was captain. He was succeeded by Robert Marion Deveaux of South Carolina. Thomas L. Preston of Virginia was the third in this office. James B. Watts of Botetourt County, Virginia, and John B. Guerard of Beaufort district, South Carolina, and Thomas H. Ellis, of Richmond, Virginia, were the first incumbents of the office of lieutenant.

About the only service ever seen by this company, which underwent yearly reorganization until 1836 , was in acting as escort to the orator who annually delivered a patriotic discourse on the Fourth of July

cine in Philadelphia, and practiced that profession, probably in Mississippi. A district in that State sent him to Congress.

${ }^{3} \mathrm{~A}$ participant, writing in the Jefferson Monument Magazine twenty years later, confessed that the students soon realized the mistake and that all were in great fear of expulsion. 
in the Episcopal Church in Charlottesville. In I833 the student thus honored was Richard Parker, whose distinction was emphasized by the attendance of the Jefferson Guards under Capt. Alexander Rives. Mr. Parker entered Congress, and was the Judge who tried John Brown at Charlestown in I859.

About the fall of 1836 some seventy students reorganized the company, and elected Thomas $\mathrm{H}$. Morris captain. Chairman John A. G. Davis communicated to the young soldiers the terms under which the organization could receive the sanction of the authorities: I. No violation of enactments to be allowed on parade or between the time of going on parade and being disbanded for the day; 2 . The uniform of the University to be worn; 3 . Neither the corps nor any of its members should fire their muskets on the Lawn or Ranges or near thereto, or permit any one else to do so; 4 . The members of the corps should not make any use of their muskets except in their regular military exercises; 5. It was to be distinctly understood that the faculty reserved the right of dissolving the corps for any violation on the part of the corps, or any of its members, of the foregoing conditions; and also whenever the interests of the University should, in their opinion, require it; 6 . Whenever, and as soon as, the corps was dissolved the muskets should be returned to the place of safe keeping in Charlottesville from which they were taken; 7. While the corps and every member of it was responsible for the fulfilment of these conditions the officers were considered as particularly so.

No notice was taken of this official pronouncement. Therefore Captain Morris was summoned 
to appear before the professors, whom he informed that his company had "neither agreed or disagreed" to the terms. The conditions were not regarded as binding and the right of the faculty to provide terms was denied.

When Captain Morris retired from the faculty room the professors had the issue distinctly before them-so placed with military directness. The opinion of the students was that they existed as a military company without the authority of the University and even in defiance of the objections of the faculty. The chairman was directed forthwith to inform the students concerned that they were not in fact a military company of legal organization, anc that those who had muskets in their possession and did not immediately remove them would be considered as violating the laws regarding keeping firearms within the precincts.

To this there was a prompt response in the form of resolutions adopted by the company. They were unambiguous: "Resolved, That the company is not disbanded; that the company will attend and drill as usual, what the faculty may say to the contrary notwithstanding; that every member of the company pledge his honor to stand by his comrades, and that action of the faculty against one shall affect every individual." In order that there should be no mistake about the persons who would be affected by faculty action against an individual a roster of the company was furnished to the chairman. It contained sixty-eight names. Two of the seventy were in "rustication" at Bowcock's Tavern for drunkenness and disorder and the other for drinking at Vowles's.

Chairman Davis and the faculty took decisive 
steps, but with cautious regard to all proper details. The janitor was sent to summon the student whose name stood first on the roster, the intention being to call before the faculty the entire company, one member at a time. "Dr." Smith returned and reported that the captain had informed him that "Mr. Walker was on parade and could not be spoken to."

The proctor was then sent with the roster to ascertain which of the students named on it were on parade and had muskets. An officer of the company obligingly called the roll by the proctor's roster, and all the students thereon but four answered and were bearing muskets. The proctor brought back the terms of another resolution by the company-"Resolved, That we have our arms and intend to keep them." The manner of voting aye was by "shouldering muskets." Every man shouldered his weapon.

There was no paltering with the "rebels ;" a resolution expelling them received every vote. The purview of the order of dismission recited that these students had introduced firearms and other weapons within the precincts without lawful authority and had avowed their determination to keep them in their possession therein notwithstanding the enactments of the institution and the express prohibition of the faculty. These offenses were held to be aggravated by the fact that they were a result of an illegal combination between the members of the company.

The announcement of the action of the faculty was made known at 4 o'clock on Saturday. It was followed by excesses which have been unequalled, and which constitute a very dark page, in the history of the University. The disorder was persisted 
in until late Sunday night, with many of the marks of the stupid frenzy of a mob. 'The professors' houses were attacked, the doors forced, the windows broken, and the inmates regarded themselves as in serious danger of personal violence. Firearms-especially muskets - were discharged everywhere and at frequent intervals. The institution was without police, and there was no means at hand with which to control the mob. The civil authorities intervened, stationed armed soldiers at the Rotunda and at other points in the grounds, and instituted an investigation.

On the Igth of November-a week after the beginning of the disorder-a meeting of students was "held at the Rotunda" at which John W. Harris presided and Walter Gray acted as secretary. It was well attended and its action was unanimous. The sentiment of the meeting was embodied in a preamble and resolution, which were laid before the faculty. The preamble averred that serious consequence had already attended the disagreement between the faculty and a large part of the students, and expressed apprehension of more unfortunate effects; set forth the belief of the meeting in the integrity and sincerity with which the views of the members of the military corps were entertained, despaired of an adjustment between the students and the faculty and proposed that "the origin and progress of this unhappy difficulty should be calmly and deliberately reviewed either by a full session of the Board of Visitors of the University or by an enlightened and impartial public opinion." "The resolution pledged them to an individual responsibility under the statutes of the institution so that if the point of authority involved-that is, the right of 


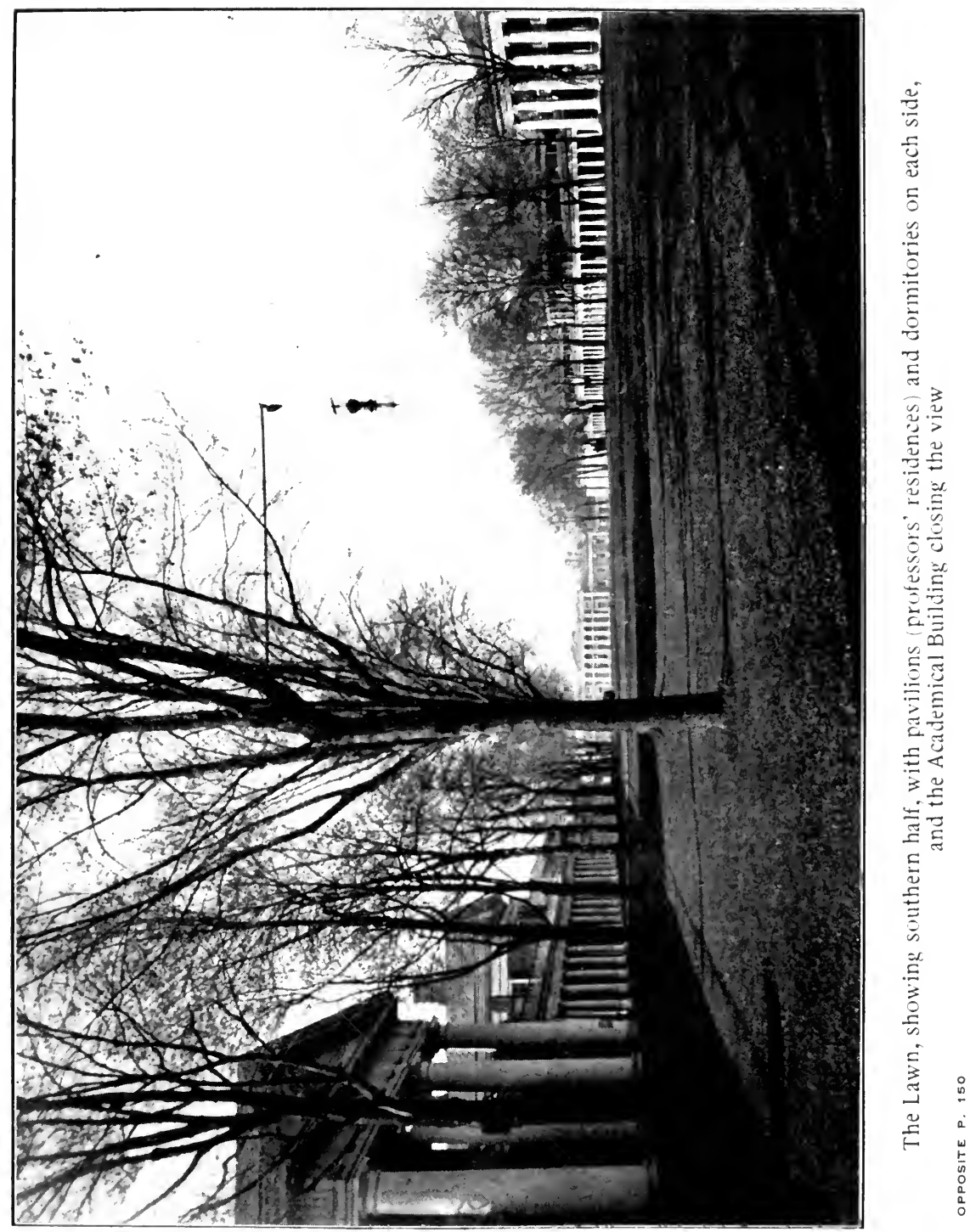




\section{UIJ3RALK
OF THE UNIVERSITY}

CALIFORNIA 
the faculty to disband the company unless it complied with the proposed conditions-should be decided against them they would acquiesce cheerfully. Pending the appeal no arms would be used in the University.

Under the enactments the sentence of dismission to be final had to be approved by the Visitors, but the case was never reviewed by them. No doubt a full report was made by the faculty, but even this fact does not appear in the minutes of the board.

Notwithstanding all that had taken place, the memorial of the mass meeting was received in a conciliatory spirit by the faculty, and the chairman (Professor Davis) proposed a very generous course in the following preamble and resolution:

"Whereas the students of the University, in a full and general meeting assembled, have unanimously represented that the said dismissed students committed the act for which they were dismissed under the impression that they were authorized to do so by the laws of the institution, and propose in their proceedings to obtain the sense of the Board of Visitors of the University as to the true construction of said laws, and in the mean time pledge themselves that no arms shall be introduced within the precincts; and whereas, whilst the faculty are perfectly satisfied of the correctness of their own construction of the laws, and of their duty to enforce them according to their construction, they are nevertheless willing for the reasons above stated, and under the special circumstances of this case now to readmit the above named students; therefore, Resolved, That those students who think proper to return, of those dismissed as aforesaid, be readmitted."

The vindictive spirit attributed to the chairman 
by the students and their partisans does not appear in this proposal of amnesty; instead, there is forgiveness of all outrages and insults that followed the act of dismission. But not all of Dr. Davis's colleagues agreed to go to this length with him, and some of them insisted on giving weight, in their compromise, to the acts of insubordination which had wrought so much injury to the institution. Accordingly, Dr. Emmet proposed to add this condition: "Upon application to the chairman of the faculty and upon disclaiming any participation in the principal acts of riot and violence." But the vote was taken upon Dr. Davis's plan as submitted, and a majority of one appeared in the negative.

The chairman knew that if his plan of amnesty was adopted with Dr. Emmet's amendment no student could re-enter and he succeeded in having added these words, "or, if they cannot disclaim such participation, making proper atonement therefor." In this shape the resolution of readmission received the sanction of the faculty on the $22 \mathrm{~d}$ of November.

Just what the mass-meeting meant by its offer to submit the question at issue to an "enlightened and impartial public opinion" is not clear. If the phrase described a purpose to publish a statement and leave the public to make up its judgment from the facts and arguments thus communicated the unexpected course of the faculty in offering terms of peace which a man of honor in almost any situation could accept did not prevent the preparation and publication of such a brief by a committee, not of the massmeeting, but of the company. A profound impression was made by the summary dismission of so large a number of students, many of them among the best of the University, and a sentiment adverse 
to the institution became rather general. Some of the newspapers, condoning the severity of the faculty; strengthened this sentiment by espousing the cause of the dismissed. When the resolution providing for conditional readmission was made known it was condemned for its mildness! These contradictory impulses called forth Chairman Davis's pamphlet entitled "An Exposition of the Proceedings of the Faculty of the University of Virginia in relation to the Disturbances at that Institution," a masterly plea as well for the necessity of severe treatment of the students while in rebellion as for the forgiving policy put in force when the ends sought by punishment had been attained. His defense of the conciliatory course of the faculty concludes his "Exposition":

"This resolution was not passed until the arms had been removed out of the precincts, and an assurance had been given by the whole body of students that they should not be again introduced, unless the Visitors of the University should authorize their introduction. And it would not have been adopted then, but for the many good students among those dismissed, and their peculiar situation. They had, many of them, become involved in the difficulty under circumstances which, together with their previous characters, constituted a strong claim to our indulgent consideration. But these students, although desirous to return, were prevented by the pledges into which they had inconsiderately entered from doing so on any terms by which a discrimination should be made between themselves and others. Gentlemen of great respectability and intelligence, the fathers of some of the dismissed students, who came to the University to obtain the readmission of 
their sons, in view of this state of things, earnestly recommended the course which was adopted, as the only one which would place it in the power of any student, however exemplary his character or mitigated his offense, to re-enter. And the company being now disbanded and dispersed, the arms removed, and a pledge given that they should not be again introduced, it was believed by the faculty that they might now allow those who had been dismissed to re-enter, on the terms prescribed in their resolution, without impairing their just authority. Discrimination between those engaged in the outrages, and those not so engaged, which under other circumstances would have been proper, under existing circumstances could not be made without defeating the object in view. Besides, as there was reason to believe that those whom the faculty would desire to exclude would not apply for readmission on the terms prescribed, such discrimination was unnecessary with a view to their exclusion; whilst in truth, it could in no other manner be so effectually made as by the resolution adopted. By that resolution, the combination which had otherwise succeeded, at least so far as to involve all in a common fate, was broken and defeated in respect to that object, as it had previously been defeated in its primary object of resistance to the faculty. The resolution of dismission was not rescinded; but its purpose having been attained in the enforcement of the laws, and in teaching it is hoped a salutary lesson for the future, the exclusion from the University produced by it, and which from the nature of the sentence was not perpetual, was taken off on compliance with certain conditions." 


\section{CHAPTER XIII}

\section{ASSASSINATION OF PROFESSOR DAVIS}

Shot Down in the Dark-Story of the Event by a StuDENT of That Day-Suspicion, PuRSUIT aNd ARRESTSTUDENT COOPERATION WITH THE OFFICERS OF THE LAW - Simms BaIled-Never APPEAREd FOR TRIAI-MORE Disordetrs-ANother APPEAL to THE CiviL, AUThorities -Mr. RIVES Proposed a Presidency for the UNIVERSITY.

The annual celebration of the I2th of November, the date on which the military corps reached the climax in its defiance of the faculty and met the supreme exercise of University authority with rioting, was a display of bad judgment and ended in tragedy. Chairman Davis, whose hand had drawn the paper under which the rebels were readmitted to the benefits of the University, was shot down in front of his home at about Io o'clock on Thursday evening, November I2, I840, and died of the wound on the following Saturday.

Professor Davis lived in Pavilion X, at the southern end of East Lawn. He was disturbed by the firing of pistols, and left his office and procuring his hat in the hall went out on the Lawn. At the door he paused to inquire of one of his servants, a colored boy of thirteen, who had been watching the masqueraders as they moved about the Lawn, where the disorderly students were at that moment. They had gone toward the Rotunda, and Dr. Davis passed into the dark, and the colored boy saw no more of him for some time. After fifteen or twenty minutes the boy, still standing in the shadow near the Pro- 
fessor's door, saw a flash and heard a report of a pistol a few feet beyond the large columns of the portico under which he was standing. The next moment a masked figure ran by him. The boy stood for a minute awaiting the next step in the progress of the disorder; but he became puzzled as to the whereabouts of his master, and went cautiously out of the circle of dim light into the darkness on the Lawn. A dark object on the ground caught his attention, and a low groan made him afraid. He knew the figure on the ground was that of his master, lying prone on his face. "Can you get up, sir?" "No, I cannot get up. Go in the house and tell them I am shot."

Boy-like he went straight to his mother in the kitchen with the terrible news. With rare good sense, she sent him across the Lawn to tell Mrs. Tucker-the wife of the professor of moral philosophy - to come over before she told Mrs. Davis. Bidding Mr. Tucker to follow, that lady hastened to Mrs. Davis.

In the mean time some students had carried Professor Davis into his house, and summoned a physician. Dr. James L. Cabell, a colleague, responded. The young men, eager to apprehend the assassin, asked the stricken man if he knew who shot him. He said he knew perfectly well, but refused to give his name. All of the University was at the door awaiting, in feverish excitement, the verdict of the surgeons. This seemed favorable, but Mrs. Davis utterly rejected the honest assurances of Dr. Howard that her husband would be well again in a short time. Dr. Cabell was rather reserved in the expression of an opinion.

Dr. Robert Lewis Dabney, the philosopher and 
theologian, was a student at the University, and was one of those who stood at the door while the doctors were probing for the bullet. He wrote of the affair to his brother the following day: "There were only two rioters seen," he said, "who had been firing blank cartridges about the doors of the professors, masked and disguised. The two passed freely within a few feet of the peaceful students, completely concealed by their disguises, when one of the students told them to take care, as Mr. Davis was on the watch, near his house. One of the two immediately walked down that way, loading his pistol; but, in addition to the former charge of powder, he was seen to put in a ball, ramming it down against the wall of the house as he went. Nobody at that time, however, suspected anything, or felt himself authorized to interfere. A few moments after another report was heard, and the masked figure was seen making off across the Lawn. Some of the students heard groans, and going out, found Mr. Davis down and unable to rise. He said that he had gone out to preserve order; that he saw the masked figure, attempted to take hold of him and take off the mask, but that he dodged him, retreated a few yards, and then after he (Mr. Davis) had ceased to pursue, turned and fired. * * * The excitement among the students was so grcat, and everybody was so horrorstruck, that no immediate steps were taken to secure the criminal. The action was so atrocious that it is impossible to conceive a motive, and still the circumstances are such that we cannot believe it to have been accidental, which we would gladly do if we could."

Suspicion fell upon Simms so strongly that the students sent a committee in search of him. He 
was found, and admitted that he had been one of the rioters, but denied any share in the assault on Professor Davis, and refused to give any information whatever as to the disguises or purposes of his associates in the disorder. The committee had no legal authority over the person of the suspect, and could only exact a promise that he would not leave the University. He absconded, nevertheless, pursued by students and the civil authorities.

The next day lectures were suspended. Early on that morning the students in mass meeting offered to cooperate with the county authorities in the capture of the fugitive suspect, and in any undertaking the object of which was the arrest and conviction of the criminal. In the mean time, another student, a Southerner named Kincaid, had fallen under suspicion, and a warrant for his arrest was issued upon the testimony of Robert L. Dabney. There was no officer at hand to serve it, all being in pursuit of Simms, and young Dabney and another student were deputized. It was expected that the arrest would be opposed with violence, but Kincaid made no resistance.

The students scoured the country for Simms, resolved, as they said, to have him if he was to be found. He was found two or three miles in the country, concealed in a grove of pines, and eventually committed to jail. Kincaid was bailed under a bond for $\$ 5,000$ for his appearance at the trial. The Commonwealth's attorney, Valentine W. Southall, tried to bring the case to a speedy hearing, but the prisoner's lawyers, Messrs. Leigh, Lyons, and Gilmer, on some plea, secured a continuance at the May term of the Circuit Court. Then followed an effort to procure the 
release of the accused on bail, but the motion was firmly denied by Judge Lucas Thompson. The attorneys were more successful in the general court, where medical testimony was produced to show the prisoner's precarious state of health. The physicians examined were Drs. James L. Jones, Carter, and Massie. Bail was allowed in the sum of twenty-five thousand dollars, Reuben Grigsby and B. F. Porter of Rockbridge, and William Porter of Orange, becoming surety.

The physical condition of the prisoner was certainly very bad. When liberated he started on his long journey home on a bed placed in a stage, which had been chartered for the purpose. He never appeared for trial and his large bond was forfeited. The report that he committed suicide within a year is probably true, but another story is to the effect that he went to Texas to evade trial, and died there soon after.

One would think that consequences so terrible would have discouraged rowdyism for a long time to come. But there was still a persistent element. Late in the year I844 a band of this class of the students was organized to create noise and disorder, and the official records bear testimony to their success. With horns and other instruments of torture, and in disguise, they paraded the Lawn and other parts of the precincts at a late hour of the night, making rest impossible and waking hours hideous.

These parades took place at intervals of about ten days, and although subversive of the peace and good order of the University were not attended by any outrages on private dwellings or 
public property. This company, known as "The First Band," contained a number of otherwise exemplary students who were probably to be credited with its informal disbandment. Another band was organized. Unlike all preceding "riots," there was no pretense that it was caused by a grievance, and the only purpose in view, according to testimony, was to force the closing of the session some months before the usual time for its termination. But on the 24th of February three students were suspended from the University for disorderly conduct at one of the hotels, and immediately the "band" paraded-it had its pretext at last. The disorder went to the extreme length of attacks on the hotel and the home of Chairman Rogers, in the course of which a door and windows were broken. These emeutes were of almost nightly occurrence. On one occasion stones and other missiles were thrown against the parlor window of a professor's dwelling while ladies were sitting in the room; on another some rioter tapped upon the shutters of a window at Professor Robert E. Rogers's, frightening Mrs. Rogers. The professor was out at the time and on his return found his wife very much agitated. The party of "serenaders" were returning and Professor Rogers took his station behind one of the columns in the alcove in front of his housePavilion VIII. As the "musicians" passed on, making their infernal din, one of the band approached the door and was about placing his foot on the mat when the Professor seized him by the cloak, and allowing him a little rope, actually picked him up in the presence of the whole crowd 
and carried him into the parlor, where the ful! blaze of the lamp disclosed who he was ${ }^{1}$. Pistol firing was indulged in by disguised students, while others galloped through the alleys and arcades of the University on horses procured, in some instances, by breaking into private stables in the night-time. The license became more unrestrained, dwellings were attacked, windows broken, and the doors of the Rotunda forced.

The faculty then appealed to the civil authorities, and placed the public property under their protection. The court of justices and a jury convened at the University April 21, I845, and directed the sheriff to place a guard of armed citizens at the Rotunda, where it remained two nights. When the disorderly students learned of the proposed intervention of the civil authorities they held a mass meeting-which was not fully attended-and resolved to evade the court or resist it as far as possible. The warlike spirit was not offensively exigent at any time after the constables appeared on the scene. The turmoil of months came to a peaceful end-except for those participants against whom the faculty afterward found conclusive evidence. That they were dealt with quite firmly the faculty minutes-covered over with sentences of suspension, dismission, reprimand, and admonition-afford overwhelming evidence.

In January, 1846, the legislature sent a com. mittee to the University to investigate, and the Visitors convened at the same time. The legislators submitted a series of questions in regard to the possibility of smaller compensation for the professors, the reduction of the number of em-

${ }^{1}$ Life and Letters of William Barton Rogers, Vol. I, 240. 
ployees, the wisdom of admitting some students from Virginia free of tuition, and the causes of the recent defiance of authority on the part of many students. The answer of the Visitors to the inquiry as to the probable causes of the outbreaks was "that the riots which occurred in April last were mainly attributable to the insubordination of the parties implicated, urged on by disorderly and dissipated students who remained in the neighborhood after having been dismissed from the University, and who themselves were believed to have committed the greater part of the injury done to the buildings, as appears by evidence collected by the court of justices which met to inquire into said riots."

But this answer did not go far enough, in the opinion of William C. Rives, ${ }^{1}$ one of the Visitors, who tried to have the following substituted:

"In answer to the fifth inquiry of the committee, to wit, 'Whether the frequent breaches of discipline by the students of the University, and especially the late riots, are attributable to the insubordination of the students, a defect in the system of regulation, or the inability of the authorities of the University to enforce them'-the Board of Visitors are of opinion that the breaches of discipline, and especially the late riots, alluded to by the committee, are attributable to the combined operation of all the causes indicated in the above inquiry. In the origin and progress of the late riots, a very reprehensible spirit of insubordination was manifested on the part of a certain number of students; but the Board of Visitors feel constrained, in the impartiality of the high office

${ }^{2}$ Minister to France. 
with which they are charged, to state that in their judgment some unfortunate errors, to say the least, were committed by the executive authority of the University in the manner of proceeding in regard to these disturbances, which contributed both to prolong and to aggravate them, and finally to involve in the censures and penalties inflicted by the faculty many young men of unexceptionable general deportment and guiltless of any participation in the disorderly occurrences complained of. But the Board of Visitors, believing that the breaches of discipline referred to by the committee are, in great part, to be traced to a deeper and more lasting source in a fundamental defect in the government of the University, are of opinion that a new organization of its authorities is greatly to be desired, which would assign to the executive administration a permanent and responsible head in a president, charged with the moral discipline, supervision and general management of the University, standing in loco parentis to the students and having his own character, by singleness and elevation of his position, indissolubly identified with the character and good order of the institution. Such an organization the Visitors are persuaded would furnish by far the best, if not the only, remedy for the breaches of discipline which have hitherto occurred in the University; and as some doubts have been expressed as to the competency of the Board of Visitors of their own authority to institute the proposed change, they strongly recommend that provision be made for it by law."

This substitute, which the Visitors rejected, sought the establishment of a presidency because, 
in the opinion of its author, the administrative problems of the institution could not be overcome otherwise. Twenty years elapsed before it was again considered-and then other motives were responsible.

Another story goes with this turbulent decade. A strolling menagerie was exhibiting in Charlottesville near Maplewood Cemetery. Many students attended, and among them was John A. Glover, of Demopolis, Alabama, who was leaning against the barrier ropes stretched around some cages in which a showman was performing with a lion. Perhaps the students, as was characteristic of them sixty years ago, were somewhat disorderly, and certainly they had been requested to observe perfect order during the act then in progress, in order to reduce the danger to a minimum. At a critical moment Glover tossed a lighted cigar at the animal. The outraged showman sprang from the cage and felled Glover with a tent pin. The injured man was taken to the Eagle Hotel (now the Colonial), where he died in two or three days (April I I, I846). He was buried in the University Cemetery, and his grave is marked by a monument erected by his fellow students.

Another incident may close this chapter on the wild days of the University. John Singleton Mosby, afterwards distinguished as the leader of the famous band of fighters in the battles of the Confederacy known as Mosby's Rangers, was the chief actor in an affair which narrowly escaped tragic consequences. In an altercation in March, I853, with the son of George W. Turpin, who kept the Monticello Hotel, Mosby, then a youth of twenty, used his pistol with such effect that young 
Turpin was dangerously wounded. Mosby was arrested, prosecuted by the late William J. Robertson, fined $\$ 500$, and sentenced to jail for a year. The young prisoner, using his attorney's books, studied law diligently, and a year after his release was admitted to the Albemarle bar, but he soon removed to Abingdon. 


\section{CHAPTER XIV}

\section{THE HONOR SYSTEM}

Student Freidom and Responsibility-Trivial Nature of MANY OFFENSES-EXTRACTS FROM THE FACULTY MINUTES-SOCIAL CUSTOMS AND THEIR INFLUENCE-ForEIGN PROFESSORS OUT OF TOUCh-Wavering LOYAL,TY TO JEFFERSON'S IDEALS-SPIRIT OF HONOR-EvolviNG AN UNWRITTEN CODE.

Among the first enactments there were only two of far-reaching consequence. The first of these was: "When testimony is required from a student it shall be voluntary and not on oath, and the obligation to give it shall be left to his own sense of right"; and the other: "Every student shall be free to attend the school of his choice and no other than he chooses." These regulations conferred upon the student a noble freedom and a high responsibility whose tendency, in the natural and proper course of things, would be to add dignity and strength to his character. If the founder of the University could have lived through its first decade in the midst of the students as the professors did, there would have been an early realization of the ideal results he sought. Bad judgment, however, postponed them a third of a century.

If the early professors understood Mr. Jefferson's object fully and approved it in any measure, their attempts to realize what he believed would come to pass were made with little skill. Any one who turns the thousands of pages of the minutes of the faculty meetings during the first thirty years of 
disorderly conduct by singing a corn-song within and without the precincts on Sunday evening last, Resolved, That they be reprimanded by the chairman, and the guardian of the former and the father of the latter be written to on the subject."

"The chairman [Professor Bonnycastle] said that he was informed that there was a champagne party at Keller's confectionery a few evenings since, which induced him to sit up later than usual to see if he could ascertain any of the students concerned in it. About ten o'clock a party of students came into the University singing an indecent corn-song. He saw one open Mr. R. K. M.'s door and go in. He immediately followed the person into the room and asked Mr. R. K. M. if he was not one of the party. He confessed it." M. was suspended for one month.

Corn-songs, "the rag-time" melodies affected by students in the early years of the University, seem to have shocked the European professors. In slavery times the autumn brought on the festivity known in the South as corn-shucking. The store of corn was heaped up in a great pile in a convenient place, and the owner gave notice of a husking on a night named. A late supperalways a good one-and usually an abundance of whiskey were provided. All night, or until the corn was shucked, the negroes stripped the husk from the ears and sang plantation melodies. The singers were usually lead by the best vocalist, who strutted about on the piles of corn, his head adorned with a shuck.

"The chairman informed the faculty that $\mathrm{Mr}$. Wm. J. Robertson obtained leave to attend church in the University on Sunday last without uniform. 
That he wore a coat on that occasion which the proctor believed was new, and that the inference was that Mr. R. had recently purchased this coat in violation of law. On being summoned before the chairman this presumption was strengthened by Mr. Robertson's refusing to answer any questions. Mr. R. was then summoned before the faculty, appeared and refused to answer any questions in relation to the charge of having purchased a coat not uniform. Mr. Tucker proposed the following resolution, which was seconded and passed: The faculty having satisfactory evidence that Mr. Wm. J. Robertson on Sunday, the $4^{\text {th }}$ inst., wore a new coat which they had reason to believe he had purchased contrary to the enactments prescribing uniform,-and he failing to repel the presumption by any counter testimony, therefore, Resolved, That he be suspended for one week and required to go to Bowcock's."

The William. J. Robertson thus rusticated was afterward judge of the Supreme Court of Virginia and ranked probably as the first lawyer in learning and ability in his native State.

"The chairman informed the faculty that on the night of the $4^{\text {th }}$ inst., about half past I I o'clock the proctor in passing the room of $\mathrm{Mr}$. — heard the following remarks made by persons in said room-'Hearts are trumps!' 'Play on, Shannon!' 'I hold low!' From these remarks, as well as the sounds which the proctor heard like that of cards being played on a table, he was certain that the game being played was cards. The door was locked and some little time elapsed before he gained admission. In the mean time he heard something like the shuffling away of cards. 
On being admitted he found in the room $\mathrm{Mr}$. $\longrightarrow, \mathrm{Mr}$. $-\mathrm{Mr}$. $\longrightarrow$. These gentlemen looked confused; denied that they had been playing cards." The charge was investigated by the faculty, but no more evidence was elicited. Upon the testimony of the proctor, who knew no more than he had heard while listening at the door and reported to the chairman, these students were dismissed for the remainder of the session! This and similar cases seem to justify the legislature in refusing to establish a court in the University with professorial magistrates empowered to arrest, try and punish students.

"The chairman informed the faculty that Messrs. Beverly Tucker and John G. Peyton were present at a festive entertainment (eating party), of which the former gentleman is supposed to have been the provider, given in the room under the old library. These gentlemen were sent for. Mr. P. appeared and stated that the entertainment was a turkey supper. No wine or spirituous liquors were drunk, the beverage being coffee. He had nothing to do with furnishing, but was merely a guest. Mr. T. said that he was present and contributed to provide for the party to the amount of four dollars. The whole cost was eight or nine dollars. T. was reprimanded and his father informed and R. was admonished."

Beverly Tucker was afterward United States Consul at Liverpool, and served the Confederate Government as a confidential agent.

It would be idle to contend that in this new University there were no faults to mar its history. There was drinking, and there was gambling, and it would be matter of amazement if there had not 
been. Both were social vices of general prevalence. Wherever there was a mahogany sideboard there was also a well-filled decanter to which every one was free to resort. From homes like this the students came, and they were not at all prone to believe that a social practice sanctioned by their mothers was so vile after all. When they "indulged" at Vowles's, or "took something comfortable" at Keller's confectionery, they felt that the act was the same as when they drank a glass of Madeira at home, except that the scene was changed.

- It was not quite the same with gambling. They had not actually been afforded the opportunity at home of risking their pocket money and credit at loo or "all-fours." Gaming was a man's sport, a gentleman's pastime, and society suffered if it did not sanction it. At the University they felt that the time had come to assume the vices of full grown men, and some of them did so.

The foreign professors were not in touch or sympathy with social practices in the Southern States. With them gaming was a vice and drinking equally so. No doubt Dr. Blaettermann drank his beer, but his beard had grown-he was not a boy. The American members of the faculty were in sympathy with all measures of repression. These young men who indulged in mint-sling and toddy, and played loo behind locked doors, at which proctors, "in passing," sometimes paused to listen, ought to be measured by the standards of their own day, and then it will be found that instead of constituting a group unique for their vicious lives they were about the average of 
spirited youths under the disadvantage of too much pocket money.

The policy of ferreting out all suspicious cases and allowing none of them to expire by limitation kept the faculty in almost constant session as a punitive court. The students summoned before them were a very small part of the matriculates, but the trials were attended with difficulty because the witnesses, if students, could testify or not as they chose. This did not constitute the extreme difficulty because the faculty, as the cases above indicate, seemed not to hold itself bound to prove the guilt of the accused. A frequent phrase in the way of preamble to a sentence of dismissal was, "it appearing to the satisfaction of the faculty"-which meant that the faculty was convinced of the guilt of the person under charges, although the guilt was not established by direct testimony or even by circumstantial evidence. But it was not a satisfactory method, and in I828 the faculty considered a motion to expunge the law which exempted the student from testifying on oath.

The Board of Visitors in July, I832, gave careful consideration to Mr. Jefferson's rule, but there is nothing in their minutes to show how the individual members stood on this question. Those present were Cabell, Cocke, Breckinridge, Brodnax, and Randolph. They were perplexed by the conditions. It was with their knowledge that the guilty were punished without adequate proof, for the student who knew the facts shielded the wrongdoer by refusing to testify, making an ignoble use of the freedom Jefferson had given him. The end of their consideration was that the Visitors did not 
repeal the rule, but they passed an ordinance which nullified it, in effect, by conferring upon the faculty the power to require any student to state on his honor whether he knew the perpetrators of any violation of law under consideration, under pain of any of the penalties, including expulsion, if he refused to testify. This power to compel testimony on honor was made applicable to the investigation of past as well as future misdemeanors. The retroactive character of the ordinance was regarded as peculiarly offensive.

A somewhat careful investigation has failed to discover a case in which a student was coerced into testifying. Under the leadership of Professor Davis the faculty declared by a formal resolution that this enactment "should be enforced with great caution, and only in cases of serious and flagrant violations of law," and in no event should it be resorted to until the faculty had determined by vote that the case was a proper one in which to enforce it. The law had a single year of existence, for the Visitors in July, I833,- the same members present except that Breckinridge gave place to Johnson,-expressly repealed their ordinance providing for testimony on honor, and Jefferson's rule was restored, and is still the law.

The faculty wavered in its loyalty to Mr. Jefferson's ideals, certainly in so far as his theories concerned discipline and all that is meant by the intimate association of students and the frequent contact with them of professors and officers. The board wavered likewise, and in this condition of things the growth of a compelling public opinion was very slow indeed, but it grew. A large percentage of the students devoted themselves so ear- 
nestly to the purpose for which they entered the University that they had little time and little inclination to clash with the authorities. These men were in pleasant social and official relations with the professors and were inevitably impressed with the noble characters of the men who composed the faculty. They saw that, while cognisance was taken of all offenses and punishment was administered with a firm hand, the truthful and highminded, even when in fault, were treated with consideration, and the really penitent were dealt with forgivingly.

Through all this complexity lived a spirit of honor which eventually became the saving grace of student life and character at the University of Virginia. A law of honor was evolved, an unwritten code, of sources difficult to identify with perfect certainty. Assuredly in part it is rooted in Jefferson's trust as expressed in his law as to student testimony. It was powerfully vitalized by the sacrificing lives and labors of nearly all of the men who filled the chairs in the University during the first thirty years of its existence.

As understood elsewhere the honor system means that at Virginia there is no espionage during examinations and that the integrity of the papers upon which the student is graduated is insured by the written pledge that he has neither received nor given assistance. The honor system germinated long before July 4, I842, when Professor Henry St. George Tucker offered and the faculty adopted the following resolution :

"Resolved, That in all future examinations for distinction and other honors of the University each candidate shall attach to the written answers pre- 
sented by him on such examination a certificate in the following words: I, A. B., do hereby certify on honor that $I$ have derived no assistance during the time of this examination from any source whatever, whether oral, written, or in print, in giving the above answers."

But this action of the professors-which was a vote of confidence-powerfully promoted the growth of a chivalrous regard for the claims of honor. The unexpected happened when the students by impulse rather than premeditation made the protection of the privilege their own care, and in more than sixty years the faculty has had no share in applying a penalty when their trust was abused.

"She mixed her ancient blood with shame" does not describe a more veritable social outcast than is the student who cribs ${ }^{1}$ or cheats on examination. The guilty one slinks away, suddenly conscious of the awful force of public sentiment.

But the chivalry of the students is concerned with more than the punishment of cheating on examination. It does not demand wealth, or any other accident, as proof of eminence-nor does it demand leadership or scholarship. Shrinking modesty and awkward ignorance are not regarded as conferring the right to molest, but a student whose instincts are so coarse that he is capable of studied rudeness or insult to women, cheating at cards, the indescribable meanness of petty theft,-in a word, who forgets to be a gentleman in all his dealings, - is made to understand that he is not fit to associate with young men of honor and will not be allowed to lower the

\footnotetext{
${ }^{1}$ The verb to crib is not in use here. To cheat is not a polite one, but it has the desired meaning.
} 
moral tone of student life by remaining longer in the University.

The great apostle of liberty did not fail to excite at his University a strong attachment to human rights. His professors believed in them, the students were jealous of them, and a result is that in this respect there is no difference between first year and last year as far as the student's consequence is concerned. The rights of the raw matriculate are as sacred as those of the old student who is doing graduate work and will be defended as promptly. In such an atmosphere hazing has never occurred, could not survive. The infliction of indignity and injury on a "new man" by a gang of associated bullies would be impossible. Such an association could not be consciously formed in defiance of the manly public sentiment which exists here, and if fatuously attempted in ignorance would be resisted by voluntary defenders of the assaulted student.

While a student's consequence in the University of Virginia is not determined by any formal reference to his antecedents, of course his antecedents may have the determining effect heredity exercises. No psychological court sits in judgment to destroy the force of any law of human nature, but the courts of public opinion are always open to pass upon the conduct of men and award the station they earn by talent, industry, or good or evil conduct. The judgment of the campus is unerring. Naturally the student's consequence in this arena is at its lowest state in his first year. He has no brief in the hands of his judges. But as time passes evidence increases and the student grows in regard or disfavor according to his deserving. In the end every man goes to his place; accident of birth or wealth cannot put him in any other. 


\section{CHAPTER XV}

THE JEFFERSONIAN GROUP OF BUILDINGS

Delineation of the Grounds-In Search of Architectural, HINTS-JEFFERSON AND THE ARTS-PALLADIO'S CONTRIbUtion-Specifications for the Corinthian Capital,sPantheon as a Model for the Central BuildingsRAPHAEL'S ScHOOL, OF ATHENS-LATER BUILDINGS.

On the $5^{\text {th }}$ of May, I8I7, Mr. Jefferson presented to the Board of Visitors a plan for erecting a distinct pavilion or building for each separate professorship and for arranging them around a square. With the certainty that characterized all his purposes he suggested and the Board approved the drawing of parallel lines, and the locating of the pavilions on one or the other of them. In time one of these lines became East Lawn and the other West Lawn. The proctor was empowered, as soon as the funds were in hand, to "agree with proper workmen" for the building of the first pavilion, and for the erection of dormitories to a number not exceeding ten on each side of this building. The erections were to be of "regular architecture."

Four or five days after this meeting Mr. Jefferson wrote to a friend in whose architectural taste he seems to have had confidence and asked his assistance: "We are commencing here the establishment of a college, and instead of building a magnificent house which would exhaust all our funds, we propose to lay off a square of about 700 or 800 feet, on the outside of which we shall arrange separate pavilions, one for each professor and his scholars. 
Each pavilion will have a school-room below and two rooms for the professors above; and between pavilion and pavilion a range of dormitories for the boys, one story high, giving to each student a room Io feet wide by I4 feet deep, the pavilions about $3^{6}$ wide in front and 24 in depth. The whole of the pavilions and dormitories to be united by acolonnade in front of the height of the lower story of the pavilions, under which they may go dry from school to school. The colonnade will be of square brick pilasters (at first) with a Tuscan entablature. Now what we wish is that these pavilions, as they will show themselves above the dormitories, shall be models of taste and good architecture, and of a variety of appearance, no two alike, so as to serve as specimens for the architectural lectures. Will you set your imagination to work and sketch some designs for us, no matter how loosely with the pen, without the trouble of referring to scale or rule; for we want nothing but the outline of the architecture, as the internal must be arranged according to local convenience. A few sketches such as need not take you a moment will greatly oblige us. We have to struggle against two important wantsmoney and men for professors capable of fulfilling our view. They may come in time, for all Europe seems to be breaking up. In the meantime help us to provide snug and handsome lodges for them."'

Some time before October of that year ground

${ }^{1}$ Unpublished letter to Dr. William Thornton. Apparently Mr. Jefferson had not at that time settled on Palladio's drawings as his source of supply. One thing is established-that as early as May, I8I7, he had fixed upon pavilions connected by dormitories, both fronted by a Tuscan colonnade. A rough drawing accompanied this letter showing pavilions and dormitories on three sides of a quadrangle. 


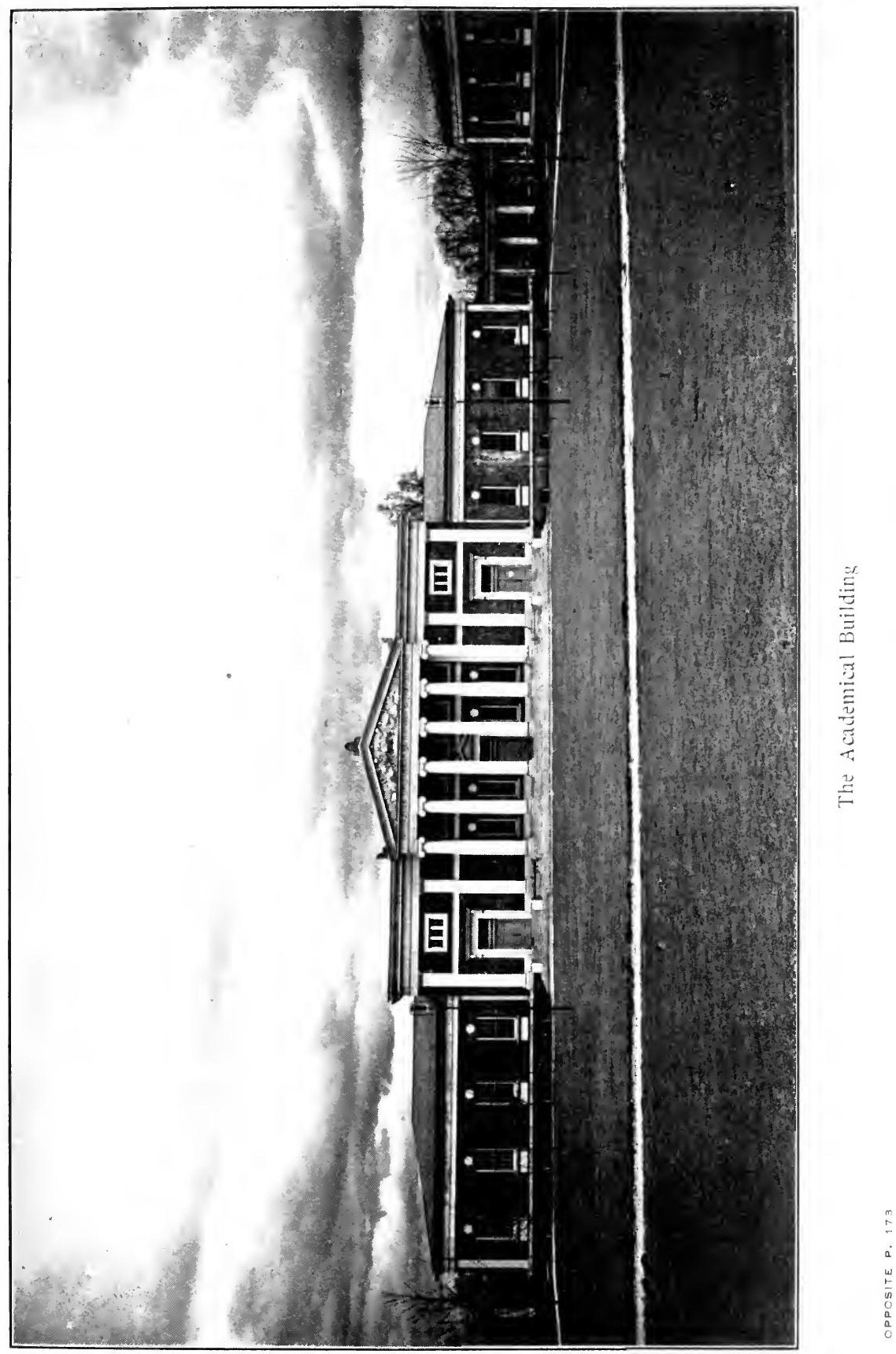



was broken for the first of all the buildings in what afterward became the University. "We have now got our building to the surface of the ground and to-morrow [October 6, I8I7] being the periodical meeting of the Visitors, and also that of our county and district courts, the ceremony of laying the first stone will take place."

This was Pavilion VII, which was at first used as the library and in which the faculty was accustomed to meet in the early days of the University. It was often like a police station and police court combined, and many a student was called before the grave professors who sat in awful judgment upon the peccadilloes of indiscreet collegians. The Board of Visitors found it a suitable place wherein to sit through their long and important sessions. For this particular use it was specially fitted up and furnished in pursuance of an order entered in 1833 .

The board hastened matters as much as possible. At its October meeting in 1817 it was much encouraged by the prospect of a substantial income from the subscriptions then being taken for the Central College building fund, and two pavilions and more dormitories were arranged for. More than a year went by, and then engagements were authorized for two or three more pavilions, and so on until they were all in the hands of carpenters, bricklayers, plasterers, etc.

Among some old papers containing scores of memoranda in Mr. Jefferson's writing the following rough draft of a report to the Board of Visitors by the proctor, A. S. Brockenbrough, under date of

${ }^{2}$ Unpublished letter to Samuel J. Harrison, dated October 5, 1817 . 
October 5,1822 , contains these interesting statements :

"I have the satisfaction to state that the ten pavilions intended for the professors are now almost entirely finished, the wood work of them is completed, the plastering and painting of seven of them is done, and the other three will be plastered in a few weeks. The wood work of all six of the hotels is finished, three of them on East street are plastered and painted; the other three on West street are lathed and will be plastered this fall. Of the Io9 dormitories 97 are plastered, the balance are partly lathed and plastered so that there is no question but they will be finished this fall. The serpentine garden walls between the western range of pavilions and hotels will be finished in two weeks, and if the weather permits the garden walls on the opposite side will be run up.

"Considerable progress has been made this summer in digging and leveling the gardens and streets. By the end of the year we shall be nearly through that kind of work. I therefore presume it will not be necessary to employ as many laborers the next year for the business of the institution."

It is well known that the hotels were built on lines parallel to those on which the professors' pavilions were located, that these new rows became East Range and West Range, and were united by arcades.

Brockenbrough's memoranda are interesting as indicating in detail the progress of the buildings in the fall of I822. For grounds, buildings, etc., about $\$ 226$, I6I had been spent according to a report of December 23, 1822, and of this $\$ 27,000$ was over and above receipts, but the institution was so 
far advanced that it would force itself through ; and the new legislature seemed well disposed. The date of the serpentine walls is determined also, but no word of their source is vouchsafed.

With the ten pavilions and the six hotels finished "the academic village," as proposed, was an accomplished fact, except for the central building which was to contain the library and rooms for public examinations, etc. Mr. Jefferson's was the guiding hand. He insisted on "regular architecture" and work well executed, whatever the cost. Sometimes his colleagues interposed with suggestions, which he heard with benignant patience, and disregarded with fortunate wisdom, in so far as exteriors were concerned. They could do pretty much what they pleased with the interiors. The legislators complained of the ornamental character of his structures because less ornate ones would be cheaper, but the fear of adverse votes on appropriations for the institution had no effect on Mr. Jefferson. He said nothing at the time but pressed on, his purpose steady. Afterward he did say something. "Had we built a barn for a college and log huts for accommodations, should we ever have had the assurance to propose to an European professor of the first order of science?"

As much as he was attached to popular education and as firmly as he believed the establishment of his University necessary to the safety of the State and the happiness of the people, he would have abandoned it all if he had been required to disregard the arts in its forming. He was its architect. What other man in the United States at that time was competent to supply what his taste demanded?

${ }^{3}$ Jefferson to Gallatin, October 29, 1822. 
"Mr. Jefferson," wrote the Marquis de Chastellux in describing Monticello, "is the first American who has consulted the fine arts to know how he should shelter himself from the weather."

Nor was his architectural hobby a result of his sojourn in France. A decade before he crossed the ocean he had planned the house at Monticello and it was well on the way to completion-an attractive example of the Italian style, and superior to all other houses in America at that time in point of taste and convenience. ${ }^{4}$ But he profited in Europe by his opportunities to see the best examples of architectural art. "Here I am, madam," he wrote at Nimes, where Roman remains were many, to the Comtesse de Tesse, "gazing whole hours at the Maison Quarree, like a lover at his mistress. The stocking weavers and silk spinners around it consider me as a hypochondriac Englishman about to write with a pistol the last chapter of his history. This is the second time I have been in love since I left Paris. The first was with a Diana at the Chateau de Laye-Epinaye, in Beaujolais, a delicious morsel of sculpture by $\mathrm{M}$ : A. Soldtz. This, you will say, was in rule, to fall in love with a female beauty-but, with a house! It is out of all precedent! No, madam, it is not without precedent in my own history. While in Paris I was violently smitten with the Hotel de Salm, and used to go to the Tuilleries almost daily to look at it."

Convinced, as he wrote Mr. Madison long before the University was under construction, that his countrymen ought to avail themselves of every occasion when public buildings were to be erected of presenting models for study and imitation, he put his

- Duc de la Rochefoucauld-Liancourt. 
theories into effect in planning the pavilions. Andrea Palladio, whose imitative genius put in reach of lovers of architectural art some of the finest examples of antiquity, proved a source of bountiful supply. During his student life he made many drawings of the buildings of ancient Rome, and some of these survive in I quattro libri dell' Architettura, which reached England through the edition of Inigo Jones, but came to Mr. Jefferson through Leone's edition published in London in I72I. Harmony, accuracy of detail, and faithfulness to ancient examples were leading features of Palladio's work, and those characteristics made powerful appeal to Mr. Jefferson. The Lombard paid little attention to the consideration of utility and convenience; and some at least of the dwellers in the temples and theatres on the Lawn of the University have thought Mr. Jefferson equally indifferent to those qualities. "It cannot be denied that the great architect cared too much for the beauty of the exterior and rather too little for the comfort within. Considerations of judicious economy might excuse the single stack of chimneys in the centre of the professors' houses, around which the rooms had to arrange themselves as well as they could, and his quaint hope that the future dons would, like the fellows of English Universities, remain unmarried forever, might explain the large lecture halls which received the visitor as he entered the front door, without vestibule or porch. But that even closets were forbidden, seemed to be a peculiar hardship, and when Mr. Jefferson once opened the door of the only one in the University, and utterly unprepared for such a solecism, walked into it instead of out of the pavilion, 
the anecdote was received with universal and not undeserved hilarity."

The plates in Palladio's great work were to him satisfying examples of classic architecture. They showed him the Temple of Fortuna Virilis, which still stands between the Ponte Rotto and the temple of Vesta; the theatre of Marcellus which survives in a fragment of two stories and is crowded by the Palezzo Orsini, and the baths of Diocletian, whose remains are pretty sure to catch the eye of one who enters Rome by the Piazza di Termini. The exterior of the baths of Diocletian, the temple of Fortuna Virilis and the theatre of Marcellus fixed his purpose. The schools of his University-for each pavilion was to have a school-these homes of his professors-should present to the world all the charm of their Doric, Ionic or Corinthian beauty; not perhaps just as they appeared in Palladio, but, if changed, with their classic purity surviving in unaba ted loveliness. The old gentleman and Cornelia Randolph, his granddaughter, with infinite care, adapted bath and temple and theatre to the purposes of art and utility, and so skilfully and accurately in every detail that, with Mr. Jefferson's specifications written on the back of each drawing, no further plans were necessary for the builders.

It was these structures that the proctor reported as nearly completed in October, 1822. With their connecting dormitories and Tuscan arcades they presented, even in the rough state of their surroundings, a dignity and beauty which favorably impressed all beholders. George Ticknor of Harvard, who had had more than one Wanderjahr in Europe, assured his friend Prescott, the historian, that the University of Virginia was "a mass of buildings 
more beautiful than anything architectural in New England and more appropriate to an university than can be found, perhaps, in the world."

Perhaps the first almost perfect objects of art brought to this country from Italy were the capitals of Carrara marble for the pavilion porticoes. These importations subjected the old rector to much ill-natured criticism. The fact that he had employed Italian artists in the vain hope that capitals could be carved from native material did not soften the aspersions. $\mathrm{He}$ then brought marble from Carrara from which some of the needed capitals were carved by the brothers Michael and Giacoma Raggi. This proved more expensive than to have the capitals carved in Italy, and the Raggi brothers returned to Leghorn. ${ }^{5}$

Under date of April 16, I821, Jefferson wrote to Thomas Appleton, United States consul at Leghorn: "We shall have occasion the next year for ten Corinthian capitals for columns of 32 I. diminished diam. and 8 do. half capitals of the same diam. for pilasters of 30 minutes projection from the wall, to be copied from those of the Rotunda, or Pantheon, of Rome, as represented in Palladio. Be so good as to inform me what will be their exact cost."

This is the first indication that Mr. Jefferson had decided upon the Pantheon as the model for his chief University structure, although there are reasons for believing that he had chosen as early as the first delineation of the plan of the academic village (I8I7). One of his drawings shows the parallel

"An illustration of Mr. Jefferson's attention to details is afforded by his "Specifications of the Corinthian and Ionic capitals wanting for the University," written on a single sheet of thin paper and preserved at the University. 
lines along which the pavilions and connecting dormitories were to be placed. These parallels arc united by a curve at the noithern end of the Lawn which is enclosed in these lines, and on the inside of the arc is a complete circle marking the place at which the Rotunda now stanis. Elsewhere the location of buildings is indicated by figures of straight sides. The adaptation and drawings for the Rotunda were, probably, already in existence, and yet it is known that his drawings and specification for the pavilions were in some cases made as needed, and it may be that the details of the plans, although well thought out, were not committed to paper until the workmen were ready.

To this day the tourist visiting the Eternal City turns out of the Corso or the Piazza Navona to see the Pantheon, the noblest surviving example in Rome of antique art; and three hundred years ago the student from Vincenza lingered often and long, and with all an artist's enthusiasm, over its many beauties. It was approached by a portico of I IO feet wide and 44 deep, sustained by sixteen columns of fine oriental granite 36 feet high with Corinthian capitals. The chief structure is a cylinder surmounted by a dome cast of concrete. Hawthorne delighted to watch the varying lights of a Roman afternoon displayed on the clouds drifting over the large circular opening in the dome, the sole source of light, which admitted the rain as impartially as the sunshine. The interior, once ornamented with rich oriental marbles, has a diameter of 143 feet. Mr. Jefferson's adaptation is 77 feet, "being half that of the Pantheon and consequently one fourth in area, and one eighth its volume." The State of Virginia could not afford the rich materials at the 
command of Agrippa-massive bronze plate for the covering, or monoliths for the columns, or oriental marbles to face the interior walls; and yet, "in the opinion of competent judges who have critically examined the ancient and the modern structures, $\mathrm{Mr}$. Jefferson's building was in several respects superior to the original. The latter was approached by five steps, Mr. Jefferson's fourteen, giving an elevation to the handsome portico which contributed greatly to its imposing beauty. The Roman portico is Io8 feet by 42 , with sixteen columns 39 feet high, and divided into three colonnades. Mr. Jefferson's portico is 50 feet by 28 feet 6 inches, with ten columns 28 feet 6 inches high, and its floor space is undivided, giving it a much lighter and more airy, as well as relatively loftier, aspect. Lastly, Mr. Jefferson raised the floor of the portico and thus increased the height of the cylindrical drum until it was equal to its diameter. The massive and ponderous original must always have seemed from without somewhat dumpy. Within, the glorious vault, typifying the dome of heaven, the home of all the gods, naturally made such an impression impossible. Mr. Jefferson was obliged, by the proposed uses of the building, to divide it into three stories, the upper one representing the single apartment of the Pantheon. That circular room has been said by many travelers to be the most beautiful and well proportioned one they ever saw. It was undeniably a handsome and unique apartment, and well justified the pride of its author and the admiration it has had from the long line of students."

It is to be regretted that Mr. Jefferson did not live to see the Rotunda finished. Its noble portico

${ }^{-}$Professor Francis H. Smith. 
had not been begun, no vestige of the structure which afterward united it with the east and west sides of the Lawn had appeared, and it stood a simple unadorned brick cylinder surmounted by a hemisphere or dome. But the way had been prepared for the completion of the structure, the plans were in hand, every problem that could trouble the builder had been foreseen and solved, even to the number of bricks necessary for each column. The capitals had been ordered through Consul Appleton and arrangements made to pay for them on delivery. When Mr. Jefferson died on the 4 th of July, I826, he left no work unfinished, and what an immense amount of it, all good, had he done in his long and useful life!

The Pantheon has had its vicissitudes, and its copy in Virginia has not escaped disfigurements. Some authority imposed a belfry upon it at one time. A queer circular structure arose from the central light of the dome like a huge wen on a bald cranium, and if the testimony of lithographs is accepted a weather vane once surmounted it! But perhaps none of these excrescences were so offensive and certainly not a source of so much danger to the Rotunda as the annex, a large oblong five-story erection, roo feet long and 54 broad, which occupied the space within the stone ramparts on the north side. This building stood 30 feet from the Rotunda and was joined to it, at the level of the floor of the portico, by a pillared porch, and its northern end was finished with a Corinthian portico of some dignity. It was constructed to relieve the crowded condition of the lecture-rooms in the Rotunda and to afford a hall for the public assemblages. The commencement exercises-from the first of them in 
July, I829-were held in the library, and the attendance was often so large as to excite fear that the floor would give way. The annex was begun in I85 I-in spite of the protest of Colonel Thomas J. Randolph, who said it would be the cause of the destruction of the Rotunda, as it was! - and was ready for the commencement festivities of 1853 . Its public hall-nearly roo feet long and 50 wide-with ample galleries was not wanting in a severe dignity, which was enhanced by Balze's fine copy of Raphael's school of Athens from the walls of the Sala de Segnatura in the Vatican.

No defense, except the doubtful one of utility, could be made of the annex, as viewed from the outside, and especially as seen in its disfiguring proximity to the Rotunda, but many of "the old boys" of thirty years ago remember the splendid spectacle afforded on commencement evenings when the Rotunda and the Public Hall were a blaze of light, and it seemed impossible that any avenue could be so noble and dazzling as the one from the portico through the Rotunda and the connecting porch into the great hall, where the whole view ended in the rostrum and Raphael's assembled philosophers. Even the architectural accessories of the great painting - the portico, columns, and high-arched portals - seemed details of the Public Hall itself. The hall's acoustics were not good, perhaps, but a thousand young men and women filling the floor and galleries-undisturbed by poor acoustics!-a dozen ushers rushing about with gay batons until they trouped their colors over the aisle in honor of the faculty, board, orators and distinguished guests, in stately progress to the rostrum-made a picture full 
of color and movement, and altogether good to look upon.

Daniel H. London of Richmond, while in Rome in I850, saw Raphael's painting and was impressed with its splendor. On his return he suggested to Thomas H. Ellis, then of Richmond, that a copy ought to be at the University. Colonel Ellis requested John S. Caskie, Socrates Maupin, afterwards professor at the University, Benjamin B. Minor, and John R. Thompson, all graduates of the institution, to act with him as a committee. They consented, and the committee published a circular appealing to alumni only for contributions. The following spring $\mathrm{Mr}$. London, then departing for Europe, was requested to order a copy of the painting to be made by Signor Mazzolini of Rome, and to secure him from loss three members of the committee-Colonel Ellis, Judge Caskie, and Mr. Thompson-each accepted an order for $\$ 500$. Mazzolini was not available at the time and after some delay preliminary arrangements were made with Monsieur Paul Balze, who had spent twelve years copying paintings by Raphael for the French Government, and who had already made two copies of the School of Athens. This choice of artists was approved by University of Virginia men then in Paris, among them John L. Peyton, John R. Page, John G. Brodnax, A. Robert McKee, and Edward G. Higginbotham. In the meantime, William F. Wickham of Hanover saw Mazzolini in Rome and received from him a proposition for making the copy. This was referred to the Society of Alumni and declined by it at its meeting in June, 1852. At the same time a committee was appointed to confer with the alumni and urge them to unite in carrying 
out the design of procuring a copy of the picture for the University. The members of this committee were Thomas H. Ellis, John R. Thompson, Benjamin B. Minor, John S. Caskie, and Nathaniel H. Massie, and they made earnest efforts to accomplish their mission, but with little success at first. William A. Pratt of Richmond, in the spring of 1854 , entered into an agreement with the committee by which he undertook to procure a copy of the painting, and some months later became the financial agent of the committee. In two years he had more than half enough money for his purpose; in June, I856, he went to Paris, and on the 7 th of July was in possession of the canvas. By the agreement with Mr. Pratt the copy was to be approved by competent judges in the French capital, and the committee requested the services of Horace Vernet, the most eminent French artist then living. $\mathrm{He}$ reported that no one had reproduced the masterpieces of Raphael so well as Balze, and that "this last copy was an encouraging pledge for the art in the event the original was lost."

The picture was exhibited at the Royal Polytechnic Institute in London. The leading Academicians of the day, among them Sir Charles Eastlake, president of the Academy, and the pre-Raphaelite leader William M. Rossetti, testified to its fidelity, and the London press joined in a chorus of praise. Mr. Pratt delivered illustrated lectures at all views, and at least one of them, "Athenian Philosophy I1lustrated in the Persons of Her Sages," was in verse, displaying, according to the London Herald, "poetical beauties of no ordinary class."

The picture was first exhibited in this country at 13 
Romney, Hampshire County, Virginia, where Mr. Pratt's family had spent the term of his absence in Europe; later in Winchester, Wheeling, Warrenton, Lexington, Capon Springs, at the Old Market in Richmond, and in Library Hall, Petersburg, and reached the University in February, 1857. The Board of Visitors appropriated $\$ 700$ to prepare suitably for its hanging in the Public Hall of the Annex. It was opened to the public on Jefferson's birthday of that year, and the address was by Major Preston of the Virginia Military Institute. Mr. Pratt was present, and in response to repeated calls described the painting. The University Magazine found his remarks "teeming with the spirit of classic poetry." No doubt his description was the lecture in verse which won the praise of the London Herald. $^{7}$

For more than thirty-eight years this painting adorned the public hall, and, after the Rotunda, was the object most sought out by tourists. Every session for many years Professor Noah K. Davis of the school of moral philosophy delivered an instructive and intensely interesting lecture on Raphael, his work on this fresco, and on the most prominent of its fifty-eight life-size figures. It is to be regretted that other masterpieces have not followed Raphael's.

The Jeffersonian group of buildings plainly indicated the order for all subsequent structures, but absolute disregard of congruity and harmony characterized every building erected for nearly seventy years after the founder's death. The climax was reached in half a century, in the Lewis Brooks Mu-

${ }^{7}$ A very satisfactory account of the acquisition of Balze's copy of the School of Athens appeared in the Southern Literary Messenger, XXIII, 458. 
seum, a structure of four stories, within a stone's throw of the Rotunda, on the northeast side. Professor Henry A. Ward of Rochester, New York, in I 876 announced to a member of the faculty of the University that an admirer of $\mathrm{Mr}$. Jefferson wished to establish at the University an extensive museum of natural history, provided other friends would contribute $\$ 12,000$ to furnish the necessary cases, etc. The Miller Board contributed \$10,00o and Professor William Barton Rogers and others the remainder. Mr. Brooks's gift amounted to \$50,000, and by his request $\$ 25,000$ of it was devoted to the material for the cabinet of natural history and $\$ 25,000$ to the erection of a suitable building. $\mathrm{Mr}$. Brooks afterwards increased his contribution by nearly $\$ 20,000$. The building was completed in July, i887.

The structure is of brick in the Rennaisance order, and rather too elaborately ornamented with granite trimmings and the carved heads of various animals. In the granite are graven the names of Cuvier, De Candolle, Audubon, Huxley, Pliny, and others. The architect arrived at the University with his drawings made, and all efforts to convince him of their unsuitableness to the surroundings were ineffective. Although an offensive intruder, viewed architecturally, the building is the repositorium of valuable natural history collections, which constitute an indispensable aid to scientific investigation and instruction. The geological collectons are on the floor of the lower or chief hall and the mineralogical specimens in the galleries around this room. The main floor of the upper hall is taken up with the zoological exhibit and the botanical specimens are in an adjoining room. The 
lectures in the school of natural history are delivered in this building.

After the annex to the Rotunda perhaps the first buildings added to the Jeffersonian groups were the dormitories now known as Monroe Hill. This eminence took its name from a building which President Monroe once occupied and which was afterward the residence of the first proctor, Arthur S. Brockenbrough. Later it was considerably enlarged, and it is now a professor's house. Monroe's office was in a small building west of his residence.

The building known as the parsonage at the southern end of Dawson's Row was erected in I854-5 as a residence for the chaplain. As early as I85I the Visitors were requested to permit the building of a home for the chaplain on lands belonging to the University. The following year Colonel Thomas Jefferson Randolph, from a special committee to whom the board had referred the matter, made a lengthy report which authorized the professors to open a subscription for donations to be received by the Visitors in trust for the University for the erection of such houses as might be necesssary for the religious worship of the professors and students on such sites on the grounds of the University as the executive committee might approve. It was explicitly declared that all such buildings should belong to the University and be at all times under the control of the Visitors. The money was soon contributed. A year later ( $1855^{-6}$ ) the building at the entrance of the University was erected out of the funds contributed for the purpose by Gen. John H. Cocke and others interested in the movement for teetotalism. The Sons of Temperance for many years, and the Friends of 
Temperance afterward, held their meetings on the second floor. For this reason the building was called Temperance Hall. It is now more generally known as the post-office.

In 1859 there was a further extension of the dormitories by the erection of six two-story buildings on an arc running southward from Monroe Hill and eastward to the parsonage. Martin Dawson had devised a tract of land to the University and the proceeds of the sale of the landed possession paid for the buildings, thereafter known as Dawson's Row. The Infirmary was erected about this time, and between it and Dawson's Row arose a frame gymnasium and near by a wooden structure for Russian baths. Monsieur d'Alfonce, a Russian officer, was in charge of the gymnasium and responsible for the convenient innovation of a bath-house available to the students at large. The wooden structures were destroyed during the war.

In 1868 the Visitors authorized the building and equipment of a chemical laboratory on a small eminence west of the north end of West Range, and a residence for the professor was erected on Monroe Hill. Between the laboratory and West Range is "Med Hall," where many of the medical lectures are given. The present structure dates from I886, when the original building, one of the oldest erections at the University, was destroyed by fire.

The dormitories on Carr's Hill-it was first known as Brockenbrough's Hill-were constructed before the civil war. The ground was acquired from the late Mrs. Schele De Vere. The original building, occupied as a residence, was destroyed by fire some time before the University purchased the land. The name Carr's Hill was derived from a 
former owner. The mess hall is of recent origin. The small one-story detached house at the southwest point of the dormitory $\mathrm{L}$ was built by Judge Field of Culpeper for his son William G. Field, who was a student when the war began. Young Field was a member of the student company "The Southern Guard," and was killed at Malvern Hill.

Perhaps the first astronomical building in America was erected on the site of the Leander McCormick Observatory, on the summit of Mount Jefferson, a mile southwest of the University. In I88I, Mr. McCormick, for whom the present observatory was named, gave $\$ 50,000$ to establish such a station, and William H. Vanderbilt added \$25,000. The observatory is a rotunda forty-five feet in diameter, and contains a Clark refractor of twentysix inches aperture. Adjoining are the computing rooms, in which are housed a working library, clock, chronograph, etc.

With the small building erected by Mr. Jefferson for an astronomical observatory which fell into decay - and the building, ${ }^{7}$ also small, erected to provide a home for the janitor, the eccentric Dr. Smith, added, the list of buildings belonging to the old order is probably complete. It is scarcely saying too much to aver that not one of them harmonized fully, and not many of them even remotely, with the styles of architecture that give the original buildings the quality of beauty united to dignity. There was, evidently, nobody to take up Mr. Jefferson's propaganda for the recognition of art in building. The structures belonging to the later period, which be-

\footnotetext{
Removed to clear the ground for the residence of the bursar.
} 
gan with the restoration following the great fire, have been raised on plans provided by architects whose souls were susceptible and yielded to the transmitted charm of the masters. 


\section{CHAPTER XVI}

\section{MILITARY ORGANIZATIONS-THE CIVIL WAR}

\section{Early Military Spirit-VolunteEer Company-Disbanded FOR INSUBORDINATION-"REBEL" ENTHUSIASM AMONG THE Students-First Fiag Raised and First BloOd SHED-Student CoMpanies Formed-SOUTHERN GUARD -SONS OF LIBERTY- "Boyish RUSH TO DUTY"-HARPER'S FERRY-FACULTY AND THE WAR-SHERIDAN'S RAID.}

Very early in the history of the University students who cared for that sort of thing were afforded the opportunity for military drilling. William Matthews was probably the first drill-master, for he was engaged in 1826 , and Captain Partridge the next. The services of the latter ended in the spring of 1833 , because the riot of November 12 of that year did not contribute to popularize military enterprises with the professors. In I83 I the first volunteer company was organized, and annually thereafter until 1833, when the faculty ruthlessly disbanded it on account of pronounced insubordination, and no move was made to reorganize it until I846. Then forty-two students petitioned for permission. They set forth that the evolutions were a harmless amusement, and healthful, and pledged themselves to preserve good order, and not to load their muskets during the session or to use them improperly. Another motive, it was said, was a desire to offer their services as volunteers, at the close of the session, in the war with Mexico then in progress. But the faculty, while awarding all credit to the spirit which actuated the students, felt that neither the general policy of the University nor the 
welfare of the students would be promoted by the formation of a company. Sixty years after, it looks as if the petition could have been granted wisely, with proper safeguards, and an outlet afforded for the superabundant energies of the University boys. Athletics were not then the fortunate factor in college and university life they have since become, and quoits and marbles, played under the arcades which once occupied the spaces now covered by the terrace rooms that connect the Rotunda with the East and West Lawns, were about the only athletic resorts of active young men. Marbles and quoits do not, at their best, use up much energy, and it is conceivable that they could be disdained as amusements-as frequently they were,--for the more exciting sport of riots.

When South Carolina seceded from the union of States, the important step was not taken a moment in advance of the sentiment among the students. They were ready for it, and full of "rebel" enthusiasm. The sentiment for disunion was not due to the teaching of the professors, for not more than one of them ever uttered or intimated an opinion in the presence of a student, although all but one entertained the prevailing convictions. Perhaps Professor Holcombe's lectures on constitutional and international law could be justly credited with an occasional echo of the Southern contention which had become somewhat noisy. Certainly many students "cut" in the academic schools and filled his class-room to overflowing. They heard eloquent discourses which, if they did not excite, certainly did not check their secession tendencies.

A picture of those times would be incomplete without some touch of the humor and fun which 
students contrived then, and still contrive, to get out of occasions when the issue involves tremendous consequences. The late Dr. R. Channing Moore Page related an escapade which is both amusing and illustrative:

"One fine afternoon during the last week in February, I86I, two students from Carr's Hill took a walk together down town. One of them was the writer of this article, the other was Randolph $\mathrm{H}$. McKim, of Baltimore. Said McKim on the way down, 'Those fellows over on Dawson's Row, so I learn from some ladies, are next Saturday going to hoist a very expensive secession flag, made of silk, and we must somehow get ahead of them.' What fun to take all the wind out of their fine silk flag by putting up a cheap one first.

" 'What revenge, too, on those girls for not taking me in to their confidence,' said McKim, laughingly. But there was no time to be lost. It must be done tonight or never. But how?

"On the south side of Main street in Charlottesville we saw some women working sewing machines. To buy some cheap cambric of requisite color from a neighboring store and have it sewed together, stars and all, was short work. We then went into a hardware store (Massie's, if I remember rightly) and bought a large-sized gimlet and a key-hole saw. 'What's that for?' said McKim. The writer recalled to his mind that some months previously we had tried to get up to the top of the Rotunda for another purpose by means of trying to batter down the back door with a large pine log, but ignominiously failed. Now, however, we would saw out a panel and get through all right. Regular burglary! We now called by a negro carpenter's shop close by 
the railroad and had a flagstaff made. It was twelve feet long and finely proportioned. The negro, Isaac Sampson, was directed to bring the staff up to Carr's Hill by the back way at I I o'clock that night precisely.

"But we must have more men for such a grand undertaking-who should they be? Here are the names of the whole party in alphabetical order: George Bedinger, James M. Garnett, John Latane, Randolph H. McKim, R. C. M. Page, William Wirt Robinson and William N. Wellford. ${ }^{1}$ The negro was true to his word and on time with the flagstaff. It was quickly and without notice taken into McKim's room. The flag was securely fastened to it, and at I o'clock A. M., February 26, I86I, we started out to plant that flag on top of the Rotunda. Everything succeeded with mathematical precision. The panel in the enormous back door of the Rotunda was soon removed. Bedinger was the first man through. We are now in the Library, but how to get through that door leading out on the Rotunda near the bell? Butt it down, for it was too thick and full of nails to saw through. Forming in line we stood back and took a running start at the door, taking it by turns who should act as buffer. It was not long before the door, frame and all went down with a crash. Then out to the lightning-rod. The wind was high and it was now bitter cold. Dangerous work climbing over that dome by a slender lightning-rod! But we did it. The cupola with the arrow surmounting it, but since removed, was reached and the pole securely lashed to the lightning-rod. The flag was given full swing and went to the breeze in splendid style. Now to get back

${ }^{1}$ Not Wellford, but P. Lewis Burwell. 
without being caught! Soon it would be daylight. In my haste down the rod the sharp pointed saw stuck me in the right cheek so that for a time it bled profusely. The first flag had been raised and the first blood shed! Just as we passed by the bell it thundered out 4 o'clock. Upon looking down I noticed a negro putting out the gas lights. It was a beautiful star-light night; and though not yet daybreak the great flag floating from the top of the Rotunda was distinctly visible. 'Hush-sh-sh! we will be found out, keep quiet, boys.' 'Hi! whar dat flag kum from?' soliloquized the darky out loud. 'I ain't nuvver see dat befo'. Hi! dese certun'y is cu'yous times.' No sooner had the negro got well out of the way, however, than we all got back to our rooms as soon as possible.

"The news spread like wildfire. So great was the excitement that but little college work could be done that day. One of the first things to find out was what the professors thought of it, for with the exception of Mr. Holcombe in the Law School all had been very quiet and conservative in their views. But now the time had come when they must take that flag down or let it stand-which would they do? 'Old Bled' called it his flag. Dr. Cabell treated it as a schoolboy's joke; which it really was, as already stated, in order to get ahead of Dawson's Row. But there was a military-looking, bred-in-thebone Union man named Minor-John B. Minorprofessor of law, and order, too, for that matter. Perhaps, reader, you have heard of him, yes, and seen him, too. Well, now here was a man whose opinion must be had at all costs, but how to get it? We watched for him when he came out of his house to go to lecture, for nothing could induce him to 
come out to look at that flag. But on his way to lecture he could not help himself. 'Oh! Mr. Minor, do look at that beautiful flag!' The military-looking Union man looked up once, and as he went off he was heard saying to himself :

\section{"Flag of my country, can it be} That in thy place a rag I see."

At least that is what the boys said he said. What he really did say I believe I know but I am not going to tell it. Certain it is that if caught we would have at once been expelled. What became of the flag?"

One of the participants in the escapade wrote, many years after, ${ }^{2}$ that as the State had not yet seceded the chairman of the faculty courteously announced that if the gentlemen who erected the flag would take it down nothing more would be said about it. They would have done so but were anticipated by other students, and when the flag was brought to the Rotunda steps it served as the text for several "red hot" secession speeches after which it was taken to Carr's Hill by the owners, and there waved on top of one of the buildings until Confederate flags were no rarity at the University.

The faculty no longer refused permission for the organization of a military company. The University Magazine of February, 1861, affords a glimpse of the warlike preparations that engrossed the energies of the students to such an extent that they had no time for collisions with college authority: "The complication of political affairs has thickened around us, the influence of the great national

${ }^{2}$ James Mercer Garnett, in his fine sketch of the University, p. I7I. 
agitation has permeated our sacred bounds, and beneath the frown of threatening emergencies, the military spirit has become irrepressible. The consequence is we now have in our midst two companies of student-soldiery, officered, armed, and uniformed and already able, we modestly venture, to stand 'all in a row,' with 'toes out and eyes front.' Every afternoon the Lawn presents quite a busy appearance. Numbers of spectators assembie to witness the skill of the animated automata in going through the manual-performing evolutions promptly at the word of command. And similar scenes enliven the quiet shades of 'The Hill.'

"These companies have adopted as their names The Sons of Liberty and The Southern Guard. The period of their formation will be a brilliant era in the history of the University. We heartily bid them God-speed, and confidently predict that, should their country ever call them into service, they will prove themselves worthy of the proud and patriotic titles they have selected."

The martial fever spread even to the professorsnot merely to Holcombe, who was the idol of the young sons of Mars, but probably to all but Professor Minor, who was a strong "Union man." "The faculty formed a smaller company-an awkward squad indeed-which wisely for a time performed its evolutions in a private room, but later on grew bold enough to appear on the Lawn to the boundless amusement of the better drilled students. Armed with old-fashioned flint-lock muskets of antiquated pattern, gotten from a revolutionary residue long kept in the State Arsenal at Lexington, which they held at all inclinations to the vertical, they presented the most wonderful variety of movements for 
each word of command. It was too much for human composure to see the pairs of optics converged upon Mr. Schele when he gave the sharp, convulsive command, 'Attention, squat!' as it sounded to us. Fortunately for the Confederacy, whose collapse would, doubtless, otherwise have been hastened, this squad calculated to be so formidable to its foes was never called to the field." 3

The student companies were organized immemediately after the Presidential election of November, 1860. The first was the Southern Guard. Its officers were:

Ed. S. Hutter, Captain. L. D. Roane, Color SerGeorge Ross, First Lieu- geant.

tenant. William Pegram, SecFrank Carter, S e c ond ond Sergeant.

Lieutenant.

R. E. Lee, Jr., First CorJohn M. Payne, Third Lieutenant.

P. Lewis Burwell, First ond Corporal. Sergeant.

R. Corbin Wellford, Third Corporal.

The other members of the company, as far as Captain Hutter could recall them thirty years after the organization, were :

Baldwin, Robert J.

Barbour, Phil P.

Barton, David R.

Chapman, William $\mathrm{H}$.

Blankenship, R. E. J.

Coleman, Charles L.

Boyd, E. Holmes.

Brown, William.

Chapman, G. B.

Davidson, Charles A.

DeClouet, Paul L.

Doak, A. V.

Elliott, Percival.

Fairfax, Randolph.

${ }^{3}$ Professor Francis H. Smith. 
Falligant, Robert.

Field, William G.

Fleming, Mal. N.

French, J. Compton.

Garnett, James M.

Gildersleeve, John R.

Goggin, William L.

Grivot, W. P.

Grogan, K.

Harris, J. W.

Heath, A. C.

Hinton, D. A.

Howard, James McH.

Hunter, R. M. T., Jr.

Ingle, Edward $\mathrm{H}$.

Jennings, R. B.

Kinsey, R. W.

Latane, John.

Lewis, A. J.

Lewis, John $\mathrm{H}$.

Mackall, T. B.

Maury, J. H.

McCabe, W. Gordon.

McKim, Randolph $\mathrm{H}$.

McKim, Robert.

Michie, H: Clay.

Micou, W. B.

Minor, C. N. B.

Minor, W. W.

Moncure, W. P.
Murdock, R.

Neblett, N. M.

Norwood, J. J.

Norwood, Thos. H.

Page, R. Channing M.

Pegram, William J.

Pendleton, A. S.

Pulliam, Samuel H.

Randolph, B. M.

Randolph, W. L.

Rives, C. M.

Rives, G. Tucker.

Roane, L. D.

Robinson, W. W.

Ross, William A.

Schaumburg, Wright C.

Singleton, Richard R.

Smith, W. G.

Stephenson, Lloyd B.

Tayloe, Lomax.

Taylor, Bernard M.

Trueheart, Charles W.

Voss, F.

Walke, I. T.

Weir, Walter.

Wellford, R. C.

Wellford, William $\mathrm{N}$.

Worthington, W. N.

Wrenn, Fenton E.

Wrenn, Virginius.

Munford, Charles Ellis. Wright, T. R. B.

Munnikhuysen, Howard. Wynn, William G.

The young soldiers drilled energetically until the middle of April, I86I. Even the celebration of $\mathrm{Mr}$. 
Jefferson's birthday that year took on a military character. In the battalion drill arranged for that event the following companies took part: The Albemarle Rifles of Charlottesville, Captain R. T. W. Duke, afterwards colonel of the Forty-sixth Virginia Regiment; the Monticello Guards of Charlottesville, Captain William Barton Mallory; the Southern Guard, Captain Edward S. Hutter of Lynchburg, afterwards a major in the Confederate service, and the Sons of Liberty, Captain James M. Tosh of Roanoke.

Captain Hutter was requested by the commissioned officers to take command that day of the battalion, which consisted of some four hundred men, handsomely uniformed and well equipped. The drill began at 4 o'clock on April I3, I86r, and was witnessed by a great concourse of people on the Lawn. While the troop was drawn up in line a messenger handed a telegram to Captain Hutter, who read it. It was dated that day at Richmond, and was signed by O. Jennings Wise- "Fort Sumter has surrendered and the Palmetto flag now floats over its walls." A mighty shout arose from the multitude. ${ }^{4}$

Mr. Frank S. Robertson, the orderly sergeant of the other company, "The Sons of Liberty," tells the story of its organization, and gives a vivid picture of the stirring times at the University immediately preceding the secession of the State. "The ranks were soon full, officers elected, and the Lawn made lively by the laughable movements of the awkward squad.

"The captain of the "Southern Guard," Major Hutter, contributed interesting reminiscences to "Corks and Curls" for 1889-90, to which I am indebted. 
The officers were in the main chosen from the former graduates of the V. M. I. Uniforms were ordered from Baltimore. 'The Sons of Liberty' (named by Professor Holcombe) wore red shirts trimmed with black velvet and well-bespangled with brass buttons, black doeskin trousers, dark blue caps, and white cross-belts with huge brass buckles. The other company, the 'Southern Guard,' was distinguished by blue shirts and light blue caps.

"Arms were secured from Richmond, and consisted of very ancient flint-lock muskets (minus the flints), cartridge boxes (but no cartridges), and bayonet scabbards! We drilled by Scott's Manual, and the noise made by the manipulation of the long iron ram-rods was in itself enough to frighten the souls of our adversaries, and possibly upon this we mainly relied. We bore no banners and we had no brass bands to stir our souls, but marched to the monotonous 'Hep, hep, hep!' of our officers, and yet I have never seen troops look more trim and soldierly. The companies numbered about sixty-five or seventy each, rank and file, and were commanded respectively by Captain William Tabb of Amelia County and Captain Ned Hutter of Lynchburg.

"On the I6th of April, I86I, a rumor went the rounds that 'something was up and we were to be in it.' Fort Monroe was thought to be the objective point, and visions of marching through Richmond filled our hearts with joy. Late in the evening orders were given to assemble on the Lawn, and things began to hum with excitement. Shouts resounded on all sides, hurried good-bys were spoken, red and blue flashes could be seen everywhere. There were students in both companies who, for various rea- 
sons, were unable to go, and substitutes were quickly donning the proffered uniforms and filling the vacant places in the ranks.

"Our Captain (Tabb) was too sick to leave and a hasty reorganization was necessary. In the various changes I became orderly sergeant of the company, and to this is due my having the company-roll in my possession. It contains, of course, only the names of those who went to Harper's Ferry and does not purport to be a roll of the original members.

"About dark the battalion marched to Charlottesville, where we found the 'Monticello Guards' of that town under arms awaiting a train from Staunton on which came the 'West Augusta Guards' and perhaps other troops-I do not remember. We formed a battalion with the Charlottesville company and were commanded by Major Carr."

"As soon as the train arrived we were loaded in box cars, and were soon off for the war-sans rations, blankets, overcoats, haversacks, canteens and cartridges, with not even a candle to break the total darkness-two carloads of unprepared but unquenchable enthusiasm. Was there one of us that did not during the stern trials that so soon came to test us recall with a smile-perhaps a tear-that first boyish rush to duty?

"At Gordonsville we were switched off nolens volens, from our much wished for march through Richmond, and landed about daybreak at Strasburg, with orders to march on by rock turnpike to Winchester, eighteen long miles away. The good peo-

"As we stood drawn up at the station awaiting the train that was to bear us away to 'fields of glory,' Professor Holcombe read to us the official announcement of the secession of the State."-McCabe's Virginia Schools Before and After the Revolution, page 60 . 
ple of Strasburg gave us of their bread and meatthe first meal of the many that they spread for the hungry 'Rebs' - and we tackled the sharp macadam with our tight boots. About dark we reached Winchester, many of us limping, and some of us entirely soleless. A band suddenly appeared in our front and we marched down the streets to the cheery but somewhat inappropriate tune of 'Yankee Doodle,' while cries of 'Hurrah for the Union!' inhospitably greeted our ears. Only that day, April I7, had the Ordinance of Secession been passed at Richmond, and the news had not then reached Winchester. As soon as we halted, our company was cut up into squads of ten and, piloted by sympathizing citizens, we went to their homes and cleared the larders. About midnight we were again loaded in box cars and armed with flints, which had just been distributed, but with no cartridges as yet, we resumed the 'forward' to Harper's Ferry, which we reached at daylight. The Federal garrison was burning the arsenal, and many thousand stands of arms at our approach, and quietly withdrawing without firing a shot. Our chief object, doubtless, was to secure those arms for the Confederacy, and we did capture great numbers that had been secreted by the citizens. In half an hour after taking possession we were fully equipped with the latest improved Springfields and ammunition and were at once sent out to search for arms or detailed on garrison duty.

"Our company was quartered in an old depot near the end of the railroad bridge, and fared badly, to say the least. And then, after a hard but bloodless campaign of ten days, and without the gratification of firing even a blank cartridge from our much admired new arms, we were ordered back to the Uni- 
versity and disbanded. This order from Governor Letcher was most complimentary, and I am sorry I cannot give the full text of it. He said, however, that 'there was too much talent to be risked in one body,' and this was the chief reason for the order. It is only proper to say that his opinion was justified later, as nearly all of these men became officers."

The following is the roll of officers and privates now in the possession of Mr. Robertson. The names marked thus $\left(^{*}\right)$ cannot be identified with certainty, as there are no initials to guide one in a search in the catalogues of the institution:

James Tosh, Captain.

Robert J. Washington, First Lieutenant.

- Hill, Second Lieutenant.*

W. Page McCarty, Third Lieutenant.

Frank S. Robertson, Orderly.

John P. Lynch, Second Sergeant.

A. B. Paris, Third Sergeant.

William F. Gardner, Fourth Sergeant.

William C. Day, Fifth Sergeant.

John B. Mordecai, First Corporal.

C. B. Vance, Second Corporal.

James McD. Carrington, Third Corporal.

Henry L. Hoover, Fourth Corporal.

\section{Privates.}

Anderson.*

Bacon, R. A.

Battle, C. L.

Beale, J. R.

Bedell, John D.

Bedinger, C. R.

Berkeley, Carter.
Berkeley, William R.

Briscoe, J. B.

Brockenbrough, Austin.

Bronaugh, F. L.

Brown.*

Buford, James W.

Chancey, C. A. 
Corprew.*

Couper, R. H!

Dew, B. F., Jr.

Drewry, James $\mathrm{H}$.

Ewing.*

Goffigon, John.

Hall.*

Harvie, C. I.

Henderson, L. A.

Holleyman, G. C.

Hunter, John, Jr.

Larew, Isaac $\mathrm{H}$.

Lauve, Alphonse.

Lee, Charles D.

Lee, Henry.

Moyler, J. Edward.

Nicholas, Robert C.

Payne, John M.

Pearce, Robert S.
Peck, J. Edward.

Pratt.*

Preston, John M.

Radford, William M.

Randolph, M. L.

Redwood, John T.

Richardson, Charles T.

Riddick.*

Smith.*

Swoope, F. M.

Thomas, J. Hanson, Jr.

Venable, Clement R.

White, James L.

Williams, C. U.

Williams, F. S.

Withers, Walter I.

Woodhouse, James G.

Wooldridge, A. B.

Wyatt, J. W.

In April or May, I86 I, a third student company was organized-Captain James Parran Crane of Great Mills, Maryland, afterwards lieutenant-colonel in the Confederate service, and William W. Old of Norfolk, later an aid-de-camp, lieutenant. This company was mustered into service in June or July of that year, and on the 4th of July left the University for Wise's Legion, which was operating in what is now West Virginia. These young soldiers became a part of Wise's second regiment in command of the Nicaraguan filibuster Colonel Henningsen and remained through the campaign in that section. When Wise was ordered to Roanoke Island the Secretary of War, Judah P. Benjamin, disbanded the company in order that the members 
might return home and join commands in their own States.

Nearly all the members of these companies became officers in the armies of the South and rendered a great service to the Confederacy. The University was almost without matriculates through the four succeeding years, the number falling from more than six hundred to about fifty. In 1863 the conscript officers made further levy on the institution, but it was found that only eighteen out of the forty were above eighteen, the minimum age limit of conscription.

The professors were requested to remain at their posts and continue the active.work of the University. Dr. James L. Cabell and Dr. John Staige Davis served the Confederacy as surgeons in the large hospital, on the site of the colored church near the Union depot in Charlottesville, known as Mudwall, and in the smaller one in Midway House, on the site of the present public school building. The first battle of Manassas, in the summer of 1861, was followed by the arrival at the University of many wounded Confederates and a few injured Federals who, in the absence of a hospital, were cared for impartially in the halls and dormitories of that institution. Professor Francis H. Smith, by appointment of President Davis, with Commodore Maury, formed a Committee of Weights and Measures, and Professor Socrates Maupin gave important assistance in the manufacture of explosives.

Professor Basil L. Gildersleeve went into service, but did not resign. He taught Greek during the session and spent his vacation in the field, and was grievously wounded in 1864 while serving on the staff of Gen. John B. Gordon. 
Two professors resigned. Alfred Taylor Bledsoe, then professor of mathematics, had been a classmate at West Point of President Davis, and was commissioned colonel by him, but before he could join his regiment he was detailed as Chief of the Bureau of War. In 1863 he went to England on an important mission for the Confederate Government.

Professor Lewis Minor Coleman raised, in his native county of Caroline, a light battery and was elected its captain. The Board of Visitors refused to let him resign, but kept the position open to him. He rose to a lieutenant colonelcy of artillery. The scholar won renown in many battles before the fatal field of Fredericksburg saw him mortally hurt by a fragment of the same shell that killed his pupil, Randolph Fairfax, who "looked more like a woman and acted more like a man than any soldier in the battery." 6

Life at the University during the years from I86r to 1865 was not unlike that throughout the South in the matter of privation and self-denial, borne without complaining. There were many rumors of threatened invasion accompanied by plundering, but no Northern soldiers, except the wounded from Manassas, came to the University until late in the war, and then the public property was absolutely, and private convenience reasonably protected, owing probably to the wise course pursued by the University under the guidance of Professor Minor.

When the rumor reached the University that Sheridan's army, which had been for some days between Winchester and Waynesboro, had routed

\footnotetext{
${ }^{6}$ McCabe's Virginia Schools Before and After the Revolution, page 62 .
} 
Early at the latter place, and was marching toward Charlottesville, the faculty deputed its chairman, Dr. Socrates Maupin, Colonel Thomas L. Preston, the rector, then residing within half a mile of the University, and Professor Minor, ut capiat Universitas nil detrimenti, by soliciting a guard, etc. $\mathrm{Mr}$. Minor's diary contains a vivid account of the raid and how he and his colleagues discharged their duty as representatives of the University at that critical time:

"Whilst engaged in my school-room (with wandering thoughts on the part of both teacher and pupils), Albert. tells me that a young gentleman wishes to see me at the door, where I find George $\mathrm{C}$ __ t to announce that our picket line has been driven in and that the enemy are about Dr. Stephens's [five miles away], and may be expected in an hour or two at farthest. Soon after, Dr. Maupin sent me word that the town authorities (the mayor [the late Captain C. L. Fowler] and some of the council) had come up and would join us in our proposed application for protection. Accordingly, between I and 2 o'clock we repaired to the grounds opposite Carr's Hill, just by the pool which in happier hours bore the name of 'the pellucid,' and there awaited the enemy's coming. Our town friends had already arrived and had displayed a flag of truce, and in a short time the enemy's scouts were visible at the old toll-gate approaching with extreme caution. Videttes were stationed on each commanding eminence near the road, and it was not until they reached the brook below the ice-pond that they advanced with confidence. The flag then became visible, and ten or fifteen men approached at a gallop with their pistols in rest, the residue of the 
column dragging its slow length through the mud. We announced to these men, who were accompanied by a dirty looking lieutenant, that no defense of Charlottesville was contemplated, that the town was evacuated, and that we requested protection for the University and town.

"They told us General Sheridan was in command, that General Custer led the van and would be on in a few moments; and then staying for no further question put spurs to their horses and rode as fast as the deep mud would permit toward town-we feared to plunder. In a few minutes a good-looking officer rode up, who announced himself as General Custer's adjutant-general, I believe, and upon our restating our wishes said a guard would be furnished the University and private property everywhere would be protected. Immediately after, General Custer passed in triumph with three of our battleflags displayed, when two members of his staff rode out of the line to repeat the assurance of protection to the University. The town gentlemen now hastened to Charlottesville, whither Dr. Maupin and I also resolved to go that the promise of a guard might not be forgotten. $* * *$ Upon returning we found one had been posted, which, however, was in a short time reduced to a single man. He remained all the afternoon at the corner opposite the Medical Hall, and was extremely serviceable and very courteous. About nightfall the provost marshal came to relieve him, and was about to leave us defenseless, but agreed with the man's consent that he might stay until the morning. I got a place for his horse and Mrs. C_- who had been occupying the house at the corner for some months, proposed that he should stay in their parlor. Between 9 and ro 
o'clock he and I made the circuit of the University, and then he went to sleep; but I proposed to remain up all night."

General Sheridan ${ }^{7}$ gives this account of this part of his raid: "The night of March 2, Custer camped at Brookfield, Devin remaining at Waynesboro. The former started for Charlottesville the next morning early, followed by Devin with but two brigades, Gibbs having been left behind to blow up the iron railroad bridge across South River. * * * I concluded to rest at Charlottesville for a couple of - days and recuperate a little, intending at the same time to destroy, with small parties, the railroad from that point to Lynchburg. Custer reached Charlottesville the $3 \mathrm{~d}$ in the afternoon and was met at the outskirts by a deputation of the citizens, headed by the mayor, who surrendered the town with mediaeval ceremony, formally handing over the keys of the public buildings and the University of Virginia."

Sheridan and his men left Charlottesville on Sunday morning, March 6, I865. Mr. Minor made this entry in his diary: "Scarcely had the rearguard disappeared before our eyes were greeted by the sight of the soiled but loved gray of a few of General Rosser's command who have been hovering for a day or two on the rear and flanks of the enemy. They captured some stragglers, and amongst others three or four men left as safeguards at several houses, but they were released as good faith and the usages of war require."

These war-time notes have concerned the professors and students of the eventful session of I86o-6I, but these young men constituted a relatively small

${ }^{7}$ Personal Memoirs, Vol. II, p. I 16. 
percentage of the University of Virginia alumni who wore the gray. Of the less than nine thousand students matriculated before hostilities began as many as twenty-five hundred served in the Army or Navy, and more than half of these-the exact figure is put at fourteen hundred and eighty-were officers, a fact which shows the quality of the men; and four hundred and eighty-eight of them gave up their lives, an evidence of their faith and devotion. They were in all grades of the service from private to major-general, and even some of the boys at college in 1860 rose to be brigadier-generals.

They also took conspicuous roles in the civil service of the Confederate States-in the Provisional Congress, Senate, House, and Cabinet, and in the preceding Secession Convention; they went to Europe and Canada on confidential and diplomatic missions, and performed unnumbered services requiring a high grade of talent and training and the first order of integrity and patriotism. ${ }^{8}$

Such was the University's contribution to the civil and military services of the Confederacy. "The North sent no such army to the field," wrote a Federal officer" thirty years after the war. "It seemed always ready, active, resolute. Without doubt it was composed of the best men of the South rushing to what they considered the defense of their country against a bitter invader; and they took the places assigned to them, officer or private, and fought until beaten by superiority of numbers."

${ }^{8}$ For the services of Virginia alumni in the civil and military arms of the Confederacy, and a list of those rendering them, see p. 354 .

"General Whittier. See "Comments on the Campaign"viz, "Campaigns in Virginia, 1861-62," Vol. I of the Papers of the Military Historical Society of Massachusetts. 
They did not count the cost, but it would have been the same if they had. How great the sacrifice was cannot be estimated even now, but the next chapter contains an intimation of it. 


\section{CHAP'TER XVII}

\section{"FOR REMEMBRANCE"}

Confederate Cemetery Near the University-Buberd's Fine, BRoNze Figure of a CoNFEDERATE, Soldier-Ladies' MEMORIAL ASSOCIATION, AND THE D. A. R.-MEMORIAL TABLE'T-SOUTH'S SUPREME SACRIFICIAL, TRIBUTE.

The war over, service out of necessity gave place to memories. Out of the feelings and passions of that time of trial and suffering proceeded the efforts, so remarkably successful, to preserve the history of those sons of the University who put down their books at the first call to arms and grasped the sword. The women who had nursed in the hospitals or made uniforms at the court-house, where a station for this form of service was early organized, were the first to undertake effectively the preservation of Confederate history. ${ }^{1}$ They became The Ladies' Confederate Memorial Association, copied from the hospital registers the names of those who had died, the States from which they came and the companies and regiments to which they had belonged, had accurate maps of the cemetery grounds made, and themselves recorded the name and place of burial of every one interred there. This burying-ground adjoins the University cemetery at the foot of Mount Jefferson, just west of the University. In the midst of it

${ }^{1}$ The Jefferson Society, with whom the Washington united, by a series of resolutions which did much credit to the students of $1865-66$, inaugurated a movement to erect a monument in the soldier's cemetery, as yet an unenclosed space. The movement failed on account of the impoverished state of the South. 
stands a superb bronze figure by Gaspar Buberl, typifying the Confederate soldier, put there by this association, under the presidency of Mrs. Noah K. Davis.

This done-it was finished in 1893-these noble ladies who had kept "the lamp of chivalry alight in hearts of gold" undertook a service "for remembrance" for those sons of the University who made the supreme sacrifice for the Lost Cause in the period from I86I-65, and there were helpers at hand. On the I $5^{\text {th }}$ day of May, I894, Albemarle Chapter of the Daughters of the Confederacy was organized at Pavilion III, West Lawn, then the home of Prof. James Mercer Garnett, who had recently organized the John Bowie Strange Camp of Confederate Veterans in Charlottesville. The leading spirits in the movement were Mrs. Garnett and Mrs. Noah K. Davis, and united actively with them in the first work of this association were Mrs. S. Leterman, Mrs. Charles S. Venable, Miss Gillie Hill, Mrs. C. C. Wertenbaker, Mrs. W. H. Southall, Mrs. Green Peyton, Miss Vandegrift, Misses Meade, Mrs. George W. Olivier, Misses Cocke, Misses Berkeley, Mrs. John B. Minor, Miss Mary Minor, Mrs. F. P. Dunnington, Mrs. M. W. Humphreys, Misses Humphreys, and Mrs. M. G. Wallace. These began, but many others went with them. All warmly seconded every effort, and at last two great bronze tablets in the south portico of the Rotunda are graven with the names of five hundred University of Virginia men who had ideals and died for them. This is a roll of honor indeed, and the good fortune that it is as nearly complete as years of effort, guided by supreme devotion, could make it is due in a general way to these organizations, and in a particular sense, 
to two or three superior women of that high and worshipful type that put into hearts beating uncier ragged gray jackets a spirit that made the Confederate soldier the knightliest man-at-arms the world has ever seen.

THE HONOR ROLI

In Memory of the Students and Alumni of the University of Virginia who Lost Their Lives in the Military Service of the Confederacy from I86I to 1865 .

\begin{tabular}{|c|c|c|c|}
\hline Name. & Residence. & Place of death. & Date \\
\hline 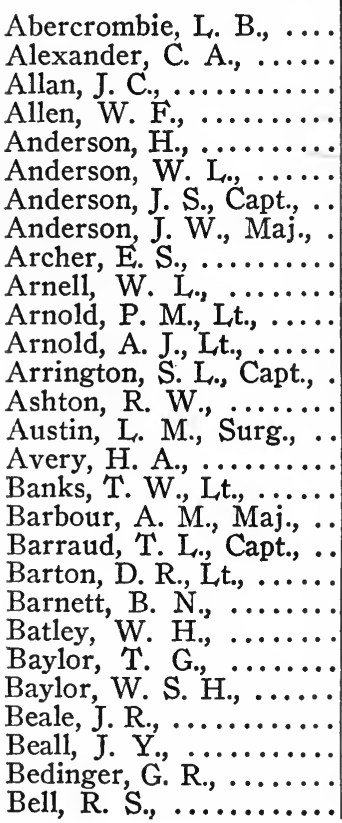 & 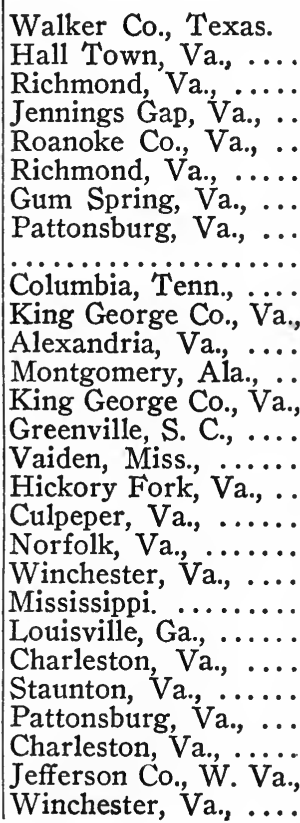 & 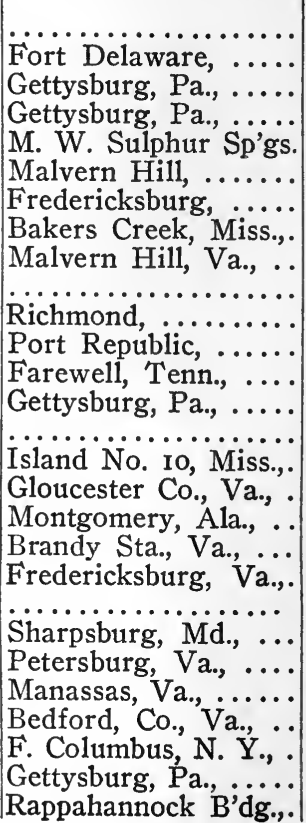 & $\begin{array}{l}1863 \\
1863 \\
1863 \\
1862 \\
1862 \\
1862 \\
1863 \\
1862 \\
1863 \\
1862 \\
1862 \\
1862 \\
1863 \\
1863 \\
1862 \\
1865 \\
1865 \\
1863 \\
1862 \\
1362 \\
1862 \\
1861 \\
1862 \\
1862 \\
1865 \\
1863 \\
1863 \\
183 \\
\end{array}$ \\
\hline
\end{tabular}




\begin{tabular}{l|l|l|l}
\hline \hline Name. & Residence. & Place of death. & Date. \\
\hline
\end{tabular}

Bell, L. R.

Berry, L. G

Bibb, F. S., Lt., ........ Bird, J. W.

Biscoe, T. H., Maj.

Bonner, .S. R., ........

Booton, W. S., .........

Boston, R. B., Col., ....

Bowles, T. B., ..........

Bowling, H. A., Capt., ..

Bowyer, E. F., Capt., ..

Bradford, R., ..........

Brawner, W. G., Capt. . .

Braxton, W. A., ........

Breckinridge, P.G.,Capt.,

Breckenridge, J., Capt., .

Broaddus, E. L., .......

Brockenbrough, A. A. G., Bronaugh, W. N., Maj., Brown, J. T., Col., .... Brown, A. J., Col., ..... Brown, S. W.

Buckner, T. D., Lt., ....

Buford, J. W., .........

Buist, E. S., Surg., .....

Burgess, S. N., Surg.,...

Burkhalter, J. E., Surg.,

Butler, E. G. W., Maj.,.

Butler, C. A., Capt., ....

Butler, W. B. Capt., ....

Butt, J. W., Lt., .......

Cabell, J. C., Lt., .........

Cardwell, J. R., ..........

Carr, J. G., Lt., .........

Carr, W. C., Lt., ....... Fauquier Co., Va....

Carr, J. G., ........... Charlottesville, Va.,. .

Carrington,W.C.P.,Capt., Charlottesville, Va.,. .

Carey, G. M., .......... Hickory Ford, Va., ..

Carson, S. M., Surg., .. Virginia, ...........

Charles, F. E., ......... Natchitoches, La., ...

Chalmers, J., ......... Halifax, Va., ........

Chalmers, H.C.,Asst.Sg., Halifax. Va., .........

Chancy, C. A., ......... Charles City C. H.,..
Malvern Hill, Va., .. 1862

Munsons Hill, Va., .. I I86r

Chancellorsville, Va.,. 1863

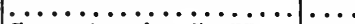

Spotts'vania C. H.,.. I864

Shenandoah, Va., .......

Gettysburg, Pa., .... 1863

High Bridge, Va., .. I 1865

................... I862

Richmond, Va., ..... 1864

Drewry's Bluff, Va.,. I862

Santa Rosa, Fla., .... I86I

Seneca Mills, Md., .. 1863

.................. I86

Kennons Landing,Va. I864

Petersburg, Va., .... I865

..................... I86

Gettysburg, Pa., .... I863

Richmond, Va., ..... 1862

Wilderness, Va., .... I864

................. I864

Staunton, Va., ...... I864

Spottsylvania C. H.,. 1864

Gettysburg, Pa., ..... I863

Hilton Head, S. C., . 1864

Stateburg, S. C., .... I86I

Fort Royal, S. C., ... I862

Belmont, ........... I86

Seven Pines, Va., ... 1862

Chancellorsville, Va.,. I863

Richmond, Va., ..... I862

Richmond, Va., ..... I863

.................. 1864

Dry Creek, Va., ..... I863

Seven Pines, Va., ... I863

E.dwards Depot, Miss., 1863

................. I864

Gloucester Co., Va.,. . I862

Tennessee, ...........

Arkansas, ........... 186

Fairfax, Va., ...... I86I

I865

I86I 


\begin{tabular}{l|l|l|l} 
Name. & Residence. & Place of death. & Date.
\end{tabular}

Chapman, G. B., Capt.,. . Union, Va., ........ $\left.\right|_{\text {Charlottesville, Va., .|1864 }}$

Chew, R. E., Col., ...... Renton, Miss., ...... Prairie Grove, ...... I86

Christian, H. B., Lt., ... Allens Creek, Miss.,.. Appomattox, Va., ... I 865

Clark, P. H., Capt., .... Halifax C. H., Va., .. Richmond, Va.., .... I862

Clay, C. G., ............ Lynchburg, Va., .... Spottsylvania C. H., . 1864

Cleaver, W. H., Capt., .. Camden, Ark., ...... Rio Grande, Va., ... ${ }_{1862}$

Cochran, J. L., ........ Staunton, Va., ...................... 1862

Cocke, P.St.G.,Brig.Gen., Bremo, Va., ............................

Cocke, W. H., Asst. Sg., Portsmouth, Va., ... Washington, D. C., .. 1865

Cocke, W. F., ......... Cumberland Co., Va., Gettysburg, Pa., ..... 1863

Cohen, G., ............. Savannah, Ga., ....... Bentonville, N. C. ... 1865

Coleman, L. M., Lt.-Col., Univ. of Virginia,... Fredericksburg, Va.,. 1863

Coleman, T. G., Lt., ... Halifax C. H., Va., .. Manassas, Va., ...... I862

Coleman, J. H., Maj.,... Athens, Ala., ....... Murfreesboro, Tenn., I86r

Coleman, C. L., Capt.,.. Dallas, La., .......... Spottsylvania, Va., .. 1864

Collins, W. G., ....... Campbell Co., Va., .. ….............. I86

Conrad, H. A., ........ Martinsburg, Va., ... Manassas, Va., ....... I861

Conrad, H. T., ........ Martinsburg, Va., ... Manassas, Va., .......

Cooke, W. M., ....... Portsmouth, Va., ... .................. 1865

Corbin, R., .......... Caroline Co., Va., ... Culpeper, Va.......... 1862

Cosnahan, J. B., Capt., .. Bennettsville, S. C.,. . Warren Co., N. C., .. I863

Cossit, C. E., Capt., .... La Grange, Tenn., .. Milton, Tenn., ...... I862

Cowan, C. S., Surg., ... Vicksburg, Miss., ... ................. I862

Cowherd, C. S., ....... Gordonsville, Va., ... Orange Co., Va.,..... 1863

Cowan, J. H., ........ Greensboro, Ala., .. Chancellorsville, Va.,. I863

Cox, J. E., Lt., ....... Chesterfield, Va., .................... 1865

Cropp, J. T., Surg., .... Stafford, Va., ........................ 1863

Cunliffe, W. E., ...... Tchula, Miss., ...... Chancellorsville, Va.,. I863

Davenport, N. J., ...... Tensas Par., La., .... ................ I86I

Davidson, G., Capt., ... Lexington, Va., ..... Chancellorsville, Va..,. 1863

Davidson, A., ........ Lexington, Va., ..... Lexington, Va., ..... 1864

Davis, R. B., Capt., .... Westmo'land Co., Va., .................. 1864

Davis, R., Capt., ....... Lewisburg, Va., ..... Woodstock, Va., .... ....

Davis, L. W., ......... Clarke Co., Va.. ..................... 1864

Doby, A. E., Capt., ... Ridgeway, S. C., .... Wilderness, Va..,.... 1864

Drewry, J. H., ........ Southampton, Va., .. Ashland. Va, ....... 1863

Dyson, L. M., ........ Fulton, S. C., ...... Charlottesville, Va.......

Earle, C. E., Capt., ..... Evergreen, S. C., .... Richmond, Va., ..... $\ldots$

Earle, W. R., ......... Anderson C. H., S. C., Manassas. Va., ....... i 86 i

Easton, E. W., ........ Mobile, Ala., ......... Richmond, Va.,....... 1862

Elliott, R. E., Jr., Capt., Beaufort, S. C., ...... Richmond, Va., ...... 1863

Elliott, R. H., Lt., ...... Savannah, Ga., ...... Atlanta, Ga., ........

Elliott, P., ........... Savannah, Ga., ....... Washington, D. C.... .. 1865

Ewing, D. P., .......... Botetourt Co., Va.., .. Botetourt Co., Va., .. II862 $_{\text {I }}$ 


\begin{tabular}{|c|c|c|c|}
\hline Name. & Residence. & Place of death. & Date. \\
\hline 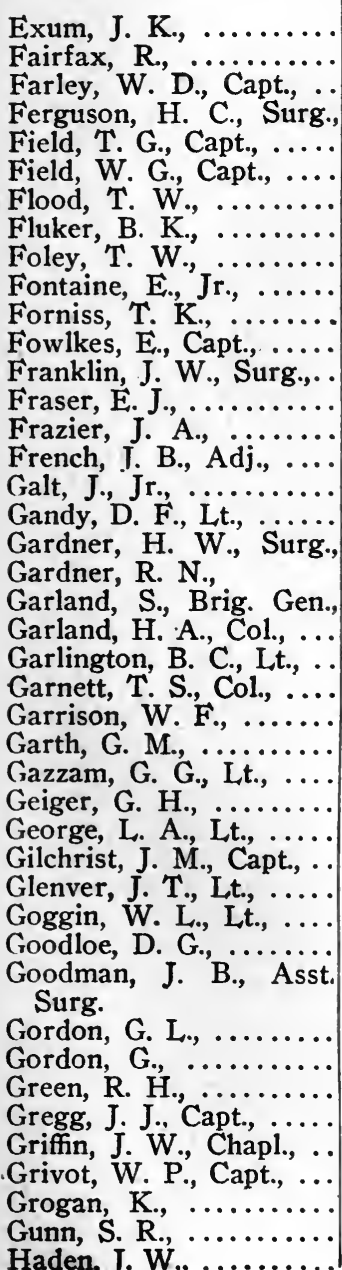 & 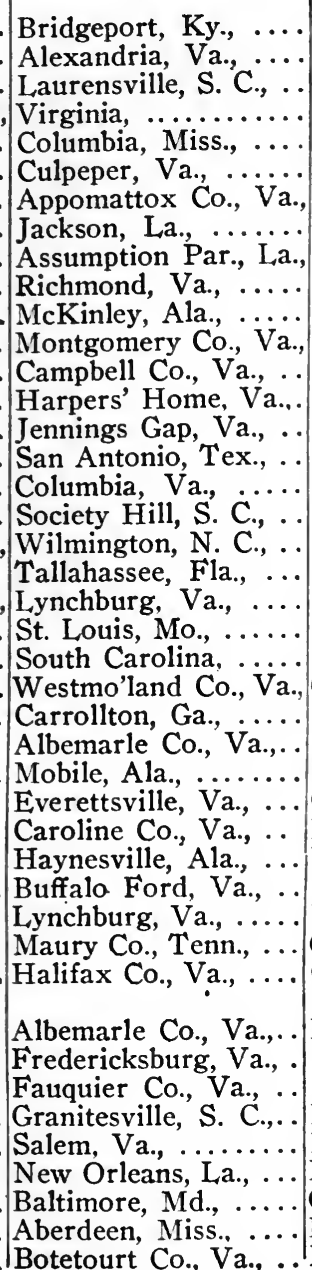 & 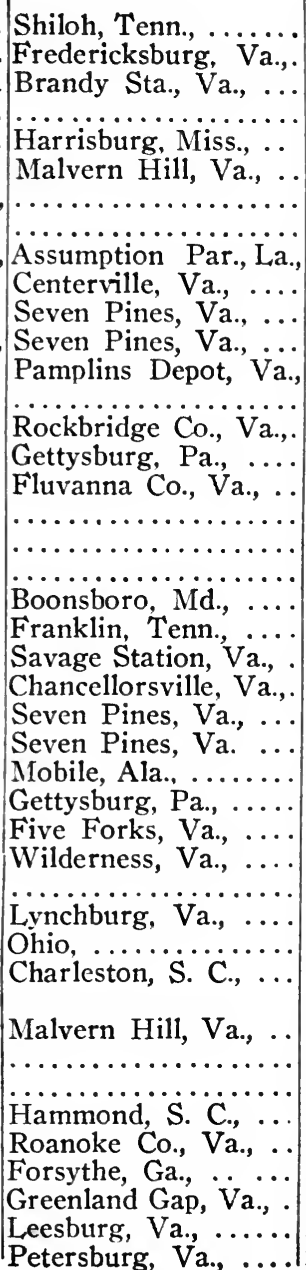 & $\begin{array}{l}1862 \\
1862 \\
\ldots \\
1865 \\
1865 \\
1862 \\
1862 \\
186 \\
1865 \\
1861 \\
1862 \\
1862 \\
1865 \\
186 \\
1862 \\
1863 \\
1862 \\
1861 \\
1862 \\
1862 \\
1862 \\
1864 \\
1 \ldots 2 \\
1863 \\
1862 \\
1862 \\
1865 \\
1863 \\
1863 \\
1865 \\
1862 \\
1862 \\
1861 \\
1861 \\
1864 \\
1862 \\
186 \\
186 \\
186 \\
103 \\
1864 \\
1863 \\
1861 \\
1864\end{array}$ \\
\hline
\end{tabular}




\begin{tabular}{l|l|l|l|}
\hline \hline Name. & Residence. & Place of death. & Date. \\
\hline
\end{tabular}

Hairston, G. S., ....... Hagerstown, Md., .. Hairston, H., ......... Yalabusha, Miss., ... Hale, S., Capt., ....... Rocky Mt., Va., ..... Hall, G. A., Lt., ........ Greenville, Ga., ..... Hall, R. H., Capt., ..... Nor'umb'land Co., Va. Hall, B., Col., ......... Montgomery, Ala., .. Halliday, D. W., ....... Lumpkin, Ga., ...... Hambrick, J. A., Maj.,. . Franklin Co., Va., ... Hamer, C. F., Capt.,. . . Claiborne Co., Miss., Hamilton, D. H., Col.,. . Charleston, S. C., ... Hamlet, J. C., Lt., ..... Charlotte Co., Va., .. Hamlin, W. B., Adj.,... Fluvanna Co., Va.,. . Hammond, G.W.,Lt.Col., Fincastle, Va., ...... Hamner, N. B., ........ Univ. of Virginia,... Hancock, W. H., ...... Chesterfield Co., Va.,. Hare, T. E., Lt., ....... Macon, Tenn., ....... Harmanson, J. R., Lt.,. . Northampton, Va., .. Harrison, B., Capt., .... Prince George, Va.,. . Harrison, D. C., Capt.,. . Cumberland, Va., ... Harrison, J. P., ....... Richmond, Va., .... Harrison, J. W., ....... Prince Geo. Co., Va.,. Harvey, G., Capt., ..... Saline Co., Mo., ..... Harvie, C. I., Capt., .... Amelia Co., Va., ... Harvin, W. E., Capt., .. Duncansville, Ga., .. Haskell, W. T., Capt.,. . Abbeville, S. C., ..... Hays, J. S., .......... Coleraine, N. C., .... Healy, E. M., Capt., .... Middlesex Co., Va.,. . Heath, R. B., Adj., ..... Petersburg, Va., .... Hemphill, R., ......... Blackstocks, S. C., .. Henderson, L. A., Capt., Salisbury, N. C., .... Hendrick, R. L., ....... Palmer's Sp'gs, Va.,. Henry, J. F., Maj., ...... Hicks, J. H., ............ Hobbs, T. H., Col., .... Hobson, A. M., Capt., .. Hobson, A. M., Capt., .. Richmond, Va., .... Hodges, T. P., Capt.,. . . Okolona, Miss., ..... Hoffman, T. W., Lt., ... Weston, Va., ......... Holcombe, H. L., Adj., . Holcombe, J. C., Capt.,. S Savannah, Ga., ..... Holladay, J. M., ....... Albemarle Co., Va.,. . Albemarle Co., Va., .. Holland, N. W., Capt.,. . Tallahassee, Fla.... Olustee, Fla., Wa., .. 1862 Holleman, G. C., ...... Jacksonville, Fla., ... Seven Pines, Va...... Holman, B. O., Capt., .. White Hall, Ala., ... Fort Delaware, Md.,. I863 Holmes, A. T., ........ Rehoboth, S. C., .... Oxford, Miss., ...... 


\begin{tabular}{l|l|l|l}
\hline Name. & Residence. & Place of death. & Date. \\
\hline
\end{tabular}

Hull, J. M., Stafford Co., Va.,... Fairfax C. H., Va., .. I862 Hungerford, T. J., Capt., Westmo'land Co., Va., Hunter, L. M., Capt., .. Hunter, R. M. T., Jr.,. . Hunter, B. B.e Capt., .. Hutton, W. B., Lt., .... Irving, C., ............. Irving, J. R., ......... Jackson, J. B., .......... Jackson, A., ............ James, R. E., $\cdots \cdots \cdots \cdots$

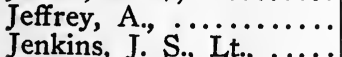
Jenkins, M. A., ........ Southampton Co., Va... Richmond, Va., .... Jones, E. J., Col., ....... Athens, Ala., ........ Jones, C. A., Capt., ..... Nottoway C. H., Va..,. Jones, J. G., Capt., ...... Palmers Sp'gs, Va.,. . Jones, J. L., ............ Virginia, ........... Jones, J. T., ........... Carrolton, Ala., ...... Jones, L. B., ............ Falmouth, Va., ...... Jones, T. R., Capt., ..... Charlottesville, Va.... Jones, F. P., Lt., ....... Louisa C. H., Va., ... Jordan, W. J., Surg., .. Roxboro, N. C., ..... Jordan, J. W., ......... Huntsville, Ala., .... Keels, W. E., Capt., ..... Murrys Ferry, S. C.,. Kemper, G. B., Lt., .... Port Republic, S. C.,. Kilpatrick, F. W., Col.,. Pendleton, S. C., .... Kinchloe, W. J., Lt. Adj. Fauquier Co., Va., ... Lamar, C. A., ...........

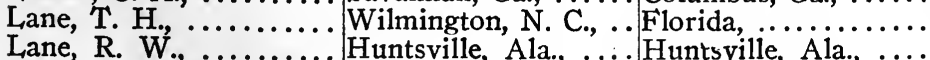

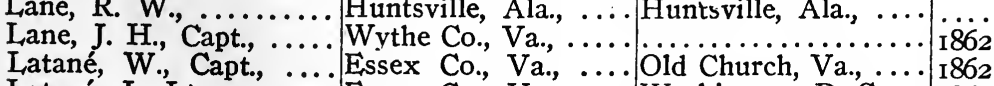
Latené, J., Lt., ........ Essex Co., Va., .... Washington, D. C., .. 1864 Latham, R. P., L.t., ...... Culpeper Co., Va., ... Culpeper C. H., Va., . 1862 Laurens, J., .......... Navy, ............. Charleston, S. C., ... 1865 Leftwich, J. W., Surg.,.. . Liberty, Va........... Pittsylvania Co., Va., $\ldots$ Leigh, J. R., Lt. Col., ... Halifax, Va., ........ Corinth, Miss., ...... Leigh, R. W., Lt. Col.,.. Randolph Macon Col. Corinth, Miss., ....... 1863 Lenoir, W. H., ....... London, Tenn., .... Bowling Green, Ky.,. I86I Lewis, G. N., ........ Monterey, Ala., ..... Sharpsburg, Md., ... 1862 Lewis, J. Lt., ........... Charlestown, Va., ... Winchester, Va., ....

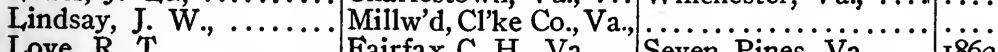
Love, R. T. ........... $\mid$ Fairfax C. H., Va., .. S Seven Pines, Va., .... $\left.\right|_{1} \ddot{862}$ 
Name.

Residence.

Place of death.

Date.

Lowry, J. M., ........

Luckett, F. E., Surg., ..

Luckett, L. M., ........

Lyles, W. B., Capt., ....

Macleod, F. H., .........

Magruder, J. B., Col., ..

Magruder, J. W., Lt., ..

Magruder, J. H., Capt.,

Major, E. P., Lt., ......

Manning, R. I., Capt., ..

Markham, R. A., ......

Marsh, D., Lt., .........

Marshall. T., Lt. Col., . .

Martin, G., ...........

Martin, T., Capt., ......

Massie, J. L., Capt., ....

Massie, R. T., .........

Mastin, G. B., ..........

Maupin, J. R., ............

Maury, J. H., Lt., ......

Meade, H. E., ..........

Meem, A. R., Surg., ...

Meem, J. L., Capt., ....

Meredith, W. B., Lt., ..

Merritt, H. E., .......

Merritt, W. T., ........

Metcalf, C., Lt., $\ldots . . .$.

Middleton, A., ..........

Minor, W. B., ...........

Moore, J. W., Maj., ....

Moore, W., .............

Moore, A. C., …..... Spartansburg, S. C.,

Morrill, W. T., ........ Alexandria, Va., ...

Morris, W., ......... Charlottesville, Va.,. .

Morris, G. W., ........ Pr. Anne Co., Va.,..

Morrison, R. J., Maj.,... Virginia, .............

Morton, W., .......... Columbus, Miss., ....

Morton, A., ........... Richmond, Va., .....

Mosby, L., Lt., ........ Lynchburg, Va., $\because \mathrm{V}^{\circ}$

\begin{tabular}{l|l|l|l|l} 
Moseley, H. L., & M....... & Buck'ham C. H., Va., & Buck'ham C. H., Va., & I862 \\
Munford, C. E., Lt., ... & Richmond, Va., ..... & Malvern Hill, Va., .. & 1862
\end{tabular}

Richmond, Va., ..... 1864

Middleburg, Va., ... Richmond, Va., ..... 1863

Middleburg, Va., .... Gaines Mill, Va., .... I862

.

Albemarle Co, Va.......................... ${ }_{1863}^{1863}$

Albemarle Co., Va.,. . Meadow Bridge, Va., 1864

va., ................... 1863

Va.,.. Seven Pines, Va., ... 1862

Fulton, S. C., ....... 1861

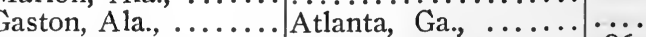

Oak Hill, Va., ..... Fishers Hill, Va., ... I864

. Albemarle Co., Va.,.. I 1865

. Malvern Hill, Va., .. 1862 Richmond, Va., ..... 1863

Seven Pines, Va., ... 1862

Gettysburg, Pa., .... I 1863

\begin{tabular}{ll|l} 
Gettysburg, Pa., .... & 1863 \\
Vicksburg, Miss., ... 1863
\end{tabular}

Richmond, Va., ..... Resaca, Ga., ........ 1864

Petersburg, Va., ....Petersburg, Va., .... I862

.

Richmond, Va., ...... Richmond, Va., ..... $^{\text {Seven Pines, }}$

Brunswick, Va., ..... Mississippi, ......... 1863

Natchez, Miss., ...... Charlotte C.

Southampton Co., Va., Texas, ............. 1864

Abemarle Co., Va.,.. Charlottesville, Va.,.. ....

St. John's, N. C., .... . .

Five Forks, Va., .... 1865

2d Manassas, Va., ... 1862

Alexandria, Va., .... 1862

Cold Harbor, Va., ... 1862

Petersburg, Va., .... 1862

Gettysburg, Pa., ..... 1863

Williamsburg, Va., .. I86I

Shiloh, Tenn., ....... 1862

Gettysburg, Pa., ..... 1863

Wytheville, Va., ... 1863

McAfee, M., Maj., ...... Charleston, Miss., ...|Jackson, Miss., ....... 


\begin{tabular}{|c|c|c|c|}
\hline Name. & Residence. & Place of death. & Date. \\
\hline
\end{tabular}

McAllister, J. N., Lt., .. Munroe Co., Miss., .. $\mid$ Okolona, Miss., .... I I86r McCormick, C., Surg.,. . Berryville, Va., ..... Berryville, Va., ..... .... McCoy, W., Capt., ..... Pendleton, Va., ...................... McCoy, W. K., ........ Univ, of Virginia, ... Charlottesville, Va.,.. .... McDaniel, J., ......... King Geo. Co., Va.,.................... McDonald, C. W., Capt., Winchester, Va., .... Gaines Mills, Va., ... 1862 McDowell, T. P., ...... Abington, Va., ...... Gordonsville, Va., ... 1862 McElmurry, W. L., .... Burke Co., Ga., ...... Manassas Junc., Va.,. I86I McGehee, N. M., ...... Louisa Co., Va., ....................... McIntyre, A., Lt., ...... Marion, S. C., ...... Sharpsburg, ........ I862 McIver, J. K., ......... Darlington, S. C., ...P Point Lookout, ...... I863 McKerall, W., ........ Franklin, La., ...... Camp Douglas, I11., .. ... McKim, R. B., ........ Baltimore, Md., ..... Winchester, Va., ... I862 McMillin, J. M., ....... Thompkinsville, Ky.,. Franklin, Tenn., .... 1862 McMurry, A. G.,...... Cassville, Ga., ....... McPherson, S., Asst. Sg., Greenbrier Co., Va.,. . Nelson, H. M., Maj., ... Hanover Co., Va., ... Nelson, J. A., Surg., ... Bedford Co., Va., ... Nelson, H., Capt., ....... Forest Depot, Va., .. Newman, S. W., Lt.,.... Gordonsville, Va., ... Newman, T. H., ....... Gordonsville, Va., ... Newton, T., Surg., ..... Norfolk, Va., ....... Newton, W. B., Lt. Col., Westmoreland, Va.,. . Newton, J., Capt., ..... El Dorado, Ark., .... Otey, G. G., Capt., ..... Lynchburg, Va., .... Page, Mann, .......... Albemarle Co., Va.,. . Paine, $H_{.} R_{\cdot 2} \ldots \ldots \ldots$ Lexington, Va., ..... Palmer, J. S., Capt., .... Charleston, S. C., ... Palmer, S. D., ........ Charleston Dis., S. C., Palmer, J. J., .......... Charleston Dis., S. C.. Parker, W. F.,......... Snow Hill, Md., ..... Parker, W. H. H., ...... Sussex Co., Va., .... Pate, H. C., Col., ....... Cross Roads, Va., ... Patterson, R. B., Capt., Virginia, .............. Paxton, E. F., Br. Gen., Lexington, Va.......... Peake, W. B., Eng., .... Spottsylvania, Va., .. Peebles, L. J., .......... Petersburg, Va., .... Peek, W. H., Surg., .... Hampton, Va., ....... Peeples, P. A., Capt., .. Canton, Miss., ...... Pegram, W. J., Col., ... Richmond, Va., ..... Five Forks, Va., .... I865 Pendleton, A. S., Lt. Col., Lexington, Va., ..... Woodstock, Va., .... 1864 Pendleton, P. H., ...... Frederick's Hall, Va., Spottsylvania, Va., ... 1864 Peyton, R. L. G., Col., .. Ohio, ............................

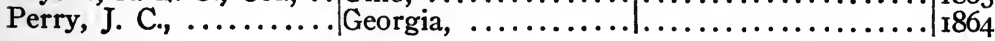




\begin{tabular}{|c|c|c|c|}
\hline Name. & Residence. & Place of & Date. \\
\hline 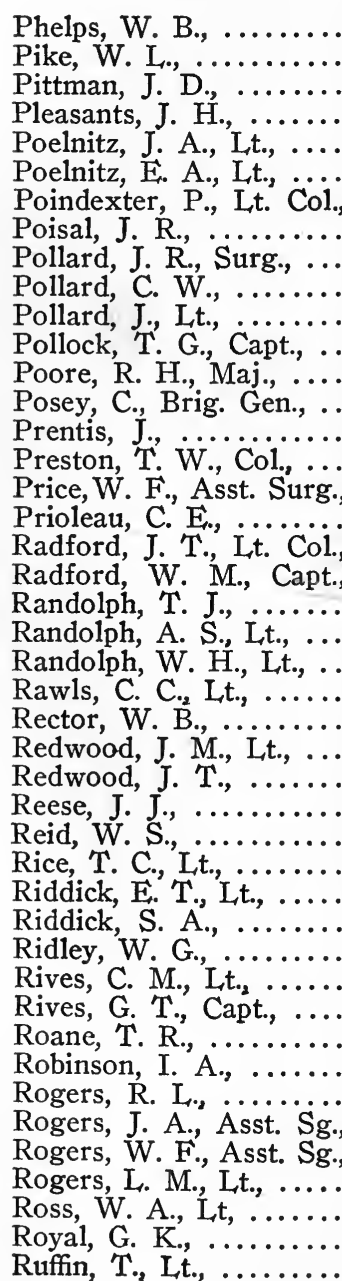 & 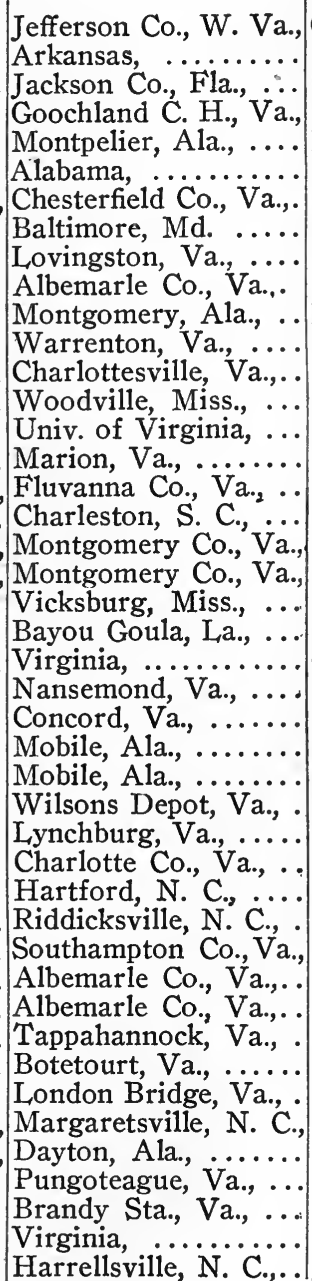 & 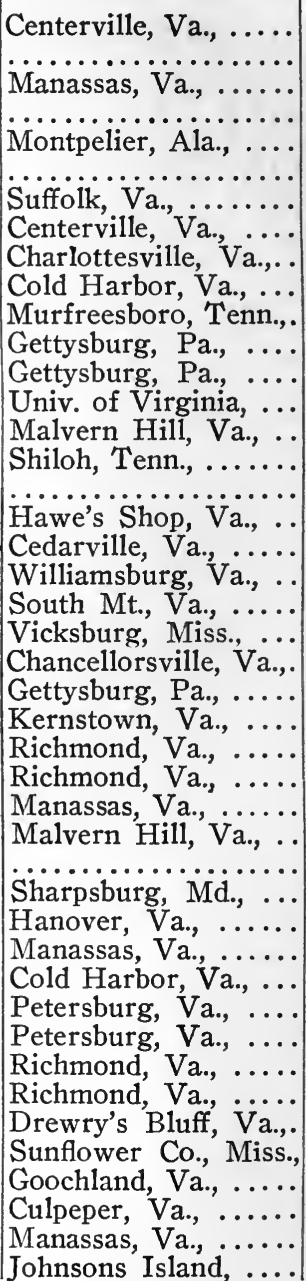 & $\begin{array}{l}1861 \\
130 \\
1862 \\
1864 \\
1865 \\
1865 \\
1864 \\
1861 \\
1862 \\
1864 \\
1863 \\
1863 \\
1863 \\
1863 \\
1863 \\
1862 \\
1862 \\
1862 \\
1864 \\
1864 \\
1861 \\
1861 \\
1862 \\
1862 \\
1863 \\
1863 \\
1862 \\
1865 \\
1865 \\
1861 \\
1862 \\
1862 \\
1862 \\
1863 \\
1863 \\
1862 \\
1864 \\
1865 \\
1863 \\
1863 \\
1864 \\
1864 \\
1862 \\
1864 \\
1864 \\
1362 \\
1862 \\
1864\end{array}$ \\
\hline
\end{tabular}




\begin{tabular}{|c|c|c|c|}
\hline Name. & Residence. & Place of death. & Date. \\
\hline 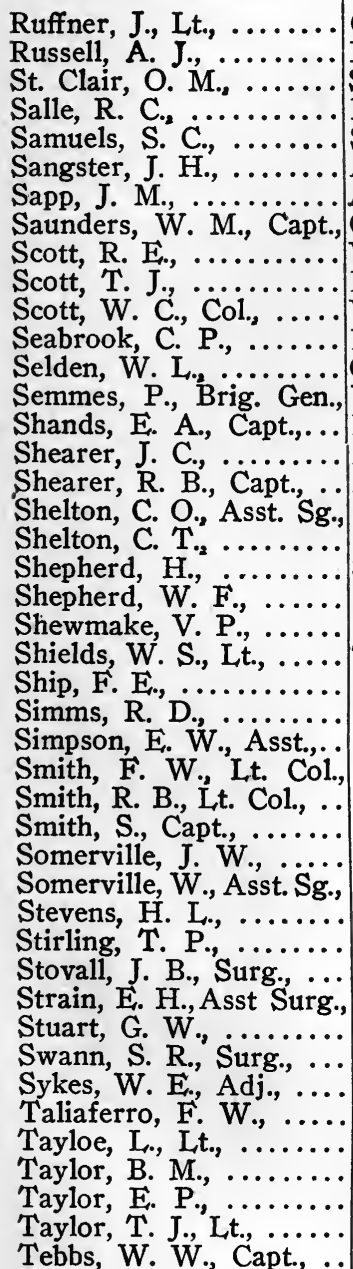 & 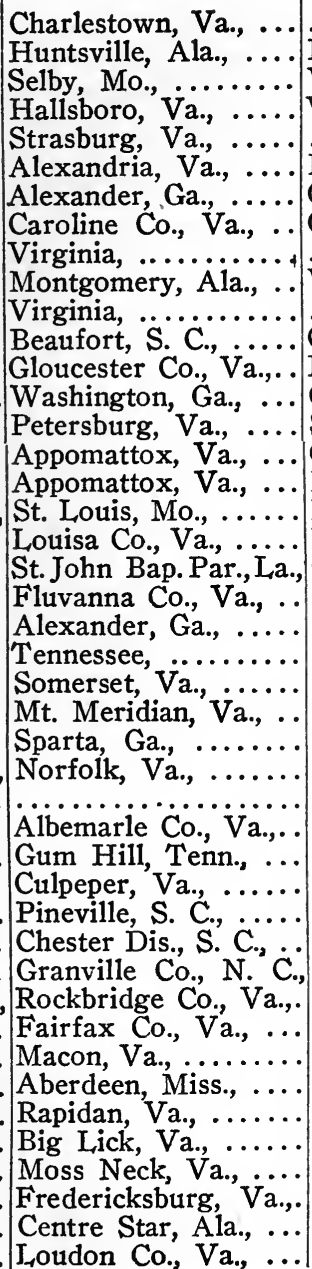 & 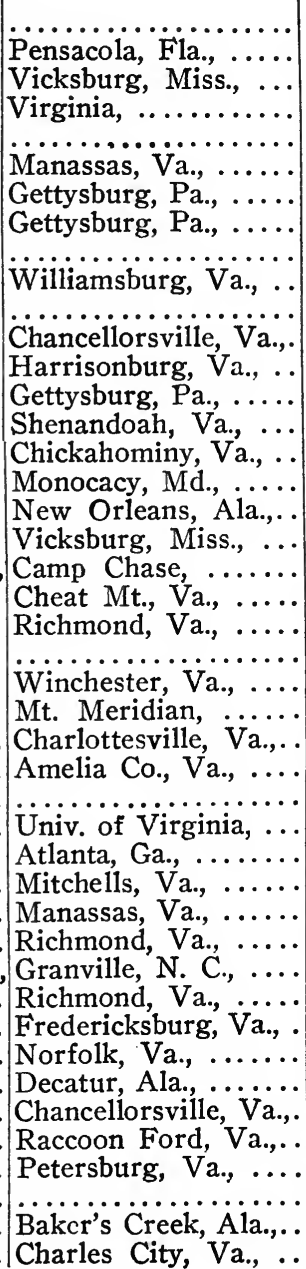 & $\begin{array}{l}1363 \\
1863 \\
1862 \\
1864 \\
1864 \\
1862 \\
1863 \\
1863 \\
1862 \\
1862 \\
1863 \\
1863 \\
1865 \\
1862 \\
1863 \\
1861 \\
1863 \\
1864 \\
1862 \\
1862 \\
\ldots \ldots \\
\ldots 1362 \\
1862 \\
1862 \\
1862 \\
1862 \\
1861 \\
1861 \\
1865 \\
1865 \\
1864 \\
1864 \\
1864 \\
1862 \\
1862 \\
1863 \\
1863 \\
\ldots 136 \\
1864 \\
1863 \\
1862 \\
1864 \\
1863 \\
1863 \\
1864 \\
1864 \\
1862\end{array}$ \\
\hline
\end{tabular}




\begin{tabular}{|c|c|c|c|}
\hline Name. & Residence. & Place of death. & Date. \\
\hline 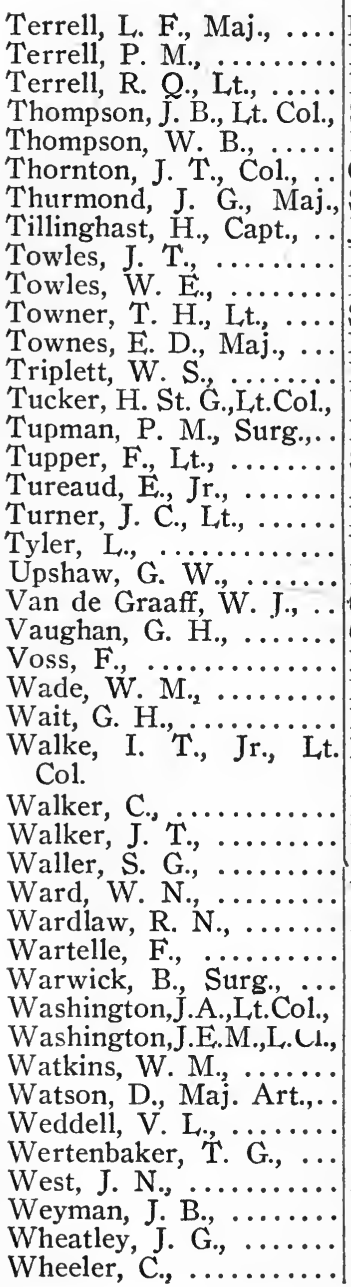 & 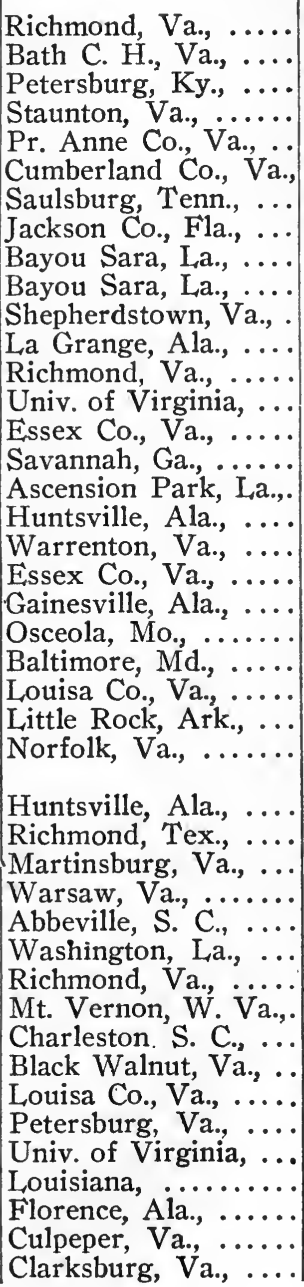 & 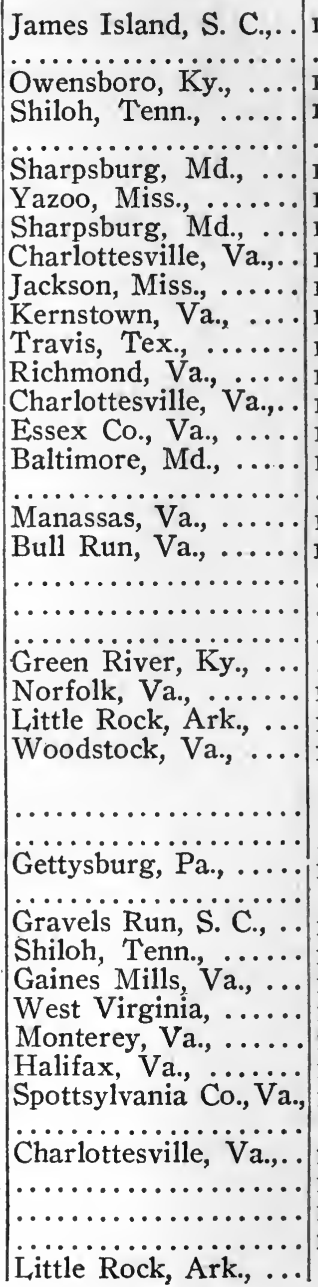 & $\begin{array}{l}1864 \\
1365 \\
1862 \\
\ldots \\
1862 \\
186 \\
1862 \\
1861 \\
1863 \\
1862 \\
1864 \\
1863 \\
1863 \\
1863 \\
1865 \\
\ldots \ldots \\
1861 \\
1861 \\
\ldots \ldots \\
\ldots \ldots \\
\ldots \ldots \\
106 \\
1862 \\
1863 \\
1864\end{array}$ \\
\hline
\end{tabular}




\begin{tabular}{|c|c|c|c|}
\hline Name. & Residence. & Place of death. & Date. \\
\hline 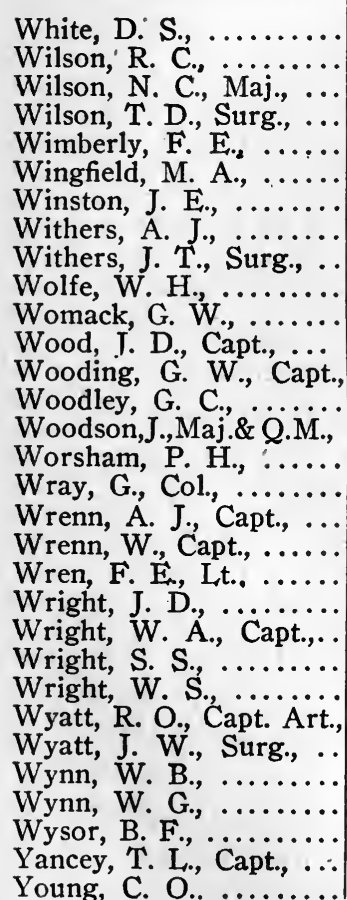 & 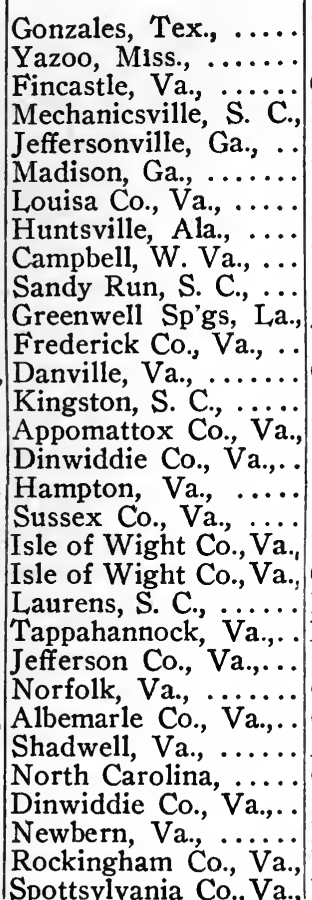 & 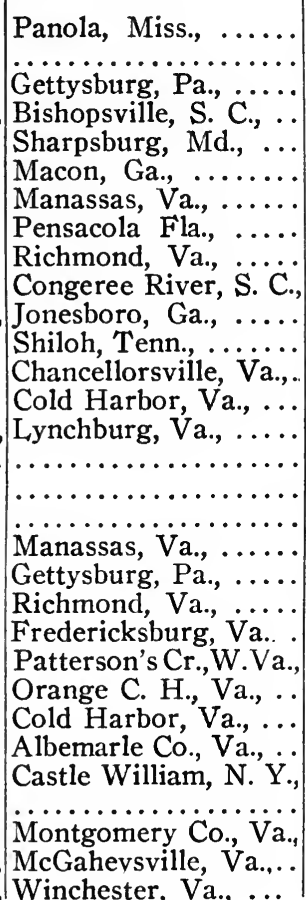 & $\begin{array}{l}1863 \\
1863 \\
1863 \\
1865 \\
1862 \\
1861 \\
1862 \\
1862 \\
1861 \\
1862 \\
1386 \\
1864 \\
1366 \\
1862 \\
1864 \\
1864 \\
1863 \\
1864 \\
1864 \\
1864 \\
1862 \\
1863 \\
1 \ldots \\
1862 \\
1864 \\
1863 \\
1864 \\
1861 \\
1864 \\
1862 \\
1863 \\
1862 \\
1862\end{array}$ \\
\hline
\end{tabular}




\section{CHAPTER XVIII}

\section{THE LITERARY SOCIETIES}

Patrick HeinRY Society-JeFFERSON SOCIETY-ITS HistoryMadison, Monroe, aNd LaFayetTe Honorary MEMBERS-JEFFERSON DECLINED MEMBERSHIP FOR OFFICIAI, REASONS-WASHINGTON SOCIETY-ITS HISTORY-ANTE

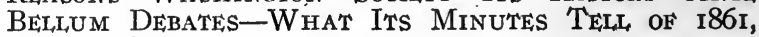
AND OF 1865 .

In the first months of the session of 1825 -which extended from March I to December I5-the Patrick Henry Literary Society was organized with a membership nearly equal to the total number of students. There are occasional references to this society in the minutes of the faculty and also in the records of the Visitors. The meetings were held for a time in the lecture-room in Pavilion II, at the north end of East Lawn, then occupied by Dr. Johnson, the demonstrator of anatomy. In I829 the Visitors gave the Henryites notice to hold their sessions in one of the vacant hotels, and this is the last heard of them.

This society was yet in the first months of its life when sixteen of its members seceded and founded the Jefferson, which met at first weekly, and then fortnightly, in the lecture-room in Pavilion $I$. Later it convened in first one and then another of the class-rooms until finally housed in Hotel $\mathrm{C}$ on West Range, now known as Jefferson Hall.

The history of the Jefferson was given as the introductory explanation to the second catalogue of the society in 1859 by an editorial committee consisting of R. Randolph Hutchinson of St. Louis, 
afterwards a major C. S. A., Joseph E. Cox, Jr., of Chesterfield Court House, who died in December, I86I, while serving as a lieutenant of artillery, and Bennett Taylor of Kabletown, Va., afterwards a colonel in the Confederate service. It is reproduced here for the information it contains as to the Jefferson and other literary societies:

"On the I4th day of July, I825, a number of students met in Dormitory No. 7 , West Lawn, for the purpose of organizing a society for debate and literary improvement. At this meeting three gentlemen, Edgar Mason [of Charles County, Md̂.], John H. Lee [Fauquier County, Va.], and William G. Minor [Fredericksburg, Va.], were appointed a committee to frame a constitution for the regulation of the society, which was adopted at a meeting held July I8, in Dormitory No. 5. On this occasion an election of officers was held, after the adoption of suitable titles by which to distinguish them, resulting in the choice of Edgar Mason, Moderator; John H. Lee, Vice-Moderator; Mann A. Page [Richmond], Secretarius; and J. N. Tazewell [Norfoik, Va.], Bibliothecarius. Secrecy was strictly maintained with regard to all that concerned the society, and the penalty for violation of this law was expulsion. In I826 a new officer was instituted, whose duty it was to assess all fines for disorder, and a regular court was held after each meeting, presided over by two judges, who heard all appeals respecting fines, and decided on them ultimately, always doubling the amount of the original fine if the appeals were not sustained. This custom was maintained up to about 1838 , when it was found to be useless and cumbersome, and accordingly abolished. It has been adopted, however, by some societies of a later date, 
and is, we believe, maintained in one. For many years it was a part of the regular exercises of the society to read essays on various subjects, a custom entirely disused at present. The constitution of the society, though often revised and enlarged, still contains a great deal of the original one, and the preamble now used is essentially the same as the one first proposed in 1832 .

"The first badge adopted by the society was ordered 'to consist of a bunch of ribbon, the colors of which were to be blue, white and pink, to be worn on the left lapel of the coat;' this was to be worn by the members on 'particular occasions.' Afterward it was ordered that the badge of the society be a small medal, with an appropriate motto, 'the device, a scroll, on which appears the Declaration of Independence transversed by a spear, surmounted with the cap of Liberty; on the reverse shall be the name of the society, its date of birth, encircled by a wreath of laurel. The seal shall be the front of the device, with the motto, Pro Patria, Pro Libertate, atque Pro Litteris.' Both these badges were adopted in the course of 1825 . In I834 a badge of blue ribbon was chosen by the society, to be worn on public occasions, and blue has ever since continued to be the color of the Jefferson Society, the white and pink originally worn having been adopted by other literary bodies of the University. There seems to have been no badge worn commonly by the members of the Jefferson until I848, when a committee recommended for adoption the present style, viz: Jeff. Soc. U. V., with two pens crossed, and at the bottom, the Greek letters Phi Kappa Theta.

"The anniversary celebrations were originally held in some one of the churches of Charlottesville, 
and frequent mention is made in the minutes of committees appointed 'to have a stage erected in front of the pulpit of the Episcopal Church.' They seem also to have been held in the daytime, until the faculty interfered to prevent it. In I825 it was resolved to celebrate the anniversaries of the foundation of the University of Virginia, the birthdays of Jefferson and Washington, the fourth of July, the surrender of Yorktown, and the birthday of Patrick Henry. They must have found this rather too much for them, since in 1832 it is recorded that a motion was necessary to be made and carried, to elect annually an orator and a reader of the Declaration of Independence for the anniversary of the birthday of Jefferson. The final oration has always been delivered on the day before Commencement, not without some quarrels with other societies, however, before courtesy and long prescription had settled the point.

"There have been quite a number of rival societies started, which appear and disappear on the record books of the Jefferson, leaving there the sole memorial of their existence. The first mentioned is the Patrick Henry Society, in 1825 ; it does not seem to have lived very long. In 1826 the Medical Society appears, then in 1833 the Academic. In 1836 the first notice of the Washington Society appears in the shape of an invitation to it and another, the Gamma Pi Delta, to engage with the Jefferson in a public debate, which however does not seem to have been accepted. Since that time the Parthenon, the Philomathean, and various others have been born and have died. The last formed is the Columbian.

"The society honors have all along remained pretty much the same-an anniversary and valedictory oration, and a readership of the Declaration of 
Independence on the $\mathrm{I} 3^{\text {th }}$ of April. During the session of $1856-57$ it was determined to give a gold medal of the value of fifty dollars to the member who shall prove himself to be the best debater during any session. Formerly a diploma was given to each member who, on leaving college, was adjudged to have fulfilled his society duties faithfully, but this has been discontinued.

"Many attempts have been made by the Jefferson, in conjunction with her sister societies, to establish a magazine at the University, but with small success, until two sessions ago. The Jefferson Monument Magazine, the Collegian, and others, were the fruits of these endeavors, but all had a brief period of existence, until $1856-7$, when the present Virginia University Magazine was established by the three societies, on a footing which bids fair to render it a permanent institution in College. The societies then determined jointly to award a gold medal for the best contribution appearing in each volume, to be determined by a committee of the professors; the first medal was awarded to a member of the Jefferson Society, at its final celebration in I858."

This catalogue is very rare and valuable. Fortunately it contains a list of the members, with indications of those upon whom the various honors of the society were bestowed within the period between 1825 and 1859 . The minutes covering a period of fifty years (1825-I875), deposited in the library for safe keeping, were lost in the fire of 1895 . One volume escaped-the roster of the society from I 859 to I885-which makes it possible to complete the list of members from where the catalogue left off. The names of many distinguished men appear in the roll-among them those of Poe and Thompson. 
Poe, by appointment, read an essay-subject "Cold and Heat"-participated in several debates and on at least one occasion performed the duties of secretary. His signature to the minutes as such was cut from the book by some unscrupulous collector, and is the sole survival of that record, if indeed it has escaped destruction.

Honorary membership was not disdained. Robert A. Thompson of Kanawha County, Virginia, proposed Mr. Jefferson, which elicited the following letter addressed to Edgar Mason, J. W. Brockenbrough and J. W. Saunders.

\section{"Monticeilo, Aug. I2, I825.}

"I am very thankful, gentlemen, for the honor done me by the society of which you are a committee, in electing me one of its honorary members. I could decline no distinction conferred by them or service I could render them, but on reasons of still higher importance to themselves. On maturely weighing the general relations in which the law of the University and the appointment by its Visitors have placed me as to every member of the institution, I believe it my duty to make no change in these relations by entering into additional and different ties with different associations of its members. The duties with which I am charged require that in all cases which may arise I shall stand in an equal position as to every person concerned, not only that I may preserve the inestimable consciousness of impartiality to all but the equally inestimable exemption from all suspicion of partiality. Your kind expressions toward myself ensure to me, I hope, an equally kind acceptance of the reasons on which I I6 
act, and I can add with truth on behalf of my colleagues of the visitation, that the highest reward they can receive from their joint cares and exertion in behalf of this institution is the anticipated hope and belief that they are rearing up in science and in virtue those on whom the hopes of this country rest for its future government and prosperity. For myself I pray you to accept assurances of my sincere affections and best wishes.

"TH : JEFFERSON."

Mr. Madison and Mr. Monroe were not constrained by such considerations and accepted. General Lafayette, who was in America that year, and was entertained at dinner in the unfinished Rotunda, was proud to be enrolled. John Randolph of Roanoke was proposed, but failed of election because of his opposition to the election of Monroe to the Presidency. That gentleman was Mr. Jefferson's candidate.

It would be impossible, both because of limit and the imperfect character of the records, to produce all the officers of various grades who have served the society since its organization. Even those who filled the presidential chair ${ }^{1}$ would make a long record. During the sessions of $1825-26$ no less than twelve attained to that eminence. The presiding officers whose incumbency covered the intermediate and final terms enjoyed a distinguished honor. Until about I870 there were two celebrations each session. The intermediate was in commemoration of Jefferson's birth. Frequently the grounds were illuminated, often what was called "the anniversary oration" was delivered by some member, and always

${ }^{1}$ See p. 359 for list of final presidents, medalists, \&c. 
the Declaration of Independence was read. The three honors-the presidency, oratorship and the readership-were highly prized, and much time and care were given to preparation for the creditable discharge of the duties they imposed.

The final celebration was regarded as the event of the college year. The assemblages which at the "intermediate" were composed in the main of local residents were attended in June-in the earlier years in July-by persons from all parts of the State and even beyond, and the event had a place in the closing exercises of the session. The president and the valedictorian-afterwards he was a medalist-were men of marked eminence, and used their utmost endeavors to measure up to the distinguished character confered upon them by the suffrages of their fellow-students. Following the descriptions of some of these occasions which appear in the student publications one must conclude that everything was brilliant-with lights, beauty and bright eyes, and "as noisy as heaven since the noise was made by the angels" with bright eyes; "a joyful noise, too, except to the speakers and those who wished to hear them."

Tribute must be paid to the truth of history. The Board of Visitors, for some reason, took it into their heads to disapprove of illuminations on the Lawn and oratorical pyrotechnics in the Episcopal Church, or wherever these early celebrations took place, and they passed a resolution. The Collegian, then in the first of its four years of existence, protested in the following editorial from the pen of Barbour, Critcher, Gooch, Holcombe or Watts, probably Holcombe:

"It is no doubt known to most of our readers that 
by a resolution of the Board of Visitors passed about two years since the celebration of anniversaries and delivery of literary addresses in public is prohibited to the students of this institution. This fact has often been made a subject of regret (not to say reproach) on the part of some of our warmest friends, and we are pleased to learn that an effort is about to be made, with a strong probability of success, to reestablish the honored usage amongst us. Firm as all are convinced of the utility of public addresses it is indeed mortifying that a custom, venerable in time, and sanctioned by the happy experience of all other colleges, should be prohibited our use. We are forbidden to speak, the tongue falters, the lips are closed, and the voice of vivid eloquence must ring through our Corinthian columns no more. The effect of the present policy will be to hush up all emulation and render neglected the cultivation of elocution. Public spirit will linger in faint breathings amongst us, and the alumni, failing to cherish a college pride whilst here, will not be accompanied by a sterling affection for their Alma Mater when they leave its walls. Our debating societies indirectly prostrated, the taste for classical literature win be diminished; cold science and scholastic plodding will then gloom this proud fabric of the American Sage, and a meagre sheepskin be held up as the sole incentive to intellectual exertion.

"The alleged causes of this proscription of liberal and improving exercises are few, and, as we conceive, wholly insufficient. If there be any bad effects resulting from the practice let it be remembered that every good has its concomitant evils. The finger of scorn should by no means be pointed at venerated customs because, forsooth, they occasion- 
ally prove disadvantageous; neither should the harper hang his lute upon the willow because its music sometimes excites sad feelings."

This complaint appeared in the number for June, I839, and yet there had been anniversary or intermediate celebrations in the Jefferson in 1837 and 1838 , with orations (one of the editors of the Collegian was the orator!), and in the Washington there was no suspension at all. There is probably some explanation of these apparent contradictions. Certainly the board did once prohibit student speeches on public occasions unless the consent of the faculty was first obtained.

The Jefferson, as has been seen, undertook a great deal in the matter of anniversary celebrations, putting into its calendar in 1825 the foundation of the University, the birthdays of Jefferson, Washington, and Patrick Henry, the surrender of Yorktown, and the $4^{\text {th }}$ of July. It soon eliminated all but April I3. Of course the anniversary oration dates from the beginning; but the custom of reading the Declaration of Independence was not introduced until the session of 1846-47. It was probably often omitted. At any rate, there is no record of the observance in $1848,1850,1852,1853,1855,1859-$ not to pass beyond the war.

The names of anniversary or intermediate orators cannot be recovered before $1830-31$, and even after that session there are many gaps in the list. No record can be found for the years 1833,1835 , $1836,1842-45,1854,1856,1858,1866$. Of course there were none to record for the period of the war. The final celebration was not instituted in the Jefferson Society until the session of $1836-37$. Probably the commencement exercises, introduced by the 
professors in July, I829, satisfied for a time all aspirations in that direction. The first program - was entered on the minutes of the faculty in this form :

"The faculty convened in the Rotunda the I8th day of July, I829, where the following exercises took place in the presence of the Rector [James Madison] and Visitors and a numerous assemblage of the public.

"I. The exercises were commenced with an oration by Mr. George P. Beirne of Monroe County, 'On the Happy Influence Which Journals and Reviews Have Exerted by the Conveyance of Intelligence.'

"2. The chairman of the faculty [Dr. Dunglison] mentioned the names of the following students in alphabetical order who at the recent examination had displayed the greatest proficiency in their respective schools. [List.]

"3. Oration by Mr. William F. May of the University, 'On the Connection between Education and Republican Doctrine.'

"4. Essay by Mr. John A. Gretter of Richmond City, 'On the Comparative Advantages of Public and Private Education.'

"5. The chairman next announced that the following students had been admitted by the faculty to graduation in the several schools and classes hereafter mentioned, and delivered to them diplomas: [List.]

"6. Oration by Mr. William Daniel, Jr., of Lynchburg, Virginia, 'On the Causes that Have Retarded the Growth of Poetry in America.'

"7. The exercises concluded with an oration by Mr. Charles Mosby of Powhatan, 'On the Influence 
of, Republican Institutions upon Intellectual Improvement.' "'

The list of the final orators is not quite complete. There is no existing evidence of appointments for the years $1840,1842, \mathrm{I} 843, \mathrm{I} 846, \mathrm{I} 848, \mathrm{I} 853, \mathrm{I} 855$, I859, $1860 .^{2}$

In I860 Charles D. McCoy of Charlottesville, Henry Lee of Alexandria, Virginia; W. O. Bullock of Lexington, Kentucky, and J. W. H. Porter of Warrington, Florida, acting as a committee of publication, issued a roster of the officers and members of the Washington Literary Society, to which they prefixed a history of its organization and vicissitudes. This catalogue was reissued in 1866, with additions and corrections, by an editorial committee consisting of Chapman Maupin of Charlottesville, James W. Foster of Fauquier County, S. Travers Phillips of Staunton, T. Jefferson Stubbs of Gloucester Court House, and A. Frederick Fleet of King and Queen County, all Virginians. The following extracts from these publications preserve a part of the history of the University:

"In the session of 1831-32 (the eighth session of the University) some fifteen or twenty students met together in the room of one of their number and formed themselves into a club, 'or association for mutual improvement in the Art of Oratory.' To this association they gave the name of Academics' Society, the place of meeting being, after the first few weeks, on the west side of the Lawn, the fourth pavilion from the Rotunda, and at present the residence of Professor [John Staige] Davis. A little later an association of the same character was or-

${ }^{2}$ For the names of the orators and those of the debater medalists, see p. 360 . 
ganized at the present proctor's office, ${ }^{3}$ and went into operation under about as favorable auspices as the Academics. These bodies continued a separate existence, though neither of them a very flourishing one until $1835-36^{4}$, when they resolved to unite and form out of the two one vital organization; this new body they called 'The Washington Society, that its name, recalling the deeds of the illustrious father of American liberty, might animate them with the desire of using the power there attained for the good of their country and the weal of their countrymen.'

"Then and thus the Washington Society originated, and thus did she spread her banner to the breeze. The records show that her history has been an eventful one, her ups and downs many. Several times has her very existence been imperilled by discord, but she has been able, on every such occasion, to slough off the discordant spirits, and has only wrapped closer around her the mantle of brotherly love. She has also had to contend with all the disadvantages usually attendant upon the situation of a younger sister; but such trials have only resulted in the attainment of a vigorous and hardy maturity, and she can now bid defiance to all adversaries.

"The minutes and almost everything in the shape of records for the first eight years have unfortunately been lost. Enough, however, has been preserved to show that until 1846 the society was but poorly supported. This was no doubt in great part the result of the want of a hall that it could strictly call its own, for until this date the place of meeting

${ }^{3}$ The present Alumni Hall, East Range.

${ }^{4}$ The revisers of 1866 discovered that the true date of the foundation was 1834-35, and even made an incomplete list of the members of that session. 
had been the proctor's office, which, of course, lacked most of the conveniences afforded by a permanent hall. * * * But the establishment of the Washington Society upon its present firm footing took place in $1845-46$ and was due principally to the efforts of two gentlemen, N. H. Massie and John L. Cochran, esq. * * * Though they are not the real founders of the society, to them it may be said it owes its present existence and flourishing condition. Up to this time the meetings seem to have been suspended about the middle of each session, but in the latter part of $1844-45$ a room which formed a part of the present hall was permanently secured and 1845 constituted a new era in the society's annals. The constitution was then carefully and thoroughly revised, and many cumbrous features remedied, and each succeeding year, consequently, exhibits marked progress. From the earliest formation of the society it had been the custom to elect an orator, and a reader of Washington's Farewell Address, for the 22d of February; but the first notice of a public anniversary celebration occurs in $1846-47$. In the same session was instituted the valedictory celebration. Both of these were held in the Chapel of the University, and printed invitations were then sent to the ladies, only, of the neighborhood. As an additional evidence of her growing prosperity, it may be noted that in the next session the society ordered to be worn a badge, in the form of a plain gold pin, bearing the name of the society, and a representation of waves, with the motto: 'Quam fluctus diversi, quam mare conjuncti.' During the last session ( $1859-60$ ), however, the size and shape of the pin was altered, and Washington's coat-of-arms added. The badge for all public occa- 
sions is a bow of plain white ribbon, worn on the left lapel of the coat.

"In I848-49 the Washington Society made the initiatory move in getting up a periodical called the Jefferson Monument Magazine, the proceeds of which were to be appropriated to the erection of a monument to the memory of Thomas Jefferson. It was conducted by a corps of seven editors, ${ }^{5}$ two from each of the three literary societies, and one from the students at large. The enterprise was at first warmly seconded by the other societies; but the 'proceeds' not coming up to their expectations, they soon became disheartened, and in 185I-52 abandoned it altogether. Other attempts to establish a magazine have, at various times been made by the societies of the University, but with no better success, until 1856-57, when the University Literary Magazine (name since changed to Virginia University Magazine) was founded so securely that it cannot but succeed.

"In I849 a number of members withdrew, and together with deserters from the Jefferson, formed the 'Philomathean Society.' This association was short lived. In I 852 a much more serious revolt occurred and one which well-nigh proved fatal to our body. In that year the 'Parthenon Society' was formed exclusively by members deserting from our own, and this desertion was caused by the failure to elect as final orator the candidate of a party in the minority who, however, refused to join his too ardent supporters, and was afterward a prominent member of our own aśsociation. On this occasion about one-third of the members joined the new

${ }^{5}$ Four, according to the prospectus of the magazine. 
body. But 'whom the gods love die young,' and the Parthenon Society ceased November, I853.

"In $1854-55$ it was found necessary, owing to the large number of new members, to enlarge the hall to its present size. 'I was in the society at the time,' says a former president to whom we are indebted for a number of the facts here given, 'and well remember the feelings of pleasure and anxiety depicted upon the countenances of the old members as, on each Saturday night, we initiated, in the business language of the treasurer, fifteen, twenty, forty and fifty dollars' worth-pleasure at the growing prosperity of the body they loved so well, and anxiety lest the expectant novitiates might not find seats.'

"In the session of 186I-62 a few old members of the Washington and Jefferson Societies united and formed the University Literary Society, and held their meetings in the hall of the Washington. This new body ceased to exist after the close of that session, but in the succeeding session the Jefferson Society was reorganized and continued to hold its meetings thereafter with but few interruptions during the war."

In the Washington the intermediate and final presidency were coveted for the same reasons that made the terms attractive to the ambitious of the Jefferson. The oratorship and the post of reader were also valued honors.

On the $22 \mathrm{~d}$ of February, I838, Washington's farewell was first read at an "intermediate celebration," nine years before the Jefferson made the Declaration of Independence a part of its anniversary program. If the records are to be trusted, the reading was omitted for the years $1839-45$ inclusive, 
after which no break in the custom occurred until everything was suspended for war. In the list of intermediate orators about the same gap appearsfrom 1839 to 1846 inclusive. Thereafter no break occurs until I $86 \mathrm{I}-65$.

The line of final orators is broken during the period of $184 \mathrm{I}-45$ inclusive. Perhaps this uniform suspension of the public exercises of the societies which the lack of data as to the actors usual in such functions seems to indicate was due to temporary low vitality, although the time includes the prosperous years of the Collegian, the first periodical established by the societies. The valedictorians otherwise show full ranks. ${ }^{6}$

The Washington possesses one volume of decided interest-the minute-book beginning in 1859 and continuing the record of the society for some years after the war. Its brief entries in the late winter and early spring months of $186 \mathrm{I}$ are in the spirit of coming war. These young men had all drilled in the Sons of Liberty or the Southern Guard before entering their literary hall to deliberate and debate. Their subjects were significant of the times, and the manner of their decision was unquestionably determined by the peculiar conditions which swayed all judgments. In February the subject for debate was, "Would free trade be adverse to the interest of the border slave States in a Southern confederacy?" The society decided that it would.

Again: "Do the interests of the Confederate States require the imposition of further political disabilities on foreigners than now in the United

${ }^{6}$ For lists of final presidents, intermediate and final orators, debaters, etc., see p. 363 . 


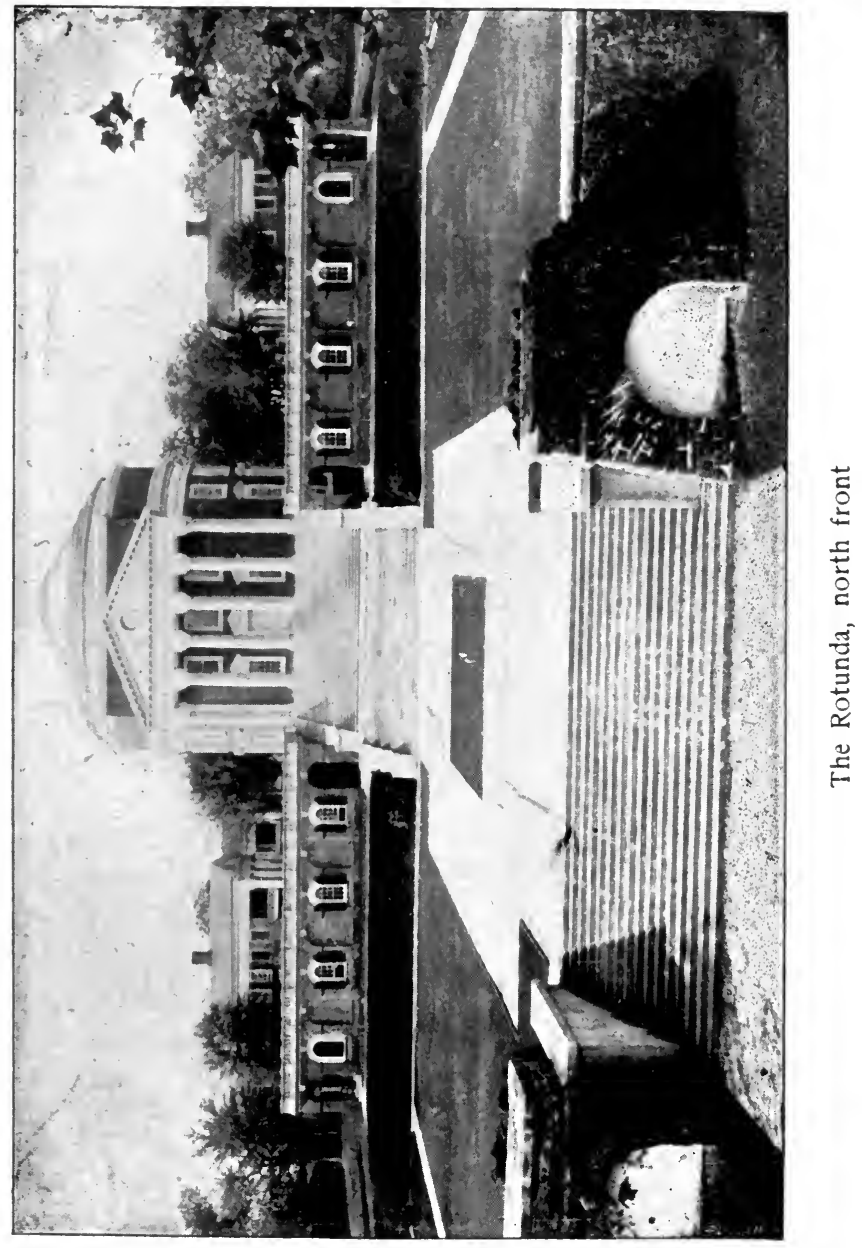

$\circ$
$\stackrel{B}{N}$
$a$
$w$
$\frac{1}{n}$
$\vdots$
$\vdots$
$\vdots$
0 


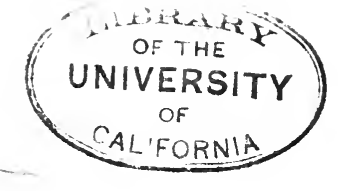


States?" They did, in the opinion of all but three members.

And the last debate before the storm broke was on the subject, "Is slavery the only substantial basis of a republic?" Of course this was decided in the affirmative, although five did vote no. Thus in advance of the Ordinance of Secesssion these young men were considering some of the economic questions that would confront the Southern Confederacy, serene in their confident expectation that the young nation then foretold would be established beyond any possibility of decline or fall.

This was in mid-March. The minutes showed the temperature rising rapidly. This entry appears under the date of I86r: "Mr. A. W. Weddell [of Petersburg, afterwards rector of St. John's Church, Richmond] moved that in view of the stirring and exciting circumstances by which we are surrounded, and the warlike appearances of [our] country which would naturally interrupt the proceedings of all literary bodies, the Washington Society meet again only by order of the president after the adjournment of this meeting." This was just a week after the battalion drill on the Lawn in celebration of Jefferson's birthday when the news of the evacuation of Fort Sumter was announced.

On April 25, I86I, on motion of R. C. M. Page, the final celebration of the society was dispensed with "in view of the probable suspension of lectures at the University growing out of the disturbed condition of political affairs." Subsequently, in joint session the Washington and Jefferson revoked an invitation to "an individual" named David Paul Brown of Philadelphia, who had been selected as orator on the occasion of the joint celebration on the 
coming 4th of July. Evidently David Paul Brown was ugly about it, for this minute appears as a description of the action taken by the joint assembly of the societies upon the correspondence: "Mr. Brown was deemed to have offered a great indignity to the body, and the committee [was] instructed to forward to him a letter which, upon being read before the body, was deemed expressive of their views with regard to the matter." Doubtless.

We come upon another indication of the temper of the times. In I859 Edward Everett had come down from New England and delivered a striking lecture, the proceeds of which he turned over to the literary societies of the University with the expressed hope that the interest would be used in providing a medal to be bestowed upon the writer of the best article on American biography published in the University Magazine. Of course the societies disdained Mr. Everett's medal after learning his pronounced sentiments; Mr. Pendleton moved to abolish it forever, and the motion was carried unanimously. Then $\mathrm{Mr}$. Falligant moved to return the fund to Mr. Everett. Mr. Underwood proposed to appropriate it to the defense of the State and this substitute was adopted. At a subsequent convention of the societies this disposition of the fund was reconsidered, and various suggestions made, such as that it be placed in the hands of the Governor of Virginia to be returned to Mr. Everett at the close of the war, that it be given to the poorest worthy lady of Albemarle, and that the stock in which the fund was invested be transferred to Mr. Everett. Finally it was decided to deposit the money with the proctor to be returned to the donor as soon as the state of the country would permit. 
This minute appears under the date of May 4, I86r : "Mr. Harris, acting upon one of the considerations which led to the suspension of the final celebration for this year, moved that the surplus funds remaining in the treasury after the payment of our debts, be placed in the hands of the Governor of Virginia for the defense of the South in the present war with the United States. The motion was carried unanimously."

The following page of the minute-book contains the one word writ large-INTERREGNUM. The next begins the record of the post-bellum era. Under date of October I4, I865, appears this entry: "After a suspension of four and a half years occasioned by the late war between the Northern and Southern sections of the country, four old members of the Washington Society-Messrs. John H. Lewis, J. S. Harnsberger, W. M. Perkins, and A. F. Fleet, all of Virginia - met in their hall for the reorganization of their society. Mr. Lewis was called to the chair and Mr. Fleet requested to act as secretary pro tem. Upon taking the chair Mr. Lewis made a few touching remarks, alluding to the small number of old members present, and paying a tribute to those who had fallen in defense of their country."

\footnotetext{
${ }^{7}$ Afterwards ascertained to be $\$ 200$.
} 


\section{CHAP'TER XIX}

\section{UNIVERSITY PUBLICATIONS}

\section{VIRGINIA LITERARY MUSEUM-PROFESSORS DUNGLISON AND TUCKER AS EDITORS-STUDENT PUBLICATIONS-Colle- gian, University Magazine, Jefferson Monument Maga- zine, College Topics, Corks and Curls, Annals of Mathe- matics, Alumni Bulletin, \&c.-NOTES OF SUCCESS AND FAILURE.}

In June, I828, Professors Tucker and Dunglison began the publication of the Virginia Literary Museum and Journal of Belles-letters, Arts, etc., in weekly numbers of sixteen pages super royal octavo. They relied upon their fellow members of the faculty to contribute quite freely on the subjects of their special investigations, but it turned out, of course, that the editors (whose names do not appear anywhere in the publication) had to furnish most of the articles they printed. They edited alternate numbers and the single volume of more than 800 large pages which has come under the observation of the writer contains contributions on many subjects connected with the moral and physical sciences and belles lettres, all of them apparently timely and many of them excellent in treatment and finish. Professor Bonnycastle's contributions appear under the signature of $\mathrm{PZ}$ and Dr. Patterson's under that of Trevor. Only two volumes appeared.

The next publication was by the students, and was called the Collegian. It was established in 1838 and lived through four sessions, with a separate editorial committee for each session. For the first the editors were John S. Barbour of Culpeper, afterwards 
a United States Senator from Virginia; John Critcher of Westmoreland County; a political leader in his section and its representative in Congress; $\mathrm{R}$. Barnes Gooch of Richmond, who, although he died young, had won distinction at the bar; James P. Holcombe of Lynchburg, professor of law in this University, a member of the Secession Convention and of the Confederate Congress, and also a confidential agent of the Confederate Government; Thomas H. Watts of Alabama, Attorney-General in President Davis' Cabinet, Governor of his State, and for years the supreme leader of his section. Subsequent editors were-session of $1839-40$ : W. C. Carrington, J. Harvey French, Augustus E. Maxwell, James McDowell, Jr., and Thomas Slaughter; session of $1840-4 \mathrm{I}$ : L. M. Ayer, J. S. Caskie, J. L. Marye, T. R. Rives, and R. E. Withers. The editors for the session of $184 \mathrm{I}-42$ are not named in the magazine, and there is no contemporary reference to them.

At the beginning the Collegian flourished, ending its first year with all its debts paid and a surplus in its treasury. This condition of things led the editors to dream dreams and see visions which were never realized. "Successfully managed," they wrote, "this fund may be yearly increased until it becomes sufficient to support a professorship of English literature which it is proposed shall be established in the University. Thus a most useful purpose might be accomplished, and a great and lasting benefit conferred on education in the State. We throw out this suggestion for the consideration of those who are interested in the success of the Collegian, in that of the University and in the literary 
reputation of Virginia-believing that their interests are one and the same." But the novelty wore off, enthusiasm waned instead of waxing, and the end of the session I842 saw the end of the Collegian also.

Its successor was The University Magazine, whose first number was dated January, I849. This periodical, which seems to end with the May number, which was the fifth, is not to be confused with the University Literary Magazine, established in 1856 , which is still published under the somewhat changed name of Virginia University Magazine. The editors in the first number of The University Magazine-the one of 1849-seemed to regard it as a revival of The Collegian, which had ceased to be seven years before. Its editorial management was certainly quite as good, and this is not an equivocal compliment. Who the editors of the first numbers were cannot be learned from the publication itself. In the April number a new board of editors made its debut. There were seven members: George Mason, on the part of the students; Nicholas Davis, Jr., and F. W. Page, on the part of the Jefferson, V. G. Claytor and J. W. Archer, representing the Washington; and E. F. Paxton and C. E. Sinclair from the Philomathean Society.

The last number of this monthly contained the prospectus of the Jefferson Monument Magazine, whose first number appeared in October, I849. The reason for its establishment was, as its prospectus announced, the desire of the students to testify their gratitude to Thomas Jefferson as the patriot, the statesman, the sage, and especially as the illustrious father of the institution with which they were so proud to be connected. It was the expectation that 
the surplus income of the magazine would form a fund out of which could be erected a monument to "he founder's memory. "In thus proposing to publish a magazine," to quote the prospectus, "the profits of which shall constitute a monument fund, there has seemed to be appropriateness in such an idea of raising the fund by means of the productions of minds which receive their development and training at the institution which was the pride of $\mathrm{Mr}$. Jefferson's heart, the loved child of his old age."

The publication was directed by four editors during the first session and presumably by the same number in subsequent years. Who these editors were there is nowhere the slightest intimation. Excepting two numbers, there are two volumes of the inagazine in the University Library, the last number of the second volume bearing the date of June, $185 \mathrm{r}$. The editorial pages contain no intimation that the publication is to be discontinued, although there is a note of discontent on account of lack of "subscriptions" as well as of contributions.

The University Literary Magazine was established by the Jefferson, the Washington and the Columbian literary societies, with editors from each. The Columbian, however, did not long survive. The first number bears the date December, 1856 , and the first volume ends with the date December, 1857. Since then the volumes have ended with the number for June. Like its three predecessors, the magazine was founded with the avowed purpose of supplying the lack of instruction in composition. There was not at that time, and indeed not for many years, a distinct School of Literature in the University. One is struck by the excellent work done by the student contributors to those early publications. 
Thc editors were soon face to face with the problem which had defeated their predecessors of The Collegian, The University Magazine and the Jefferson Monument Magazine. There were few contributors and they found it difficult to fill with creditable productions the thirty-two pages required for each monthly issue. They hit upon the usual plan for stimulating literary activity. In June, I857, the editors made this anouncement:

"It has been determined by a consultation of committees from the three literary societies of the University to offer a medal of the value of one hundred dollars to be awarded to the writer of the best essay to be published in the Magazine during the next session. The design is, after the nine numbers have been issued, to place them in the hands of three learned professors of the University-Professors J. B. Minor, W. H. McGuffey, and G. F. Holmesand get them to decide as to the respective merits of the articles and award the medal to the most worthy.

"This is, it has been thought, to be a means at least by which the Magazine may be made a real index to the talent of the University, as the honor of such an award will awake the ambitious energies of all. We, therefore, feel safe in promising to our subscribers and friends outside of the University, for the next session, a punctual delivery of a magazine at any rate superior to the one which has been so far issued."

This medal remains to this day an eagerly sought honor. In after years other honors were added, among them a medal for the best translation; an- 
other for the best original verse; and a third for the best short story. ${ }^{1}$

There have appeared two volumes of reprints from this magazine. The first was made of poems under the title of "Arcade Echoes," now in its second edition. It was compiled by the late Thomas Longstreet Wood of Virginia, one of the brightest and most promising men sent out from this institution, but whose performance had not reached the full measure which would have been his at the maturity of his powers, when death claimed him as a youthful victim. The second edition appeared with all the advantage of careful editing and discriminating additions by Mr. John W. Fishburne of Charlottesville. Dr. Charles W. Kent edited the volume of short stories, six in number, under the title of "Idylls of the Lawn," and was probably successfulthrough the exercise of judgment and taste rarely trained-in selecting the six entitled to outrank all other short stories in this publication. The illustrator of this handsome volume was Mr. Duncan Smith, a Virginian artist resident in New York.

In the early winter of I889, Leigh R. Page of Richmond, A. C. Carson, of Riverton, Virginia, and Stuart-Menteth Beard united in advocating the establishment of a weekly paper for the chronicling of athletic news, as well as the other happenings in which students were interested. The societies were approached, but feared that the publication would not be financially successful. After some delay the students above named, and two others-Hunt Chipley of Florida, and John G. Tilton of Virginia-undertook the publication as a private enterprise, and in January, 1890, the first number of College Topics

${ }^{1}$ For a list of magazine medalists see page 368 . 
made its appearance. It at once won favor with the students, and became the organ and exponent of all their enterprises. The literary field was left to the Magazine, but that of college news was monopolized by Topics. Chipley and Page soon resigned, and Joseph McElroy and J. Breckinridge Robertson took their places-the latter as editor-in-chief. At the close of the first volume these adventurers in the field of college journalism divided among themselves a surplus of \$150. The General Athletic Association, which had been organized in 1887 , acquired Topics in some way at the beginning of the session of I890-9I, and since that time it has been managed in the interests of athletics. Its editors are appointed by the Association.

The students' annual, Corks and Curls, preceded Topics some two years, the first number appearing in I888. It is published about May of each year by a board of editors and artists appointed by the Greek-letter fraternities, and appears in quarto size. In addition to the usual contents of a university "annual" it has printed a great many articles of high excellence and some descriptive papers of rare finish.

More than half a century separates the first publishing venture of the faculty and the next, which was the Annals of Mathematics, established by Professor Ormond Stone, in 1884, as a medium for the publication of advanced investigations. For a time Professor Echols was associated with him as editor. In I899 Harvard College acquired this highly creditable publication.

The Alumni Bulletin dates from I894, when its publication was begun by the faculty to provide a means of communication between the University and its alumni. Itș first form was quarto, but in 
190I it was changed to royal octavo. A great deal of the history of the University, dating years before this publication was established, has been recovered and given place in its pages; while, of course, every important event occurring after its publication was begun has been duly recorded. 


\section{CHAPTER XX}

THE GENERAL IIBRARY.

Jefferson's Early Plans and Performances-His CataLOGUE AND VIEWS UPON WHICH IT WAS BASED-HIS BOoKs-GrFTs of MONEY AND Books-RotundA AND Litbrary Destroyed by FirE-STATUARY, Paintings, and OTher Treasures-Notable Gatherings-BanQUET TO LAFAYETTE-JEFFERSON'S RESPONSE TO A TOAST.

Mr. Jefferson made early and liberal provision for a library as an important part of the University. It was to occupy the noblest room in the most imposing edifice among his buildings, and he saw to it that the selections for its shelves were made on a plan carefully thought out. When Gilmer went abroad to engage professors he had at command a liberal sum to be expended for the proposed collection, and the pressure of other needs for money was never strong enough to give the library a secondary place in Mr. Jefferson's plans.

It may be doubted whether any University or other library in this country was planned with so wise an understanding of its purposes as Mr. Jefferson's catalogue, made in 1825, displays. Its opening pages are an essay on classification, but its authority has not controlled the librarians of the University. It was too elaborate for a small beginning, and the arrangement exhibited in the catalogue printed in 1828 was very different and for a small library far more serviceable as a working plan. There were twenty-nine chapters, each representing a group of books, thus: I. Ancient languages; 2. Modern history; 3. Modern geog- 
raphy; 4. Modern philology and literature; 5 . Mathematics and natural philosophy; 6-9. Natural history, agriculture, botany, zoology; ro. Mineralogy and geology; II. Chemistry; I2-22. Medical topics; 23. Mental philosophy and ethics; 24. Political economy; 25. Politics; 26. Law; 27. Religion and ecclesiastical history; 28. Architecture, etc.; 29. Poetry, rhetoric, education, etc.

This classification was followed for seventy-five years. Modern methods have since been introduced.

$\mathrm{Mr}$. Jefferson's catalogue is of rare interest to bibliothecaires. The general title of the manuscript volume is "A Catalogue forming the Body of a Library for the University of Virginia, to be afterwards enlarged by annual additions: An explanation of the views on which this catalogue has been prepared." And these are the views-

"I. Great standard works of established reputation, too voluminous and too expensive for private libraries, should have a place in every public library, for the free resort of individuals.

"2. Not merely the best books in their respective branches of science should be selected, but such also as were deemed good in their day, and which consequently furnish a history of the advance of the science.

"3. The opera omnia of writers on various subjects are sometimes placed in that chapter of this catalogue to which their principal work belongs, and sometimes referred to the Polygraphical chapter.

"4. In some cases, besides the opera omnia, a detached tract has been also placed in its proper chapter, on account of editorial or other merit. 
"5. Books in very rare languages are considered here as specimens of language only, and are placed in the chapter of Philology, without regard to their subject.

" 6 . Of the classical authors, several editions are often set down on account of some peculiar merit in each.

"7. Translations are occasionally noted, on account of their peculiar merit or of difficulties of their originals.

"8. Indifferent books are sometimes inserted, because none good are known on the same subject.

"9. Nothing of mere amusement should lumber a public library.

"IO. The 8vo form is generally preferred, for the convenience with which it is handled, and the compactness and symmetry of arrangement on the shelves of the library.

"II. Some chapters are defective for the want of a more familiar knowledge of their subject in the compiler, others from schisms in the science they relate to. In Medicine, e. g., the changes of theory which have successively prevailed, from the age of Hippocrates to the present day, have produced distinct schools, acting on different hypotheses and headed by respected names, such as Stahl, Boerhaave, Sydenham, Hoffman, Cullen, and our own good Dr. Rush, whose depletive and mercurial systems have formed a school, or perhaps revived that which arose on Harvey's discovery of the circulation of the blood. In Religion, divided as it is into multifarious creeds, differing in their bases, and more or less in their superstructure, such moral works have been chiefly selected as may be approved by all, omitting what is controversial and merely 
sectarian. Metaphysics have been incorporated with Ethics, and little extension given to them. For, while some attention may be usefully bestowed on the operations of thought, prolonged investigations of a faculty unamenable to the test of our senses, is an expense of time too unprofitable to be worthy of indulgence. Geology, too, has been merged in Mineralogy, which may properly embrace what is useful in this science, that is to say, a knowledge of the general stratification, collocation and sequence of the different species of rocks and other mineral substances, while it takes no cognisance of theories for the self-generation of the universe, or the particular revolutions of our own globe by the agency of water, fire, or other agent, subordinate to the fiat of the Creator." 


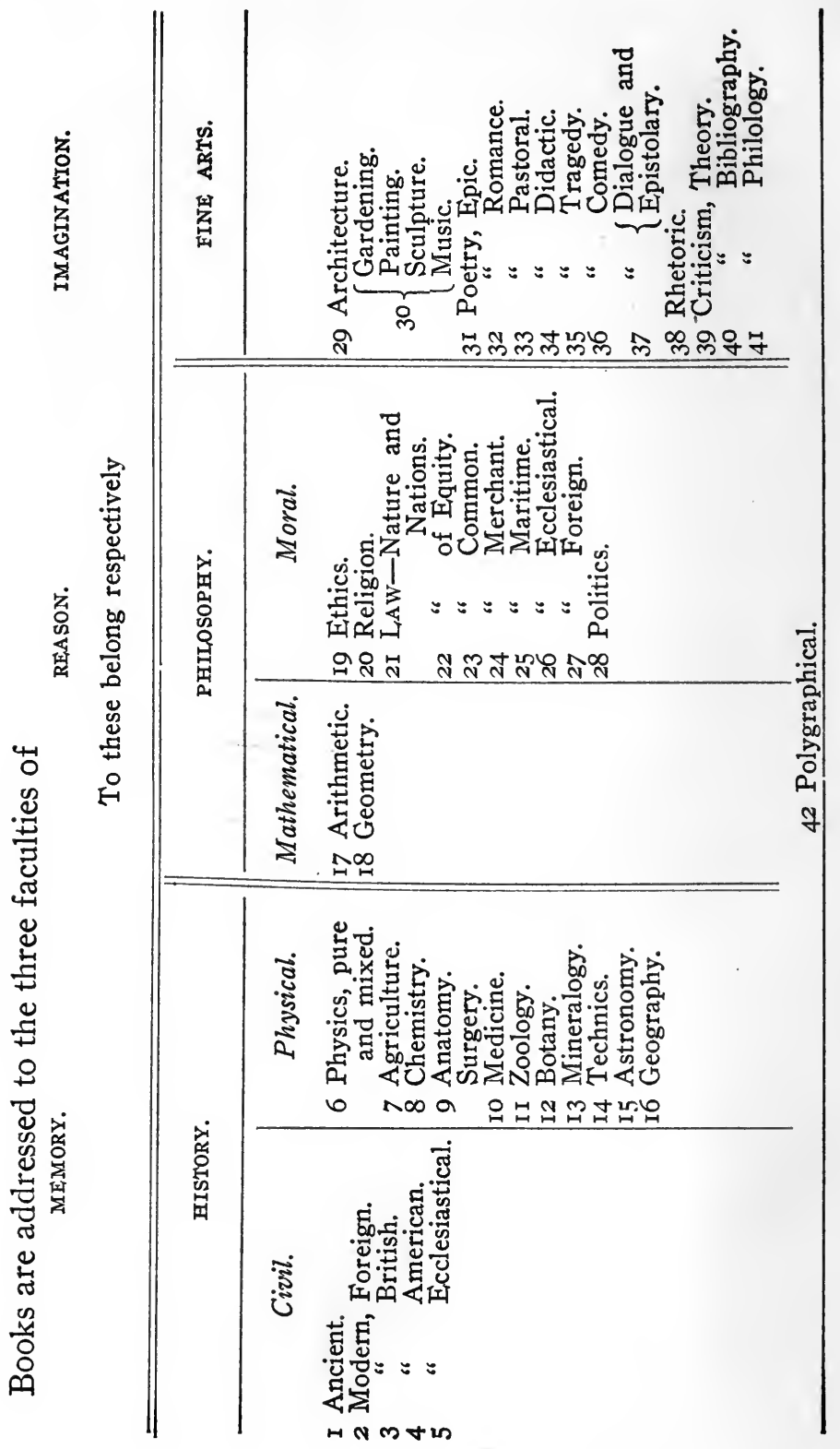


In this tabulation the numbers indicate the division into chapters, of which there are forty-two, representing as many groupings of the books. The 6,860 volumes named in the catalogue were estimated to cost $\$ 24,076.50$ (more than $\$ 3.50$ each), and the most of them were probably purchased. The proctor's report a year later (September 30, I826), proves the payment of $\$ 35,947.38$ on "account of library and apparatus." The apparatus, doubtless, was for the schools of chemistry and natural philosophy.

The books were first shelved in a room in Pavilion VII, the fourth from the Rotunda on West Lawn, and remained there until after Mr. Jefferson's death. The handsome hall in the Rotunda was nearly finished by October, 1826 , and by the 7 th of that month the books were put into it.

The larger part of Mr. Jefferson's library was sold to Congress for $\$ 23,950$, much less than it had cost. The remainder he devised to the University and expressed a wish that his bust by Caracchi with its pedestal and truncated column should go with it. His executor, his grandson, Col. Thomas Jefferson Randolph, addressed to the Visitors this explanation:

"It has been my most earnest desire to comply with all his wishes, and particularly with this; but the deeply embarrassed state in which his affairs were left renders it extremely doubtful whether his property will be sufficient to meet claims upon it of a higher dignity. Under these circumstances, my duty as executor compels me to withhold the payment of legacies until the debts are discharged.

"The breaking up his establishment, the sale of his effects and the dispersion of his famliy will leave 
the library exposed to injury. I must, therefore, ask to be allowed to deposit it at the University, in charge of your librarian, subject to my future order, should it become necessary to expose it to sale for the discharge of claims of a superior nature. The bust, not being mentioned in the will, but being the subject of an informal direction to his executor, cannot be deemed a specific legacy; and, deeply mortifying as it is, he is compelled to offer it for sale with the residue of his property in discharge of claims upon it.

"Feelings of the most affectionate devotion to my grandfather's memory would induce me, as his executor, to fulfil his wishes upon these points at all risks but that of injustice to his creditors and the fear that his memory might be stained with the reproach of a failure to comply with any of his engagements. An assurance is, therefore, given that when his debts are discharged, however much his family may be straitened in their circumstances, no considerations of pecuniary interest or of their individual distress will bar immediate compliance."

The story of how Colonel Randolph assumed all debts not discharged by the sale of the estate, and paid them to the last dollar, is well known and need not be repeated. Unhappily, the books and the bust were lost to the University, and the only volumes of his that reached the library were given in his lifetime, with the single exception of D. Justiniani, Sacratissimi Principis, Institutionum, sive Elementorum, an Elzevir dated I679, with the autograph of "Richd Baldwin, E Coll. D. Jo. Bap. I687." The books he personally "transferred were volume 2, new series, of the American Philosophical Transactions, Josse's Spanish Grammar, which was 
soon lost, Sale's Spanish Hive, and Charles Kelsall's Phantasm of an University.

Previous to the civil war the Board of Visitors made liberal provision each year, but since $\mathrm{I} 860$ the annual income available for the purchase of books has been wholly inadequate, and if it had not been for the liberality of friends of the institution the library would be sadly deficient.

The first gift was from Mr. Bernard Carter in 1826. It consisted of a small but relatively valuable collection of books. Mr. Christian Bohn, of Richmond, a brother of the London publisher, bequeathed books valued at about $\$ 500$. They were largely German periodicals and became available in 1840 .

Mr. Madison bequeathed his library to the University, but long years elapsed before it was transferred from Montpelier, and in the interim many of the books were lost or otherwise rendered unavailable. In the end some two thousand volumes were placed on the shelves of the library.

Mr. Madison also gave \$1,500, which, merged with the gift of Mr. Douglas $\mathrm{H}$. Gordon, of Baltimore (1883), constitutes the Madison and Gordon fund, the only source of income from a permanent endowment fund available for the general purposes of the library.

In the twenty years beginning with 1865 the most considerable gift to the library was by Arthur W. Austin, of Dedham, Massachusetts, 'whose books, amounting to 5,000 volumes, especially valuable for works on Southern literature, were willed to the University and became available in $\mathrm{I} 884$. Other gifts in this period were $\$ 5,000$ from the generous friend of the University, W. W. Corcoran of 
Washington; \$I,00o from Mr. A. A. Low of Brooklyn, New York; \$500 from Mr. Robert $\mathrm{H}$. Gordon, a Scotch gentleman residing in New York city, who had greatly enjoyed a visit to the University, and some other smaller donations. Between I885 and I895 there were many gifts of books.

The great fire in the fall of the latter year reduced the library from 56,733 volumes to 17,194 , of which 5,000 were law books. The books that were saved were all on the first floor. In the upper gallery were those of the Bohn collection, the Madison gift and the Austin bequest, and others acquired from various sources. All were lost except three or four Austin books which were probably out of the library at the time of the fire. In the middle gallery were the medical books, the Madison pamphlets, the files of literary reviews, and scientific publications, including the Monumenta Germanica, a collection of considerable value-all lost, except some of the pamphlets.

While the library probably contains more books now than before the fire, the loss has been repaired only in part. A pressing need is an endowment of at least $\$ 50,000$, with no restraining conditions as to the expenditure of the income beyond the provision that it shall not be diverted. With such an income at command the symmetry of the collection could in some years be much improved by the filling-in of unfortunate gaps inevitable in a library constituted in large measure of private ones of great individual worth but not strictly complementary of each other nor forming a whole as catholic as the bibliothecal needs of a university.

Immediately after the fire the work of rehabilitation was begun. At about that time the classical 
library of the learned Dr. Martin Hertz, of the University of Breslau, collected during his active career as student, docent and lecturer covering some sixty years, was in reach-a fact known to Dr. Thomas R. Price, then a professor at Columbia University in New York, but formerly student and professor in the University of Virginia. Dr. Price leading, the New York Alumni acquired the collection of books and pamphlets, some 12,000 valuable volumes, and forwarded it to the University. ${ }^{1}$

Former Governor Frederick W. M. Holliday of Winchester, by will, left his fine library to the University. It consisted of nearly five thousand volumes, covering the field of general literature, geography, and travel in a manner far more satisfactory than usual in private libraries of like size. The books reached the University in 1899 , and occupy specially prepared cases in the first gallery.

In the same year the valuable library of Professor George Frederick Holmes was acquired by purchase. It is rich in classical literature, and nearly every volume of the 3,000 has been made more than intrinsically valuable by annotation at the hands of the great scholar. Nothing seemed to be beyond the range of his scholarship or the powers of his intellect.

A short time after the death of Professor Thomas Randolph Price steps were taken by friends of the University to acquire that scholar's very valuable private library, but his widow and daughter put an

\footnotetext{
${ }^{1}$ For an interesting article on this collection and its acquisition, written by Dr. James A. Harrison in his always attractive style, see Alumni Bulletin, Vol. IV, page 8.
} 
end to it at once by offering the books to the University as a gift. This collection makes very desirable additions to the library's resources in works on philology, belles lettres, and biography.

The Shipp library, chiefly books on travel and the early history of America, reached the University in December, 1903. They were 5,000 in number, and were the gift of the recluse scholar and author, Barnard Shipp, who died in 1904 at an advanced age. Mr. Shipp was a native of Mississippi, and there he died, but he had spent many years of his life in Louisville, where his library was collected.

From scores of sources small collections have reached the University since the fire. Mr. Ballard Bruce's books were given by his daughter, Dr. Bruner's modern language library was purchased, Dr. James Bolton's medical collection came to the University through his son, Major Channing M. Bolton, while every year a large number of volumes, valuable for their contents and valuable by reason of their excellent manufacture, reach the library from the Rev. Hazlett McKim, a native of Maryland resident in New York.

Immediately after the destruction of the library books were tendered the University in generous numbers by the leading publishers of this country and by several American universities and colleges, and by Oxford and Cambridge in England. The promptness of this giving made the benefactions of double value.

Mrs. Margaret Paul, widow of D'Arcy Paul of Baltimore, has contributed $\$ I, 000$ which has been used as a nucleus of a fund to provide periodicals in the field of modern languages, while the estate of Alfred H. Byrd, who died in I899, amounting to 
$\$ 10,000$, was given to the University to establish a fund for the purchase of Virginiana. A very valuable collection is being gradually assembledthe most recent acquisition being the Virginiana attached to the estate of the late Joseph A. Johnston of Richmond, Virginia.

Two handsome cabinets of dark wood, valuable in themselves and for their contents, were given by Dr. and Mrs. James A. Harrison; one contains an autographed collection of books by Southern authors, and the other a number of editions of Poe's works and Poe literature. A third cabinet, also of rich wood and fine workmanship, is the gift of Mr. John L. Williams of Richmond. It is filled with works of his selection-all of them standard, and from the best editions.

Besides its books the University has placed other of its treasures in the Rotunda. In I854 the legislature of Virginia appropriated \$10,000, and later added $\$ 500$, for a life-size figure of Jefferson in marble. Alexander Galt, a young sculptor of Norfolk, Virginia, was engaged, and the figure and pedestal reached the University at the beginning of the civil war, but was not unveiled until June, I868, when the Hon. Hugh Blair Grigsby made the address. Mr. Galt had died in the mean time. The statue occupies a commanding position in the library. Near it is the bust of Poe, in bronze, by George Julian Zolnay, the Hungarian sculptor. It is an idealized likeness of the poet, the features expressing strikingly the gloom of the sensitive soul of the author of the Raven. Few visitors leave the University without seeing this memorial of its chief poet. The bust was provided by the Poe Memorial Association, which 
was composed of students and several professors, and was unveiled on the 7 th of October, I899, the fiftieth anniversary of Poe's death. ${ }^{2}$ There are four other busts, among them a marble one of Professor Minor, by Valentine, and one of Lafayette in Sevres China, by Houdon, a gift of the French Republic in recognition of the courtesies extended to Ambassador J. J. Jusserand in I904. Among the portraits, probably the most interesting is a small oil of Frances Walker Gilmer, the first law professor. His pale face and lusterless eyes tell the story of failing health as eloquently as the solicitous letters of William Wirt have done. Mrs. Lucy A. Minor willed the portrait to the University, and it was transferred to its care upon her death in I88I.

Many gatherings, banquets, and other "routs" have taken place in the Rotunda, but perhaps the most notable was the dinner to General Lafayette, November 5,1824 . The procession approached the University in this order: Chief marshal with two aids; president of the day; General Lafayette; Mr. Jefferson and Mr. Madison in a landau drawn by four gray horses; the General's son and staff in a carriage with two cream-colored horses; Visitors of the University in a carriage; standing committee, magistrates, cavalry, junior volunteers, citizens on horse-back, citizens on foot. It passed along East Range to the bottom of the Lawn, dismounted, and proceeded on foot to the Rotunda, over which floated three flags-probably those of France, the United States, and Virginia. In replying to an ad-

${ }^{2}$ The Poe Memorial Volume, by Dr. Charles W. Kent, J. P. Bell Company, Lynchburg, publishers, is devoted to this event, and contains an interesting collection of letters of appreciation from the literati of America-a consensus more authoritative than the voices that sometimes guard "halls of fame." 
dress General Lafayette paid Mr. Jefferson a compliment which won the warm approval of the enthusiastic multitude. "Nor do I," he said, in turning a handsome period, "in anything more cordially sympathize with you, than in the mention you have made of the venerable friend, whom, if there was but one university in the world, the enlightened men of both hemispheres would, in common, elect to preside over universal information."

The banquet took place in the upper room of the Rotunda, the table arranged in three concentric circles. Over the place assigned to Lafayette was an arch of laurel supported by two of the columns that sustained the gallery. Valentine W. Southall presided. First on his right sat the guest of the day, then Jefferson and Madison; on his left, George W. Lafayette and his suite. When the cloth was removed regular toasts were proposed to the guest, to Madison and Jefferson, and a great number were volunteered in addition. What proved to be one of the chief sentiments was "Thomas Jefferson and the Declaration of Independence-alike identified with the cause of Liberty." The object of this compliment handed to $\mathrm{Mr}$. Southall the following response, which he read effectively:

"I will avail myself of this occasion, my beloved neighbors and friends, to thank you for the kindness which now, and at all times, I have received at your hands. Born and bred among your fathers, led by their partiality into the line of public life, I labored, in fellowship with them, through the arduous struggle which, freeing us from foreign bondage, established us in the rights of self-government; rights which have blessed ourselves, and will bless, in their sequence, all the nations of the earth. In 
this contest, all did our utmost, and as none could do more, none had pretensions to superior merit.

"I joy, my friends, in your joy, inspired by the visit of this, our ancient and distinguished leader and benefactor. His deeds in the war of independence you have read and heard. They are known to you, and embalmed in your memories, and in the pages of faithful history. His deeds in the peace that followed that war are, perhaps, not known to you, but I can attest them. When I was stationed in his country for the purpose of cementing its friendship with ours, and of advancing our mutual interests, this friend of both was my most powerful auxiliary and advocate. He made our cause his own, as in truth it was that of his native country also. His influence and connections there were great. All doors of all departments were open to him at all times. In truth, I only held the nail, he drove it. Honor him, then, as your benefactor in peace as well as in war.

"My friends, I am old; long in the disuse of making speeches, and without voice to utter them. In this feeble state, the exhausted powers of life leave little within my competence for your service. If with the aid of my younger and abler coadjutors I can still contribute anything to advance the institution within whose walls we are now mingling manifestations to this our guest, it will be, as it has ever been, cheerfully and zealously bestowed. And could I live to see it once enjoy the patronage and cherishment of our public authorities with undivided voice, I should die without a doubt of the future fortunes of my native State, and in the consoling contemplation of the happy influence of this 
institution on its character, its virtue, its prosperity and safety.

"To these effusions for the cradle and land of my birth, I add, for our nation at large, the aspirations of a heart warm with the love of country; whose invocations to heaven for its indissoluble union will be fervent and unremitting while the pulse of life continues to beat, and when that ceases, it will expire in prayers for the eternal duration of its freedom and prosperity."

A contemporary account says that the toast to Lafayette was received with enthusiastic cheering which "rolled in billowy volumes around the spacious hall, and sank in the stillness of enthusiasm;" that when Mr. Jefferson's speech was read, the General was moved to tears; he grasped the hand of the venerable friend who penned it and sobbed aloud. 


\section{CHAPTER XXI}

THE GREAT FIRE OF I895

Sunday Morning Fire Alarm-EFforts to Save the RoTUNDA-REMOVAL OF GALT'S STATUE OF JEFFERSONPROMPt Action of FaculTy aNd Visitors-No SusPENSION OF WORK-MEANS SOON AT COMMAND-RESTORATION AND EXPANSION-LAWN BuILDINGS AND THEIR OCCUPANTS-PROCTOR'S OFFICE AND THE POSTOFFICE.

A few minutes after the first church bells had rung their summons to the morning service on October 27, I895, the bell at the University, and that at the fire department in Charlottesville, sounded an alarm, and word was passed from mouth to mouth that the University was burning. There had been many such rumors, but they had all proved to be false, and this many thought would turn out to be so too. The church-goers in the main assembled in their accustomed places, and remained throughout the service. The flock under the Rev. H. B. Lee alone took the report seriously, and the rector dismissed his people.

Confirmation followed fast, and consternation seized the people in the little city and the University. Throngs overran the grounds, and men, women, and children were soon engaged in an effort to save property.

The little fire company at the University was promptly on hand, but it was helpless. The Charlottesville firemen came and were equally helpless. The water pressure was insufficient to propel a stream on to the burning building, and there was no 
engine. Lynchburg, Staunton, and Richmond were appealed to.

The conflagration originated in the fourth floor of the Annex in a room used by the engineering department. There had been no fire in the furnaces for forty-eight hours, and it is said there were no electric wires in the northwest corner where the flames first appeared. An investigation at the time failed to disclose the source of the disaster, and it is bootless to inquire now.

The Annex was doomed and the prophecy of Colonel Randolph, made at the time of its building, that it would be consumed by fire, and be the cause of the destruction of the Rotunda, seemed, in the first half-hour after the alarm, sure of partial fulfilment. How to make the fulfilment only partial was the problem to which Professor Echols, who led the fire-fighters, devoted himself with the utmost energy. The building in flames was joined to the Rotunda by a porch partly supported by huge columns, and this porch it was feared would be the bridge across which the devouring element would reach the Rotunda. He sent for dynamite and demolished the columns. The roof remained apparently unshaken. The utmost efforts, aided by abundant supplies of dynamite, failed to destroy entirely this connection, although the explosions were so terrific that the windows in the Museum and other nearby buildings were shattered.

In the mean time some of the apparatus housed in the Annex, especially in the department of natural philosophy, were taken to a safe place. Some of the young men had started to remove Balze's copy of "The School of Athens," but a sanguine professor, who could not understand how the 
University could be destroyed, intervened, and the historic canvas was left to the flames.

All this time ladies and gentlemen and active boys were engaged in carrying books from the shelves, and portraits from the walls of the library, whose spacious halls were soon filled with smoke. In this way the portraits of J. E. B. Stuart; the philanthropist W. W. Corcoran; Cabell, Jefferson's able coadjutor, and many others of distinguished connection with the University, were saved, and continue among the treasures of the institution.

Alexander Galt's marble figure of Jefferson scemed the one thing beyond the powers of men to remove unaided by machinery. Nobody would have believed it possible, and yet twenty or thirty students with no other appliances than a rope, a mattress, and a table removed the statue from its pedestal and conveyed it down two flights of circular stairs to the Lawn, and with injuries so slight that the casual observer does not detect them. How was it done? A leader in this band of young men tells the story in this vivid way : ${ }^{1}$

"Over yonder, surrounded by its iron railing with its top spikes curving outward, in the same relative position in which it stands today, was the splendid marble statue of Jefferson by Galt. Remember that in those days it stood on the main floor of the Library, which is now the second gallery.

"Some one, in what some might have termed a rash moment, suggested that the statue should be taken out, as it was on the side of the house next to the fire and so in more imminent danger. No sooner had the suggestion been made than some-

\footnotetext{
${ }^{1}$ Morgan Poitiaux Robinson, Va. Univ. Magazine, November, 1905 .
} 
body produced a rope from somewhere. (As I have said, nobody knew where things came from that day, nor how they happened.)

"Fortunately there was a man in the crowd who knew the value of ropes and knots at a time like that. That man was the present Dr. Howard H. Bailey of Washington, D. C. The boys stood in chairs and lifted the iron railing over the head of the statue and threw it on the floor. Taking the ropes with him, Bailey went up into the then first gallery (the present top gallery) and dropped a noose over the head of the statue; this he pulled taut, passed it around one of the pillars in the gallery and then threw the loose end to the crowd on the floor below. Then with a second rope he did exactly the same thing, except that he did not pass it around a pillar. The first rope was eased out by the crowd on the floor and, as a back-stay rope, held the statue from falling over on its face, while the second rope, as a fore-and-aft stay, enabled the students to pull the statue down into a horizontal position. As soon as it was in a horizontal position, one of the library tables was run under the statuethe pedestal at that time being about the height of the tables (the present pedestal is a new one, as the old one was burned), but instantly the great weight of the marble crushed the table to the floor, and this, too, with no injury to the statue except a minor item, which is today testified to by the chipped off hem of the cloak on the right-hand side-a matter too trifling for more than mere mention when compared with the saving of the statue. Once on the floor, the statue was turned over on its back and with the ropes the boys began to haul it across the library to the door (just inside the window above 
the present main entrance to the library). This door was the only entrance and exit to the library, so it was necessarily crowded with those hurrying out the books, pictures, etc., as the flames were now well in the room, though the ladies, as well as the boys, laughed at the flames and kept on with their work of saving the books, having dipped their handkerchiefs in water and tied them over mouth and nose, while they groped around through the smoke looking for books and pictures.

"The statue had gotten just half in, half out of the Library door and was jammed, as it was a bit long to make an easy turn out to the narrow platform at the head of the staircase, which led down around the curving wall to the present main floor of the Library.

"It was an awful scene. The smoke was so thick and dense that one could not see twenty feet from him; the jingle of glass which was being knocked and kicked out of the book-cases; dozens of men and boys all shouting different things; the crashing of beams accompanying the frequent explosions of dynamite cartridges; the roar of the flames which were now well in the room and cast a dull, red, fiendish glow over everything through the smoke; the crackling of burning timbers; all these things tended to make a veritable hell, when suddenly there was a fearful explosion as though the heavens had been rent asunder. The next moment all was silence; we were in total darkness; the whole earth seemed to tremble; the Rotunda rocked; the voices hushed; the crashing and the crackling of the beams was checked; but only for a moment: 'Great God!' one thought, 'we are lost.' This silence lasted for, and these things happened in less than a moment, 
for in the next, while the Rotunda still rocked, the most awful yells were heard; every pane of glass not already broken had been shattered by the force of the explosion, and with a terrific crash the whole plaster ceiling of the dome of the Rotunda came down to the floor. Every one rushed for the single door, there to find the statue half in, half out of the Library; there was a jam, but the cooler heads quickly dispersed it. The statue was gotten out on the staircase and step by step it was carried down the western stairs, feet foremost. As the base of the statue was eased over each step, it would gather momentum and gaining speed would tear off the top edge of the next step, while under the combined weight of the statue and twenty to thirty of the students, the whole staircase would tremble.

"Safely down the stairs, it was slid along the floor and out on the portico of the Rotunda, where mattresses, taken from near-by rooms of the students, were laid on the marble steps, and the statue was eased down to the Lawn out of the reach of danger, there to be covered with a blanket until a canvas could be procured for the purpose. It is conservatively estimated that it took from ten to fifteen minutes to remove the statue from the Library. Certain it is that it took a gang of workmen with rollers, jacks and blocks, ropes, etc., half a day to remove it from the Lawn to the Museum, where it was temporarily kept."

The appeal to Lynchburg, Staunton, and Richmond met with as ready response as was possible, considering the distance. When the special train from Richmond reached Gordonsville it was stopped by a telegram conveying the information that the Rotunda and Annex were destroyed and the fire 
under control. Staunton sent men and hose; it had no engine, as the elevation of the water supply above that city makes one unnecessary. Lynchburg sent men, hose, an engine, and the visitors from both cities contributed largely to the suppression of the conflagration.

By twelve o'clock, less than two hours from the time that Mr. Foshee, a student, saw the smoke issuing from the Annex, the fire had destroyed that building and the Rotunda, reaching Mr. Jefferson's clock in the pediment of the South portico before the hands had quite reached twelve. The one-story structure uniting the basement of the Rotunda with the East and West sides of the Lawn were in ruins, having been demolished to prevent the spread of fire to the pavilions and dormitories of East and West Lawn. No description can adequately realize the picture of desolation and disaster as it appeared that Sunday afternoon. By the faculty, students, alumni, and all others who through association and sentiment regarded the Rotunda with reverence it was looked upon as a supreme calamity, and the faces of even men were wet with tears.

The men to whom the State had committed the fortunes of the University were not dismayed. The chairman of the faculty had the gifts of a leader and his colleagues were men capable of coping with the emergency. The fire was under control by 2.30 -at 3 the faculty was in session in the chemical lecture-room. Before they adjourned they had decided that not a lecture should be lost and had made out a schedule of places and hours.

Every academic and law lecture-room had been destroyed and so there was a scattering of the schools. Jefferson Hall, the rooms over the post- 
office, and the Museum were utilized, and nine o'clock the next morning found the students assembled and lectures in progress in each of these places. The Washington Hall was assigned to the law department. The temporary office of the chairman, Professor William M. Thornton, was number 5 West Lawn.

No time was lost in vain regrets. The hour was critical and prompt action essential both for immediate needs and for the larger matter of the public relation to the problems the disaster had precipitated. Supineness in the chairman and his colleagues, and a failure of the Visitors to comprehend the full extent of the material loss, would have left the State and country unguided and free to yield to a hopeless resignation. But a wise readiness and co-operation gave convincing proof that the loss was material and not spiritual, and that the University of Virginia was the same and undiminished.

Faculty and Visitors faced the loss without a delusion as to the problems it brought them. The property burned represented an expenditure of a quarter of a million and was worth more. The Rotunda had originally cost $\$ 60,020$; its clock, bell, books, plates, \&c., $\$ 107,330$; the Annex and the School of Athens $\$ 61,839.99$, not to speak of the contents of the several departments housed in it, nor of the gifts to the Library, whose destruction added immensely to the total. The basement rooms, the "old chapel" and the students readingroom, in construction and repairs, would probably add $\$ 10,000$.

The assets available to replace this loss consisted of the walls of the Rotunda, happily uninjured, less than $\$ 50,000$ derived from insurance and some 
other sources, and the good disposition of the State, the alumni, and philanthropic friends. From these sources it was soon seen that rehabilitation and extension would require nearly half a million of dollars. It was a time of faith and works indeed, and in a marvelously brief period plans were agreed upon and contracts entered into for the rebuilding and the additions regarded as absolutely necessary to provide an adequate arena for the constantly expanding life of the University.

In I893 the Fayerweather Gymnasium was erected and equipped out of money from a bequest by Daniel B. Fayerweather of New York. This edifice, complying with the canons of good taste from the architect's point of view, and harmonizing with its surroundings, is distinguished as being the first structure erected at the University after the death of its founder that is at all worthy of the place excepting the Gothic chapel, which, while of a different order of architecture, finds favor for its very beauty. It makes one shudder to think what would have resulted if the Rotunda had been destroyed in I850, or thereabout. Ordinarily, restoration in matters of this kind is but another word for desecration, accomplished through the operation of bad taste or stinginess. Happily, the fire came when the reign of architectural horrors had ended. From that day to this good luck has seemed to attend the institution. Some wise person must have suggested McKim, Meade \& White to the faculty, as the architects for this emergency, and no doubt the same sage made fortunate suggestions to these gentlemen while they were studying the conditions and deciding upon the extent and manner of restoring what had been lost and of extending the original 
plant. The spirit of Jefferson dominated at this crisis, as it has at other crises, in the history of the University.

The Visitors at the first engaged McDonald Brothers, architects of Louisville, Kentucky, under whose direction the Rotunda received a temporary roof for the protection of its walls against weather. The basement wings were rebuilt with fire-proof roofs, and the debris of the destroyed Annex removed. The same firm on January 4, I896, reported general plans to the building committee, which consisted of Dr. W. C. N. Randolph (rector), A. C. Gordon, L. R. Watts, and Daniel Harmon, of the Visitors, with Wm. M. Thornton and W. H. Echols of the faculty. This committee on the I8th of January selected as the architect Mr. Stanford White of the firm of McKim, Meade \& White of New York, McDonald Brothers relinquishing the completion of the designs of the Rotunda to the latter firm.

Mr. White presented alternative plans on March 2 , and the one selected used the site at the foot of the Lawn for the new buildings. It involved the construction of another terrace, 200 by 300 feet, and the erection of five buildings; the Rotunda, the Academic Building, the Physical Laboratory, the Mechanical Laboratory and the boiler house. The further chronology of this undertaking embraces the acceptance of the plans by the Board of Visitors on March I3, the submission of detailed plans to the committee, their modification and adoption on April 16, and the letting of the contracts on May 2. The limit fixed by the Board was the expenditure of $\$ 250,000$.

The Rotunda, already described to some extent, 
was rebuilt as far as its outward form was concerned in accordance with the original plans. This course was in obedience to the fitness of things and in response to a universal sentiment. The capitals remained for some years simple blocks of Carrara marble, for lack of the means to carve them, but the means, about $\$ 8,000$, was provided by Mr. John Skelton Williams of Richmond, in honor of his father, Mr. John L. Williams, a very loyal alumnus, and the work done promptly and satisfactorily by P. Copinni of New York, the sculptor of the bust of Charles Broadway Rouss which adorns the Physical Laboratory.

All combustible material was eschewed. The floor, arches, and dome are of tiles made by the Gustavino patents. The northern elevation is a copy of the southern except that the portico is not so deep. The approach to this portico from the esplanade, which is coextensive with the area of the enclosing ramparts of the old Annex, gives the northern front a noble aspect.

Further additions to the external arrangement of the Rotunda are the four basement or terrace wings, joined together on the east and west by colonnades which are really continuations of those on the Lawn. The flat roof of these colonnades and terraces, together with the floors of the porches of the Rotunda, form a promenade around the entire chief structure of the University, guarded by a handsome balustrade.

Originally the Lawn was divided into four terraces descending from the Rotunda to the Triangle. A fifth was added in Mr. White's plan, and enclosed on three sides by new buildings, which, viewed from the portico of the Rotunda, seem but one story in 
height, although much higher. Only that elevation was allowed to appear above the terrace. The central one of these erections at the southern end of the Lawn, balancing the Rotunda at the opposite extremity, is the Academic Building, the largest and most significant of its immediate group. It contains numerous lecture-rooms and an imposing auditorium adorned with Breck's copy of the School of Athens. The facade delights those interested in architecture. Its portico is upheld by columns carrying Ionic capitals, while the tympanum bears a group modeled by Zolnay in illustration of the University's motto- "Ye shall know the truth and the truth shall make you free." This text appears in Greek among the details of the facade. Peristyles connect this structure with the Mechanical Laboratory, or Hall of Mechanic Arts, on the western side, and the Rouss Physical Laboratory on the eastern, and are covered with vines to afford a shade for belvederes, from which there is a fine view.

The destruction of M. Balze's copy of Raphael's School of Athens has been mentioned. An unknown friend of the University furnished the money to have another copy of the famous fresco made, and Mr. George W. Breck of New York executed it in Rome, having gained permission to make the replica directly from Raphael's work. It was formally presented to the University on April I2, 1902.

The estimate of nearly half a million for restoration and expansion did not call for more than was used. The resources were-

$\$ 200,000$ from proceeds of 5 per cent. bonds sold at par.

123,425 from the Fayerweather bequest.

35,000 from Charles B. Rouss.

56,973 from contributions of alumni and friends.

25,831 from insurance and interest.

$\$ 441,229$ 
The expenditures on the restoration of the Rotunda and the adjoining terraces, the erection of new buildings, the improvements to the grounds, etc., were divided, approximately, as follows :

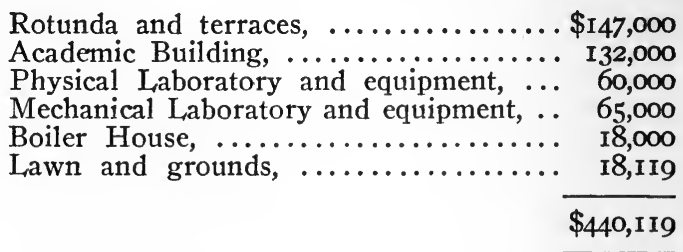

In all that has been done to repair the ravages of the fire and to expand the University good taste has controlled, with pleasing results. The Randall dormitory is an attractive structure viewed in its necessary relations to its site, and the hospital when finished as planned will be a worthy member of the general group. The last erection, Madison Hall, is beautiful, and apparently without fault under scrutiny from without and within.

Before passing from the consideration of University buildings something should be said as to the dwellers on the Lawn, the dwellings themselves having passed under review. The houses of professors have been designated from the beginning by numbers-the pavilions on East Lawn having the even ones and those on West Lawn the odd.

Considering West Lawn first: Pavilion I was first occupied by Professor Emmet. He moved to Morea, on the western limit of the University lands, in 1833 or 1834 , and it was seven or eight years before the next professor occupant arrived. During 
this interim the chaplains resided there, viz: Cobbs, Ryland, Tustin, Wilmer, Doggett, J. B. Taylor, W. S. White, and W. M. Jackson. In 1842 Professor Courtney succeeded the chaplains, and members of the faculty have succeeded each other from that day to this, the order being Professors Bledsoe, Gildersleeve, John R. Page, and Tuttle.

Pavilion III: Professors Lomax, John A. G. Davis, Magill, Griffith, Howard, Peters, James F. Harrison, W. C. Dabney, Garnett, Proctor Thomas H. Carter, and Professor R. C. Minor.

Pavilion V: Professors Long, Patterson, Gessner Harrison, F. H. Smith, and Kent.

Pavilion VI: Was not occupied by a professor until I 849 or 50, when Dr. John Staige Davis, Sr., became incumbent. Upon the death of Dr. Maupin, Dr. Davis moved across the Lawn to Pavilion VIII, and was succeeded in number VII by Professor Boeck, and he in time by Professor Noah K. Davis. In the beginning this pavilion was used for the $\mathrm{Li}$ brary until 1826, and in its lecture-room, now a drawing-room, many a culprit student has been "before the faculty," for many of the meetings of that body were held there. The Board of Visitors convened there for many years. One whose memory goes back much more than a half century recalls the preparations for the visitation, among them being "a large decanter with nine glasses and a place for loaf sugar." When the chaplains could no longer use Pavilion I they occupied VII. These were probably Chaplains Rosser, Robinson, White, W. G. Jackson, Manning and Wood.

Pavilion IX has had but four occupants-Professors George Tucker, McGuffey, Peters, and FitzHugh. 
On East Lawn: The first occupant of Pavilion II was Dr. Johnson, but the date of his entrance has not been preserved. His successors were Professors Warner, Cabell, W. C. Dabney, Buckmaster, and J. A. Harrison.

Pavilion IV: Professors Blaettermann, Kraitsir, Schele De Vere, and Kent. When Dr. Alderman accepted the presidency this pavilion was fitted up for the offices of administration, and Dr. Kent became joint occupant with Professor Smith of No. V.

Pavilion VI: Professors Key, Gessner Harrison, W. B. Rogers, J. L. Smith, Maupin, J. S. Davis, Sr., Venable, and Echols.

Pavilion VIII. Professors Bonnycastle, R. E. Rogers, J. L. Smith, Maupin, J. S. Davis, Sr., Venable, and Echols.

Pavilion X: Professors Dunglison, John A. G. Davis, H. St. George Tucker, J. B. Minor, and Lile.

Some of the pavilions were evidently vacant at times. Professor Key left the University in I827. The next occupant of his pavilion was Gessner Harrison, who was not a professor until 1828 . He moved across the Lawn in $\mathrm{I} 835$ to take Pavilion $\mathrm{V}$, when Professor Patterson went to Philadelphia to be director of the United States Mint. Professor John A. G. Davis also crossed the Lawn. He succeeded Professor Lomax in Pavilion VI in 1830, and when Dr. Dunglison left the University in 1833 and Pavilion $\mathrm{X}$ was vacant he moved into it. It proved to be his last home, for, seven years later, he was shot down nearly on its threshold. After moving from Pavilion X Dr. Dunglison occupied Pavilion VII temporarily.

Professor W. C. Dabney succeeded Dr. James F. Harrison in No. III in 1886, and Dr. James L. Ca- 
bell in No. II, across the Lawn, in I889, and died there five years later.

Hotel E, at the south end of West Range, was intended as the proctor's residence and office, but he preferred the Monroe house, and it was there that Mr. Jefferson went for the transaction of business. Whether it was ever moved between Mr. Brockenbrough's death, which occurred in I83I, and the time of Colonel Kemper's occupancy ( 1846-53) does not appear by anything written, and the memory of men is too infirm to rely upon. Certainly, in 1846 , the office was on Monroe Hill. In I853 it was in a room adjoining the hotel at the south end of East Range, now known as Levering Hall, and Colonel Prentis, the incumbent, dwelt in the hotel. The hotel was assigned to William Jefferies as a boardinghouse, and the proctor's office was returned to Monroe Hill. It migrated again to East Range when John E. Johnston became proctor in 1867. The proctor's residence was the present Alumni Hall, and his office was in a dormitory adjoining, and remained there until Col. Thomas $\mathrm{H}$. Carter, the last of the proctors, moved it to the quarters now occupied by the bursar.

The postoffice was migratory, too. An early location was in the present Jefferson Society Hall or a dormitory adjoining it; thence it was moved to the proctor's office when that office was kept on East Range by Colonel Prentis. Its next location was in Washington Hall. In $1855^{-6}$ the building at the entrance to the University grounds was erected and the postoffice transferred to it, where it has been since. 


\section{CHAPTER XXII}

\section{ATHLETICS AT THE UNIVERSITY}

JefFerson's ViEW OF THE PURPoses OF GyMnastics-Scope FIXED BY HIM UNEXCEEDED-FACULTY ENCOURAGEMENT -D'AlFoncE's SchOol OF EXERCISE-COMING OF BASEBALL AND FOOTBALL-BOATING-FIELD ATHLETICSTRACK RECORDS-FAYERWEATHER GYMNASIUM-INDOOR SPorts-Proposed ATHLETIC Club-house.

Two of the earliest papers in the documentary history of the University contain important statements on the subject of physical training. In the report of the Rockfish Commission Mr. Jefferson wrote in the summer of 1818 : "We have proposed no formal provision for the gymnastics of the school, although a proper subject for every institution of youth. These exercises with ancient nations constituted the principal part of the education of their youth. Their arms and mode of warfare rendered them severe in the extreme; ours, on the same correct principle, should be adapted to our arms and our warfare; and the manual exercise, military manoeuvres, and tactics generally, should be the frequent exercise of the students in the hours of their recreation. It is at the age of aptness, docility and emulation of the practices of manhood, that such things are soonest learned and longest remembered." And in the enactments for the government of the University, drafted before the institution was inaugurated, and printed in 1825 , he makes these provisions: "The two apartments adjacent to the basement story of the Rotunda shall be appropriated to the gymnastic exercises and games of the students; 
among which shall be reckoned military exercises. A military instructor shall be provided at the expense of the University, who shall instruct the students in the manual exercise, in the field evolutions, manoeuvres, and encampments. The students shall attend these exercises and shall be obedient to the military orders of their instructor. Substitutes in the form of arms shall be provided at the expense of the University. They shall be delivered out, received in and deposited under the care and responsibility of the instructor."

In neither of these deliverances appears any foresight of the games that were eventually to figure so largely in the athletic history of the University. For nearly fifty years the Jeffersonian view was but little exceeded. The first athletic utilities were quoits and marbles, and the arena was the covered spaces now occupied by the terrace-rooms which connect the Rotunda with the long colonnades. The University provided the quoits and marbles, which, when not in use, were in the custody of the janitor. No hint of professionalism, or charge of "summer playing" of quoits or marbles has come down from the heated contests of those early days; nor have any records been preserved.

A third official utterance on the subject of athlectics was made in 1852 . This time it was the Visitors who gave the weight of their approval to this form of culture: "The Board of Visitors being sensible of the importance of gymnastic exercises for the physical development of youth, have read with pleasure that J. E. D'Alfonce proposes to give instruction on that subject, and hereby renew the permission formally given for a site on the University grounds for a gymnasium, and are disposed to offer 
proper facilities, subject to such future regulation or discontinuance as they may deem expedient." Already the faculty had approved M. D'Alfonce, and the catalogue for the session of $185 \mathrm{I}-52$ announced that he would teach gymnastics under the authority of that body.

The gymnasium authorized by the Visitors was erected on the site of the present Academic Building and on the banks of the little stream near by was built a house for Russian baths. Both enterprises were directed by D'Alfonce, but fell into disuse during the civil war, when the buildings were destroyed. As a teacher the Frenchman is said to have been unusually successful, and no doubt by affording employment for the youthful energies of the students he contributed materially to the good order which prevailed from $185 \mathrm{I}$ to $186 \mathrm{I}$, the most prosperous decade in the antebellum history of the University.

In $\mathrm{I} 860$ some one introduced the game of cricket, and it was played in a field near the University cemetery. The University Magazine hailed its advent with pleasure, but literary enthusiasn for the Englishman's game could not maintain it, and it disappeared after a vogue of two years. It has reappeared occasionally.

After the war the students who came to the University from the battlefields of the Confederacy, some of them maimed and scarred in the conflict, either lacked interest in athletics or the time to indulge a prepossession for that field of endeavor. The small beginnings of baseball were noted derisively in the Magazine. These paragraphs which appeared in the number for June, I868, would be utterly impossible in any University publication at this day. 
"Baseball, a game which to our mind excites a very strange and unnecessary enthusiasm, has had quite a run since our last. The Junior Monticellos of the University were successful over the Excelsiors of Greenwood in two games, one on the grounds of each. The former, though young in the cause, conducted themselves in a becoming manner both in striving for success and after it was obtained.

"A match was also played between two 'muffing' nines in the University. The champions hailed from East Lawn and West Range. These muffers being rats in the cause, were seen on the day after the game to give signs of contracted muscles, swollen hands, flushed faces, etc.

"Our Monticello Club has lately been nipping in the field. On the $22 \mathrm{~d}$ inst. they met the Arlington Club of Washington College and easily defeated them by a score of fifty-four runs to nineteen runs. We advise the Arlingtons to practice another session and try the old Monticello again a year hence."

It was ten years later that a Washington and Lee team vanquished the 'Varsities on their own ground, through the uncanny, and hitherto unheard of, skill of the pitcher, Sykes, who delivered curved balls which no Virginia batsman could touch. The news went abroad in the University, and was laughed to scorn, except by the players who tried to bat the ball. It is said that the subject, incidentally introduced at a faculty meeting, excited a rattling debate, at times exhibiting touches of asperity, on the subject whether a baseball could be thrown with such control over its course through the air as would force it to describe a curve at a given point in its transit. The faculty minutes do not record the decision, but 
the question has since been answered on a thousand fields. The advent of the curved ball was about coincident with the disappearance of such local teams as "The Modocs," "The Bomb Stingers" and "The Pill-Garlicks"- at any rate, these names ceased to occur in the enthusiastic literature of athletics. Concentration of "talent" and effort resulted eventually in what has since been called The Team, and a subordinate organization of scrubs has as its sole raison d'etre the preparation of players to fill vacancies in the superior nine.

In the fall of 1870 the Magazine made its first reference to football-half-sarcastic, half-humorous gibes, which at this day would attaint the authors of philistinism. However, sarcasm quickly gave place to a tolerant humor.

It was in the year 1872 that the Magazine began to agitate for a gymnasium. At that time there were local gymnasiums on Carr's Hill, Dawson's Row, Monroe Hill, East Lawn and East Range, consisting of meagre equipments-bars, dumb-bells, Indian clubs, etc., in rooms of inadequate size, and there were horizontal and parallel bars at several points in the grounds, but in general it may be justly said that from the time of Monsieur D'Alfonce's departure in I 866 until I876 there was an athletic, or, as would have been said then, a gymnastic, interregnum.

The real athletic history of the University dates from I876. In that year Mr. E. R. Squibb of Brooklyn, New York, gave a thousand dollars toward the equipment of a gymnasium. The second floor in the present Levering Hall at the southern end of East Range was assigned by the University, and although too small was all that could be had until Daniel B. Fayerweather's bequest made a 
modern gynasium a possibility. The ladies of the community by favorite methods raised funds and contributed to the enlargement of facilities. and in one way and another the little gymnasium on East Range became an effective factor in physical life at the University.

In the session of $1876-77$ the brilliant but all too brief history of boating at the University had its beginning. Archibald G. Stuart of Staunton, Virginia; James C. Lamb of Richmond, Virginia; De Courcy W. Thom of Baltimore, Maryland; John M. Macfarland of Winchester, Virginia; and William J. L'Engle of Flọida, originated a movement looking to the establishment of a boating club. By some happy intuition they were lead to appeal to Mr. Francis Rives, of New York (M. A., '40), who promptly sent a check for $\$ \mathrm{I}, 000$. At a meeting held in Jefferson Hall on the I7th day of April, I877, the Rives Boat Club was organized with Archibald G. Stuart as president, George D. Fawsett, vice-president, J. C. Lamb, secretary, and W. J. L'Engle, treasurer. A boat-house was erected on the Rivanna at Farish's Cliff and the course lay between the Free Bridge and the dam at the Charlottesville Woolen Mills.

In an incredibly short time the club arranged a race with the Tobacco City Club of Lynchburg, which was rowed on James River, June 30, I877. The Rives boat was built of cedar, while the Tobacco City Club used a paper gig, an advantage which was added to by a foot more length and six inches less width. The University crew were William J. L'Engle, bow; Charles Steele, No. 2 ; J. M. Macfarland, No. 3; De Courcy W. Thom, stroke; Willoughby Walke, coxswain. They were admirably 
trained and victory was confidently expected, but in turning the stake the strain on seat No. 2 caused the rails to spread and dislodge the seat, leaving the rower to slide as best he might on the sharp steel runners. The bow oarsman, unable to slide forward to the stroke, because of the stationary condition of No. 2 , was also interfered with, and thus handicapped the Rives crossed the line one minute and two seconds behind their competitors.

The following year, 1878 , the Rives bore the red and gray-which were the University's colors before the adoption of orange and blue-to victory over the same course against the same competitor. The 'Varsity crew that year was T. N. Carter, bow; Frank Hampton, No. 2; B. D. Gibson, No. 3; Charles L. Andrews, captain and stroke, and John Redwood, coxswain.

The race which took place July I5, I879, was rowed at Fredericksburg against a local crew. It had scarcely the semblance of a race, for the Rives came in three hundred and fifty yards ahead of the Fredericksburgers. The crew consisted of the same men as in 1878 , except that $\mathrm{Mr}$. Hampton gave place to $\mathrm{Mr}$. Thom, who had been a member of the 1877 crew.

The Rives went into the race in 1880 with a new paper gig. It was not satisfactory in some particulars, but the defects were discovered too late to procure another boat. They rowed this year against Fredericksburg for a challenge cup given to the Virginia Association of Amateur Oarsmen by Major Seth B. French of New York, formerly of Fredericksburg. The crew was made up of veterans with one exception: Gibson, stroke; Hampton, captain and No. 3 ; G. C. Graddy, No. 2; Andrews, bow, 
and Redwood, coxswain. The race took place July 6 at Fredericksburg against the Appomattox and the Rappahannock clubs, and the Rives won by ten lengths.

The next race took place July 6 , 1881 , at Richmond. The entries were the Rives, the Appomattox, and the Cockade City of Petersburg, the Olympic of Richmond, and the Rappahannock of Fredericksburg. The Rives came in first, followed by the Olympic, the Cockade, the Appomattox, and the Rappahannock. The crew: Davies Cox, bow; P. C. Massie, No. 2; Graddy, No. 3; Andrews, stroke, and Redwood, coxswain.

The members of the crew for the race of July 4, I882, at Fredericksburg, were A. S. Doswell, bow; W. A. Harper, No. 2; S. B. Cowardin, No. 3; Massie, stroke; Redwood, coxswain. The entries were the Rives, the Olympic, and the Cockade City. The Rives won by eight lengths over the Cockade City and fifteen over the Olympic.

This was probably the last race in which the Rives took part. Thereafter the Magazine is silent on the subject of boating, except for a three or four line note in October, 1883 , announcing the election of Davies Cox as president of the club and certain other students for other offices. Out of six races five were won and accident alone prevented the winning of the sixth.

The Squibb Gymnasium Association was formed at about the time of the organization of the boating club, and a wonderful extension of athletic enterprises ensued. The Magazine - almost the only repository of the memoirs of student activities until the appearance of Topics-dates organized athletics at the University from April, 1877; and this judg- 
ment was announced as long ago as I88o. It was in I 877 that the first field day was held, a fact disclosed by a reference in an account of the games that took place in 1878 . Since that early day the following records have been made:

Ioo-yard dash-T. N. Carter, I878, I I $\frac{3}{8}$ seconds. Lowered by C.P. Kemper, I880, to I I ; G. H. Smith, I88 I, Iо $\frac{3}{4} ;$ L. Carroll, I882, Iо $\frac{1}{2} ;$ W. G. Bibb, I884, Io $\frac{1}{4}$; Allen Potts, I890, Io. These records wer not made on a regulation track. W. G. Brownlow in I894, on a regulation track, made the dash in IO I-5.

Putting the shot-W. D. Cardwell, I837, 44 feet 7 inches. The nearest approach to breaking this record was made in 1905 by $W$. W. Council, $3^{8}$ feet 6 inches.

Throwing the hammer-T. P. Crawford, I878, 64 feet 9 inches; broken by R. G. Rhett in I880, 65 feet and 4 inches; Ewing Cockrell, I895, I Io feet.

Half-mile run-De Courcy W. Thom, I878, 2 minutes $34 \frac{3}{8}$ seconds. Lowered by G. McD. Hampton, I879, 2 minutes $23 \frac{1}{8}$ seconds;; R. H. Laughlin, I894, 2 minutes 6 seconds, and P. M. McNagny, I905, 2 minutes and 5 4-5 seconds.

Running high jump-C. B. Walker, I878, 4 feet 5 inches; William Beazley, I879, 4 feet I I $\frac{1}{2}$ inches; I880, 5 feet I inch; Manly, I883, 5 feet $I \frac{1}{2}$ inches; H. Glenn, I895, 5 feet $8 \frac{1}{2}$ inches; A. C. Randolph, I906, 5 feet 9 inches.

220-yard dash-H. T. Harris, r88o, 25 seconds. Lowered by F. W. Harper, I893, to $22 \frac{3}{4}$ seconds; Hiram Smith, I905, 22 I-5 seconds.

Broad jump-C. B. Walker, I876, I6 feet 6 inches; C. P. Kemper, I879, I7 feet 4 inches; Lee Carroll, I882, I9 feet 3 inches; Michael Hoke, I895, 
20 feet 6 inches; J. S. Adkisson, 1904, 21 feet 6 inches.

I20-yard hurdles-Martin Bruns, I893, I6 I-5 seconds; broken by A. C. Randolph, I905, I 5 4-5 seconds.

440-yard dash-T. N. Carter, 1878, 585 seconds; Frank Hampton, I879, 57 $\frac{3}{4}$ seconds; Carroll, I88I, 54 seconds; C. J. Kinsolving, I894, 523 seconds; J. H. Shelton, 1905, 5 I I-5 seconds.

I-mile run-C. L. Andrews, I878, 5 minutes $32 \frac{5}{8}$ seconds; Hampton, 1879,5 minutes $3 \mathrm{I} \frac{1}{2}$ seconds; Davies Cox, I88I, 5 minutes I2 $\frac{1}{4}$ seconds; J. W. Graves, I882, 5 minutes $2 \frac{1}{2}$ seconds; 1884,4 minutes $56 \frac{3}{8}$ seconds; A. W. Butts, I905, 4 minntes 5I 2-5 seconds.

I-mile walk-A. B. Pope, I878, 8 minutes $55 \frac{1}{2}$ seconds; Cator Wade, I88I, 8 minutes I I $\frac{1}{2}$ seconds; R. T. Irving, 1888,7 minutes and 24 seconds. This record was tied by $\mathrm{H}$. S. Hedges in 1892 .

Pole vault-Rhett, I880, 8 feet 7 inches; F. W. Harper, I893, 9 feet 6 inches; E. L. Taylor, 1905, Io feet 7 inches.

If the organization of the Squibb Gymnasium of I 877 introduced a new spirit in athletics, the enlargement of gymnastic facilities added to the impetus, organized its forces, and improved its methods. The Fayerweather Gymnasium, with an equipment then beyond the needs of the institution, was built and furnished in 1892-93. The records of field sports made during the previous fifteen years were in most events speediy broken. Football and baseball records have been kept since 1889 . In that time Virginia has played ten games of baseball with Cornell, winning 5 ; 8 with Johns Hopl ins, winning 6 ; 
22 with Lafayette, winning I5; I9 with Lehigh, winning II; I7 with Pennsylvania, winning 5 ; I8 with Princeton, winning 4; 26 with Yale, I tie and winning 6.

In football, in the same time, Virginia has played four games with Johns Hopkins, winning all; 4 with the Carlisle Indians, I tie, and winning I; 3 with Lafayette, I each, and a tie; 3 with Lehigh, winning I ; I4 with North Carolina, a tie, and winning 9; Io with Pennsylvania and 3 with Princeton lost.

In I894 indoor sports showed the result of the directing and reforming skill of Dr. W. A. Lambeth, the instructor in physical culture. The Fayerweather Gymnastic Association was put in charge and has done much to popularize winter sports and games. Their quarters in the gymnasium are now far from ample.

Away back in the late eighties an athletic association was formed as the result of the influence, sound judgment and active interest of the late R. D. Anderson, and some others, among whom was Felix H. Levy of Galveston, Texas. This organization became the General Athletic Association and was incorporated in I894. In the election of its officers, made by ballot, every alumnus and student has a vote. Under its direction the athletic affairs of the institution have been so well managed that it has accumulated a considerable property. The greatest achievement, perhaps, has been the making of Lambeth's Athletic Field, one of the best arenas for college sports in the United States. The contract for grading the field was let in January, I900, and the first games occurred there in 1902.

Before Lambeth's Field was available baseball and football were played on indifferent grounds on the 
south side of the University. About 1894 the running track on those of the present Madison Hallnow largely taken up as tennis courts-came into use, and, indeed, is still resorted to.

The General Athletic Association and the General Alumni Association are jointly committed to the erection of a large house for common use as an athletic and alumni club-house, a need of long existence, especially for the entertainment of alumni and guests on special occasions of reunion. There is also pressing need for some forms of athletic facilities which the club-house will meet, such as training table conveniences, a home for the Association's organ-College Topics-a museum for trophies, etc.

The architect's plans are in hand. They provide for a building of four stories-a basement with servants' quarters, etc.; first floor with a central reception hall, a statuary hall, dining room, trophy room, editorial room, bed-rooms, etc.; third floor, bed-rooms and bath-rooms. From the rear of the main hall, which is two stories, there is to be a semicircular balcony overlooking the athletic field. The estimated cost is $\$ 72,000$, of which $\$ 15,000$ is in hand and $\$ 12,000$ pledged.

It may be that here and in other similar institutions the golden age of athletics has been reached and an era of decline is at hand; that some other employment of the surplus energies of college men must be found. If so, may the new worship of the collegian be as fit as the old, and develop a manhood as clean and strong. 


\section{CHAPTER XXIII}

\section{OTHER STUDENT ACTIVITIES}

Social and Club Side of Life-Gréte LetTter FraternnitiesClubs and Organizations- "Hot Fetep"-Ord Time DYKE-DECLINE OF "FINAL" FESTIVITIES-EASTER WEEK THE MERRY 'TIME.

Student life is many sided. The literary societies, intercollegiate debates, the Y. M. C. A., and athletics by no means include all the enterprises which claim a share of their fresh vigor and enthusiasm. They strut the stage as members of the Dramatic Club, they woo applause as singers of glees or players of stringed or other instruments, appear as goats of wondrous hue and circumstance and later as affiliates in Greek letter fraternities and ribbon societies. They pay the fiddler in german clubs, the confectioner and the liveryman after "Home, Sweet Home," and by the time four years have run their eventful course they have seen and felt much, and the world finds them ready for the battle of life, in which history bears witness they quit themselves like men.

Corks and Curls, published by the Greek letter fraternities, mentions the following Chapters as located here: Eta Chapter of Phi Kappa Sigma, Eta Chapter of Delta Kappa Epsilon, Virginia Alpha Chapter of Phi Kappa Psi, Omicron Chapter of Beta Theta Pi, Alpha Chapter of Chi Phi, Virginia Omicron Chapter of Sigma Alpha Epsilon, Omicron Chapter of Phi Gamma Delta, Upsilon Chapter of Delta Psi, Zeta Chapter of Kappa Sigma, Psi Chap- 
ter of Sigma Chi, Virginia Delta Chapter of Alpha Tau Omega, Alpha Chapter of Pi Kappa Alpha, Beta Chapter of Zeta Psi, Virginia Beta of Phi Delta Theta, Lamda Chapter of Kappa Alpha, Beta Iota Chapter of Delta Tau Delta, Minor Chapter of the Legal Fraternity of Phi Delta Phi, Alpha Chapter of Lambda $\mathrm{Pi}, \mathrm{Pi} \mathrm{Mu}$ Chapter of $\mathrm{Nu}$ Sigma $\mathrm{Nu}$, Sigma Chapter of Phi Rho Sigma, and Pi Phi Chapter of Theta $\mathrm{Nu}$ Epsilon.

Among the clubs and organizations-so-called in contradistinction to fraternities-are the State and school clubs, the Arcadians, the Graduate Club, the Raven and Beetle, and a half score other societies. Among these the Eli Banana was founded in 1878 , and is the oldest of the Ribbon Societies. T. I. L. $\mathrm{K}$. A. has a shorter history, but it is of the same general character. Both are purely social. The Thirteen Club takes its members from the rolls of Eli and Tilka, and has for its motto: Superstitio solum in animo inscii habitat. The $Z$ Society is the most secret ribbon organization. Its membership, like that of the Thirteen Club, comes from Eli and Tilka. Its notices or signs are written in the night-time on buildings or sidewalks. The members of the Seven Club are unknown. They are likewise nocturnal sign writers. The O. W. L. gets its members from the ranks of editors-in-chief of student publications.

There are other organizations, such as the Glee and Mandolin and the Graduate clubs, whose reason for existence is declared by their names, and one whose name- "The Hot Feet"-does not yield more than a puzzling modicum of information.

In the spring of 1902 several residents of East Range, stirred by the spirit of unrest, organized a baseball team for the dual purpose of exercise and 
contests with teams from other localities in college. This team's reputation was supported by the good fellowship and congeniality among its members rather than by its success at baseball, and this fact influenced the choice of a name. The third baseman recalled a team from North Carolina with equal congeniality-and probably more skill-which starred under the name of the "Hot Feet," and this application the East Rangers took to themselves. When baseball days and examinations were over, the alumni, retuurning to participate in the celebrations of Finals, took home very strange and picturesque stories of these "Hot Feet" with their hospitality and ringing song.

The following fall more "feet were warmed" and the organization-loosely imperfect-was completed and preparations made for the coronation of a king. True to all predictions, in the spring Ernest I was crowned King of the Hot Feet in a ceremony which immediately attracted the attention of college, unused and opposed to new organizations. From this time onward, the "Coronation" was regarded as one of the occurrences of the session, and the next spring it was awaited with great interest and expectancy. The "Hot Feet" did not disappoint the University, and before an audience composed of three hundred students and several professors the second king of the "Hot Feet" was vested with sovereignty. This was King Vski I and his "inaugural address" will long be remembered as one of the wittiest and happiest speeches ever heard in the University. His choice of one of the Dramatic Club cast "girls" as queen met with general approbation and, along with the Wizard and Court Jester, "she" delighted the royal subjects and audience by her gracious manner. 
The Heir Apparent, a football boy of some two hundred and forty pounds, was also a favorite, and with his short socks and chubby legs he was the object of much attention.

The triumphal procession around the college was then made. The King, seated upon his automobile chariot with beer-keg wheels, bore his honors with gentle courtesy and was very solicitous as to the welfare of the Heir, who followed him upon a single rolling keg, directed by the Jester. The ermine mantle of his majesty and the armor of the Generalissimo-attired as a knight of the fifteenth century-were in contrast to the wig and red robe of the Lord High Chancellor, while the petty officers with their insignia, followed by the loyal subjects, each in his dressing gown with a red foot on his back and a "Happy Hooligan" tincup on the side of his head-made a picturesque group, which has been well preserved by the photograph of the Coronation.

Although it would seem that the organization has no serious purpose other than to make fun for college and themselves, some of the most brilliant men in the University have been numbered in its ranks. Ever since its foundation, the "Hot Feet" have had as members the editors of all three college publications, some members of the Advisory Board of the Athletic Association, the presidents of the classes, and have made more degrees than any other organization of anything like the same size.

The members for the first year or so were exclusively from East Range, but at present the place of residence has been made subordinate to the congeniality of the man and his willingness to serve the 
organization, so the college impartially contributes its quota.

The song of the society-known as the "Hot Feet Song"- - has carried its fame and reputation far and wide. It is the composition of one of the founders, set to parts of a well-known light opera, and is the best marching-tune in college.

While partaking somewhat of the nature of the "Hasty Pudding" Club at Harvard, the "Hot Feet" of Old Virginia are a more original and unique organization, embodying the spirit of fun and merriment so familiar to colleges and college men.

The success of the "Hot Feet" is due in large measure to that love of extravagance, burlesque, and horse-play which fills many cities of the world every year with merry-makers throwing confetti and doing a thousand absurd things in obedience to an amiable and frolicsome mood. Before the "Hot Feet" and their grotesque but harmless pranks came the calathump, a reckless uprising of students with no aim but to make a noise as rowdy and foolish as the civil authorities' would tolerate, and the better natured "dyke," an escort of honor thrust upon a braw wooer on his way to the worshipful presence of the lady of his dreams. This description, true to the life, will bring back to the memory of many a victim the terrible cry of "dyke," if indeed a victim ever forgot it:

"That ominous quiet which in the books always lets you know of the approach of a fine large catastrophe, had been brooding over College all that October afternoon, and about nightfall it hatched out that most startling phenomenon, a dyke. To the uninitiated, the first intimation that that thing had arrived was the mournful sound of a young fishhorn 
over on Monroe Hill. It was immediately echoed from East Range, and then from the Lawn the single word 'Dyke!' cut into the air and made the clock feel doubtful about the time.

"In five minutes College was alive with the Dykers. Old clothes were torn up, tied on sticks and broom handles, saturated with oil and elevated to the honorable position of torches. Coal scuttles with the assistance of tongs and pokers, sprang at once into prominence as substitutes for shawms and sack-buts; while loving hands bore aloft in reverent pride the monarch of horns-the Big Horn of the Range. This celebrity lived in 2I West Range, and was regarded by the dwellers in that precinct with an affection hard to understand to those who have never heard its voice. The animal-for I have never gotten over the feeling that it was alive-was, when at rest, some four feet long, but by a telescopic arrangement could be lengthened much beyond that for use. No mortal lungs could ever blow enough air into it to produce even a grunt from its sinister jaws, but he who knew how to draw it out and telescope it quickly had the proud pleasure of producing a sound which would have made a phonograph despair. Its note was a very rough, hoarse bark, and had no redeeming features.

"When I arrived at the Lawn on the evening in question a wonderful scene met my eyes. The light from some hundred torches made the arcades as bright as day, and advancing up the Triangle at a comfortable run came nearly half of College. A pale man in a dress suit, with his cravat on the back of his neck, and a frightened, hunted look in his eyes, led the band. He walked entirely on his heels, and remarked now and then to those in his imme- 
diate vicinity, who were assisting him along, 'Don't be so funny!'

"A small and very fierce red-headed man and an obese boy with sad eyes held torches for him at the correct angle to allow the oil to strike the brim of his hat and run merrily down his neck, and the big horn rested lovingly on his stiff collar and from time to time poured its tale of love into the fearful hollow of his ear.

"Up to the old Rotunda steps the host came on, and in an incredibly short space of time the victim was standing on the porch, while the crowd yelled 'Speech!' If the man had ever seen a dyke before, he would have remained silent, but he seemed to think that the whole business was just a novel way of getting him to talk; so he pulled himself together and nervously reached around for his cravat, but his hand encountering the awful muzzle of the big horn, he gave up the search, and in a conciliatory Casabianca tone began: 'Fellow Stu-'

"There are no records to show that any man ever got farther than this. His opening words turned the tumult loose again. The horns went wild, the torches waved and rustled, and the crowd cried, 'Speech! speech!' when there was no speech, and making a rush for the orator bore him back down the Lawn at a most enthusiastic pace.

"Quick as thought a double line formed in front of the house in which the entertainment was in progress, and through whose hospitably open doors could be seen the bright lights and expectant faces among which he was so soon to make his unwilling appearance. As the unhappy man went down the line on the arms of his two conductors, the crowd closed in behind him until the door was reached, 
when their united impetus bore him with a tremendous rush right into the hall, and left him to the sympathy of the ladies. Several sly gentlemen took this opportunity to slip in with him, and thus escape; but one, who could not forbear pausing on the threshold to express his exultation, had the humiliation to be caught by the crowd and receive as neat a dyking as the most fastidious could desire.

"It was about this time that the fierce little redheaded man, whom I had the misfortune of sitting by in the Latin class, spied on the outskirts of the crowd my reticent figure, and shouted 'Here he is!' It was said afterwards that the big horn barked twice. I only heard it once. The crowd yelled 'Dyke! dyke!' All the joke of the thing had evaporated for me, and, like the old Homeric heroes when the long-shadowed spears became too numerous for them, I remained in that place, not any longer at all."

Once upon a time the gayest period in the session was commencement week. The final ball was a great social event in Virginia, and girls flocked to it from far and near. All night the arcades heard the flute and violin in the Rotunda, the dancers dancing in tune, and all that goes with a night of youthful revelry, but the glory of the final ball has been sadly diminished. The Easter dances by the German Club, Tilka, Eli, and other organizations; the ball games on Lambeth Field, the gay gatherings there, full of life, movement and color-everything that is Easter week at the University has made that the merriest time of all the year. A tolerant good nature goes with the season, the lectures proceed,

${ }^{1}$ The late Thomas Longstreet Wood, in Corks and Curls. 
and the students, who were up late the night before, go to sleep discreetly right under the professorial nose; on the ball field battery and basemen make errors galore, but lecturer, and grand stand, and bleachers pardon all corks and muffs and wild throws, not for the sake of the Easter girl, but because she is abroad in the land. 


\section{CHAPTER XXIV}

\section{RELIGIOUS ACTIVITIES}

No Compulsion in Reilgious Observances-Professors and OFFICERS ARRANGEd FOR SERVICES AT THE UNIVERSITYINSTITUTION OF THE CHAPLAINCY-GENERAL, SECRETARYSHIP OF THE Y. M. C. A.-RELIGIOUS WORK FOR THE Students and by. Them-Madison Hali.

Eighty years ago there was probably not an institution of higher education in America that did not owe allegiance to some religious denomination. It was therefore a startling innovation that the Rockfish Commission proposed-a State university without religious affiliation. No provision was made for religious or theological instruction, and yet no member of the legislature felt called upon to propose either condemnation or approval. There was a new spirit abroad and Jefferson's policy embodied it; and so when the doors of the school were opened and students filled the lecture-rooms, a new era had dawned in which there was not to be compulsory attendance upon religious services, and in which the students, free to select their own studies, were equally free to choose their religious privileges.

$\mathrm{Mr}$. Jefferson was not dependant upon the clergy, but the dwellers in his academic village desired their ministrations. The court-house in the village of Charlottesville served in some measure as a church for the little community in which there was not a single house of worship, but it was too far away, especially in winter, because the intervening way was covered with thickets through which ran a very bad road. The Rev. Frederick W. Hatch, an Episco- 
palian clergyman, and the Rev. Francis Bowman, a Presbyterian minister, by an arrangement with the professors in their private capacity, preached alternately in one of the lecture-rooms in the Rotunda. The year in which this plan was inaugurated cannot be determined, but it ended in 1829 , when the chaplaincy was instituted, and a Mr. Smith, a clergyman from Philadelphia, became the first incumbent. These clergymen were paid by the voluntary contributions of the professors and students, as all religious services of the University have been compensated.

The chaplain system of religious administration persevered for nearly seventy years. In 1854-55 a parsonage was erected on the grounds of the University by the consert of the Board of Visitors. This accomplished, steps were taken for the building of a chapel. The story of it is serial and long drawn out, as far as years go, but a highly creditable one for the makers of this part of the history of our University. More than once the faculty earnestly discussed the location of the chapel long before the means for its building were at hand. At one time a site near the present Mechanical Laboratory was considered, but later (I86I) the whole matter was held in abeyance to await the issue of plans then under consideration for the erection of wings to the Annex in one of which it was proposed to locate a chapel. One of the mercies of the war was the enforced abandonment of this further extension of an architectural monstrosity. It was not until the chaplainship of the Rev. Otis A. Glazebrook (I883-85) that the present structure, an impressive Gothic edifice, was completed after years of devoted effort, in which, as usual, the ladies of the University 


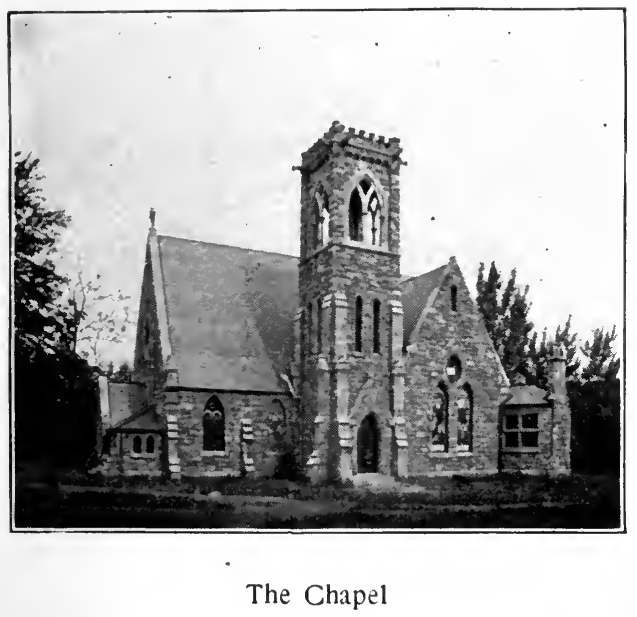

OPPOSITE P. 316 

lent a hand. In the meantime the eastern basement wing of the Rotunda served all the purposes of a chapel on ordinary occasions. It was first used in I84I or 1842 .

The chaplains to the University were almost without exception men of ability, and many of them became eminent in various fields. The roll is made up, because the system is no longer in vogue, and is interesting in several particulars. ${ }^{1}$

Dr. A. R. Cocke was the last chaplain who served, although the last appointed was the Rev. L. C. Vass, whose term would have embraced the session of I 896-7, but he died September 28, I896, and the following month a decision was reached to devolve upon a general secretary of the Y. M. C. A. the pastoral and administrative duties, and to have the chapel pulpit filled by preachers selected by a committee. Already a secretary had been giving a part of his time to college work. Two students, at least, had been so employed - the late J. I. Curtis, during the session I893-94, followed by I. C. Harrison, who remained in the field until March, I896. Under the new system, however, W. I. McNair was the first incumbent, entering upon the duties November I5, 1896 , and continuing until March, 1898 , when he was succeeded by J. M. Broadnax, whose services ended June, I900. Herbert J. Gallaudet was the next secretary, but, his health failing, he retired, and W. M. M. Thomas completed his unexpired term. For I90I-2 Robert Beale, Jr., performed the onerous duties of the office, and the next session saw the beginning of the administration of Dr. Hugh M. McIlhany.

\footnotetext{
${ }^{1}$ For the chaplains and the presidents of the Y. M. C. A., see pages $370,37 \mathrm{I}$.
} 
It was long believed that the University Y. M. C. A. was the first college association in the world, that its formal organization took place in the fall of I857, and that it had been planned and decided upon in the previous spring; but the recent discovery of its first printed circular has established the truth of its history in this respect. This circular was signed by J. William Jones, Randolph H. McKim, and John L. Johnson, and states that the association was formed November I2, I858. Dr. Charles A. Briggs, using the methods of the higher criticism, had proved to his satisfaction that the day of its foundation was either the first or twelfth of November, I858. The beginning was not weak. "As in Geneva in 1858 ," so runs one of the reports of that day, "the roll was called by nations, and then there arose one after another representatives from England, America, France, Germany, so here [in the University Association] it might be called by States and the voice of our Union from New York to Texas, and from North Carolina to Missouri wonld be heard."

Religious activity among the students at that time is shown by a statement taken from a report: "Every Sabbath some fifty young men are actively engaged in preaching the gospel either in the Sunday-schools of Charlottesville or the University, or, willing to forego the privilege of the sanctuary during the day, as missionaries to different parts of the surrounding country."

The missionary spirit has not abated. The University has more than forty of its alumni in the foreign field, and others are preparing for the work. More than three per cent. of the matriculates of the institution have gone into the ministry, and at this 
time twenty-five young men are pursuing studies in preparation for it. The work of the Association among students and for them includes a mid-week prayer-meeting, about twenty Bible classes which enroll a fourth of the student body, four mission classes with an enrollment of eighteen, a board of systematic giving to missions, a voluntary band of ten pledged to the foreign field, voluntary neighborhood mission work in which thirty men are engaged, and a ministerial band of twenty-five. The Association issues a hand-book, which is very helpful to new men, publishes a weekly paper dealing with association interests, an annual report, and a directory; maintains summer correspondence for the information of prospective students, an information bureau, a boarding-house register, and at the opening of each session gives a reception with the purpose of bringing the young men into pleasant personal relations with each other. To all these good works must be added the advantages of an excellent library-the gift of Miss Grace Dodge of New York-and the opportunities for tennis in the eighteen courts on the Y. M. C. A. campus. More men engage in this form of athletic amusement than in all others combined.

From this brief catalogue the conclusion may be safely reached that the general secretary leads a very busy life, planning and executing. Fortunately he has able and devoted young men as his assistants. The members of the various boards and committees are carefully chosen for service, and the service is rendered with fidelity. The presidents of the As- 
sociation $^{2}$-of which there are two each year-are selected for results and the results follow.

Madison Hall, the home of this busy Association, is within a stone's throw of the Rotunda, and faces the north front of that building. It is the gift of Mrs. William E. Dodge and her family, of New York, and named in honor of James Madison, who succeeded Jefferson in the office of rector of the University. Mr. Madison was an alumnus of Princeton, the alma mater of Mr. Dodge. The cost of the building and furnishings was $\$ 80,000$, and it has an endowment of $\$ 20,000$, subscribed by students, alumni and friends. The architecture in its main features is colonial.

The ground floor is devoted to three editorial rooms, for the Magazine, College Topics, and Corks and Curls, and rooms for games, smoking, exercise, tea, baths, etc. The main floor contains a large reception and lounging hall, reading room, meeting room to seat one hundred, lady's parlor, secretary's office, writing room and auditorium, seating four hundred and fifty. The second floor, two rooms for Bible and missionary meetings, guests' rooms, etc. The frontage is 150 feet and the depth is 125 feet in the center.

\footnotetext{
${ }^{2}$ For a list of the presidents from the beginning, see page
} 372. 


\section{CHAPTER XXV}

\section{THE ALUMNI ASSOCIATION}

Founded in I838-First OfFICERS AND Orators-Chartered iN I873, AND AgAiN IN I903-ITS PURPOSES ANv GROWTH.

On the fourth of July, 1838 , the following gentlemen asembled in the Library: Robert C. Stanard, George N. Johnson, William B. Archer, John H. Christian, Alexander Moseley, Jacob D. Dudley, Thomas H. Ellis of Richmond, William Frazier of Staunton, Robert J. Davis of Lynchburg, Franklin Minor, Thomas Wood, Alexander Duke, Pike Powers, George W. Trueheart of Charlottesville, Willis P. Bocock of Buckingham, Beverly Jones of Mecklenburg, Charles B. Hayden of Smithfield, Samuel J. Douglas of Southampton, Francis S. Sampson of Goochland, Thomas T. Bouldin of Charlotte, Charles D. Morris of Caroline, J. Bolling Garrett of Albemarle, Thomas S. McClelland of Nelson. Several members of the Board of Visitors-Joseph C. Cabell, John H. Cocke, Chapman Johnson, and Th. Jefferson Randolph; and all the members of the faculty-Bonnycastle, Blaettermann, Emmet, Tucker, Davis, Rogers, Harrison, Griffith, and Cabellwere present by invitation. The business in hand was the organization of a society of the alumni.

The movement for this association grew out of a request of the Board of Visitors, made in 1837 , that the faculty invite a graduate of the University to deliver an oration on the 4 th of July, I838. The request was complied with, and then, on February 6 , 
I838, a committee was instructed to invite the alumni to form a permanent society to meet at the termination of each session. The committee, consisting of those wise men, Tucker, Davis and Emmet, urged that a society of this kind, which would offer to the graduates of the University an inducement to revisit the scenes of their youthful studies and give new life to the disinterested friendships formed in student days, would be attended with the happiest results, and prove propitious to the interests of the University. All of these expectations have been met in good measure by the society organized at the meeting in the Rotunda on the $4^{\text {th }}$ of July, I838. A constitution was adopted forthwith and the following elected the first officers: Alexander Moseley, president; Willis P. Bocock, George N. Johnson, vice-presidents; Thomas H. Ellis, secretary, and George W. Trueheart, treasurer.

After his return to Richmond, Mr. Ellis, the secretary, had a suitable book of the best material made in which to record his carefully prepared report of the organization. It continued to be used until Sheridan's raid through Virginia in I864. Major Green Peyton was secretary when the war came on, and left this minute-book in his private office in the building in Charlottesville in which he had been conducting a weekly newspaper. Sheridan's men pillaged the office and the book was never seen afterwards. Fortunately, Colonel Ellis had printed his account of the society and a copy of the pamphlet is preserved at the University. The proceedings of the society are now stenographically reported and printed in full.

Chapman Johnson was the choice of the society for orator at the commencement of 1839 , but the 
state of his health forced him to decline, and R. M. T. Hunter delivered the address. James C. Bruce of Halifax was the orator for I840. In this year a banquet concluded the festivities. The Collegian makes a note of it: "The alumni closed their sitting on the evening of the fourth with a dinner provided at the Monticello House in Charlottesville [the ancient Stone Tavern, where Jefferson sat in session with the other trustees of the Albemarle Academy]. It was partaken of in the true spirit of friends met to revive every hallowed feeling connected with their alma mater and to record the proud deeds of life. The greatest social glee prevailed and all were sorry when time proclaimed the arrival of the hour for their separation. The renewal of friendship's sacred pledge formed the last and most interesting scene of the meeting."

At this meeting Charles L. Mosby was chosen orator for I84I, and Alexander Rives named as alternate, but neither served. Mr. Bankhead of Fredericksburg discoursed on that occasion. It is to be regretted that the history of the society cannot be traced by definite steps. We learn that William M. Burwell was the orator in 1847 . It is a far cry from that year to 1858 , the next year in which an address is known to have been delivered-this one by Charles S. Venable, the great mathematician. James C. Southall, distinguished for his investigation into "the recent origin of man," was the orator in 1860. Here again war interposes its ugly presence to the suspension of more desirable activities. From 1867 the list of orators is complete. ${ }^{1}$

The society was chartered in 1873 . From the beginning the basis of the organization had been in-

${ }^{1}$ This list, with other information, is given on page 373 . 
dividual membership, which precluded anything like united action, because only a small percentage of the members ever attended a meeting, and each member represented himself alone. An experience of a quarter of a century under the first charter convinced the alumni that a different organization was imperative and the present arrangement was gradually evolved. It provides for local associations under constitutions and by-laws of their own adoption, each to become a chapter of the General Alumni Association under conditions not hard to comply with. The meetings of the General Association were constituted of delegates from the chapters, and each delegate's vote had numerical strength proportioned to the membership of the chapter he represented. A new charter was granted in 1903 , based upon this plan, and since that time the growth of the organization has been very vigorous. A day has been set apart in the commencement program and known as Alumni Day, on which the annual meeting is held, and the annual oration is delivered. The oration has been an event from the beginning, and great orators, statesmen, and scholars have gladly accepted the invitation to deliver it. 


\section{CHIAPTER XXVI}

\section{THE SCHOOLS FROM I825 TO 1905}

PRINCIPLE OF INDEPENDENT SChOOL,S-PROFESSORS INDIVIDUALLY RESPONSIBLE-EXAMINATIONS AND HONORSTITLED AND UNTITLED DEGREES-Changes IN THE SCHOOLS-SUCCESSION OF PROFESSORS.

In Mr. Jefferson's plan each school was to have its own building, and to be in charge of a professor responsible for his methods and achievements to the rector and Board of Visitors, but not to his colleagues. This collection of independent schools combined constituted the University of Virginia; and the independent professors its faculty.

The principle of accountability was immediately effective. The professor had every incentive to do his best to elevate and advance the school assigned to his care. Each was paid a fixed salary of \$1,000 a year, and a certain proportion of the tuition fees received from the students in his classes. This added an inducement. The more successful the school the larger the professor's emolument.

Another innovation in higher education was the permission to the student to choose the subjects which he would pursue while studying in the institution, two conditions only being imposed-that he be suitably prepared for the chosen classes; and that he take three of these, in order that his time be fully employed. This system of election clearly indicated Mr. Jefferson's purpose to found a university, for he would scarcely have approved the application of this method to the usual college work. Indeed, he had no conception of the modern college. 
In the enactments of I825 Mr. Jefferson's plan for examinations, and consequent honors, is outlined at length :

"The examination of the candidates for honorary distinction shall be held in the presence of the professors and students in the week preceding the commencement of the vacation. At these examinations, shall be given to the highly meritorious only, and by the vote of the majority of the professors, diplomas, or premiums of medals or books, to be provided by the University, to wit: diplomas to those of the highest qualifications; medals, of more or less value, to those of a second grade of acquisition; and books, of more or less value, to those of a third.

"These diplomas shall be of two degrees: the highest of Doctor, the second of Graduate; and the diplomas of each shall express the particular school or schools in which the candidate shall have been declared eminent, and shall be subscribed by the particular professors approving it.

"But no diploma shall be given to any one who has not passed such an examination in the Latin language as shall have proved him able to read the highest classics in the language with ease, thorough understanding and just quantity. And if he be a proficient in Greek, let that, too, be stated in the diploma; the intention being that the reputation of the University shall not be committed but to those who, to an eminence in some one or more of the sciences taught in it, add proficiency in those languages which constitute the basis of a good education, and are indispensable to fill up the character of a 'well educated man." "'

The second paragraph of this plan emphasizes once more the responsibility of each professor for 
the work of his school. The diploma is a school diploma, and is made to impart such significance as the character and worth of the professor can confer.

In 1826 the faculty reported to the Visitors a plan for the public examinations. They recommended that a committee of the faculty for each school, and not the faculty as a whole, should hold the examinations; and that the examinations be written instead of oral. A further recommendation was-

"To drop all the old unmeaning titles, and adopt in their stead the single term of 'Graduate,' except in the Medical School, where it will be necessary to retain the title of M. D. The degree of Graduate shall be conferred on those only who have acquired an accurate and extensive knowledge of the subject of one or more of the classes (in a school), or in any single language. But it is understood that in every case the candidate shall give the faculty satisfactory proof of his ability to write the English language correctly. The certificate of each graduate shall express each particular subject in which he shall have been declared eminent, attested by the particular professor. But these degrees shall be conferred only by a vote of the majority, and in the name of the whole faculty. The exact title shall be Graduate U. V."

While the Board consented to these changes, it took up again the question of examinations and degrees, and at the meeting in 1828 the faculty was asked -

"To consider and report to the Board whether some change be not proper in the regulations concerning degrees; whether it may not be proper to adopt the ancient denominations of Bachelor, Master, and Doctor, or some of them; and whether it be not proper to prescribe, as nearly as may be, what 
kind of proficiency in the learning of the several schools shall entitle a student to each degree, always holding in view the necessity of making a degree an evidence of real merit, and a reward for the requirements of persevering industry."

The result of the faculty's deliberation was its report in favor of a degree entitled Master of Arts of the University of Virginia, which, as finally arranged (1832), required graduation in the schools of Ancient Languages, Mathematics, Natural Philosophy, Chemistry, Moral Philosophy, and in at least two of the languages in the School of Modern Languages. For more than fifty years, during which some changes were made in the requirements, this degree was the highest academical honor conferred by the University. At present the candidate for the M. A. must in general be in possession of a preliminary baccalaureate degree, although the B. A. U. Va. and the M. A. are occasionally conferred simultaneously. The candidates for the higher honor must satisfactorily complete four M. A. courses in the University.

(I) Bachelor of Arts of the University of Virginia (B. A. Univ. Va.); established I848, when the requirements were graduation in any two of the scientific schools (Mathematics, Natural Philosophy or Chemistry), and in two of the literary schools (Ancient Languages, Modern Languages or Moral Philosophy), and also distinction at an intermediate and final examination of the junior class of the two remaining academic schools.

(2) Bachelor of Science, I868, discontinued I880, and re-established I882 as Bachelor of Science of the University of Virginia (B. S. Univ. Va.); requirements, graduation in Pure Mathematics, 
Natural Philosophy, General Chemistry, and Natural History and Geology. The degree of Bachelor of Science went into a kind of partial eclipse in I889, but it is thrice referred to in the catalogue of the Department of Engineering as existing - that is to say, in 1896,1897 and 1898 . In the announcement for the session of $1897-98$ it is said that "the B. S. is conferred upon a student who has been graduated in seven B. S. courses selected from the following five groups, but so that at least one course is taken from each group, and has in addition been graduated in two of the seven schools elected." The groups referred to were: I. Mathematics and Mechanics; 2. Physics and Astronomy; 3. Chemistry and Analytical Chemistry; 4. Geology and Biology; 5 . Applied Mathematics. It is now announced in the department of Agriculture.

(3) Bachelor of Letters established in 1869 , and discontinued I880; re-established I882 as Bachelor of Letters of the University of Virginia (B. Let. Univ. Va.); requirements, graduation in Latin, Greek, and Moral Philosophy, and in the Modern Languages, or in English, or in Historical Science. Discontinued 1889 .

(4) Bachelor of Philosophy of the University of Virginia (B. Ph. Univ. Va.); requirements, graduation in any three of the following subjects: Latin, Greek, both French and German, English, Historical Science and Moral Philosophy; and, also, in any two of the following: Pure Mathematics, Natural Philosophy, General Chemistry, and Natural History and Geology. Established 1883 , discontinued I889.

(5) Doctor of Letters of the University of Virginia (D. Let. Univ. Va.); requirements, the degree 
of Bachelor of Letters and graduation in any two of the Literary Schools. Established I883, discontinued I889.

(6) Doctor of Science of the University of Virginia (D. S. Univ. Va.) ; requirements, the degree of Bachelor of Science and graduation in any two of the scientific schools. Established I883, discontinued I889.

(7) Doctor of Philosophy of the University of Virginia (Ph. D., Univ. Va.). Established I883. The candidate for this degree must be in possession of a satisfactory baccalaureate degree, must spend at least three years in graduate work, a portion of which may be done in an institution of similar grade to the University, and must write a dissertation which is satisfactory to the faculty.

The above enumerated degrees, together with that of Master of Arts, have constitued the highest academic honors of the University and are known as titled degrees. There were at one time three forms of untitled degrees, viz: a certificate of distinction (on paper), a certificate of proficiency (parchment), and a diploma of graduation. The certificate of distinction was discontinued. It was conferred upon one who had passed a satisfactory examination (three-fourths of the total value of the questions) at any intermediate or final examination. A certificate of proficiency was awarded to one who had passed a satisfactory examination on any of the following subjects: Anglo-Saxon, Early English, Modern English, Rhetoric and English Literature, General History, Political Economy, and Science of Society, Logic, Philosophy, Junior and Intermediate Mathematics, Junior Physics, Agricultural Chemistry, Mineralogy, Geology, Botany, Physi- 
ology, Human Anatomy, Medical Jurisprudence, Pharmacy, and Constitutional and International Law. As far as the catalogues show the last proficiencies awarded were conferred on June I2, I895.

The diploma of graduation is still conferred on one who has satisfactorily completed the work for the M. A. course, as, for instance, in Latin, Greek, Mathematics, etc. Each school confers the untitled degree of graduate on completion of the entire course taught in that school. "A student who has received this diploma of graduation in Latin, say, is entitled to call himself a graduate of the University of Virginia in Latin."

To the above untitled degrees of early origin and long continuance is to be added the pass-certificate which is awarded to one who accomplishes satisfactorily the first or second year of collegiate work prescribed for the school in question.

The elective system has not been generally understood, and its existence in other American universities has been claimed in ignorance of what it really is. Part of it is the negation of the class system and the refusal to admit time (except as a minimum) as a consideration in awarding degrees, titled or untitled. The only exactions are proper preparation and enough classes to employ the student. When he becomes a candidate for a titled degree he must conform to the requirements; he is not allowed to elect his own combination of studies, although he may exercise choice as to the order in which he will take up the required subjects.

A brief sketch of the evolution of the schools will exhibit to some extent the development of the University. By Mr. Jefferson's organization the work in literature and science was distinctly assigned- 
the literary subjects to the Schools of Ancient Languages, Modern Languages, and Moral Philosophy; the scientific to the Schools of Mathematics, Natural Philosophy, Natural History, and Anatomy and Medicine. The founder did not consider the School of Anatomy and Medicine one to afford professional training.

The Literary and Scientific Schools have been expanded from seven to fourteen. At present the literary are the Schools of Latin, Greek, Teutonic Languages, Romanic Languages, English, Literature, Historical and Economical Science, Moral Philosophy, and the Curry School of Education; and the Scientific are the Schools of Mathematics, Applied Mathematics, Practical Chemistry, Analytical Chemistry, Natural History and Geology, and Biology.

It is instructive to follow the expansion, and the incidental changes, in detail.

\section{Academic Department.}

ANCIENT LANGUAGES:

The School of Ancient Languages, established in I825, with Professor George Long as the first incumbent of the chair, consisted of Latin and Greek, and, until 1856, the work of teaching these languages, and Roman and Greek history and literature, was assigned to but one person. Professor Long's service extended from 1825 to 1828 , with a short period of absence in the summer of the first of these years, when he returned to England to receive his fellowship at Trinity. During this furlough Professor Thomas H. Key, of the School of Mathematics, without neglecting the duties of his own chair, taught acceptably all of Mr. Long's classes. 
In $1828 \mathrm{Mr}$. Long was invited to the University of London, just established, and was regretfully released by Mr. Madison, the rector, to whom Lord Brougham had addressed an urgent letter on the subject. The retiring professor was asked to suggest a successor, and it was expected that he would indicate some fellow-countryman. On the contrary, he nominated Gessner Harrison, one of the first students who had graduated in his own school and had recently attained his majority. The Board accepted the young Virginian, and the University profited by his thirty-one years of faithful service.

The School of Ancient Languages was divided in I 856 and became the School of Latin and the School of Greek.

Professor Harrison filled the chair of Latin for three years, I856-59, when he resigned, and was succeeded by Lewis Coleman ( $1859-61$ ), who was fatally wounded at Fredericksburg in 1862 . Basil L. Gildersleeve taught through the sessions and fought through the summers of $1861-65$, and was succeeded in 1865 by William E. Peters, who continued at the head of the school until 1902, when he became Professor Emeritus. Thomas Fitzhugh followed him and is the incumbent.

The School of Greek, as a separate chair, dates from 1856. Professors: Basil L. Gildersleeve, I856-76; $;^{1}$ Thomas R. Price, I876-82; W. H. Wheeler, I882-87; Milton W. Humphreys since I887.

\footnotetext{
${ }^{1}$ Dr. Gildersleeve was twenty-five years of age when he was made professor of Greek and Hebrew-for Hebrew was then attached to the chair of Greek-but he was already a $\mathrm{Ph}$. D. of Göttingen. In I876 he was called to the Johns Hopkins University. Professor Price came to the University from Randolph-Macon, and in 1882 went to Columbia.
} 


\section{MODERN LANGUAGES :}

George Blaettermann was the founder of the School of Modern Languages (I825), in which he held himself prepared to teach almost any modern tongue. He retired in 1840 . Other professors were Charles Kraitsir, ${ }^{2}$ I84I-44; Dr. Maximilian Schele De Vere ${ }^{3}$ I844-95; Joachim Reinhard, acting professor of French and German, I895-96; James A. Harrison, English, French and Spanish, I896-98; Romance Languages, I898-99; Teutonic Languages since I898; William H. Perkinson, German and Italian, I896-98; Richard H. Wilson, Romanic

${ }^{2}$ Dr. Blaettermann's successor, Dr. Kraitsir, was a native of Hungary, and was educated at Pesth and Vienna. After a brief practice of medicine he joined the Polish patriots in their effort to throw off the Russian yoke, and served as a surgeon at Warsaw and in the field. His life was migratory for years, during which he sojourned in Germany, Italy, France and Belgium. The languages of all those countries he spoke fluently, and he was regarded as a remarkable linguist. Dr. Kraitsir retired from the University in 1844 and eventually made his home in Morrisania, New York.

${ }^{8}$ Dr. Schele was a native of Sweden, but at eight years of age his father's family went to Southern Germany, where he grew to manhood. He studied at Berlin and Bonn, receiving his doctorate from the former. The following year Greifswald gave him the degree of Juris Utriusque Doctor. After a short term in the military and later in the diplomatic service of Prussia he came to America and spent a year in travel, and in study in Boston, where he met Ticknor and Longfellow. He retired from his chair after $5 \mathrm{I}$ years of service and died at the Providence Hospital in Washington May Io, 1898. The funeral was held from Christ Church, Navy Yard, and the interment in Rock Creek Cemetery. The pall-bearers were Holmes Conrad, Leigh Robinson, Charles L. Bartlett, O. W. Underwood, John Sharpe Williams, W. A. Jones, William B. Mathews, and E. I. Renick.

Dr. Schele did much for the University. His work as an author covered a wide field-philology, sociology, fiction. He compiled and published a semi-centennial catalogue which stands first among books about the University for the varied and important information it contains. 
Languages since I899. A foreigner founded the school, and his successors were foreign born until 1896.

The School of Modern Languages was divided at the beginning of the session of $1898-99$ into the School of Teutonic Languages, of which Dr. James A. Hiarrison has since been professor, and the School of Romanic Languages, Dr. Richard $\mathrm{H}$. Wilson professor.

MaTHEMATICS :

Thomas Hewitt Key organized the School of Mathematics in I825, and remained at its head until 1827. He seems never to have been satisfied in America, certainly not after the disorders of October, 1825. Together with Mr. Long he tendered his resignation on that unhappy occasion, but it was not accepted. During the eighteen months following he twice endeavored to resign, and the last time entered a plea of failing health in the Virginia climate. $\mathrm{He}$ was released then, and his successors have been Charles Bonnycastle, I827-40; J. J. Sylvester, 1840-4I ; Edward H. Courtenay, I842-53; Albert T. Bledsoe, I854-63; ${ }^{4}$ Robert T. Massie, I86I-62; Francis H. Smith, I863-65; Pike Powers was professor by temporary appointment from I840 to I84I and again from 1842 to 1843 , and Alexander Nel-

- One of the most gifted and aggressive of men was Dr. Alfred Taylor Bledsoe. Previous to his removal to the University he was professor of mathematics in the University of Mississippi. He was a contemporary of Jefferson Davis and Robert E. Lee at West Point, and as a lawyer practiced in the same courts in Illinois as Lincoln and Douglas. $\mathrm{He}$ went to Europe during the war at Mr. Davis's request to have the use of the library in the British Museum in preparing his book, "Is Davis a Traitor?" 
son from 1853 to 1854 ; Charles S. Venable, I865-96 (Emeritus, I896-I900); W. H. Echols since 1896 ; James M. Page, adjunct, $1896-98$, and asociate I898-I902, professor since 1902 .

Applied Mathematics:

The School of Applied Mathematics was established in 1867. Professors: Leopold J. Boeck, I867-75; William $M$. Thornton, adjunct, $1875-83$, professor since I883; William M. Echols, adjunct, I89I-96.

\section{CHEMISTRY :}

The School of Chemistry was organized in 1825 by Dr. John P. Emmet (1825-42). Other professors: Robert E. Rogers, I842-52; J. Lawrence Smith, I852-53; Socrates Maupin, I853-7I ; John W. Mallet since 1872 .

Chemical Technology and Agricultural Science ( I867)-Professor: John W. Mallet, I867-68. changed to-

Analytical, Industrial, and Agricultural Chemistry (I868)-Professor: John W. Mallet, I868-72. Changed to-

General and Applied Chemistry (I872)-Professors: John W. Mallet, I872-84; F. P. Dunnington (acting), 1884-5. Changed to-

General and Industrial Chemistry (1885)-Professor: John W. Mallet since 1885.

Analytical and Agricultural Chemistry (1885)Professor: F. P. Dunnington since 1885 .

Natural Philosophy :

The School of Natural Philosophy dates from I825 and was organized by Charles Bonnycastle, 
who was transferred to the School of Mathematics on the retirement of Professor Key. Other professors: Robert M. Patterson, 1828-35; William B. Rogers, 1835-53; Francis H. Smith, since 1853.

\section{Natural, History and Agriculture:}

Samuel Miller of Lynchburg gave to the University in trust one hundred thousand dollars for the establishment of a department of scientific and practical agriculture. In September, 1869, on the nomination of the Miller Board of Trustees, John W. Mallet was elected professor of analytical and agricultural chemistry and Leopold J. Boeck professor of mechanics and engineering as applied to agriculture, and the department was put into effect. In the following July was established the School of Natural History and Experimental and Practical Agriculture (I870)-John R. Page, professor, 1872-79. The school was then rearranged, and became Zoology, Agricultural Botany and Agriculture (I879)-John R. Page, professor until I887, when another readjustment was effected, under the title of the School of Biology and Agriculture (r887)-Albert H. Tuttle, professor since I888.

Natural History and Geology (I879)-William M. Fontaine, professor since 1879 . In this year W. W. Corcoran of Washington, a generous friend of the University, gave $\$ 50,000$ to endow a school of this character, and Geology-heretofore attached to the School of Natural Philosophy-and Natural History, and a part of the department of Agriculture were combined in one school. 
Moral, Philosophy:

The School of Moral Philosophy, dating from I825, has had but three professors: George Tucker, I825-45; William H. McGuffey, I845-73; Noah K. Davis since 1873 .

\section{History AND LiTERATURE:}

The School of History and General Literature was established in 1857 , with George Frederick Holmes as professor. In I882, Political Economy, which had been attached to the School of Moral Philosophy since George Tucker had introduced it in the early years of his professorship, was substituted for Literature, which was assigned to Professor Garnett. Thus arranged it was called the School of Historical Science. Richard H. Dabney was adjunct professor 1889-97. In I897 Professor Holmes died and the School of Historical and Economical Sciences was established, with Dr. Dabney professor. He is still the incumbent.

In 1882 the School of English Language and Literature was established, James M. Garnett, professor until 1893. In that year the School of English Literature was arranged as a separate department, Charles W. Kent, professor. This school, known as the Linden Kent Memorial School of English Literature, was founded upon a liberal gift of Mrs. Kent as a memorial to her late husband. ${ }^{5}$

' Linden Kent came to the University as a student from service as a Confederate private, having enlisted at sixteen. $\mathrm{He}$ was first a student in the academic department and then in the law, and was graduated in 1870 with the degree of B. L. His fellow-students had conferred upon him several honors, among them an editorship of the University Magazine, and he won the Debater's medal in the Washington Society. 
This organization of the School of English Literature left English Language as an independent school and it continued so until 1896 , when it was transferred to Professor Harrison, who at that time had French and Spanish. Two years later it became a part of the School of Teutonic Languages.

Practical, Astronomy :

The School of Practical Astronomy was founded in I88I on a gift by Leander J. McCormick, a native of Virginia, resident in Chicago, and on supplementary contributions by William $\mathrm{H}$. Vanderbilt and others. Professor Ormond Stone, the first incumbent, has been director since 1882 .

\section{Professional Schools.}

The professional schools, named in the order of establishment, are those of Medicine, Law and Engineering.

For two years at least the School of Medicine had a cultural purpose only, but in 1827 it was enlarged. Dr. Dunglison, the original head, was made professor of physiology, theory and practice of medicine, obstetrics and medical jurisprudence; Dr. Emmet, chemistry and materia medica, and Dr. Thomas Johnson, demonstrator of anatomy and surgery. The following scheme exhibits the development of the School of Medicine from its foundation to the present time. The dates in parentheses indicate the time of inaugurating the particular arrangements to which they are attached.

DEPARTMENT OF MEDICINE:

Medicine (1825)-Professors: Robley Dunglison, 1825-33; Alfred 'T. Magill, I833-37; R. 
E. Griffith, I837-39; Henry Howard, 1839-67. Changed to-

Medicine and Obstetrics (1867)-Professor: James F. Harrison, I867-79. Changed to -

Medicine, Obstetrics, and Medical Jurisprudence (1879)-Professors: James F. Harrison, I879-86; William C. Dabney, I886-90. Changed to-

Obstetrics and Practice of Medicine (1890)Professors: William C. Dabney, I890-94; Augustus H. Buckmaster, acting, 1894-95, professor I895-6. Changed to-

Gynecology, Obstetrics, and Practice of Medicine (1896)-Professor: Augustus H. Buckmaster, I896-99. Changed to-

Gynecology, Obstetrics, Surgical Diseases, and Abdominal Surgery (1899)-Professor: Augustus H. Buckmaster, I899-1905.

Pathology and Hygiene (1893)-Instructor: John Staige Davis, I893-94; adjunct, I894-99. Changed to-

Pathology (I899)-Professor: John Staige Davis, I899-I900. Changed to-

Pathology and Practice of Medicine (I900)Professor: John Staige Davis since 1900.

Biology (1887)-Professor: Albert H. Tuttle since $\mathrm{I} 888$.

Bacteriology (r89r)-Professor: Albert $\mathrm{H}$. Tuttle since I89I; J. Carroll Flippin, adjunct since I904.

Anatomy and Surgery (1827)--Demonstrator: Thomas Johnson, I827-3I; professor, I83I-34; Augustus L. Warner, 1834-37; James L. Cabell, I837-49; demonstrator, John Staige Davis [Sr.], I845-49; lecturer and demonstrator, I849-53; lecturer on anatomy, materia medica, and therapeutics, 
I853-56; William B. Towles, $1872-85$; acting professor, I885-86; professor, I886-93; demonstrator, William G. Christian, I889-93; professor, 18931905 .

Comparative Anatomy, Physiology and Surgery ( 1849)-Professor: James L. Cabell, I849-6r.

Anatomy, Materia Medica, Therapeutics and Botany (I856)-Professor: John Staige Davis, 1856-6r. Changed to-

Anatomy and Materia Medica (I86I)-Professors: John Staige Davis, I86I-85; William B. Towles, acting, I885-86; professor, I886-93.

Physiology and Surgery (I86I)-Professors : James L. Cabell, I86I-89; Paul B. Barringer, I889-94. Changed to-

Physiology and Materia Medica (1894)-Paul B. Barringer since 1894 .

Hygiene-Lectureship established in 1898 , William A. Lambeth, incumbent; taught theretofore by Dr. John Staige Davis, beginning 1893. This was expanded in r 90 I into the lectureship of hygiene and materia medica. The following year the lecturer, Dr. Lambeth, was made adjunct professor, and in 1903 professor.

The degree of M. D. was conferred in 1838 for the first time; the recipients were Gessner Harrison of Rockingham, George W. McCulloch of Albemarle, and Thomas J. White of Florida.

DEPARTMENT OF LAW :

The frequent rearrangements of subjects in the medical department has not entirely obliterated the original distinction of schools. In the Department of Law, however, the two schools, in which the 
original one was divided in 1851 , have become simply a number of classes.

John Tayloe Lomax, the first professor of law, entered upon his duties July, 1826, and retired four years later. John A. G. Davis, his successor, was assassinated in 1840 , and the work of the school for that year was completed by Nathaniel Pope Howard. Mr. Howard was killed in the capitol disaster in Richmond, April 27, $1870 .^{6}$

Judge Henry St. George Tucker was incumbent from I84I to I845, when he resigned on account of failing health. ${ }^{7}$ Then began the remarkable career as a teacher of law of John B. Minor, which extended to the year of his death, I895.

In I85 I James P. Holcombe entered the service of the School of Law as adjunct, and in I854 became professor. At that time he was one of the most distinguished men in the faculty. He rightly interpreted the signs of the times as portending a terrible civil conflict, and became a leader of the thought that solidified the South. As an orator at once persuasive and passionate, he swayed the opinions of all who heard him, and not only almost but fully convinced them that there was but one side to the tremendous controversy. His connection with the University ended in I86r, in which year he was a

'A footnote to the Richmond Mayoralty Case (Grattan, xix, 673) tells the story of the collapse of the floors of the building and the ensuing horror, and says of Howard that he was of "extensive and varied learning which he as anxiously concealed as others seek to make theirs known; accurate in all things to a proverb, with the unswerving integrity and the purity of life which secured to him the confidence and regard of all who knew him."

"John M. Patton was appointed professor of law July 4, I845. He seems to have declined, although there is no record. Mr. Minor was unanimously elected July 28. 
member of the Secession Convention. The Confederacy claimed his service in Congress and in confidential relations until its collapse in 1865 .

Holcombe was succeeded by Stephen O. Southall, I 866-84; and he by James H. Gilmore, I885-96.

William Minor Lile entered the faculty in 1893 , becoming the colleague of Professors Minor and Gilmore. Upon the death of Mr. Minor in 1895, Walter D. Dabney succeeded him, but death claimed him after three years of service (1899), and Charles A. Graves has filled the chair since that year. There have been two assistants or instructors-John B. Minor, Jr., I890-93; Raleigh C. Minor, I893-95. The latter was made adjunct $1895-99$, and professor since the last named date.

The degree of Bachelor of Law was conferred for the first time in July, 1829, on Charles L. Mosby of Powhatan and Nathaniel Wolfe of Charlottesville.

Outside influences which affected the graduate have forced the element of time into the conditions precedent to the conferring of the degrees in Law and Medicine. Two years are required in residence for the degree of Bachelor of Law, and four for that of Doctor of Medicine.

\section{DEPARTMENT OF ENGINEERING :}

The present School of Engineering had its beginning in a small way in 1867 , doubtless through the efforts of Professor Leopold J. Boeck, ${ }^{8}$ whose con-

\footnotetext{
${ }^{8}$ Leopold Jules Boeck was a native of Culm, Poland, and was forty-four years of age when he reached the University in I866 after an adventurous career. The University of Berlin conferred upon him the degree of Doctor of Philosophy, immediately after which he became involved in the Polish Revolution of I849. Its failure made him a fugitive from his own country, and he took part in the revolution and uprising
} 
nection with the University dates from the previous year.

At first the chair in Professor Boeck's charge was called the School of Applied Mathematics, Engineering, and Architecture. The entire work of the school from I 867 to 1875 was done by the professor with assistants during two of the eight years. In I875 the school was known as the department of Applied Mathematics and Civil Engineering, William M. Thornton succeeding Boeck as its head in the grade of adjunct professor.

In 1882 the Department of Engineering was established with this faculty:

Natural Philosophy, Professor Francis H. Smith;

Mathematics, Professor Charles S. Venable;

General and Applied Chemistry, Professor John W. Mallet;

Natural History and Geology, Professor William M. Fontaine;

Analytical and Agricultural Chemistry, Professor F. P. Dunnington;

Mathematics applied to Engineering, Adjunct Professor William M. Thornton.

The constitution of this department has not been changed since 1882 , but its scope has been greatly

in Hungary. He soon won the confidence of Kossuth and the General sent him as envoy from Hungary to Turkey to ask assistance. Instead of being aided he was imprisoned, but after two years he was placed on the United States steam frigate Mississippi and sent to Paris. There he fell in with Victor Hugo and Victor Cousin. His anti-Napoleon sentiments and his penchant for revolutions put him under suspicion, and when Hugo was thrown into prison Boeck was ordered to leave France. Reaching New York he established a school in that city, which was broken up by the civil war. Eventually he came to the University, where his early labors resulted in one of the first cases of technical and industrial education in universities. He died in Philadelphia in 1896. 
enlarged. Since that date an additional full professor has been appointed in the School of Pure Mathematics, the adjunct in Applied Mathematics advanced to full professorship, and three adjunct professors attached to the Department of Engineering, who have charge of the purely technical courses respectively in civil, mechanical and electrical engineering, the professor of Applied Mathematics having temporary charge of the course in Mining Engineering. From the beginning of $\mathrm{Mr}$. Thornton's connection with the University in 1875 he has been in a large sense the School of Engineering, and its remarkable growth and success would seem to approve his policies .

The degrees conferred in this department are those of Civil Engineering, instituted in 1868, and Mining Engineering I868, Mechanical Engineering, 1892, and Electrical Engineering, 1893. The degree of Civil and Mining Engineering was conferred from 1868 to 1879 . 


\section{CHAPTER XXVII}

THE BEGINNING OF AN ERA

New Educational, Departure-Unusual, Features, Many OF THEM AdOPTED BY OTHER INSTITUTTONS-ChaNGES, PARTICULARLY IN FORM OF GOVERNMENT-WHAT THEY MEAN, AND Why THEY WERE MADE-IMMEDIATE. EFFECT-LOOKING FORWARD.

When the University was established there was no institution in the world that closely resembled it. With two exceptions, the others had proceeded from the purse of some rich churchman, or from the treasury of the State as the issue of its union with the church, or from the collection of some denomination whose faith sought educational aid in its propaganda; but the University of Virginia came from the brain of one man, and that man's purpose in education was the new one to safeguard the liberties of his country by increasing the moral and intellectual stature of the citizen.

In many respects a great chasm separated it from Harvard, Princeton, and the other dominant institutions eighty years ago-a chasm equal to the difference between accepted methods and a vast experiment dealing with many ideals and tendencies. Then this University stood alone in its refusal to subject its matriculates to what its founder regarded as the harmful tyranny of the curriculum, in the independence of its schools, in the liberty of its students to select their own studies, in the disregard of time, except a minimum, as an element affecting the fortunes of a candidate for any degree, in the ab- 
sence of entrance examinations, in the requirement of examinations consisting of written answers to written questions, which subjected every student to the same test, and the grading of the examinee on his written answers only; and in the fact that all of its degrees must be earned by resident study. It is peculiar in other important respects. For a rather long time it was alone in America in teaching together the language and the history of a people; and it was the first to dare to dignify the study of modern languages with an independent chair filled by a scholar, to make English its official language, and constitute it the medium through which its honors have always been declared. In these and many other avenues that were new eighty years ago Jefferson set the feet of the scholars of his Univer- . sity, and they journeyed without companions for many long years; at the same time he pointed out fields which his University has not occupied effectively; among them the important ones which have since been entered by the military academies, the technological schools, and the agricultural and mechanical colleges, which have developed so remarkably during the last twenty years.

Today the chasm between the University and the other dominant institutions is not so wide as it was even fifty years ago, but its strength is still derived from the old sources; its old ideals continue vital. There have been changes, but they were mainly in the nature of rearrangements and expansion of existing and essential conditions. Something has been imported; but more has been exported, to the infinite advantage of other American universities. The gifts Virginia has bestowed have contributed far more than those she has received to the formation 
of a resemblance between Jefferson's institutional creation and those of like age and eminence. There has been less change of fundamentals here than elsewhere.

The most significant departure was the abandonment of the Jeffersonian system of faculty government through the medium of a chairman. ${ }^{1}$ Even in the lifetime of Mr. Jefferson, and among his most intimate friends, there must have been a sentiment in favor of substituting a presidential government, for it is scarcely probable that, in the absence of a rather strong conviction of the kind, the Visitors would have cared to create the presidency in defiance of the rector's wishes, even with the laudable purpose of securing Mr. Wirt as professor of law. That the chairmanship, with a presidential salary attached, was not offered to the distinguished lawyer as an inducement to accept the professorship seems to show that the office of chairman was regarded as inferior in dignity to that of president.

The presidency was often thought of as offering an avenue of escape from administrative perplexities, and it was pondered for other reasons also. In I846 it was warmly discussed by the board as a means of correcting errors which some of the Visitors believed had been made in the chairman's effort to deal with the problems of discipline so painfully accentuated by the disorders of the current session. ${ }^{2}$ Beyond Mr. Rives's advocacy of the presidency the board's minute-book tells little, but it is certain that if the office had been created at that time the action would have been defended by alleging the failure of

${ }^{1}$ For a list of the chairmen see p. 375 .

${ }^{2}$ See p. 162 . 
faculty administration to achieve a reasonably stable discipline.

The era in which the usefulness and the very life of the institution were more than once at the mercy of the turbulent spirits who paced the arcades and colonnades in the first quarter of a century after the death of the founder was now at an end. The noble example and patient efforts of great teachers had been rewarded by the growth among student ideals of a manliness which put aside forever the inexcusable lawlessness of past years. But other problems arose. The war came on and left its scars upon a people, and discovered a nation's heroes. Some of the Visitors perhaps, certainly many of the alumni, urged that the chief of these heroes, Robert E. Lee, be made president. Perhaps it was a simple impulse of homage-an grand homme la patrie reconnaissante. No doubt Mr. Jefferson ruled the Visitors from his urn, for they abandoned the movement.

The sentiment would not down, however, and in I897 it was so strong in the Board of Visitors that an election was prevented only by the breaking of the quorum. From that time until June, 1904, the question was constantly before the Visitors and was debated wherever and whenever alumni met. The reasons usually given for opposing the change were that it would violate the fundamental theory of the organization of the University which had worked successfully for seventy years and vindicated the wisdom of its framer; that it would be expensive and experimental; that it would subtract from the independence of the professor by subjecting him, to some extent, to the will of the executive; that the professor would necessarily descend from the high estate awarded him by the founder which made him 
in dignity a senator who did not have to regard the rescripts of any emperor or president; that it would subvert the theory that the University is a collection of schools, each presided over by a distinguished and independent master, and substitute a monarchy for the republic of letters.

The advocates of the presidency were convinced that the combined duties of the offices of chairman and of professor were beyond the competency of one man. They did not assail the democratic purpose of Mr. Jefferson in ordaining this office, nor did they question the soundness of the principle of individual equality and independence upon which it was partly based. But changed conditions, they said, emphasized the fact that the professor who, in this day, is charged with official duties in addition to those appertaining to his chair was no longer on an equality with his colleagues who were not so burdened. It could not be affirmed, they admitted, that the chairmanship had not always and successfully met the requirements of the institution, but that form of government had not so commended itself that many other universities had adopted it, and the institutions which had done so soon abandoned it. Problems then existing in the educational world, in the opinion of the advocates of the presidency, demanded such a change in Mr. Jefferson's peculiar government as would give it an executive who was unhampered in the discharge of his administrative duties, who was free to familiarize himself with the higher education as imparted in the best institutions of the world, to suggest wise administrative changes, to visit the various sections of the country and arouse the interest of the alumni, and to do a multitude of things which would be impossible to a chair- 
man upon whom were laid also the burdens of a professorship.

Nobody alleged a failure of the University in its discipline or in the inspiration, method, and scope of its work. Pedagogically it had always been sufficient, and it had been efficient in government for half a century. If the Visitors contemplated the presidency with occasional misgiving the uneasiness was on the score of the jealously guarded standard requisite for the degrees, and the entente cordiale which had existed between faculty and students for fifty years. So strong was this feeling of uncertainty that the committee appointed by the Visitors "to consider the question of creating an executive department of the University" reported in April, I897, in favor of a chairman of the faculty whose duties should not extend beyond the subjects of discipline and instruction. All other administrative affairs were assigned to a president.

The greatest obstacle in the way was the conservatism of some of the members of the board and of a large number of the alumni with whom the weight of Mr. Jefferson's views was very great. ${ }^{3}$ The Visitors decreed a change of government, and under authority granted by the legislature an "executive head" was appointed June I4, I904, in the person of Dr. Edwin A. Alderman, who was inaugurated April I3, I905.

After all, the chairmanship was less fundamental to the University as an educational institution than to the political philosophy of the founder. As it came from his hands, the University, in its vital concerns as a teaching and constructive force is, under

${ }^{3}$ See p. II2. 
the presidency, as invulnerable to degenerating influences as it would have continued under the chairmanship. Its history has shown that its two great problems were discipline and standards of instruction. The increasing dignity of young manhood has largely removed the first. The maintenance of the standards has been accomplished thus far by the sacrifice of opportunities for the material prosperity which other institutions have achieved through constantly lengthening rolls of students. There have been scores of royal roads to learning constructed from the preparatory schools to the baccalaureate prizes of many colleges, and the slow jogging of the old days which gave time for observation and promoted good health and digestion has given place elsewhere to rapid transit, both elevated and underground, which will, in turn, yield to the pneumatictube methods of educational specialists. Whether the University will substitute specialization for scholarship depends on chairmanship or presidency less than on the continued devotion of its Visitors and alumni to the ideals which have made it probably the most respected institution in America.

The presidency has inaugurated a new era in the life of the University. The State, which has contributed to its chief institution of learning, since I865, much less than individuals have done, manifests a liberal spirit by generous aid, and benefactors have added to its endowment in two years an aggregate almost as large as the total of the gifts bestowed from the close of the civil war until 1904. The attendance of students is the largest in the history of the institution, and the matriculates are better prepared, and are better classed in the work they are doing. 
Internally, the line of separation between the two chief divisions-the university and the college-is more sharply drawn, or, if not so, it appears more distinctly. Other gains are a positive initiative, an increase in teaching force, and expansion in various directions; and further advancement is planned for early realization.

Altogether, the University of Virginia was never more fortunate in its faculty and officers, and never faced a period of more promise in upbuilding ways than the era upon which it has just entered. More strikingly than ever before it is "the lengthened shadow of one man." 


\section{APPENDIX}

\section{I \\ The University of Virginia and The Con- FEDERACY}

(See pages 199-219.)

The following is a partial list of the men furnished to the civil and military service of the South by the University. The figures are the dates of entrance as students :

With the rank of major-general: L. M. Laws '36, John Bankhead Magruder '25, George W. Randolph ' 37.

With the rank of brigadier-general: Richard L. T. Beale '37, John C. Carter '54, Philip St. George Cocke '25, Philip Cook, Jr. '39, Richard B. Hubbard, Jr. '51, Robert D. Johnston '60, James H. Lane '56, John R. Liddell '32, Elisha F. Paxton '48, William H. Payne '48, Davidson B. Penn '56, Lucius E. Polk '5o, Carnot Posey '36, Roger A. Pryor '46, William A. Quarles '45, Paul J. Semmes '33, John W. Shivers '56, Robert Q. Taliaferro ' 54 , William Terry ' 46 , Robert Toombs '28, James A. Walker '54, Williams C. Wickham '37, Louis T. Wigfall '34, William $\mathrm{H}$. Young '59.

With the rank of colonel: Leopold L. Armant '55, William Roane Aylett '50, John B. Baldwin ' 36 , Robert J. Barrow '34, William Randolph Berkeley '59, Pinckney Downie Bowler '55, Alexander J. Brown '55, Hamilten A. Brown '59, J. Thompson Brown '52, J. Wilcox Brown '5r, William P. Burwell '48, William Byrd '5I, William R. Calhoun '44, George W. Carr '36, Thomas H. Carter '50, H. G. Charles '30, R. E. Chew '52, James V. Chilton '6o, Richard A. Claybrook '36, James Cochran '48, Richard Dillard '39, Robert P. Duncan '59, William Elliott '56, J. P. Fitzgerald '57, William Fort '51, Edward P. Fristoe '52, Lucian C. Gause '53, Jonathan C. Gibson '50, William E. Green '45, Roger Gregory '49, Benjamin Gunter '47, Peter Hairston '53, Bolling Hall, Jr. '59, John W. Hambledon '54, Daniel $\mathrm{H}$. Hamilton '34, George W. Hansbrough '46, Julian Harrison '44, Randolph Harrison '46, Hilary A. Her- 
bert '54, Thomas H. Hobbs '47, E. Lafayette Hobson '52, John C. Humphreys '40, Daniel R. Hundley ' $5 \mathrm{I}$, Irwin P. Jones ' 32 , Egbert J. Jones '39, James F. Jones '39, Theodore A. Jones '52, Hilary P. Jones '52, Delaware Kemper '49, Franklin W. Kirkpatrick ' 55 , William C. Knight ' 36 , Edward P. C. Lewis '54, William M. Lowe '60, John Bowie Magruder '56, Charles Marshall '46, William J. Martin '5I, Rawley W. Martin '55, Richard L. Maury '57, James M. Mayo '59, John D. Morris '30, John S. Mosby '5o, William P. Munford '35, William Munford '47, Angus W.' McDonald '48, Edward F. McGehee '35, Alexander D. McNairy '60, Kirkwood Otey '49, Henry T. Parrish '52, Henry Clay Pate '48, Samuel B. Paul '46, William Johnson Pegram '6o, John E. Penn '59, William A. Percy '55, William E. Peters '50, Robert L. Y. Peyton '42, John T. L. Preston '28, R. O. Reynolds '53, Alfred L. Rives '48, Henry M. Rutledge '58, William C. Scott '29, Pliny Sheffield '57, Charles R. Skinker '57, James H. Skinner '42, Thomas Smith '56, Thomas L. Snead '46, Ezra E. Stickley '64, John C. Summers '59, William B. Tabb '59, Tazewell Taylor '26, Lawrence B. Taylor '36, John H. Thomas, Jr. '59, John T. Thornton ' 43 , Stephen D. Thurston ' 51 , Harrison B. Tomlin '33, Thomas H. Watts ' 37 , Powhatan B. Whittle ' 47 , William B. Wooldridge ' 45 , William O. Yager ' 53.

They likewise took conspicuous and important roles in the civil affairs of the Confederate States. In the Provisional Congress which assembled at Montgomery, Alabama, in February, 1861, seven members had been students at Virginia. They were :

Alabama, David P. Lewis '37, Richard W. Walker '38.

Georgia, Robert Toombs '28.

Louisiana, Alexander de Clouet ' 56 .

Mississippi, Wiley P. Harris ' 36 .

South Carolina, William W. Boyle ' 36.

Texas, Louis T. Wigfall ' 34 .

Among the additional members sent to that Congress upon its assembling at Richmond in July, I86I, were seven alumni, namely:

John W. Brockenbrough '25, Robert M. T. Hunter '26, William B. Preston '25, Roger A. Pryor '46, Robert E. Scott '25, James A. Seddon '35, Augustus E. Maxwell '36. 
In the Confederate Senate there were ten:

Robert M. 'T. Hunter, Virginia, president, '26, Clement C. Clay, Jr. Alabama, '37, Richard W. Walker, Alabama, '38, Augustus E. Maxwell, Florida, '36, John W. C. Watson, Mississippi, '28, Robert L. T. Peyton, Missouri, '42, James L. Orr, South Carolina, '39, Louis T. Wigfall, Texas, '34, William B. Preston, Virginia, '25, Allan 'T. Caperton, Virginia, '28.

Eighteen former students of the University were members of the first and second Congress of the Confederate States, from the 22d of February, 186r, to the overthrow of the Confederacy in April, I865:

Alabama, James S. Dickinson '34.

Georgia, David P. Lewis '37.

Kentucky, Robert J. Breckinridge ' 37.

Louisiana, Lucius J. Dupre '39.

Mississippi, Henry C. Chambers ' 39.

Missouri, Caspar W. Bell '39, William M. Cooke '40, Thomas L. Snead ' 46.

North Carolina, John A. Gilmer '59.

South Carolina, Louis M. Ayer '39, William W. Boyce ' 36 .

Virginia, John M. Baldwin '36, Muscoe R. H. Garnett '38, Thomas S. Gholson '26, James P. Holcombe '36, Frederick W. M. Holliday '34, Roger A. Pryor '46, Williams C. Wickham '37.

President Davis found five of his Cabinet officers among the alumni of the University:

Secretaries of State, Robert M. T. Hunter of Virginia '26, and Robert Toombs of Georgia '28.

Secretaries of War, George Wythe Randolph '37, and James Alexander Seddon '35, both of Virginia.

Attorney-General, Thomas H. Watts of Alabama '37.

One of the two Confederate Commissioners to Europe, James M. Mason, had been a member of the Board of Visitors of the University, and his secretary, James Edward McFarland, was a student in I843. 
In 1864 a commission of three persons, "eminent in position and intelligence," was appointed to visit Canada with a view to negotiation with such persons in the North as might be relied upon to aid in the attainment of peace. President Davis named Clement C. Clay of Alabama, James P. Holcombe of Virginia, and Jacob Thompson of Mississippi, for this mission. Clay and Holcombe were alumni of the University. ${ }^{1}$ There seems to be some uncertainty as to the membership of this commission. Greeley in his "American Conflict" (Vol. II, p. 664) mentions Clay, Holcombe, and George N. Saunders, and believed that Clay and Holcombe "had full powers from Richmond." Mr. Holcombe's daughter, Mrs. Ada Holcombe Aiken (Alumni Bulletin, Vol. III, p. 85) coincides with Mr. Greeley, and yet it seems from Mr. Holcombe's letter to Secretary Benjamin (Series 4, Vol. II I, 583, War of the Rebellion) that the former was in Canada, not as a colleague of Clay and Thompson, but as an agent of the Confederate Government to secure the return of escaped prisoners and to provide transportation to their respective commands within the Confederacy. For this purpose he made arrangements at Windsor, Niagara, Toronto, and Montreal to forward such as might require assistance to Halifax, from which point they were to be sent to Bermuda. In regard to Clay and Thompson he said, "I have availed myself of every opportunity to co-operate with those gentlemen and I think that I have been able to render useful service."

They opened a correspondence with Horace Greeley at Niagara on the I2th of July, 1864, with p. 6 II. 
a view to securing safe conduct to Washington to lay their proposals before President Lincoln. After the failure of the negotiations Mr. Holcombe returned by sea, and off the coast of Nova Scotia the vessel was sighted and fired upon by a Federal cruiser. In the panic which followed Mr. Holcombe asked to be put ashore, as he was desirous of avoiding capture, on account of many valuable papers in his possession. The light boat in which he was going ashore, accompanied by the Confederate spy Mrs. Greenhow, capsized, and he was saved from death only by the sailors. Mrs. Greenhow was dragged down by a bag of gold which she was conveying to her daughter.

The "Peace Congress" which convened in Washington, of which ex-President Tyler was president, was called into existence by this resolution passed by the legislature of Virginia on the Igth of January, I86I : "Resolved, That on behalf of the Commonwealth of Virginia, an invitation is hereby extended to all such States, whether slave-holding or nonslaveholding, as are willing to unite with Virginia in an earnest effort to adjust the present unhappy controversies, in the spirit in which the Constitution was originally formed, and consistently with its principles, so as to afford to the people of the slaveholding States adequate guaranties for the securing of their rights, to appoint commissioners to meet on the 4th day of February next, in the city of Washington, similar commissioners appointed by Virginia, to consider, and if practicable, agree upon some suitable adjustment." Two of the commissioners on the part of Virginia were University of Virginia men-John W. Brockenbrough '25 and 
James A. Seddon '35, and the third, William C. Rives, a Visitor from $1828-9$ and $1834-49$.

In the convention which met in Richmond on the I $3^{\text {th }}$ of February, I86r, and on the I7th day of April passed the ordinance of secession, or, to use its formal title, "An ordinance to repeal the ratification of the Constitution of the United States of America, by the State of Virginia, and to resume all the rights and powers granted under said Constitution," thirty-eight members had been educated in this University-viz:

William M. Ambler '3I, John B. Baldwin '36, Alfred M. Barbour '47, James Barbour '4I, Angus R. Blakey '34, George Blow '3I, George William Brent '4I, John A. Campbell '44, Allen T. Caperton '28, John Armistead Carter '26, Manilius Chapman '27, Samuel A. Coffman '44, John Critcher '35, Muscoe R. H. Garnett '38, Algernon S. Gray '29, Fendall Gregory '44, Addison Hall '47, Lewis E. Harvie '26, James P. Holcombe ' 36 , Marmaduke Johnson ' 47 , John J. Kindred '47, Walter D. Leake '33, John L. Marye '40, Edmund T. Morris '37, William J. Neblett 36, Hugh M. Nelson '30, William B. Preston '25, George W. Randolph '37, Robert E. Scott '25, William C. Scott '25, Charles H. Slaughter ' 36 , Samuel G. Staples '30, Chapman J. Stuart '36, Alex. H. H. Stuart '27, John T. Thornton '43, Robert H. Whitfield '38, Williams C. Wickham '37, Benjamin F. Wysor ' 34 .

Of these, Manilius Chapman, William C. Scott, and Chapman J. Stuart refused to sign the ordinance of secession. Scott, however, promptly responded to the first call of Virginia to arms, was made colonel, and commanded one of the first Virginia regiments sent into West Virginia early in the summer of $\mathrm{r} 86 \mathrm{r}$, and was at Laurel Hill, Rich Mountain, and Carrick's Ford. He survived the surrender only a few days.

Four of the six commissioners appointed in April, I86r, to arrange a temporary agreement between 
the Commonwealth of Virginia and the Confederate States for the purposes of meeting pressing exigencies affecting the mutual rights, interests and safety of Virginia and the Confederacy, were alumniJames C. Bruce '27, Lewis E. Harvie, James P. Holcombe, and William Ballard Preston.

The convention which passed the ordinance of secession appointed a commission to andit all claims for expenditures arising from the organization, equipment, and support of the land and naval forces called out for the defense of the Commonwealth. One of the three commissioners was John Randolph Tucker '39, Attorney-General of Virginia.

II

HoNORS IN THE JEFFERSON LitERARY SOCIE'TY

(See p. 243.)

The following list of the final presidents of the Jefferson Society is complete:

I826-Chapman Johnson, Va. I845-Roscoe B. Heath, Va. 1827-S. A. Townes, S. C. I846-Robert J. Morrison, Va. I828-R. H. Brown, Va. I847-V. E. Shepard, Va. 1829-Robert Toombs, Ga. T848-W. B. Woolridge, Va. I830-Wm. B. Napleton, N. J.' 1849-John A. Broadus, Va. 183I-Benj. F. Randolph, Va. I850-Richard H. Baker, Va. I832-Fairfax Catlett, Va. I85I-J. D. Pennybacker, Va. 1833-William D. Hodges, Va. I852-George L. Gordon, Va. I834-E. Taliaferro, Va. 1835-G. W. Trueheart, Va. I836-M. Carleton, Ala. I837-W. G. Gray, Md. I838-R. L. T. Beale, Va. I839-J. A. Strother, Ala. 1840-J. H. Oliver, La. I853-James William Morgan, Va.

I854-William R. Aylett, Va. I855-Jas. Taylor Jones, Ala. 1856-Creswell Garlington,S.C. I857-Edward C. Preston, La. I858-William G. Field, Va. 184I-Robert L. Dabney, Va. 1859-W. M. Dwight, S. C. I842-Edmund Randolph, Va. 1860-P. J. Glover, Ala. I843-J. F. Kunkel, Md. I844-Tiberius G. Jones, Va. 
I867-W. W. Foote, Tenn. 1868-J. B. Gantt, Ga. 1869-Shepard Barclay, Mo. 1870-S. P. Dendy, S. C. $1871-$ G. C. Hume, Md. 1872-Moses L. Wicks, Tenn. I873-B. C. Wicks, Md. 1874-Frederick F. Reese, Md 1875-Benj. Fitzpatrick, Ala. 1876-H. H. Downing, Va. I877-J. Allen Southall, Va. I878-L. W. Gunther, Md. 1879 -George D. Fawsett, Md. I880-Pembroke L. Thom, Md.I899-Joseph C. Taylor, Va. 1881-Floyd Hughes, Va. 1882-W. C. Eustis, D. C. I90I-J. Lindsey Heard, Va 1883-J. Hunter Pendleton, Va. I902-James Hay, Jr., Va. 1884-J. R. Anderson, Ga. I903-C. R. Williams, Va. I885-R. C. Taylor, Md. I904-J. A. W
rg05-J. A. Shiskmanian, Ky.
I886-Francis R. Lassiter, Va. I887-G. Wayne Anderson, Ga. I888-W. J. H. Bohannon, Va. I889-G. Gordon Battle, N. C. 1890-Raleigh C. Minor, Va. I89I-R. Spratt Cockrell, Fla. r892-J. Gordon Leake, Va. r893-Murray M. McGuire, Va. I894-Joseph A. Massey, Va. I895-Hollins N. Randolph, Va. I896-George Nelms Wise, Va. I897-Walter T. Oliver, Va. I900-W.T.Shannonhouse,N.C. IgOI-J. Lindsey Heard, Va. I903-C. R. Williams, Va.
rg04-J. A. Williams, Va.

This is a list of the readers as far as it can be constructed now :

1847-S. B. Paul, Va.

Edward Warren, N. C. I849-George L. Gordon, Va. John T. Points, Va.

I85I-William R. Aylett, Va. Charles T. Friend, Va. B. O. Holman, Ala. 1869-S. P. Luck, Va.
1854-D. B. DeSaussure, S. C. John L. Sehon, Ky.

1856-Robert Wilson, S. C. C. T. Goolrick, Va. r857-James C. Turner, Ala. I858-A. Q. Holladay, Va. 1860-Robert Falligant, Ga.

The following list of anniversary, or intermediate, orators is as nearly complete as can be made at this time :

1831-Charles Minor, Va. 1832-Thomas Semmes, Va. I834-Robert J. Davis, Va. O. N. Ogden, La. 1836-W. W. Boyce, S. C. Joseph D. Shields, Miss. I838-R. B. Gooch, Va. 1839-Joseph D. Shields, Miss. I840-Thomas B. Bird, S. C.
I84I-W. M. Cook, Va. J. H. Parkhill, Fla. r842-John C. Rutherford, Va. I846-J. S. Meredith, Va. I847-L. J. Bell, Va. 1848-Marmaduke Johnson, Va. I849-John Lyon, Va. James A. Latane, Va. I850-J. Peyton Clark, Va. 
I85I-J. Preston White, Va. I852-J. W. Hutcheson, Va. I853-J. B. Collins, Mo.

W. M. Fishback, Va. I855-O. Shepperson, Va.
I857-K. Kemper, Va. 1859-J. P. Sheffey, Va. I860-W. R. Berkeley, Va. I867-Thomas H. Burke, Va. I868-W. T. Burdett, Va. I869-C. F. McKesson, N. C.

These are the final orators, as far as can be learned now :

I837-Thomas L. Walker, Ala. I838-B. Johnson Barbour, Va. I839-Alex. Walker, Va. I840-J. H. Parkhill, Fla. I844-J. T. Thornton, Va. I845-P. H. Aylett, Va.

V. E. Shepherd, Va.

H. St. G. Tucker, Va. 1847-John A. Broadus, Va. I849-F. W. M. Holliday, Va. I858-John Johnson, S. C.

Robert G. H. Kean, Va. 1850-George L. Pollard, Va. I85I-W. T. H. Baylor, Va. J. Stuart Brown, Va. I852-Daniel B. Lucas, W. Va. 1854-W. W. Gordon, Va. I856-Albert Richie, Md. 1857-Daniel Cosby, Jr., Va. Joseph H. Hodgson, Va. ( $1859-6 \mathrm{I}-$ No record.)

The debater's medal was established during the session of $1856-57$, and there is record of the awards mentioned below. Beginning with the year 1867 the honor men are mentioned in conjunction:

1858-Charles S. Stringfellow, Va.

I859-None recorded.

I860-James M. Boyd, Va. [The war suspended the Society during I86r-65.]

r867-Alex. P. Humphrey, Ky., debater; Thomas H. Burke, Va., orator.

I868-Ernest W. Duncan, W. Va., debater; William T. Burdett, W. Va., orator.

I869-W. W. Adams, Va., debater; T. T. Singleton, Miss., orator.

I870-No record.

I87I-H. H. Martin, Va., debater; G. E. Nelson, Va., orator. I872-Henry T. Kent, Va., debater; L. M. Elder, Tenn., orator.

1873-J. S. Williams, Tenn., debater; W. R. Alexander, Va., orator; T. W. Strange, N. C., declaimer.

I874-J. E. Powell, Mo., debater; M. W. Ransom, Jr., N. C., orator (vice Roger Johnson, resigned).

[This year efforts were made in the Jefferson as well 
as the Washington to abolish the medal system, it being alleged that to it was due the violent partisan spirit which often prevailed in the societies.]

1875-Leo N. Levi, Texas, debater; A. M. Robinson, Texas, orator (vice Lyon G. Tyler, Va., resigned).

1876-Bernard Peyton, Va., debater; A. P. Thom, Va., orator (vice Lyon G. Tyler, Va., resigned).

1877-A. G. Stuart, Va., debater; C. A. Culberson, Texas, orator.

1878-Dudley G. Wooten, Texas, debater; F. T. Glasgow, Va., orator.

1879-P. A. Bruce, Va., debater; Wyndham R. Meredith, Va., orator.

I880-William Cabell Bruce, Va., debater; Thomas Woodrow Wilson, N. C., orator.

I88I-W. S. Lefevre, Md., debater; Robert W. Mallet, Va., orator.

I882-Charles W. Kent, Va., debater; William P. Trent, orator.

I883-M. C. Pope, debater; no orator's medal awarded. [Mr. Pope was called from the University before the commencement, leaving the society without a speaker for its celebration. William P. Trent and Robert W. Mallet filled the vacant places on the program.]

I884-F. W. Gregory, Miss., debater; John B. Henneman, S. C., orator.

I885-W." B. Richards, Va., debater; F. R. Lassiter, Va., orator.

I886-G. W. Anderson, Ga., debater; C. A. Swanson, Va., orator.

I887-U. W. Muir, Ky., debater; M. S. Macon, La., orator.

I888-J. L. Kelley, Va., debater; J. G. Scott, Va., orator.

1889-Charles P. Fenner, La., debater; W. S. Hamilton, Ga., orator.

I890-P. H. C. Cabell, Jr., debater; E. L. Boyle, Tenn., orator.

I89I-William G. Peterkin, W. Va., debater; Henry Lewis Smith, N. C., orator.

I892-No award of debater's medal; L. H. Machen, Va., orator.

I893-Lewis H. Machen, Va., debater; Benjamin Franklin Martin, Va., orator.

1894-No award of debater's medal; Hugh M. Dorsey, Ga., orator.

I895-No award of debater's medal; W. K. Allyn, Va., orator.

1896-Henry A. Hopkins, Texas, debater; W. S. Hancock, Va., orator. 
I897-Albert Fink, Ark., and Walter T. Oliver, Va., debaters; Henry A. Hopkins, Texas, orator.

I8g8-H. W. Mayo, Va., debater; Joseph C. Taylor, Va., orator.

1899-E. Reinhold Rogers, Va., debater; George P. Bagby, Va., orator.

I900-S. E. Bradshaw, Ky., debater; Wm. C. Munroe, Fla., orator.

Ig0I-J. Littleton Jones, Ga., debater; T. D. Savage, N. C., orator.

1902-Wythe L. Kinsolving, Va., orator.

1903-John D. McInnis, Miss., orator.

I904-Roger B. Wood, debater; Joseph S. Lawton, Ky., orator.

1905-John A. Shishmanian, Ky., orator.

\section{III}

HoNORS IN THE WASHINGTON LITERARY SOcIETy

(See p. 249.)

The final presidents from the beginning to the present, as far as can be ascertained, have been:

1844-J. F. Wooten, N. C. I870-J. C. McKennie, Va. 1845-Presley C. Lane, Ala. I871-Barnett Gibbs, Texas. I846-George A. Hall, Ga. 1872-Walter G. Charlton, Ga. I847-William H. F. Hall, Ga. I873-Richard H. Maury, Miss. I848-J. F. Marshall, Miss. I874-Thomas L. Raymond, La. 1849-John L. Cochran, Va. 1875-Benjamin Johnson, Va. I850-Frederick Floyd, Va. I876-Fred. E. Conway, Ark. 185I-Frank V. Winston, Va. 1877-Frank P. Farish, Va. I852-J. F. Deloney, Ala. I878-V. M. Potter, Ky. I853-Edward S. Joynes, Va. I879-None recorded. I854-George B. Talyor, Va. I880-John F. B. Beckwith, Ga. I855-Virginius Dabney, Miss. I881-S. J. Shepherd, Tenn. 1856-John M. Bolling, Va. I882-W. D. Toy, Va. I857-Algernon S. Epes, Va. I883-W. T. Turnbull, Fla. I858-Thomas U. Dudley, Va. I884-J. I. Van Meter, Ohio. I859-Edward L. Martin, Del. 1885-C. H. Fauntleroy, Va. I860-C. W. Wilson, Va. I886-Lewis M. G. Baker, Va. I86I-I865-Suspended during I887-W. E. Allen, Va. the war. I888-S. L. Kelley, Va. I866-Micajah Woods, Va. I889-F. M. Simonton, Fla. 1867-C. J. Faulkner, W. Va. 1890-Charles F. Coleman, Fla. I868-W. O. Harris, W. Va. I89I-George N. Conrad, Va. I869-S. T. Phillips, Va. I892-Robert F. Leach, Md. 
1893-Allen P. Gilmour, Ky. I899-Patrick H. Aylett, Va. 1894-J. Bernard Handlan, Va.Igo0-E. H. Fulton, Va. I895-Joseph T. Allyn, Va. Ig0I-J. D. Hauk, Va. I896-Alex. Scott Bullitt, Ky. I902-W. C. Latimer, S. C. I897-Frank Grey Newbill, Va.I903-R. H. Latham, Va. I898-Charles N. Joyce, Md. I904-John S. Flory, Va. ig05-T. M. Wampler, Va.

The readers from 1838 , until the intermediate celebration was eliminated from college exercises, were :

1838-Robert B. Ridley, N. C. I854-R. M. Mallory, Va. 1846-Thomas J. Sharp, Miss. 1855-Theo. W. Brevard, Fla. 1847-W. A. Quarles, Ky. $1856-\mathrm{S}$. Wellford Corbin, Va. I848-William H. F. Hall, Ga. I857-Thomas U. Dudley, Va. I849-Daniel Lyon, Jr., Va. I858-T. G. Wertenbaker, Va. 1850-Frank V. Winston, Va. 1859-J. William Jones, Va. I85I-R. S. Henson, Va. I860-Arthur J. Arnold, Va. 1852-A. B. Evans, Va. I86I-William H. Henson, Va. 1853-H. A. Carrington, Va. 1866-Edmund C. Minor, Va. I869-J. G. Rogers, Md.

In the list of "intermediate orators" about the same gap occurs as in the readers-from 1839 to I846 inclusive. Thereafter no break appears until I86I-65:

1836-James T. Sharp, Va. I854-George B. Taylor, Va. 1837-Alexander Walker, Va. I855-A. E. Dickinson, Va. 1838-Robt. S. Hamilton, Va. 1856-Thomas T. Jones, Va. 1839-J. B. Bird, S. C. I857-Erasmus K. Harris, Va. 1847-Thomas Sharp, Miss. I858-Littleton J. Haley, Va. 1848-John Griffin, Miss. I859-T. W. Mason, Va. I849-John Hart, Va. I860-S. Taylor Martin, Va. I850-Fernando R. Farrar, Va.I86I-Alex. W. Weddell, Va. I85I-Alex. N. Jordan, Va. I866-William T. R. Bell, Va. I852-P. S. Henson, Va. 1853-Wm. D. Thomas, Va. I869-Rich. S. Jeffcries, Va.

The valedictorians: 1839-J. P. Holcombe, Va. I847-Robert C. Saffold, Miss. I840-Thomas Slaughter, Va. I848-Smith C. Daniell, Va. I846-Thomas Sharp, Miss. I849-Wm. Pope Dabney, Va. 
I850-Thomas W. Haynes, Va.1853-H. A. Carrington, Va. I85I-Samuel Garland, Va. $1854-\mathrm{H}$. Embry Merritt, Va. I852-W. B. Newton, Va. I855-Wilson S. Newman, Va. I856-Given Campbell, Ky.

During the session of $1856-57$ the Washington Society instituted a debater's medal and after the war the orator's medal. In the following list the debaters are all medalists and the orators medalists after I869:

1857-Given Campbell, Ky., debater; Robert Davis, Va., orator.

1858-Alexander B. Cochran, Va., debater; Llewellyn Southgate, Va., orator.

I859-Douglas F. Forest, Va., orator.

I860-William Allen, Va., debater; William Frederick Ogden, La, orator.

I86I-Celebration abandoned, and no medal awarded; J. W. Harris had been appointed orator before the decision to suspend.

I866-John S. Wise, Va., debater; J. N. Dunlop, Va., orator. 1867-David S. Pierce, Va., debater; Charles E. Sears, Va., orator.

I868-S. M. Wynne, Ga., debater; S. McKinney, Tenn., orator. 1869 -No record.

I870-Linden Kent, Va., debater.

I87I-E. H. Farrar, La., debater; G. E. Penn, Va., orator.

1872-H. A. Collum, La., debater; C. A. Jenkins, Miss., orator. 1873-F. R. Graham, La., debater; J. N. Stephenson, Va., orator.

I874-John S. Brooks, Va., debater; R. S. Saulsbury, Ga., orator.

I875-C. E. Nicol, Md., debater; H. C. Stuart, Va., orator.

I876-T. E. Blakey, Va., debater; J. G. Colley, Ga., orator.

I877-J. F. Ellison, Va., debater; Junius Rochester, Ky., orator.

1878-Richard A. Jackson, Md., debater; Benjamin F. Long, N. C., orator.

I879-Not organized this year.

I880-No award.

I88I-W. W. Wilkinson, Ala., debater; F. M. O. Fenn, Texas, orator.

I882-H. P. Lawther, Texas, debater; H. G. Peters, Va., orator. 
I883-W. B. Eldridge, Tenn., debater; W. G. Winstock, Va., orator.

1884-L. H. Pugh, La., debater; B. H. Lee, Miss., orator.

I885-W. H. Bryant, Va., debater; W. J. Shelburne, Va., orator.

I886-R. G. Bickford, Va., debater; J. G. Covington, Ky.: orator.

I887-J. B. Gibson, Miss., debater; T. E. Ryals, Ga., orator.

I888-L. G. M. Baker, Va., debater; F. Causey, Va., orator.

I889-J. A. Barclay, Ky., debater; F. W. Weaver, Va., orator.

I890-R. M. Banks, Jr., Miss., debater; G. N. Conrad, Va., orator.

I89I-Charles F. Spencer, Ky., debater; Henry A. Etheridge, Ga., orator.

I892-Robert E. Cofer, Texas, debater; Harris L. Moss, Va., orator.

1893-John Henry Nininger, Va., debater; Algernon $B$. Chandler, Va., orator.

1894-Charles R. Frankum, Va., debater; Edward L. Greever, Va., orator.

I895-J. R. Rew, Va., debater; A. E. Strode, S. C., orator.

I896-G. W. Holland, Va., debater; Clyde W. Portlock, Tenn., orator.

I897-Preston W. Campbell, Va., debater; Charles N. Joyce, Md., orator.

I898-C. L. Kagey, Va., debater; D. S. Burleson, Va., orator. 1899-J. Douglass Mitchell, Va., debater; A. Leo Obendorfer, Va., orator.

1900-Arthur J. Morris, Va., debater; Roscoe C. Nelson, Va., orator.

Igor-E. B. Setzler, S. C., debater and orator.

I902-Thos. W. Halloman, Miss., inter-society debater; J. S. Barron, Va., debater.

1903-W. C. Latimer, S. C., inter-society debater; W. T. Anglin, Va., orator.

1904-H. M. Roberts, Ky., orator.

I905-Lee Bidgood, Va., inter-society debater; Samuel W. Edmondson, Va., orator.

In I896 Dr. James A. Harrison provided a trophy to be contested for by the Jefferson and Washington literary societies. It is a solid silver laurel wreath encircling a copper scroll for the names of the winning contestants. Thus far the record is: 
Washington Society. I896-C. W. Portlock. 1898-E. B. Setzler. I90I-J. P. McConnell. 1903-W. M. James. John C. Myers. 1905-J. W. Wayland. J. I. Viney.

\author{
Jefferson Society. \\ I897-Walter T. Oliver. \\ Albert Fink. \\ 1902-Irvin W. Ayres. \\ F. W. Gwathmey. \\ 1904-Roger B. Wood. \\ J. A. Williams.
}

\section{Magazine MEDALISTS}

(See p. 258.)

I858-John Johnson, Charleston, S. C., subject, "Drudgery and Leisure."

I859-James McDowell Graham, Lexington, Va., "The Worship of Nature."

I860-Leigh Robinson, Washington, D. C., "What Will He Do With It?"

I868-A. M. Miller, Petersburg, Va., "The Bacchal of Euripides."

1870-Charles Wickliffe Yulee, Fernandina, Fla., "Michael Angelo."

1872-Thomas A. Seddon, Fredericksburg, Va., "The Ballad of the Ancient Mariner."

I873-R. T. W. Duke, Jr., Charlottesville, Va., "Old Letters." I874-William W. Thum, Louisville, Ky., "The Death of Marlowe."

1875-Marcus B. Almond, Charlottesville, Va., "Glendower." 1876-Leo N. Levi, Galveston, Texas, "Charles II and His Times."

I877-William P. Kent, Virginia, "The Moral Significance of the American Centennial." "

1878-Dudley G. Wooten, Texas, "Uncrowned Heroes."

1879-Walter S. Lefevre, Maryland, "Queen Mab: A Study in Shelley."

I880-William Cabell Bruce, Virginia, "John Randolph." I88I-Samuel H. James, Louisiana, "Diogenes Teufelsdrockh." I883-James Gazaway Ryals, Georgia, "Tennyson and The Idyls of the King."

1885-Blewitt H. Lee, Mississippi, "Shakespeare's Songs." 1886-John Singleton Mosby, Virginia, "The Story of the Nile."

I887-Frank E. Corbett, Texas, "Napoleon III." 
I888-Ernest M. Stires, Virginia, "The Eastern Question."

1889-Thomas Longstreet Wood, Virginia, "Life in Shiflet's Hollow."

1890-H. Snowden Marshall, Maryland, "A Crusade by Turks."

1891-Stuart-Menteth Beard, Louisiana, "Essex and Bacon."

1892-Charles Trotter Lassiter, Virginia, "The Parliament of Man."

I893-Charles Hall Davis, Virginia, "The Chief of Women Poets."

I894-J. Spottiswood Taylor, Virginia, "An Unenterprising Fellow."

1895-John Handy Hall, Virginia, "Marah."

1896-Schuyler Poitevent, Mississippi, "The Strange Music of Biloxi Bay." Story.

J. Pierce Bruns, Louisiana, Translation medal.

I897-Morris P. Tilley, Virginia, "Coffee Houses and Coffee Drinkers." Essay.

Mayer L. Halff, Texas, Translation medal.

J. Pierce Bruns, Louisiana, Original Verse medal.

1898-E. L. Grace, Virginia, "Sidney Lanier." Essay.

L. P. Chamberlayne, Virginia, Translation medal.

J. W. Rice, Texas, Original Verse medal.

J. W. Rice, Texas, "A Sketcher of Skulls." Story.

1899-Carol M. Newman, Virginia, "Some Charms of Kipling." Essay.

Philip F. DuPont, Delaware, Original Verse medal.

Morris P. Tilley, Virginia, "The Body-Snatching of Mr. Peppers." Story.

190I-Carol M. Newman, Virginia, "P. R. R. 1313." Story.

1902-John W. Wayland, Virginia, "Two Elements of a Literary Atmosphere, and Virginia's Title to Them." Essay.

1902-Robert B. Tunstall, Virginia, "A Victim of Chivalry." Story.

Leonidas R. Whipple, Missouri, "Is the Literary Centre of the United States Moving Westward?" Essay.

1903-W. McC. James, Maryland, "A Strange Case." Story.

E. N. Calisch, Virginia, "The Settlement at Jamestown." Essay.

1904-W. McC. James, Maryland, "The Syndicate of Crime." Story.

1905-James C. Bardin, Virginia, "The Last Crime." Story.

A. Frederick Wilson, New Jersey, "Poetry and the Present Day." Essay. 
The original verse medal was won by Lewis $P$. Chamberlayne of Virginia in 1902, H. R. Denton of New York in 1903, by John W. Wayland of Virginia in 1904, and by A. Frederick Wilson of New Jersey in 1905 .

The Colonial Dames of Virginia give a prize in money each year for the best essay appearing in the magazine on some subject related to colonial Virginia history. These have been won by John W. Wayland in I9OI, C. C. Wright in I9O2, John I. Viney in 1903 , Robert H. Webb in 1904, and by John W. Wayland in 1905. All of the winners of this prize have thus far been Virginians.

Mr. William Jennings Bryan has established a prize for the best essay in the magazine on the theory of government. The winners thus far have been John W. Wayland (successful twice), and R. H. Latham of Virginia.

\section{V \\ RELIGIOUS LEADERS}

(See p. 317.)

Chaplains to the University for the sessions named:

1829-30-Smith, Presbyterian.

I830-32-No chaplain.

I832-34-William Hammett, Methodist.

1834-35-N. H. Cobbs, Episcopalian.

I835-36-Robert Ryland, Baptist.

1836-37-S. Tustin, Presbyterian.

1837-38-J. P. B. Wilmer, Episcopalian.

I838-39-D. S. Doggett, Methodist.

I839-40-James B. Taylor, Baptist.

I840-4I-Wm. S. White, Presbyterian.

184I-42-W. M. Jackson, Episcopalian. 
1842-43-Leonidas Rosser, Methodist.

1843-44-E. G. Robinson, Baptist.

I844-45-Wm. S. White, Presbyterian.

1845-46-W. D. Jackson, Episcopalian.

I846-47-Jacob Manning and D. Wood, Methodist.

1847-49-J. R. Scott, Baptist.

I849-5I-Wm. H. Ruffner, Presbyterian.

185I-52-W. W. Bennett and B. Gibson, Methodist.

1852-53-B. Gibson, Methodist.

1853-55-Wm. D. Hanson, Episcopalian.

1855-57-John A. Broadus, Baptist.

1857-59-Dabney C. Harrison, Presbyterian.

I859-6I-J. C. Granbery, Methodist.

I86I-65-No chaplain. J. C. Granbery for the term of I86I-63, Methodist, and J. C. McCabe I863-65, but neither officiated.

I865-67-J. S. Lindsay, Methodist.

1867-69-Peter Tinsley, Episcopalian.

1869-7 I-George B. Taylor, Baptist.

1871-73-T. D. Witherspoon, Presbyterian.

1873-75-S. A. Steele, Methodist.

1875-77-Robert J. McBride, Episcopalian.

1877-79-A. B. Woodfin, Baptist.

I879-8I-Clement R. Vaughan, Presbyterian.

I881-83-J. T. Whitley, Methodist.

I883-85-Otis R. Glazebrooke, Episcopalian.

I885-87-George B. Taylor, Baptist.

1887-89-James M. Rawlings, Presbyterian.

I889-9I-Collins Denny, Methodist.

I89I-93-James L. Lancaster, Episcopalian.

I893-95-J. Wm. Jones, Baptist.

1895-96-A. R. Cocke, Presbyterian.

I896-97-L. C. Vass [died before entering on his service].

Presidents of the Y. M. C. A. for the sessions ending in the years named:

I859-John Johnson, Episcopalian; Thomas Hume, Baptist.

1860-Isaac Heiskell, Presbyterian; George Vaughan, Methodist.

I86I-James M. Garnett, Episcopalian; Powell Grady, Baptist.

I86I-65-Period of the civil war.

I866-A. Frederick Fleet, Baptist; Robert Stiles, Presbyterian.

I867-James Drake, Methodist; F. H. Burke, Episcopalian. 
1868-Charles Taylor, Baptist; Whitefield Erving, Presbyterian.

1869-P. H. Baskerville, Episcopalian.

1870-W. R. Barksdale, Baptist; W. R. Atkinson, Presbyterian.

I87I-J. W. C. Davis, Methodst; A. S. Johns, Episcopalian.

1872-James P. Harrison, Baptist; F. P. Huntington, Presbyterian.

1873-F. Marvin, Methodist; C. H. Cocke, Episcopalian.

1874-Nelson Waller, Baptist; W. M. Rogers, Presbyterian.

I875-E.dward Saunders, Episcopalian; W. D. Toy, Baptist.

1876-William McK. Murrell, Methodist; Charles W. Dabney, Presbyterian.

I877-Henry Harris, Baptist; E. L. Goodwin, Episcopalian. 1878-W. B. Taylor, Baptist; J. C. Lamb, Episcopalian.

1879-J. C. Lamb, Episcopalian; J. G. Shackelford, Ëpiscopalian.

1880-Samuel B. Woods, Presbyterian, [both terms].

I88I-R. A. Robinson, Presbyterian; Walter D. Toy, Baptist. I882-W. J. Bingham, Presbyterian; G. H. Smith, Methodist. 1883-James G. Ryals, Baptist; W. J. Bingham, Presbyterian. I884-C. H. Fauntleroy, Episcopalian; C. M. Bradbury, Methodist.

I885-W. C. Whitescarver, Baptist; C. C. Cox, Baptist.

I886-C. W. Sams, Episcopalian; J. A. Ingle, Episcopalian.

1887-J. S. Davis, Episcopalian; H. L. Smith, Presbyterian.

I888-C. M. Bradbury, Methodist; R. K. Masse, Episcopalian. terian.

1889-W. H. Venable, Episcopalian; J. B. Woods, PresbyI89o-J. B. Minor, Jr., Episcopalian; J. K. Peebles, Presbyterian.

I89I-J. G. Scott, Episcopalian [both terms].

I892-William G. Peterkin, Episcopalian; John Nicolson, Jr., Presbyterian.

I893-J. I. Curtis, Presbyterian [both terms].

I894-I. C. Harrison, Baptist.

I895-E. L. Woodward, Episcopalian.

I896-H. O. Murfee, Baptist.

I897-E. L. Woodward, Episcopalian.

I898-Charles Hancock, Presbyterian.

1899-J. P. McCallie, Presbyterian.

1900-E. Reinhold Rogers, Episcopalian.

IgOI-Roger A. Walke, Episcopalian.

1902-E. P. Dandridge 2d, Episcopalian.

1903-E. P. Dandridge 2d, Episcopalian.

I904-A. S. Taylor, Baptist.

rgo5-A. S. Taylor, Baptist.

1906-A. S. Johnstone, Presbyterian. 


\section{VI}

\section{Geineral Alumni Association}

(See p. 323.)

The following is a list of the presidents and orators of the General Alumni Association for many of the years of its existence. Unfortunately the record is deficient:

I867-Marmaduke Johnson of Virginia, orator; J. P. Holcombe of Virginia, president.

I868-Charles Marshall of Maryland, orator; J. P. Holcombe of Virginia, president.

I869-William C. Rives of Massachusetts, orator; A. H. H. Stuart of Virginia, president.

I870-J. W. Stevenson of Kentucky, orator; A. H. H. Stuart of Virginia, president.

I87I-W. B. Napton of Missouri, orator; J. L. Marye of Virginia, president.

I872-W. B. Quarles of Tennessee, orator; J. L. Marye of Virginia, president.

I873-Thomas Swann of Maryland, orator; B. J. Barbour of Virginia, president.

I874-J. H. Kennard of Louisiana, orator; B. J. Barbour, of Virginia, president.

I875-R. M. T. Hunter of Virginia, orator; D. B. Lucas (poem), of West Virginia; B. J. Barbour of Virginia, president.

I876-F. W. M. Holliday of Virginia, orator; B. J. Barbour of Virginia, president.

1877-No orator; J. M. Hanger of Virginia, president.

I878-J. C. Southall of Virginia (opening of Brooks Museum), orator; J. M. Hanger of Virginia, president.

I879-T. U. Dudley of Kentucky, orator; J. R. Tucker of Virginia, president.

I880-J. H. Chamberlayne of Virginia, orator; J. R. Tucker of Virginia, president.

I88I-J. O. Broadhead of Missouri, orator; J. W. Stevenson of Kentucky, president.

I882-H. Tutwiler of Alabama, orator; J. W. Stevenson of Kentucky, president.

I883-W. C. Rives of Massachusetts (W. B. Rogers Memorial), orator; F. R. Rives of New York, president. 
I884-A. P. Humphrey of Kentucky, orator; F. R. Rives of New York, president.

I885-C. E. Stuart of Virginia, orator; C. M. Blackford of Virginia, president.

1886-C. E. Fenner of Louisiana, orator; C. M. Blackford, of Virginia, president.

I887-H. A. Herbert of Alabama, orator; H. E. Jackson of Tennessee, president.

I888-W. Gordon McCabe of Virginia, orator; H. E. Jackson of Tennessee, president.

I889-H. T. Kent of Missouri, orator; A. E. Richards of Virginia, president.

I890-J. L. Gordon of Virginia, orator; A. E. Richards of Virginia, president.

I89I-W. L. Wilson of West Virginia, orator; Charles Marshall of Maryland, president.

I892-L. S. Marye of Virginia, orator; Charles Marshall of Maryland, president.

I893-W. C. Bruce of Maryland, orator; Joseph Bryan of Virginia, president.

I894-Rev. John Johnson, D. D., of South Carolina, orator; Joseph Bryan of Virginia, president.

I895-Woodrow Wilson of New Jersey, orator; George Perkins of Virginia, president.

I896-Rev. J. S. Lindsay, D. D., of Massachusetts, orator; George Perkins of Virginia, president.

I897-W. R. Abbot of Virginia, orator; Kev. Randolph $\mathrm{H}$. McKim, D. D., of Washington, D. C., president.

I898-Rev. Randolph H. McKim, D. D., of Washington, D. C., orator; George Perkins of Virginia, president.

I899-John Bassett Moore of New York, orator; George Perkins of Virginia, president.

I900-Leigh Robinson of Washington, D. C., orator; Samuel Spencer of New York, president.

I90I-Blewett Lee of Illinois, orator; Thomas Nelson Page of Washington, D. C., president.

I902-E. H. Farrar of Louisiana, orator; Joseph B. Dunn of Virginia, president.

I903-W. Gordon Robertson of Virginia, orator; James B. Sener of Washington, D. C., president.

I904-Henry Louis Smith of North Carolina, orator; George W. Morris of Virginia, president pro tem.

1905-Charles Forest Moore of New York, orator; Thomas Nelson Page of Washington, D. C., president. 


\section{VII}

\section{Chairmen of the Faculty}

(See p. 347.)

The following table exhibits the chronological order of the chairmen of the faculty. The Roman figures indicate the personal or individual succession, while the Arabic numerals mark the order of official terms :

I. I. George Tucker, 1825-6.

II. 2. Robley Dunglison, I826-7.

III. 3. John Tayloe Lomax, 1827-8.

4. George Tucker, 1828-9.

5. Robley Dunglison, I829-30.

IV. 6. Robert M. Patterson, I830-2.

7. George Tucker, I832-3.

V. 8. Charles Bonnycastle, I833-5.

VI. 9. John A. G. Davis, I835-7.

VII. Io. Gessner Harrison, 1837-9.

II. John A. G. Davis, I839-40.

12. Gessner Harrison, 1840-2.

VIII. I3. H. St. George Tucker, 1842-4.

IX. 14. William B. Rogers, I844-5.

X. I5: Edward H. Courtenay, I845-6.

XI. I6. James L. Cabell, I846-7.

I7. Gessner Harrison, 1847-54.

XII. I8. Socrates Maupin, 1854-70.

XIII. 19. Charles S. Venable, I870-3.

XIV. 20. James F. Harrison, I873-86.

21. Charles S. Venable, I886-8.

[William M. Thornton, vice-chairman.]

XV. 22. William M. Thornton, I888-96.

XVI. 23. Paul B. Barringer, I896-1903.

XVII. 24. James M. Page, I903-4 [September I5]. 



\section{INDEX}

Academic department, 332.

Academics' Literary Society, 237, 245.

Albemarle Academy, 17; board of trustees organized, 18; Jefferson a trustee, I9; lottery to create a fund, 19; petition to the legislature, 22.

Alumni association, 321; chartered, 323; orators and presidents, 373.

Alumni Bulletin, 260.

Annals of Mathematics, 260.

Annex, 189; destroyed by fire, 279.

Architect and architecture, 181.

Athletic Association, General, 304.

Athletics, 294; official countenance of, 294; regime of D'Alfonce, 295; cricket, 296; early years of baseball, 297; boating, 299; races and records, 299; Squibb Gymnasium, 298, 301; field sports, 302; football, 304.

Blaettermann, George, engaged as professor, 86; his scholarship, 96 .

Bledsoe, Alfred Taylor, 335.

Boeck, Leopold J., 343 and note.

Bonnycastle, Charles, engaged as professor of natural philosophy, 88; death, 99.

Bowditch, Nathaniel, declines chair, 74.

Brooks Museum, 192.

Buildings, 37, 40, 62, 189; plans for, 37, 177; proctor's report of progress, 179.

Cabell, Joseph Carrington, 23; Jefferson's prevision of his usefulness, 25; enters the legislature, 26; relations to the petition of Albemarle Academy, 26, 27; discusses the personnel of the
House, 46; engrafts on a popular school bill a provision for a university, 42; declines to serve as a member of the Rockfish commission, 48; management of the University bill in the legislature, 50; his health, 52, 54, 58; wishes to retire from the Senate, 58 ; procures many appropriations, 56 advocates putting all the money in buildings, 56; frustrates the scheme for the removal of William and Mary, 64.

Caracchi's bust of Jefferson, 267 .

Carr, Peter, trustee of Albemarle Academy, 19; receives an important paper from Jefferson, 22.

Carr's Hill, 195.

Central College authorized by law, 27; corner-stone laid, 38; Lexington and Staunton antagonistic, 45; other troubles, 31; first board of visitors, 34, et seq.; becomes the University of Virginia, 55.

Chairmen of the Faculty, 348; list of, 375 .

Chaplain system, 316; abandoned, 317; general secretaryship substituted, 317 .

Chaplains, list of, 370; in pavilions, 290.

Civil war, 199; student sentiment, 199, 203, 250; martial fever among the professors, 204; first Confederate flag, 200; battalion drill on the lawn, 207; students go to the front, 209; professors remain at their posts, 213; their services, 213-14; Sheridan's raid, 214; alumni in the military service, 354 ; in the civil service, 355; members of the Secession convention, etc., 359 . 
College Topics, 259.

Collegian, 254.

Commencement, the first public, 243 .

Confederacy-See Civil war.

Confederate memorial tablets, 221.

Cooper, Thomas, 2I; elected professor, 68; Virginian sentiment antagonistic to him, 69; Jefferson defends his appointment, 70.

Corks and Curls, 260.

"Court of the University," 136; legislature declines to establish, I 40, 141 .

Cricket, 296.

D'Alfonce, J. E., 295.

Davis, John A. G., his "Exposition" defending the reinstatement of the students expelled in 1836 , 152; assassinated, 155; Dr. Dabney's account of his murder, 156 ; Simms suspected and arrested, I57; released on bail, 159 .

Dawson's Row, 195.

Degrees and honors, 326; requirements, 328 , et seq.

Dunglison, Robley, engaged as professor of medicine, 88; Jefferson's physician, ror ; death, roo.

"Dyke," 3ro; story of a dyking, 3 ro.

Easter at the Universtiy, 3 I3.

Emmet, John Patten, elected professor of chemistry, 77; characteristics, 102.

Engineering department, 343 .

Fayerweather Gymnasium, 286, 303 .

Field and track sports, with records, 302.

Financial, 37, 40, 42, 56, 60-62, 64, 193, $285,289-90$.

Fire of $1895,278-84$.

Fraternities (Greek letter), clubs, etc., 306.

Galt's statue of Jefferson, its removal from the library during the fire of 1895,280 .

Gilmer, Francis Walker, 77; elected professor of law, 108; his mission to Europe, 82, 83, 85-9; cordial reception, 86; disappointments in Scotland, 87 ; rough voyage homeward, 88; twice declines professorship of law, ro8; accepts, $8 \mathrm{r}$; death, rog.

Glover, John A., killed by a showman, 164 .

Government of the University, II 5 , et seq.; Jefferson's ideal of student self-government, I19, I 28; early rising "enactment," 123; janitorial tribulations, 124; uniform dress law, 125; "Court of the University," 136 .

Hammett, Rev. William, 145, and note 2.

Harrison, Gessner, successor of George Long, 333 .

Holcombe, James P., professor of law, 342; in Confederate Congress, 356; secret agent to Canada, 357; in Secession Convention, 359 .

Honor system, 166; spirit of honor triumphant, 174; professor Tucker's ordinance, 174 ; more involved than cheating at examination, 175 .

"Hot Feet," 307-10.

Jefferson, Thomas at Williamsburg, II, I4; his efforts for popular education, I2-13; relations to William and Mary College, 14-15; abandons William and Mary, 25; retires from public life, 17; prepares a code of regulations for Albemarle Academy, 21; his plans for University buildings, 177; proposes to convert the Central College into the State University, 39; member of the Rockfish Commission, 48; drafts a bill for the establishment of ten colleges, 65; assailed as an enemy of religion, $7 \mathrm{r}$; solves the problem of sectarian instruction, 72 ; essay on Anglo-Saxon, 97, and 
note 3 ; dissents from the Visitors as to the creation of a presidency, 112 ; responds to a toast, 275 .

Jefferson Literary Society, 234; its badges, 237; Jefferson declines honorary membership, 239; anniversary celebrations, 243; final presidents, 360; medalists and honor men, 36I-4; proposes monument to Confederate Soldiers, 220 (note).

Jefferson Monument Magazine, 248, 257.

Key, Thomas Hewitt, engaged as professor of mathematics, 86; his attachment to the sciences, 97; resignation, 98,335 .

Knox, Dr., appointed professor, 38.

Kraitsir, Charles, 334 and note.

Ladies' Confederate Memorial Association, 220.

Lafayette's visit to the University, 274; Jefferson's response to a toast, 275.

Law department, 342 .

Law professorship declined by Gilmer and others, rog; Wirt declines and suggests Lomax, II4.

Library, 262; Jefferson's catalogue, 262; his books, 267; gifts to, 269; destroyed by fire, 270 ; removal of Galt's statue of Jefferson, 280; portraits, statuary, cabinets, etc., 273 .

Literary Fund, proposition to give - it to the primary schools, 42; loans to the University, 56, 6o, 62.

Literary societies-Academics, 237; Jefferson, 234; Medical, 237; Parthenon, 248; Patrick Henry, 234; Philomathea, 248; University, 449; Washington, 245.

Lomax, John Tayloe, first professor of law, Ir4.

Long, George, engaged as professor of Latin, 87; married Mrs. Sel- don, 95; resigned and returned to England, 96; his scholarship, 96.

Madison Hall, 320.

Magazine-See University Literary Magazine.

Medalists-Bryan, 370; Colonial Dames, 37o; Jefferson Society, 362; Magazine, 368; Original verse, 370; Washington, 366 .

Medicine, department of, 339 .

Medical Literary Society, 237.

Military companies, 198; Crane's, 212; Sons of Liberty, 204; Southern Guard, 204; University Volunteers, 146.

Monroe Hill, 194.

Mosby, John S., wounds Turpin, I64.

Observatory, 196.

Parsonage, 194.

Parthenon Literary Society, 248.

Patrick Henry Literary Society, 234, 237.

Pavilions, occupants, 290.

Philomathean Literary Society, 248.

Poe, Edgar Allen, 239, 273.

Presidency created for Wirt, IIo; Jefferson's dissent, 112; Wirt declines, II 3 ; advocated in 1846 by W. C. Rives, 162 ; sentiment for, 348; arguments for and against, 349.

Proctorship, proposed magisterial powers of assailed, 28.

Proctor's office, 293.

Professors, foreign, John Adams disapproves, 83 ; newspapers criticise, 83 ; General Blackburn defends, 84 ; reception in Richmond and at the University, 9I; first winter at the University, 93; not in touch with social customs, 171 .

Publications-Alumni Bulletin, 26o; Annals of Mathematics, 26o; College Topics, 259; Collegian, 254; Corks and Curls, 260; Jefferson 
Monument Magazine, 248; University Literary Magazine, 248, 258; Virginia Literary Museum, 254.

Rebellion of 1833, 143; 1836,147 ; 1845, 159; faculty appeals to civil authorities, 161 .

Religious life, 315, 370; optional attendance at chapel, 315; chaplain system, 316; list of chaplains, 370; general secretaryship established, 317; activities, 318 .

Restoration and expansion, 288; cost, 289-9o.

Rice, Dr., criticises the appointment of Cooper, 70; is defended, 71 ; his friendliness to the University, 71.

Rives Boat Club, 299.

Riot of 1825, 130; investigated by the Visitors, I32; students expelled, 133; Jefferson's answer to a student "paper," I 34 .

Rockfish Commission, 43; its problems, 44; bidding for the site, 46; members, 48; meeting, 48; declines to adjourn to Staunton or Lexington, 49; vote on the site, 49; the report in the legislature, 50 , et seq.

Rotunda, its model, dimensions, etc., 186; destroyed by fire, 280 ; restored, $286,287$.

Schele De Vere, Maximilian, 334, and note.

"School of Athens," 190; exhibited in Europe and America, 191.

Schools, 325; professorial accountability, 325; examinations, 325; evolution of, $33 \mathrm{r}$.

"Sons of Liberty," 204; uniform, 207; off to the war, 208; roster of officers and men, 211 .

Southall, Valentine W., 35; connection with the Simms hearing, 158. Squibb Gymnasium, 298, 30r.

"Southern Guard," 204; officers and privates, 205 .
Testimony on honor, 166; Visitors' resolution nullifies, I71-2; Jefferson's rule restored after one year, 173 .

Thornton, Dr. William, 177.

Ticknor, George, invited to become a professor, 74 ; sectarian distrust of his religious convictions, 75 . .

Track and field sports, with records, 302.

Tucker, George, elected professor of moral philosophy, 76; first chairman of the faculty, 94; resignation, ror.

University, provision for 42; contest over site, 48, et seq.; site adopted and the University chartered, 54 ; its architect and architecture, 181 .

University Literary Magazine, 248, 258; medalists, 258.

University Literary Society, 249.

University Volunteers, 146; rebel against faculty, 147; expulsion of seventy students followed by riots, 149; reinstatement of the expelled, $15 \mathrm{r}$.

\section{Virginia Literary Museum, 254.}

War, civil, Virginia alumni in, See Civil war.

Washington Literary Society, 245; badge, 247; officers, honor men, etc., 250; medalists, . etc., 365-7; ante-bellum notes from its $\mathrm{min}$ utes, 250; final presidents, 364 .

William and Mary College, proposal to remove to Richmond, 64 .

Wirt, William, offered professorship of law and presidency, 109, III; declines, $\mathrm{I1}_{3}$; advises the appointment of Lomax as professor of law, 114 .

Y. M. C. A. established, 318; presidents, $37 \mathrm{r}$.

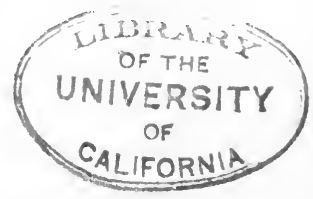





\section{RETURN CIRCULATION DEPARTMENT IO $\rightarrow 202$ Main Library}

LOAN PERIOD 12 HOME USE

4

ALL BOOKS MAY BE RECALLED AFTER 7 DAYS

1 -month loans may be renewed by calling 642.3405

6-month loans may be recharged by bringing books to Circulation Desk

Renewals and recharges may be made 4 days prior to due date

DUE AS STAMPED BELOW

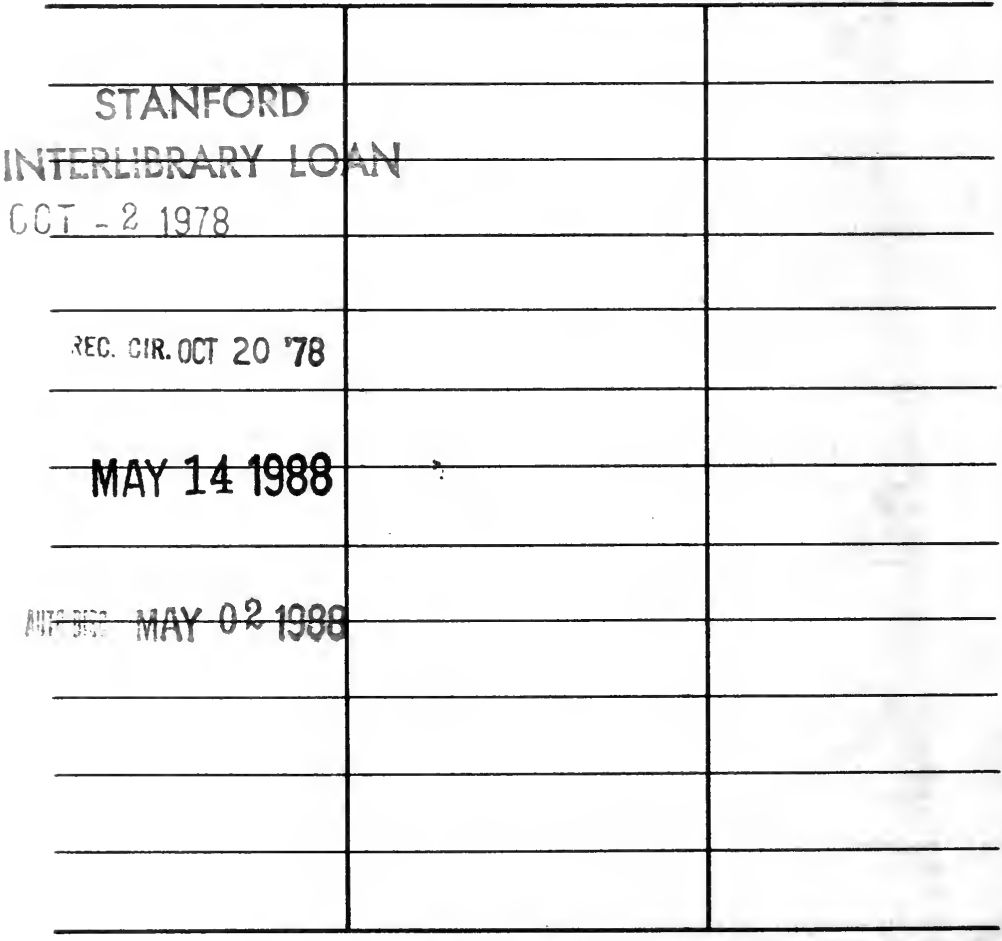

UNIVERSITY OF CALIFORNIA, BERKELEY FORM NO. DD6, $40 \mathrm{~m}, 3 / 78$ BERKELEY, CA 94720 
dalo a

Tso mm

YC 04861

U.C. BERKELEY LIBRARIES

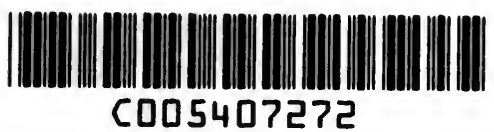

C005407272<smiles>C1CCCCC1</smiles>

:

Ne 
